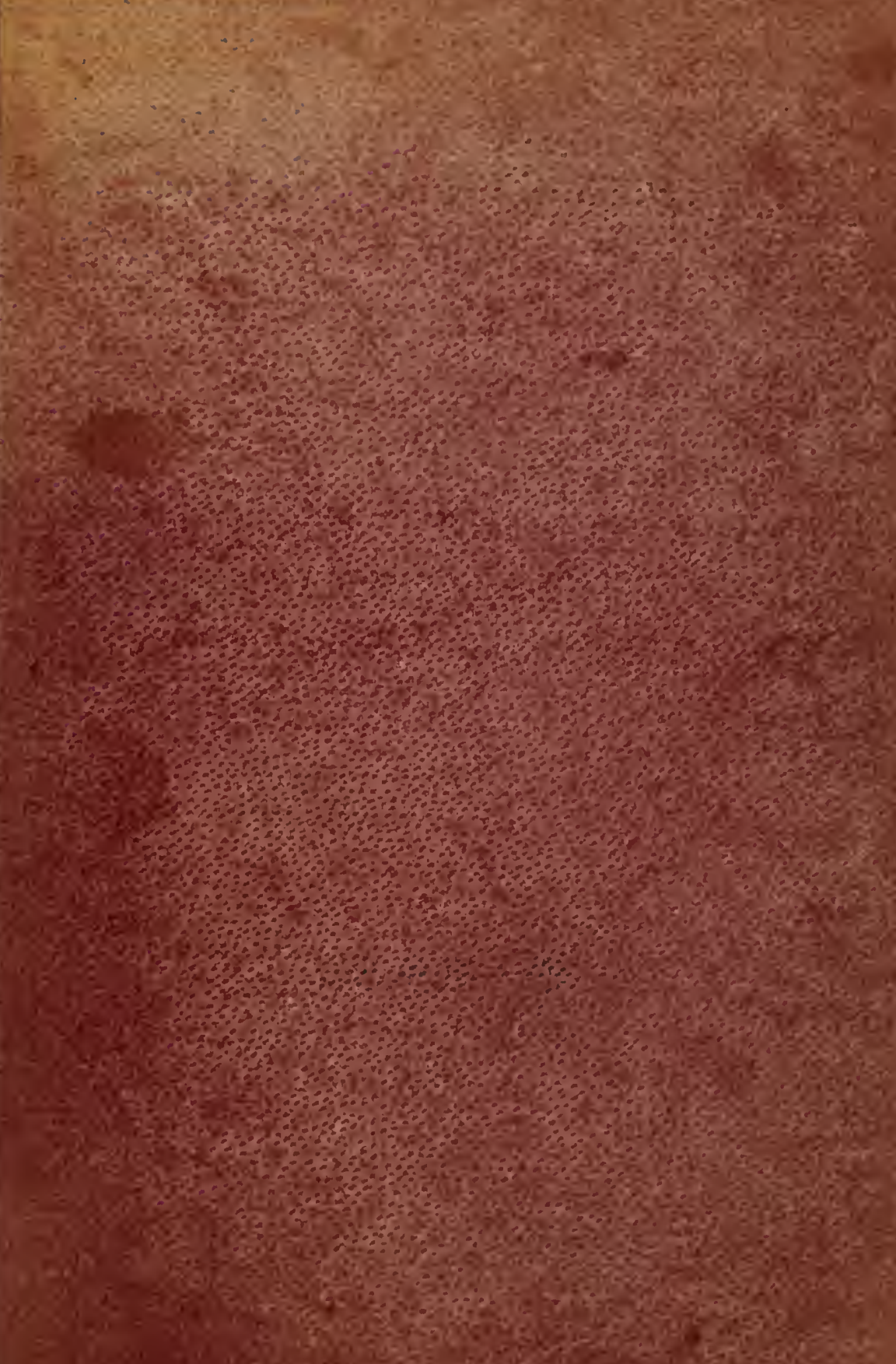




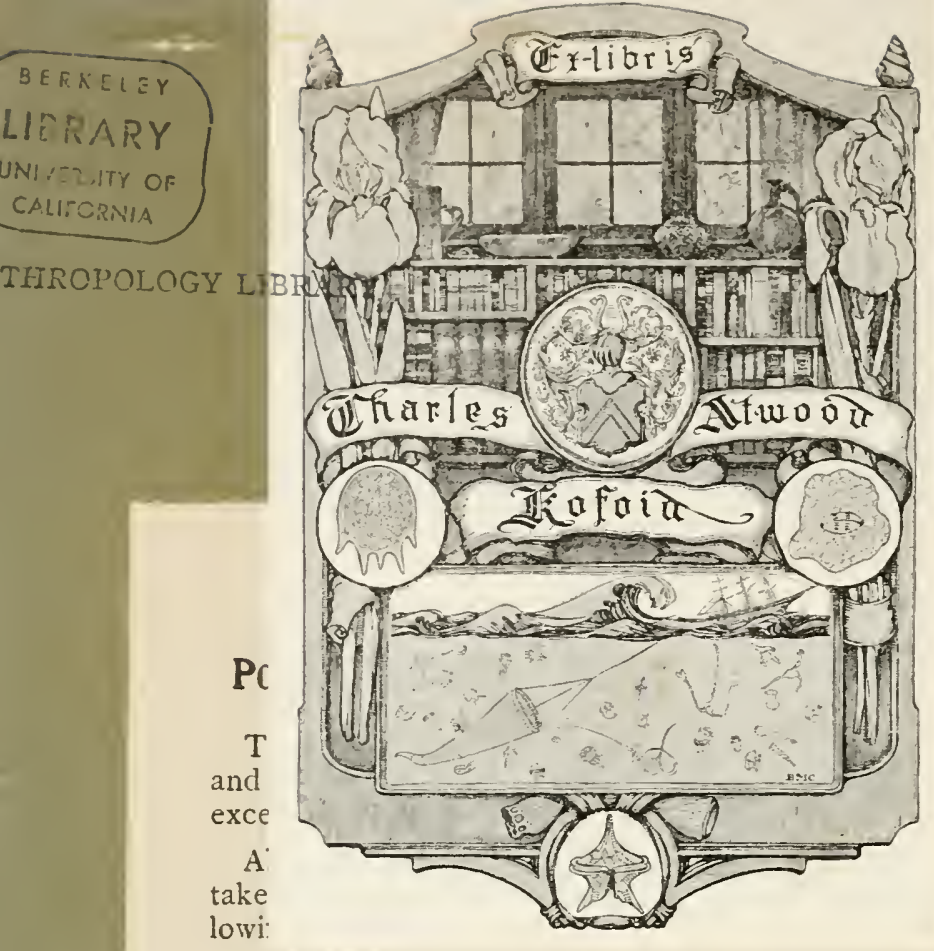

Any person residing temporarily in Machias may take books at the rate of 10 cents per week.

Non-residents at two dollars per year.

The time allowed for the retention of books shall be two weeks for each volume; but when any boc $k$ is in great demand, the time may be limited to "ne week, or less than one week.

No person receiving a book from the Library shall lend it to any one not a member of the same household.

Persons holding books beyond the specified time shall pay two cents for each day's detention; and if detained five days beyond the time specifierl, the book will be sent for and ten cents extra collected from the delinquent. No book shall be delivered to any person whose penalties remain unpairt. 


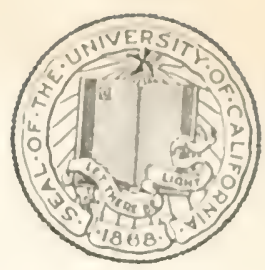

THE LIBRARY OF THE UNIVERSITY OF CALIFORNIA

\author{
PRESENTED BY
}

Doyan enom PROF. CHARLES A. KOFOID AND MRS. PRUDENCE W. KOFOID

$$
\begin{aligned}
& \text { (다네 } \\
& \text { Gedmant Oil. Giversm. } \\
& \text { Qpeceived fune 1, } 187 \% \text {. }
\end{aligned}
$$





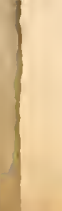





\section{THE SATURDAY LECTURES,}

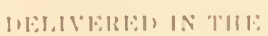

Lecture-Room of the U. S. National Musemm,

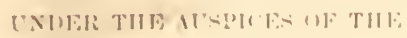

Anthropological and Biological Societies

OF WASHINGTON,

IN MAIRCI ANI) APRII. 188\%.

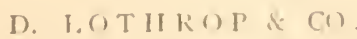

30. 32 FRANKIIN STREET, BUSTON, MASS

WASHINGTON, I), ( :

JUDD \& DETWEILER, PRINTERS ANI PUBLISHERS

1852. 



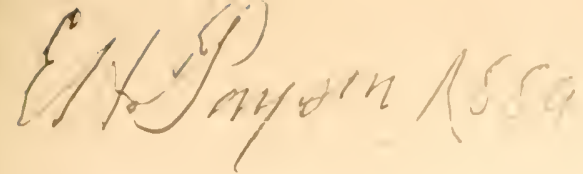

CONTENTS.

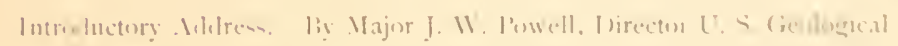

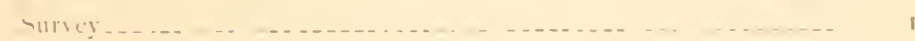

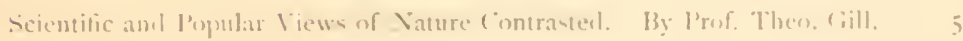

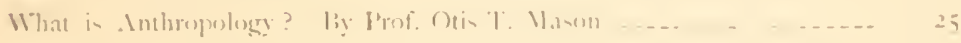

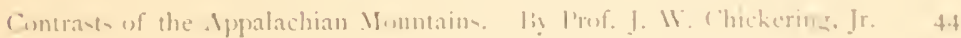

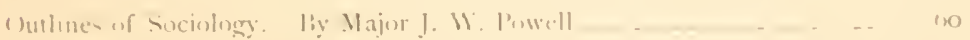

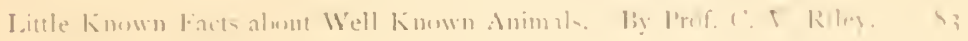

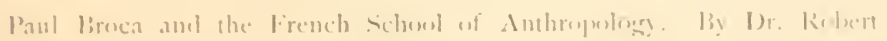

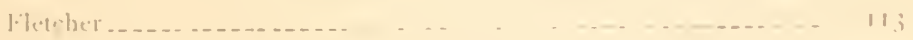

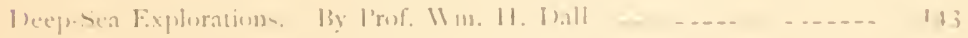

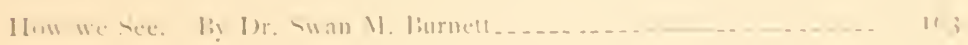

i11

$\bar{N}:=n 768$ 
Digitized by the Internet Archive in 2008 with funding from Microsoft Corporation 


\section{IN'T'RODUC'ORY ADI)RESS}

liy J. W. Powill.

Direclor, U. S. Geolegrical Surrey.

On the occasion of the delivery of the thrst of the Salurday lectures, the fot lowing remarks were made ly Major I. WV. PowktL:

For matuy years the General Govermment has been prosecuting scientific researeh through various agencies. The field of these investigations is wille.

For a long time geologicial surveys have existerl in various forms. In the sturly of the structure of the earth's crust-the mountain: and plains, the hills and valleys have been traversed, and rocks, minerals and tossils collected; and by these fossils we come to a knowledge of the way in which the ancient earth was clothed with vegetation, and of the animals that lived in the aneient seas, lakes, and rivers, aud roumed over the lands.

During all these yeals hiologists have been at work stulying the plants and animals that now live upon the earth and collecting biologie materials from every land.

During all these years anthropologists have hecu nt work studying the native races of Auerioa and enllecting their works of art.

since the foundation of the Sunthonian Institution, it also has in all these departments promoted research and eollected scientific materials for study, enlisting in its corps of collaborators men or every part of the United States-yes, of every laud and every clime.

Since the organization of the Fish Commission, the nations of the seats, and the tribes of the lakes and the rivers, have been stulied. Through these agencies, and yet many others, there has aceumulated in Washington, in the enstody of the sunthsonian Institution, a large body of material which has been the hasis of a vast system of scien. tifie researcli am publiention. The General Goverument is now annually publishing from 20 to 50 large volumes-the monographs and memoirs of seientific research-and the rate of publication is rapidly increasing.

These materials have already performed an importmut purposegreater than an be estimated, hut thair value is perennial. 
With every arlvance made in science the old material must be re-examined for new facts, and to discover new relations. In this manner all are to go on increasing in value from decade to decade with the advauce in human knowledge. In future years the scientifie men of the world must resort to the National Museum at Washington, to pursue or to complete their studies. It was, therefore, the part of wislom for the National Legislature to provide means for the preservation of this great collection, and to provide also, for its re-examination and increase.

These materials are not alone of interest to the scientific specialist. They have an interest and value to all intelligent people under whose eyes they fall-a value that depends largely on their orderly arrangement and classification; so that the great facts and principles of the many sciences represented, may be presented in birds-eye views to inquiring students.

Such are the functions of the National Museum, and the Institution is restined to exert an ever-increasing influence in the progress of science.

In order that all possible benefits may accrue from the enterprise it is proposed to establish a series of popular science lectures in this hall. Here, then, are presented the simpler lessons taught by the works of nature.

It is no easy task to explain the subject-matter of the various branches of science in such a manner that facts and principles may be easily grasped by those who are not specialists. A clear comprehension of any scientific subject is always accompanied by a power to clearly present the subject to scholars in the same department. A failure to present science to scientific men is fundamental evidence of failure in comprehension. But to present a scientific subject to those who are themselves not specialists or scholars in the specific department in such manner that they will be interested and instructed is no easy task. The man with this power, with this genius, is rare. He must be ready with illustration, apt in the selection of non-technical words, clear and forcible in his presentation, and especially must he be devoid of that pedantry which loves to revel in a wealth of details and technicalities, and he must so master his subject as to be thoroughly saturated with it. Then every word, every tone, and every gesture, will convey a thought.

The course is inaugurated this afternoon by a lecture on Scientific and Popular views of Nature Contrasted.

Since man first inhabiter the earth, two methods of thought have 


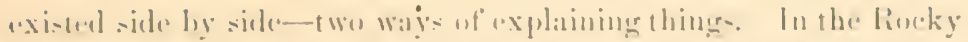
Momntaius you may hear an lublian explain the manhow with all its beatiful color as the serpent that almates the firmanenc of iene

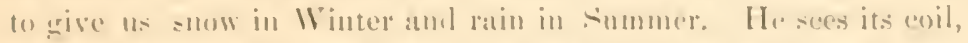

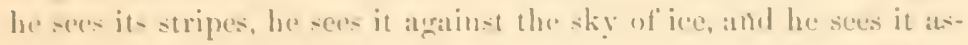
sociated wilh rain which falls from ahore, and so he calls it the Gireat serpent of the Storm. 'The methorl of thenght hy which he arrives at this conclusion is subjertive and - uperficial analogies are dred as

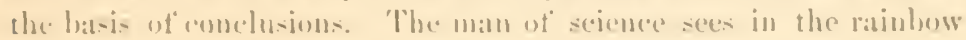
the analyzisof white lient inte its eon-tituent colors.

The metherl of thought is shjowtive, and erential homolugries are unel at the hasis of his (xplatuation. But these twe methods of

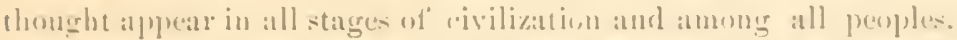

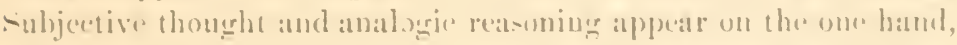
objertive thought amb homolegric reasoniug on the other : and it thes: happens that in all the domain of Sature there is a rast borly of

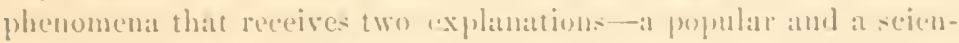
tific. But. gratually, the seientife metherl is besming the popmlar

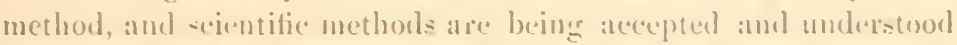
more and mure, as the years pass, he the intellitent people of civilization; and it is the purpose of the lectures inangurated this laty

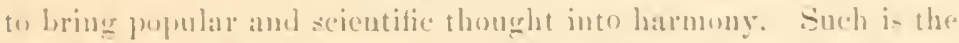

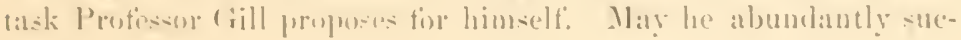
ceed.

Ladiies and gentemen: I have the honor to present the learued and eloquent lecturer, Protes=or rill. 



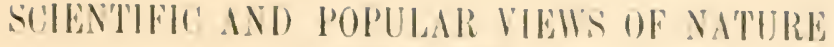 CONTRAS'TED.}

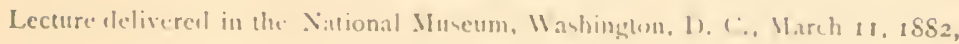
hy I'rof. Tirro. Gillt.

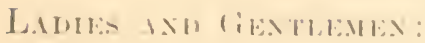

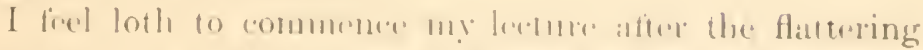

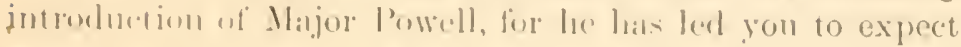
more that you will receive, and to believe that what you

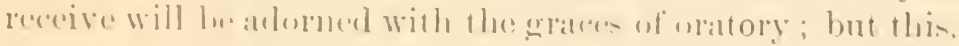

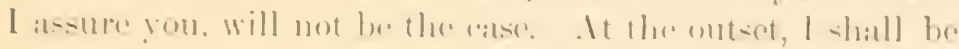

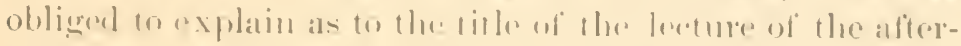

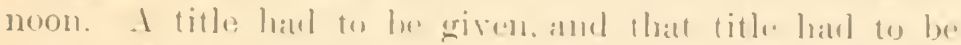

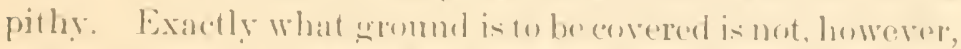

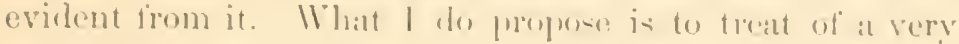

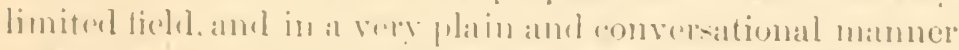

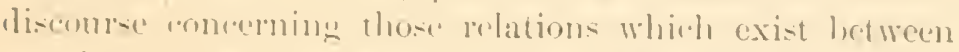
artain womps of animals, and the opposite phases moler which they arrentromplated hy the seientifir mind on the

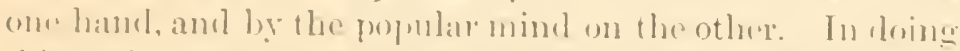
this I shall take roncrete examples, and, after ansillering

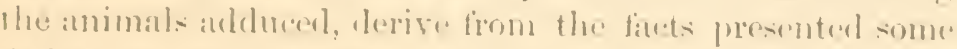

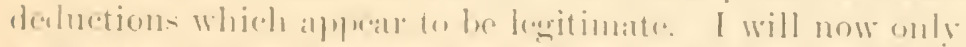

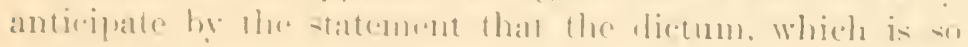

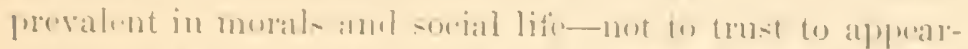

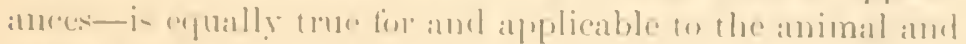

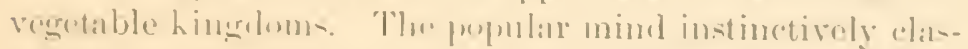

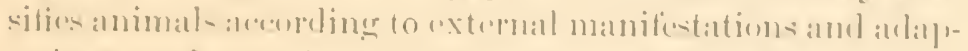

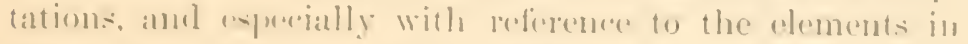

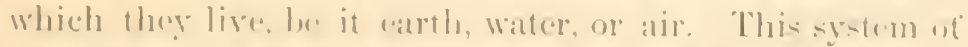

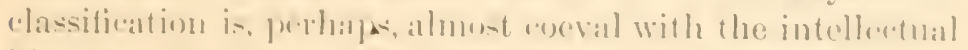

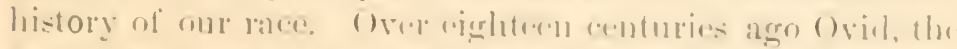
latin poet, gave (xples-ion to such irlats in the first lusk

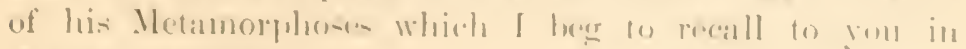
Dryelen's version:

. Hefore the seas ant chi- terre-trial 1.11.

Inel heaven'- hight canopy that corer all. Gue was the face of nature: if a kece:

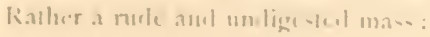


No sum was highted up the world to view, No moon did yet her blunterl hours renew, Nor yet was earth suspended in the sky, Nor poised. did on her own foundation lie. Nor seas about the shores their arms had thrown but earth, and air, and water were in one. Thus air was roid of light. and earth unstable, And water's dark aby'ss unnavigable.

No certain form on: any was impressid: All were confusion, and each disturb'd the rest. For hot and cold were in one body fix'd, And soft with hard, and light with beavy, mix'd Thus disembroil'd, they take their proper place : The next of kin contiguously embrace; And foes are sumder d by a larger space. The force of fire ascended first on hight. And took its dwelling in the vaulted sky : Then air succeeds, in lightness next to fire,

Whose atoms from unactive earth retire. "*

As to the mode in which the various elements were peopled, hear also Ovid:

" Then, every void of uature to supply,

With forms of Gods he fills the vacant sky;

New herds of beast he sends the plains to share;

New colonies of bircls to people air ;

And to their oozy beds the finny fish repair.

A creature of a more exalted kind

Was wanting yet, and then was man designed."

In such worls the great poet las imborlied the popular conception of the divisions of nature and of the relations thereto of the animals which people the world-one set for the earth, a different creation for the land. and a third for the air. These views, or some not exentially differing, were current until within a comparatively recent period.

It is easy by a merely superficial examination to convince

* Ante mare et tellus, et, quor tegit omnia, colım,

Unus erat toto.naturge vultus in orbe,

Quem dixere Chaos; rudis indigestaque moles;

Hane Deus et melior litem natura diremit:

Nam ealo tcrras, et terris abseidit wndas ;

Neu regio foret ulla suis animantibus orba;

Astra tenent caleste solum, formseque deorum;

Cesserunt nitidis habitandie piscibus unda:

Terra feras cepit; volucres agitabilis aër. 
ourselves that this tripartite division of animal life is very incorrect. We sce prominent ahout us, it is true, cortain animals that seem especially adapted to specilie olementsthe quadruperls for the land, the birds for the air, and fishes for the water; hut ats soon as we proceed to at morre detaited review, and attempt to collocate with them the other animals that live on the earth we come-njon stmublingr-lilocks in every direction and are suon forcer] to modify and change our ideas. Without taking into account the hosts of lower animals, naturalists soon reconnized that even the vertebrates could not be combinal uneler the tripartite division. linnatus arave the name Amphibia to those forms intermediate between the lanel animals and the water animals, including the reptiles and hatradelians-frogs, salimanters, de. But it was not till a long time afterwards that even Linnetu- became convincerl that this was not going fur enough. Only in the later editions of his work published towiurd the end of his life lid he teach that animals must needs be regrouperl, and in a manner that would be foreign to popular opinion. He first clearly recognized that whales were not fishes, bent esentially agreed with the viviparous hairy quadruperts, atul under the name of Mammalia hr first combined the two type in one class. I presume that the majol fortion of my aurience reconguize in a sort of way the fact that whales are not fishes, but mammals, or animals, as must preople pleatere to call them. At the same time there is a fear that many accept the dictum withont undertameling the why and wherefore ther an so ensiclcret. It will, therefore, be ny task this atternoon to grive some of the reasons why the whales are not regrarled ats fishes, and why they ane endsilered to be mammals. Afterwarks it will appear that, hy parity of reasoning, there will flow a serice of heduction-, ayplicable not only to the forms about to be treated of, but also to animated nature generally.

I loubt not that if the puestion "are whales ti-hes?" ware put to popular vote, there would be an overwhelming assent to the ancient belief. Indeal the proposition that such is the ease has been sanctioned hy that "bulwark of 
our institutions"-a jury in a court of law. About sixty years ago, a case was brought up in the New York courts, involving that question. It was a revenue case, and the suitor was one Maurice Judd. It was decided with all the formality of law that the whale was a fish! Times and ideas have changed since then, but not so much as to forbid us to believe that essentially the same views are prevalent. at the present day, and I presume that the old verdict expressed the opinion of the majority of mankind at this time. Indeed, it may seem presumptuous in me to differ from such high authority as a court of law.

But without further preface, I shall now invite your consideration of the skeletons at my sicle, one of a porpoise, which is simply a kind of a whale, and the other of a swordfish, which is a true fish. I will contrast the differcnces between the two; first, as they appear in the flesh, and then those which become manifest on dissection.

As to form: of course, superficially there is a great deal of resemblance between a whale and an ordinary fish, and it is this superficial resemblance which has impressed upon the popular mind the idea that the whale is a fish. But, even if we consider only this external form closely, we find that material differences occur, and those differences are the indieations of very much greater dissimilarity of anatomical structure. In the fish, the tail, you will see, is vertical; in the cetaceans it is horizontal.

In the skeleton of the fish, the tail is composed of many bones diverging from the tail rertebræ, and forming a framework for the rertical fin. The fish in its progress through the water moves this fin to and fro, sideways. In the skeleton of the cetacean, there are no bones in the tail, but the rertebre taper backward, and have nothing comparable to the bones of the fish. The fin is represented simply by a mass of fibrous tissue and muscles, and it is inserted lorizontally, so that the animal, in progressing, propels its tail upward and downward.

These are the indices of very important differences. The whale's tail is not at all like the fish's tail. The latter is a 
peculiar organ, inserted at the end of the vertebat column, and has a frame work of hones, developed around the last vertebra, and alpended to thrm.

Before proceding further in discuses the rhatracture of the: caudal fin of a whale, let me eall your attention to the fins which are developerd moler the belly or midille of the benty in the arp and trout, and atthough alseme in the swordfish, in orlinary fishes present. You will fimd nothing worresponding to these in position in the whales, but I will now attempt to show that these fins, which are called rentral fins, inserted under the back, far forwad, are represented by the flukes of the tail of the whale, whinh mut, thereform. be entircly diflerent from the tail of at trur fish. But how can thic be"

You are all andpianted witl the oxternal appearame of the seal, in which the posterior feet are nhwiously present, but are thrown far backwarl, amb a ro to a great extent horizontal berond the holy. Now. imagine these fins flippers, we feet, whatever you may call them, with the bones atrophicel, or

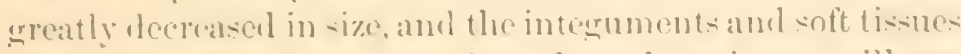

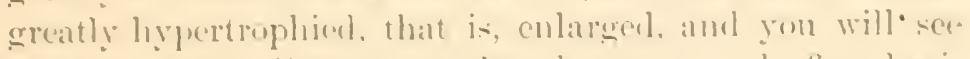

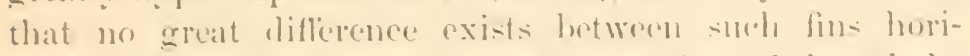
zontally extended hackward, and the flukes of the whale. In fact, it is known, not wnly from anatuminal, hut firm embryological and paleontologieal datal, that the tail of at whale is escentially the rent of an exces-ive derelopment of the intermments strromoling the posterior feet, and the atrophy, or diminution of, or even in some ases the entire los: of the posterint limbs, so fur an the bones alde conecrued. But the bones of the posterior limbs are not absent, or ren insignificant, in all spereses of whales. In the right whale (that whence the whalchone is derived) we have not only the pelvic or haunch hones, but also the proximal bones-those next to the pelvic-aleveloperl; that is, we have not only the bones representing thoe which anstitute the pelvis in man. but we also have other benes connerterl with these bones which represent the fernur or thigh bone, and the sulecenting or leg bones. Those bones are developed still more in 
certain forms that are in some measure intermediate between the cotaceous and ordinary quadrupeds; that is, in extinct forms known under the name of Zeuglodonts which have not existed since the eocene epoch, and in ancient forms of the group, (Sirenians,) to which the Nanuatee, and the Dugong of the present time belong.

Reverting now to the rentral fins of the fishes, you will perceive that they correspond in position with the hind legs of tadpoles. If we compare the rentral fins of certain fishes of a rery generalized kind, as it is called-that is, like those forms from which other fishes and amphibians are supposed to have alike descended-with certain extinct amphibians, also of a generalized kind we are prepared to recognize a similarity, and ultimately an equivalency of those rentral fins with the hind fect of quadrupeds. (The equivalency; let me state here, is called homology.) The so-called gencralized fish which is most instructive in its indications is the Polypterus, (there is no common English name,) of the Nile, and other African rivers. The generalized amphibians are known as Labyrinthodonts, etc.

You will, I think, have no hesitation in recognizing the expanded rertical membrane of the tail of the tadpole as equiralent, so far as use is concerned, at least, with the tail or caudal fin of the fish. Let me further direct your attention to the fact, that the fish's tail and the tadpole's tail is median as well as rertical. If you are now prepared to concede all the propositions enunciated, you will be prepared likewise to give assent to the proposition, that the whale's flukes in horizontal position, and in being paired, are more like the seal's flippers, and therefore comparable with the lind limbs; and therefore unlike the tail of a fish. Inasmuch, further, as the seal's flippers are modified hind legs, and the ventral fins are also representatives of the hind legs, the whale's flukes are also modified hind limbs, and therefore the flukes and the rentral fins are equivalent, in a homological sense, to each other.

But low about the fore fins or pectoral feet? Are not they much alike in whales and true fishes? 
Externally, the pertoral fins lo look at fibe sight rery much alike, but you will on looking eluser perecive that ats in the tail lin, the tistis pectoral has rays visilde extermally

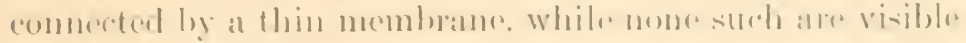

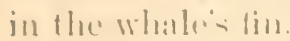

()n taking the Hesh from these pestomat lim-, and laying bate the hous, you will at oner porecive how utterly molike

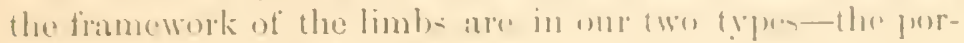
poise and the sllorelfi-li.

In the genproise wo hase not the latst diflicully in alt omer rerogniming the bones rorrepombling to the linger

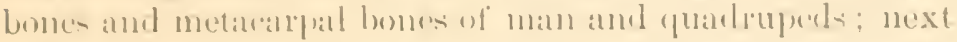
we als plainly lones: then there alle two hones evidently ampallable with

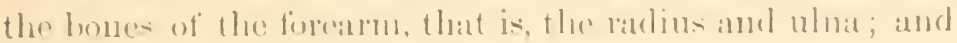
finally. next to the borly. Wo see at single bone which is

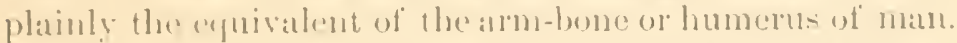
Commected with the alm we find a wille flat bone aloove,

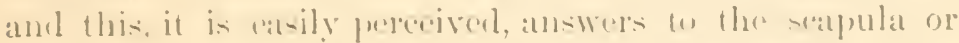
shoulder blade. Culike thron as the pectoral lin of at

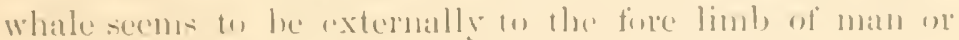

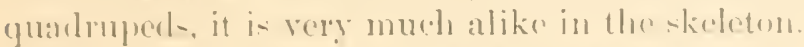

Now, lut us turn to the tish's pectoral fin and its monec-

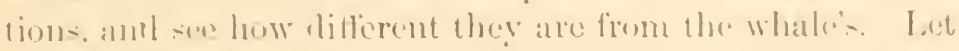

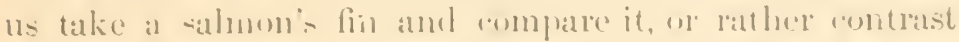
it with the whales. In the salmon, fim firom timbling aroat

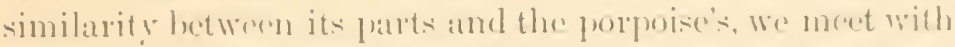

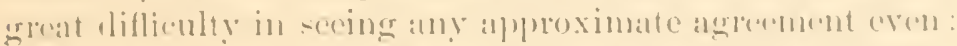

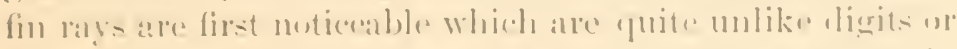

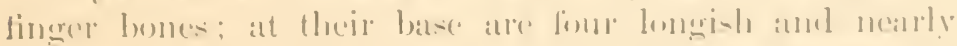

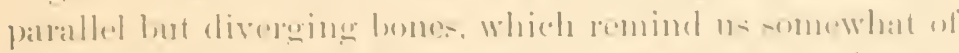

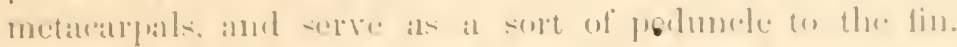

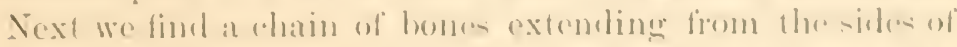

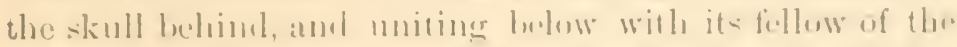

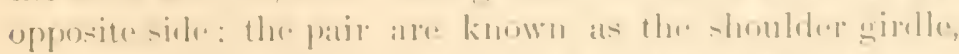

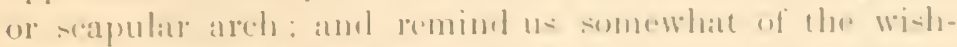

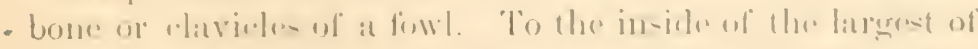

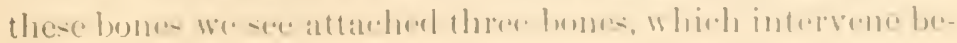


tween it and the yuasi-pedunculated fin. What are these, and how are they comparable with the anterior members and appendages of a whale? I am eompelled to admit at once that we cannot compare them directly, and if we attempted to doso, we would almost inevitably fall into gross error; indeed, the old anatomists who marle the attempt did so. Men, illustrious in science, like Cuvier, Agassiz, and Owen, ronsidered the fonr longish bones we have noticed as carpals, and the two externally flattish bones which support them as the radlus and ulna. To ascertain their true nature, we have to avail ourselves of extraneous evidence. I am, therefore, compelled, in justice to you as well as to myself, to make a slight digression.

Let us now examine for a moment the skeleton of polypterus, to which we have before reforred.

The pectoral fin of polypterus has rays which are essentially similar to those of the salmon, and at the base of those rays are a number of nearly parallel longish bones which rescmble the four at the base of the rays in the salmon. In polypterus we also find a shonlder girdle which is not unlike that of the trout. But now please direct your attention to the inner side of the principal bone of that girdle and instead of three bones, as in the salmon, you will find there is a single large piece; that piece has a peculiar kind of projection which is divided by a partial constriction from the body of the bone and reminds one of a ball. Articulating with this are two long diverging processes. Between these processes is to be especially observed a flat cartilaginous mass which also intervenes between them and the parallel longish bones.

To understand the structure thus revealed, examine now the pectoral fin and shoulder girdle of the common gar-pike of the Potomae river-the lepidosteus osseus of naturalists. The fin has rays like those of the polypterus and salmon; it has also the longish bones at the base. The shoulder girdle is developed as in them, but with special characters of its own. But the inner piece attached to the chief bone of the girdle is especially noteworthy. As in the polypterus, it is 
single, lut it otherwise resembles the than bones andsined of the salmon, and the there elements of that type evitently are the disintmerated representatives of the solid artilage of

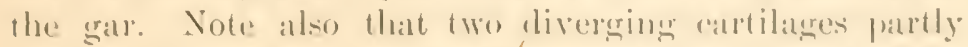
bound and partly intervene betwen the hatsil bones and the

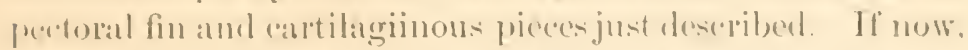
timn and the merasm permitted. I might submit to you

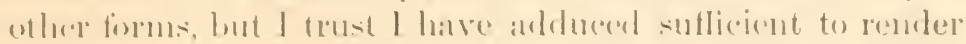

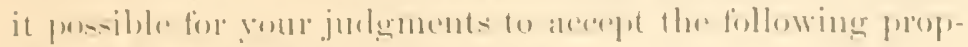
usitions as at leas not improbahla.

The pertoral fin and stlstaining anch of the fishes in its sorelal clements are referable to two categories.

The rays, the longi-h bones at their bases, and the bones

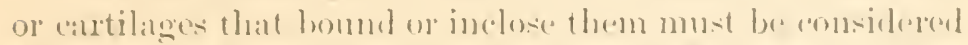

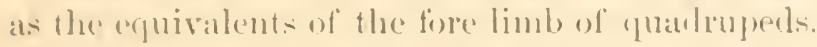

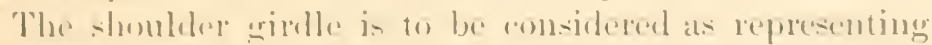
the seapula of land animals. but with cortain additions.

The projocting ball-like tuberele of polypterms is of es- pectial signilicance.

l.ook. mw, at the peretoral lin of polypterus, and compare it with the fore limb of a quadruped: you call alpereciate some wamblame, I think, between (1) the divereng pro-

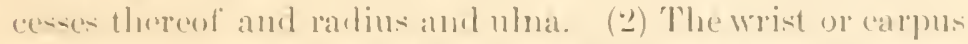

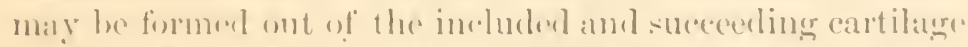
of polynterus. (3) The metacarpals are at least simulated

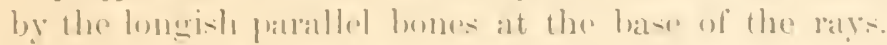
The phalanges may be represented by the peetoral rays. The homerus is still to be anomuted for', and I am inclined to believe that it is represented by the constrieted probucke that support the fir-t named boncs. Ithether the redations

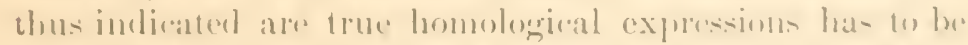
still proverd, but they are, I venture to think, probahla. But the rery doubt still involving the punstion is, at least,

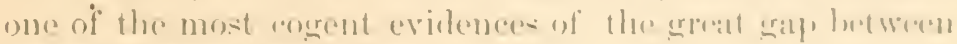
the whales and the tisles.

If I am right in the conjectures thus ahdured you will now sec that while the fore limb, bone for bone, is the satue in the whale as in the quatruperl, it is anly partially mpre- 
sented in the fish, the digits being puobibly, but only very distantly, repeated in the salmon by the rays, and the metacarpals by the bones at the base thereof; the bones of the arm-the radius and ulna as well as humerus-are entirely wanting. 'The single scapular or blade bone of the whale, on the other hand, is represented by at least four pieces, and comnected with the arch of the fish are several other and accessory pieces.

I have thus dwelt upon the fins becanse if any part in the whale would show fish-like modifications, these parts would, from their relations to the surrounding medium, be naturally most liable to exhibit such adaptation. Upon the other points in the structure of the two types we cannot delay so long.

The shoulcer girdle, as we have seen, is connecterl with the skull in the fishes, and let us take up the consideration of that next.

Look first at the whale's skeleton; note that the skull, as . in man's, is one compact mass, composed of many bones, but all closely connected with their neighbors save the lower jaw. The lower jaw is directly articulated with the skull, and it is also especially to be noticed that its branches are undivided or single bones. Let me add as an item of information which I must ask you to take on trust that there are ear bones which, though much modified, agree essentially with those of quadrupeds.

Turn now to the fish's skull; you will at once perceive that the skull, contrasted with the mammal's, is much broken up. It has a brain box, but that loes not at all represent the entire skull of the mammals. The upper jaw bones, the palate bones, and others, are separate. The lower jaw has each of its branches composed of four separable elements, and those branches, you will see, have no direct connection with the brain-box, but are separated by the intervention of a chain of large bones which are not to be seen at all in the whale's skull. But, nevertheless, those bones are represented in the whale's head, and the bones forming the suspensorium, as it is cailed, of the lower jaw have their repre- 


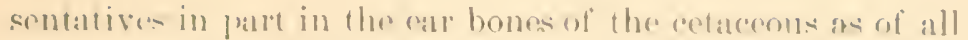
other manmals.

Thus we lind thr sime bones subserviunt to very diflerrut functions in the two types: in the mammal to hearing : in

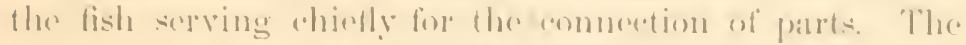
statement may evolir your skepticism. Int I mus- alk vou to accept it on tru-1, fin time will not allow me fo drmon-

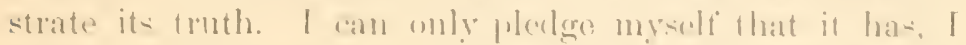
think, been elearly demon-trated that sleh is the atse hy

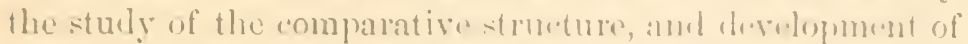
many forms, and by the collation of datal derives from various trpes com-ecutively ansideresl.

Commenterl with the skull vou will jererveremain other bones or appendanes. In the cefacean you may - we pendant from the -kull the articulation for the lowre jas, an apjareatus rompused of thres bones on each siele ennected by al central one. remineling one somewhat of a pair of hooksor a earel-rack. These bomes are known as the hyoid. In tho fi-h rou will of eourse at onee recognize the gills, which are on four arches on cach sirle, but observe also another arch in front, anel which performs the function of sustaining a nembranc attached to the gill covers. Further uberve that all the-c arches arico from a melian row of homes to which the tonerue is attalehed in front. Let me recall now

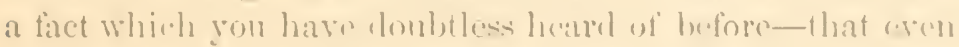
man as well as all other mammals have rillets in the lectal stage of life, and of sur.h gills the hroirl hours are the morlified restiges and reminders, and they roughly represent the

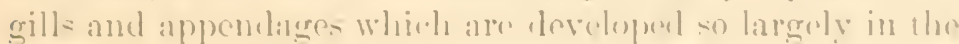
fishes.

Pleate direct vour attent inn now to thr oreans which -erve for the acration of the blond in the retacean, and to that whin correponds in the fish. You will motive that in the loremer there aro lung- on catele -ille, as well developed anel as obvious y lunelike as those of matn, amb that they alle connected with the moull by a tracheal tube which has anteriorly a thyroid apparatus, also as in man. On the other hand in the salmon there is nothing like a lumge but in its 
place you will see an unpaired membranaceous air bladder, which is connected by a simple, narrow tube with the csophagus, and in the swordfish, the tube, even, is entirely wanting, and the air bladder is shut off from communication with the mouth, direct or indirect. Nevertheless, did time permit, I could casily convince you that the lungs and air bladder sraduate into each other, and that the two truly represent, ${ }^{1}{ }^{2}$, in the language of the anatomist, are homologus with each other. On the one hand, our common gar has an air bladder so cellular as to be somewhat lung-like; polypterus has a still more lung-like bladder, and its relation to the intestinal canal, also approximates that of a lung; next a remarkable fish of Australia, named ceratodus, has what may more properly be called lungs than air bladder, and related forms of South $A$ merica and $A$ frica, known as Lepidosirenids, have as true lungs as amphibians. On the other hand, the amphibians, reptiles, and mammals show a gradation from the simple to the complex form manifest in the last.

Thus it will be apparent that the respiration of fishes and whales are effected by entirely different organs, and that the same organs may be modified and adapted for very different purposes. Nature is economical of her material, but most ingenious and versatile in the use of it, and employs the same stuff in inany ways.

In connection with the respiratory apparatus we very naturally consider the heart, which receives the blood which has coursed throngh the body, and sends it to be purified and aerated by the respiratory process.

In the whale, the heart is partitioned into four cavities or chambers-a right auricle and a ventricle, and a left auricle and a ventricle-as in man. The riglit auricle receives the blood which has circulated through the veins, and the right ventricle transmits it to the lungs where it is oxygenated and thence goes bright and purified to the left auricle, and by the left ventricle is transmitted to a gain course through the vessels of the body. In the fish, the heart has only two chambers; an auricle collects the blood that 


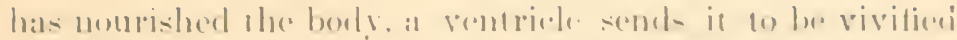
be the oxyeren in the watter, which moi-tent the grill filat-

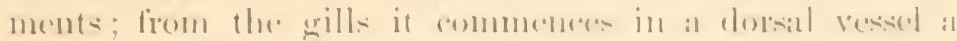

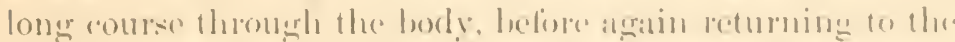

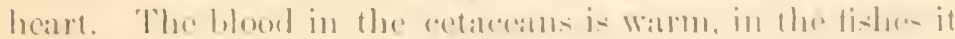

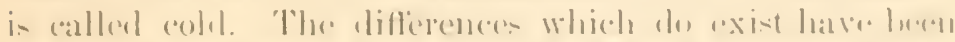

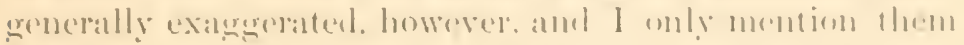

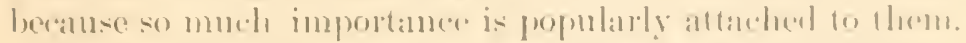

The impertant organs we have been latst eonsideringthe heart and the lumg-are inclesed in a -peecial ravity af

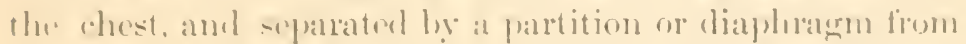
the other viserat, alike in the whates and other matmmals

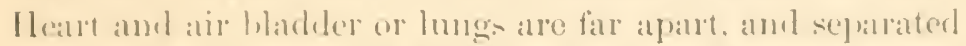
br-not from-other visera in the fishes and there is noth-

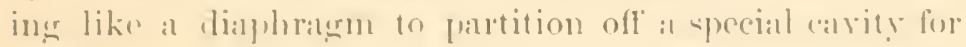
them.

Wo will next ronsider the hrabe of a whale amd of a fish. They are entirely dissimilar. The hrain of a whale is essentially the same as that of a matn, and extremely diflerent from that of a tixh. I whibit the brains of at porpoise and a mant. and rou cann eontrats theme with the enlarged figure of the brain of a salmon.

These illustrations will give an allerpuate inleab-at leaset so fur as we are all preacht coneerned-ol the structure of all hrains in the two widely -eparated rasses emprising man and the whales on we hambl, and the fishes on the othere

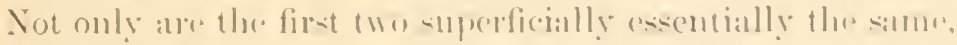

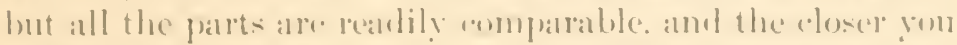
rximine the more yon will be struck by the similarity

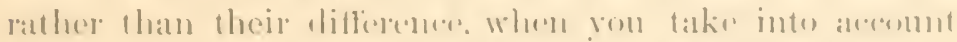

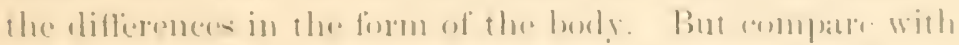

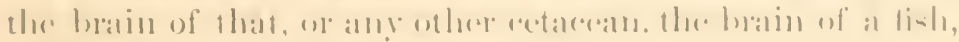
amel the diflerence alle rery marked.

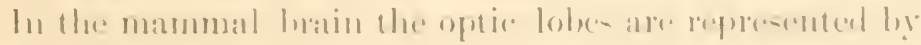

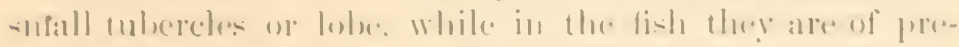

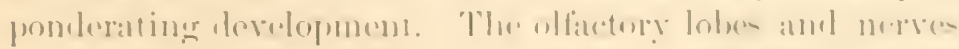

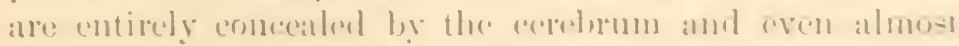

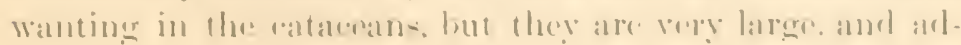


vanced forwards in the fish. The cerebellum of the fish and cetacean have an entirely different structure, and as to differences of detail, they are innumerab]e.

Those parts which are concerned in the reproduction and perpetuation of the species, are equally noteworthy on account of the close resemblance between such parts in the whales and in viviparous quadrupeds on the one hand, and on the other, the differences from fish's. Their characteristics, however, we must pass over. Suflice it to say, that as in man, the whales are viviparous, and the young are nourished by milk secreted by the mother. But it is proper to add that such characteristics are of less importance than many others connected with the organs of reproduction.

Many fishes are also viviparous. Viviparity or oviparity is of minor value. It is the mode in which the eggs and young are reveloped that is most significant for the two classes.

'Thus have we gone over the various parts of the economy of the whale and the fish, and in every case we have seen that the structure of the whale and man is very much alike, and that of the fishes very different.

If this superficial examination may be sufficient to sonvince us of the similarity of the whale and all other inammals, a inore detailed examination would simply add force, and the cogency of cumulative evidence to the argument, and would still more impel belief.

Let us now take into consideration another set of facts. There are certain forms known as marsupials, represented in this country by the opossum. In A ustralia that order is largely dereloped, and is manifested in a number of different forms. There are, for example, species very much like wolves, others like mice, and they are so called by the Australian colonists. Now, if we considered simply external form, we should be compelled to separate those species from each other, and refer them to widely different groups. For example, we should have to take the mice-like marsupials, and approximate them to the true rats and mice, and the 'Tasmanian wolf' we would have to approximate to the gen- 


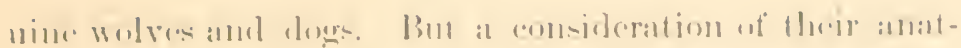

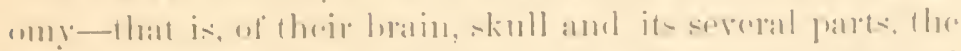

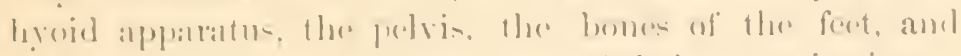

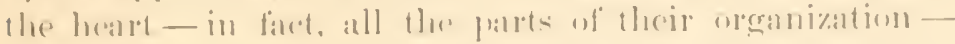

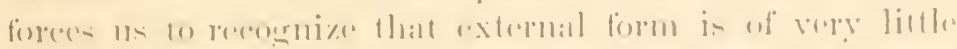

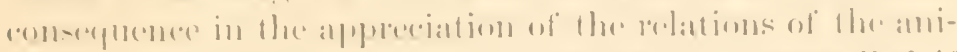

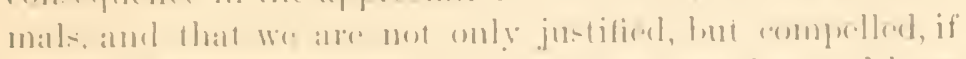

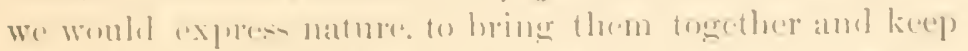

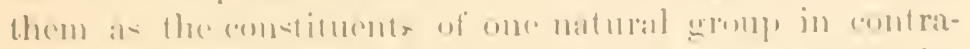

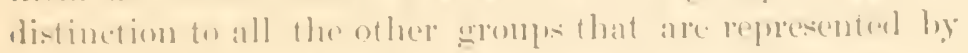

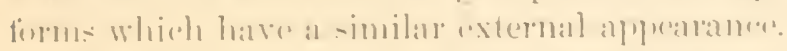

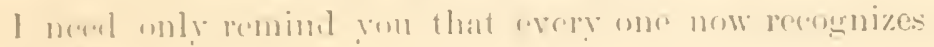
lhe lalt: as animals.

In hrixf. then. mammals may br deareibul at amimals whede have no gill- Wheh liveathe he means of luness, have a qualeilocular heart. - meling the blond to the

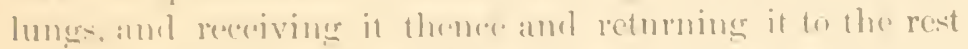

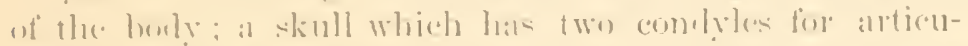
lation with the verlelual renlumm ame which has all its

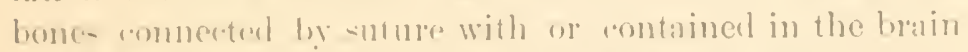
ase. cxerpt the lower jaw : and the lower jaw itself is anmprised of simple bramehe which articulate rimetly wath

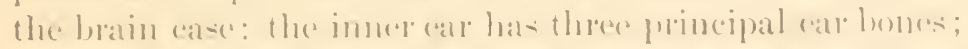

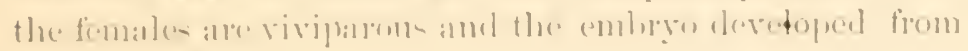
a viry-mall

In contlast, fishe- atu be challatcterized as animals whir.h

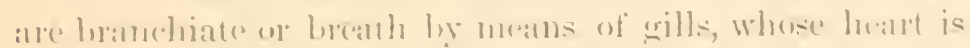

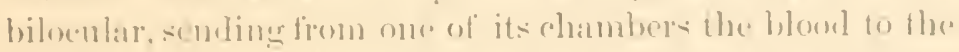

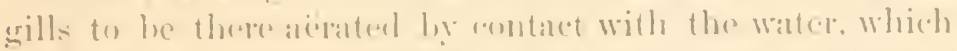
remtains oxyent and thenee to the remaining pertinn- of

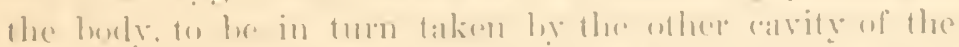

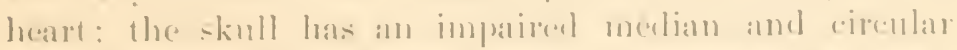

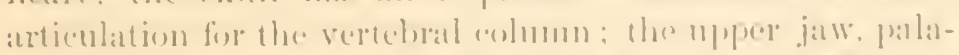

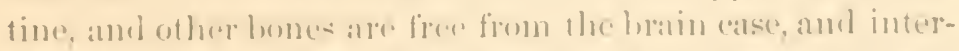
rening betwe(n) it amel the lower jaw is a slspentorinm of

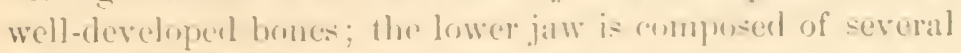

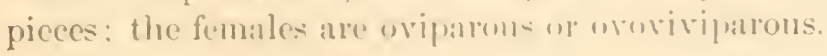


Such are, in brief, a few of the distinctions between fishes and mammals.

The class of manmmals contains forms fitted for progression on land, as bipeds (man) and quadrupeds; for flight in the air, as bats; and for exchusive life in the water, as whales.

The class of fishes comprises not only animals with the lswal fish-like form exemplified in the salmon and perch, but broad flattened fishes like the angler or goose-fish, and others of snake-like form as the eels.

Mere form, then, is of no consequence in the determination of the major relations of amimals and is of importance only in ascertaining the relations of minor gromps. Every type of nature which we examine brings to us evidence of the truth of this proposition. Animals which have the greatest external resemblance may be, when anatomieally considered, most unlike, and vice-versa, animals which are very different in external appearance, may exhibit great similarity in internal structure. I might adduce very numerous illustrations of the prevalence of this truth, but the advaneing monents warn me that I must bring my remarks to a termination. I shall, therefore, conclude with certain deductions that are to be derived from the studies in which we lave been engaged, and justify the title which I have selected for the discourse, by a contrast of the methods involved in the elassification of the animals we have been eximining.

The uninstrueted obscrver instinctively considers animals with regard to their external form.

The naturalist has learned to distrust external form, and to consider internal strueture as paramount.

The ordinary observer regards as of great moment the relation of an animal to its snrroundings and mode of progress-whether in land, in water, or through air.

The zoologist has learned that the adaptations for different modes of life may coexist with slight differenees in the internal economy. 


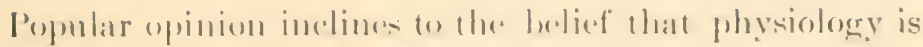
the best gudde to the elassilication of andimals.

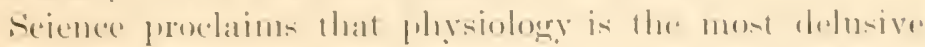

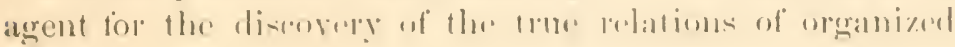
beilins:

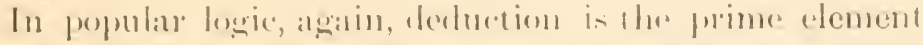
involvel. It is assmmed that reltain thing- alle, ambl form

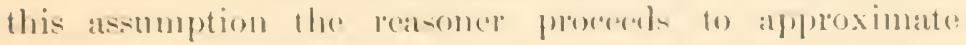
sucessively and without sufliedent leasum. the torms thal are presented for examination.

In science, on the other hand, it is imlurtion which is principally cmployed in mental processes for example, we

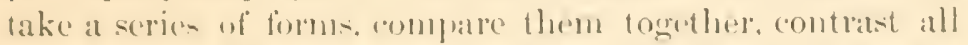
the elements of the sovelal parts, and are gruided by the letailed commlative (virlence of the marshalled facts.

The people nse a $110 m$ menclature based on aclaptations of parts for similat purposes, as the feet for walking, the wings for flight. the tins for swimming.

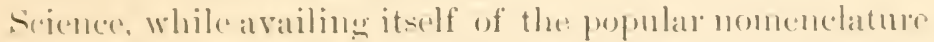
to expless one class of relationship-analogies-is compolled

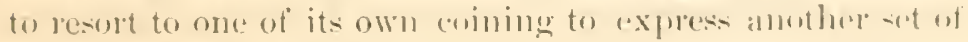
relationships-homologies.

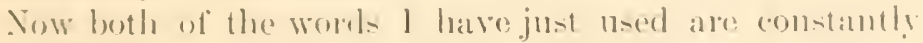
employal in seicutific works, amb all of yom who hare read such to any rextent must hase often colne across them. lint

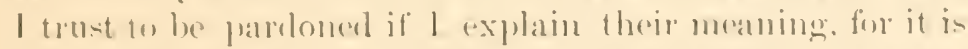
imposible to berin to molestame the problems of biologrs unless their -iendification is clearly apjechended.

Analogy is the andaptation of parts to similar functions but

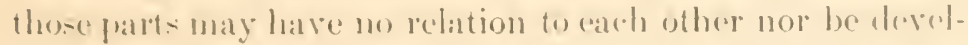
opeel fiom lles same farts of the boty. The rills of the fish

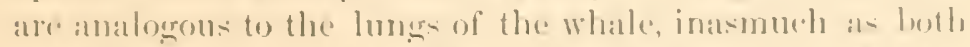
are subservient to the oflice of respilation; hat they are not homolerour. The tail fin of the lish and the tail fin of the whald alle also analogent-, but they are not homologrous.

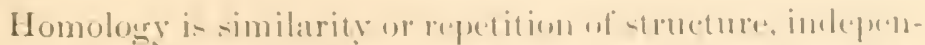
dent of the use of the parts. The remtral tios of the fists. 
the posterior limbs of ordinary quatlupeds, the logs of the human subject, the hind flippers of seals, and the caudal or tail fin of the whale are homologous. Several of the bones of the suspensorium of the lower jaw of the fishes and the uar bones of man are also homologous, although, be it remembered, they have no functions corresponding, being in that respect entirely dissimilar. I'et, again, homology is seen in the air-bladder of the fish and lungs of mammals; and, further, in the gills and branchiostegal bones of fish and the hyoid apparatus of man and other mammals. In all cases their functions are very dissimilar.

But do not infer that there is any necessary contrast between analogy and homology. Of course those parts which are formed of the same elements, and have the same functions, are both homologous and analogous.

It is by a strict attention to the prineiples thus expressed that natural history has attained its present high state, and we may, therefore be pardoned for believing that the tree of biological knowledge which has grown to its present height, and which is attaining maturity by attention to such measures is justified by its fruits.

But as the hour which we agreed to devote to our subject has been considerably exceeded, I shall not detain you longer, but, with thanks for your attention, retire from the platform. 




\section{WHAT IS ANTHROPOL,OGY!}

Lecture delivered in the National Museum, Washington, 1). C.. March 18, 1882, ly l'rof. Oris T. Misus.

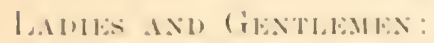

The romer of leretures now proglesing in this hall has for its design the bringing about of a better understanding between sejentific speralists and intelligrent realers and thinkers. With this object clearly hefore no I shall endeavor, as well as my limiterl time will allow, to grive such an cxplanation of Inthropology that my hearers will comfrehend the extent and boumdaries of its teritory and the various operations which constitute its daily life.

"The word anthropology, from anthropos, man : and logos, science, has run through a great variety of meanings, as those who have pursued it have shifted their sroumd or extended their researehes. From 1.501 in 1700 the worel was used to signify. "the stutly of the laws which goreru the union between the body and the mind." In some thenlogreal seminaries it signifies "that manner of expresion by which the inspired writers attribute human parts and par-inn - to the Divine Being." In Dr. Hodere's "Theolenr." all that relates to man is alled Anthropologr. Ju 17\%:. Diderot amel [)" Ilembert defined it as "a treatise upon man." In 17s.S. Kant wrote a work entitled " In Jisoy upon . Inthropulogr:" Latham in his. " Natural Varieties of Mau," (Lond. 1s:30, p. .59,) says, "Antlupolow determines the relations of man to the other mammalia: ethololugy, the relations of the different valieties of mate to each othere."

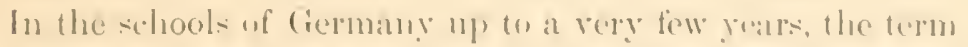
cosereel only what is included in the thirel sub-elivision of

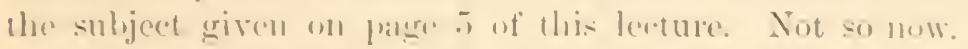
Paul Brocal tells us "Anthroguloug has for its object the sturly of lommanity in its entirety, in it- letails, and in its relation with the rest of nature."

Anthropologs: therefore, while it cxelusles moleh that is

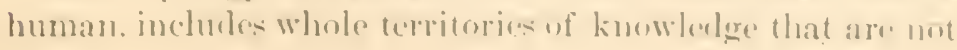


directly human. Biography, as such, is not anthropology, unless it connotes greneric data. History, the biography of political societies, is only anthropological so far as it is not merely biographical.

Physicians were the first and are now the best anthropologists, yet not all in medicine belongs to the science. The same is true of every other profession and craft of men and women under the sun, each has in it a great deal that is not, but more that is anthropological.

Anthropology is the natural history of man in its widest sense. It embraces all that we mean by such terms as humanity, mankind, the human species, human nature. Nay, more. As we cannot study any species as a detached group, so we must include in our science all those natural objects, relations, forces, and facts, that have furnished the material, the impulse, or the limitation to human progress.

What human events and products are anthropological? I answer, those that are human, generic, tribal, capable of scrutiny over large areas, by statistics or by instruments of precision; whatever is customary, whatever can be shown to be a child of the past or a parent of the future. Eliminating those local eddies of thought and action which begin and end with the individual, and which constitute his biography, it takes notice only of those great currents of human phenomena that echo round the world. It therefore both includes and excludes,-includes, and day by day increasingly-all phenomena, material and psychical, related to the development of our race; excludes even human activities that are only the dust upon the mosaic of civilization.

By what methods does the anthropologist prosecute his work? I answer, by the most vigorous and exacting methods. By careful observation of multitudes of facts, by judicious discrimination of those marks which have true scientific value, by careful induction or classification, by* cautious and modest deductions he plods his weary way.

Who may be an anthropologist? Every man, woman, and child that has sense and patience to observe, and that can honestly record the thing observed. There is not 
anothere seience that has not been maicl of honor to this queen of sciences. If the rank of any branch of knowledge is to be judged by the intrinsice value of its objectmatter, and by the number of other seiences ancillary to it, then anthropology must bo alvaneed to the hearl of the line,-having no lese a finction than to explore the secerets of man's origin, progress, and destiny.

Ilaving said thus mueh upon the seope and intension of anthropolugy, it becomes us to examine its sub-divisions, which represent especially the various classes of men enengaged in its pursuit.

\section{THE DIVISIONS OF ANTHROPOLORY.}

I. The origin of man, inquiries into the time and the location of that event, as well as the natural processes involved, and his pristine condition. ANTHiopogexy. (. Inthropos, man, and genea, descent.)

II. 'The early history of the race. Aremaorogr, (Archuios, ancient, and logos, scisucre.)

111. 'The humin species as a member of the animal kingdom. Axthliopo-Bromogr, (Bios, life, the life history of mankin(l.)

1V. The races of men, descriptive= lisuroglislny; deductive=Erhologr, (Ethnos, people, and graphe, to describe, or logos, seience.)

V. Mind in the lower anmals and in man. J'srenology, (Psuché, the soul, and logos, science.)

Y'. The origin, yrowth, and diversity of language. Giosiologir, (Glössa. a tongue, and logos, science.)

V1I The elaboration of human art and industries. 'Trechsologr, (Techne. art, and logns, scienre.)

VIII Social structures and functions. Socromocr. (Socius, un associate, und logos, science.) 
IX. Beliefs and practices with reference to the spirit world. Comparative Mytiology.

$X$. The relations of the physical universe and social environment to human history. Hexiologr, (Hexis, habit, and logos, science.)

By your permission I will now take up briefly these divisions and state, not what my own opinion may be, but the struggles and the difficulty which engage the students of anthropology the world over.

\section{I.-I I thropogeny.}

The great battle which has been fought with reference to the origin and the antiquity of the miverse, is now being repeated with reference to the origin of man. As in astronomical observations each observer has his personal equation, which must ever be kept in view by those who would utilize his material, so into this discussion have men brought their theistic conceptions. We lave, therefore, many theories of man's origination, a few of which I will give you.

I. Special creation by Almighty fiat.

II. Atheistic agnosticism, (a not, and gnossis, knowledge,) denies the Creator, and affirms ignorance of man's origin.

III. 'Theistic agnosticism. Aftirms the Creator, but denies knowledge of the method of human origin.

IV. Pantheisns, (pan all, and theos god). God is all and all is God.

V. Itheistic Darwinism. Denies the Deity and affirms natural selection as the cause of nature.

VI. Theistic Darwinism, (God not immanent.) Affirms the Deity, but denies his constant presence.

VII. Theistic Darwinism, (God immanent.) Aftims the Deity, and also his presence ever in his works. 
V111. Ignostit Harwinism. Aflirms natural selection and ignorane of a C'reaster.

There are five distinet questions regatding the origrin of

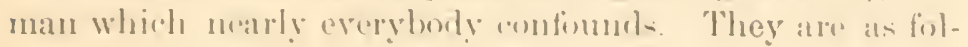
lows:

1. By which of the processes indicated ahose did the human species haw its origin? Wre they areaterl. or disl

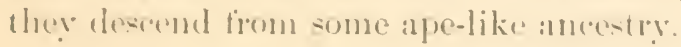

I1. When tid that resent take plater: Mil- it six thousand years age? Was it just on the hither verge of the latest

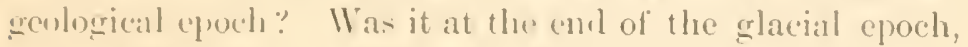
in its midlle, or just before its begimning, or wats it further batek, at the berimning of the l'ertiary that the first lecing wortly to be called a man appeared on carth? It would take far more than my hour to discuss this puestion of the antiquity of man alone. and, furthermore. I am mot invited to discuss, but to deline.

Ill. The thind inquiry is, where did the first man alight upon this planet:

Acrorkling to Moses and Harckel, followed by nearly all morlern anthropologists, our first parents lived somewlere near the Persian Gulf. But there is harlly a spot of the habitable globe that has not been lookerl upen as the farored birtlpplare of man. Is no question in sejence is elosen als yet. if anyone of my hearers is disposed to have his per theory regarding this matter he will not he excommunieated so fir as I am encerned.

IV. Bordering elosely upon the last puery, and allecting it. is the problem of the unity of the speede. Mre atre all nware that our distineruished rountryman, Dr. Merton, followerl by . Inasiz and many othors, held that ons specius had its origin, not in one, lut in several rontions. The weight of anthority at the present time is in fitror of at single origin. Profesor Ilenry wrote, in 1stif, "l'he -pontalncou- generation of either plants or animals, although a 
legitimate subject of human inquiry, is as yet an unverified hypothesis. If, however, we assume that a living being will be spontaneously produced when all the physical conditions necessary to its existence are present, we must allow that in the case of man, with his complex and refined organization, the fortuitous assembly of the multiform conditions required for his appearance would be extremely rare, and from the doctrine of probabilities could scarcely occur more than at one time and at one place on this planet."

$V$. The last question concerning the origin of man is well represented in the controversy of Sir John Lubbock with Archbishop Whately. The former maintained that man was at first a low savage, and that the course of history has on the whole been a progress towards civilization. According to the latter, man has always been pretty much what he is at present.

\section{II.-Archæology.}

Bordering close upon anthropogeny is arehæology, whose province it is to discuss the first efforts of the last child of nature to walk forth into the broad world. The data are far from complete, but are becoming more adequate to show the adrance from rude stone to polished stone, to bronze, and finally to iron, as the material of human implements.

In this study the geologist, the linguist, the anatomist, technologist, and the sociologist meet to reconstruct priscan society. Is the present epoch epitomizes all preceding epochs of the world in its fauna; so does the ensemble of humanity to-day comprehend all past histories. It is no more difficult to reconstruct an ancient tribe from a few human bones and implements than for the comparative anatomist to re-edify an extinct animal from a few of its fossil remains, 1 could give you no more convincing proof of what I say than to invite you to study carefully Professor Rau's archæeological collection, in the Smithsonian Building. 


\section{III.-snthropm- Binlon?!).}

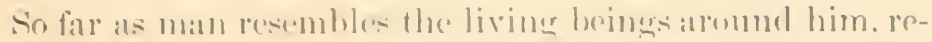

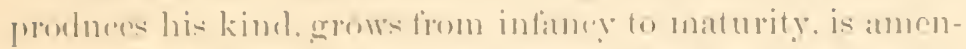

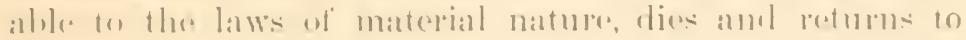
inorgande mattre, hr is an animal. Igain, a mimute anmfalvism of lis holy with that of animals shows a vriking

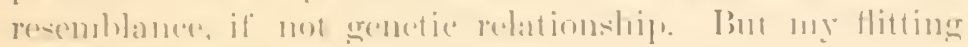

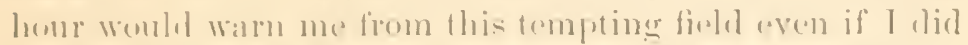

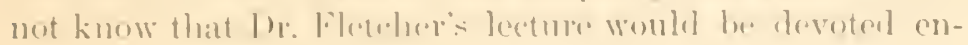

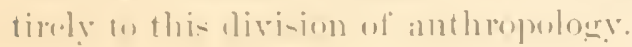

\section{IV - Ethmolog!!}

'Thus tar we have spuken of all mankind. Wrecome nur to inquim what notion anthropmlogy takes of the varioties of ment. It first flumesht rom womld say that it is the easion matter in the worlil to elistinguisle a white matu, a negero, an Indian, a fhimaman. and a hrown Malay. As we

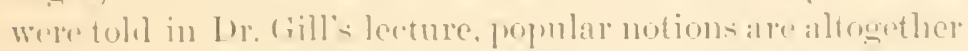
at liunlt. If we amlal stame all the men of the world in at

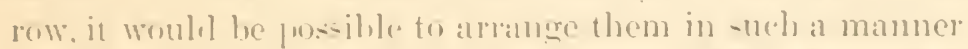

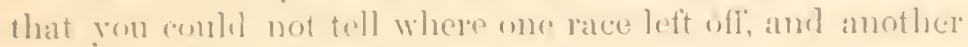
began, and rect stmlento of all have always reengnized race

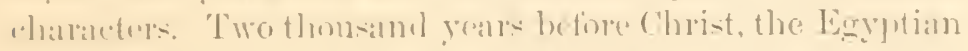

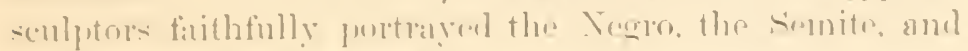

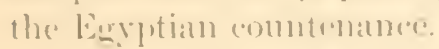

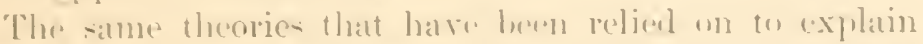
the origin of man. hatre lesen inverent te explatin the diverse

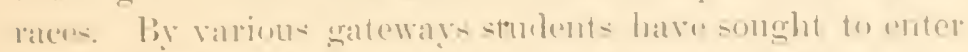
the my-lery-by the color of lhe skin, the sections and

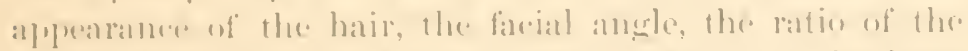

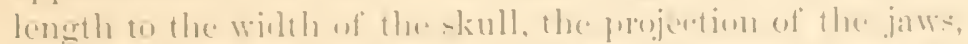
language. rustoms. leelicfs. rete. Sow 1 am sure that all

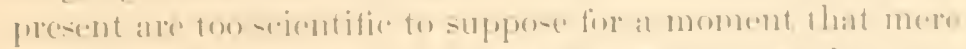

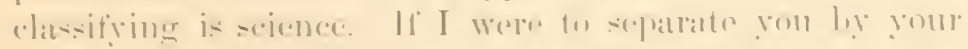

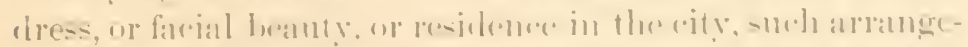

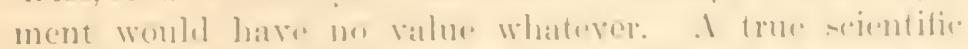
classification is bacerl. tir-t, on immmtalule attributes, and, 
second, seeks to aseertain relations, affinities, and consanguinity. Linnæus (1741-1783) made four divisions of man, Blumenbach (1752-1840) established the five clnsses which are kept up, in our geographies to this day. I should only weary you repeating catalogues of authors and their schemes of mankind. I give you a table by the latest authority" Dr. Topinard, based on the hair, the skull, and the complexion, (Paul Topinard, Revue d'Anthropologie, 1878, p. 509.) It is very far from satisfactory, however, and the classification of mankind is still an open question.

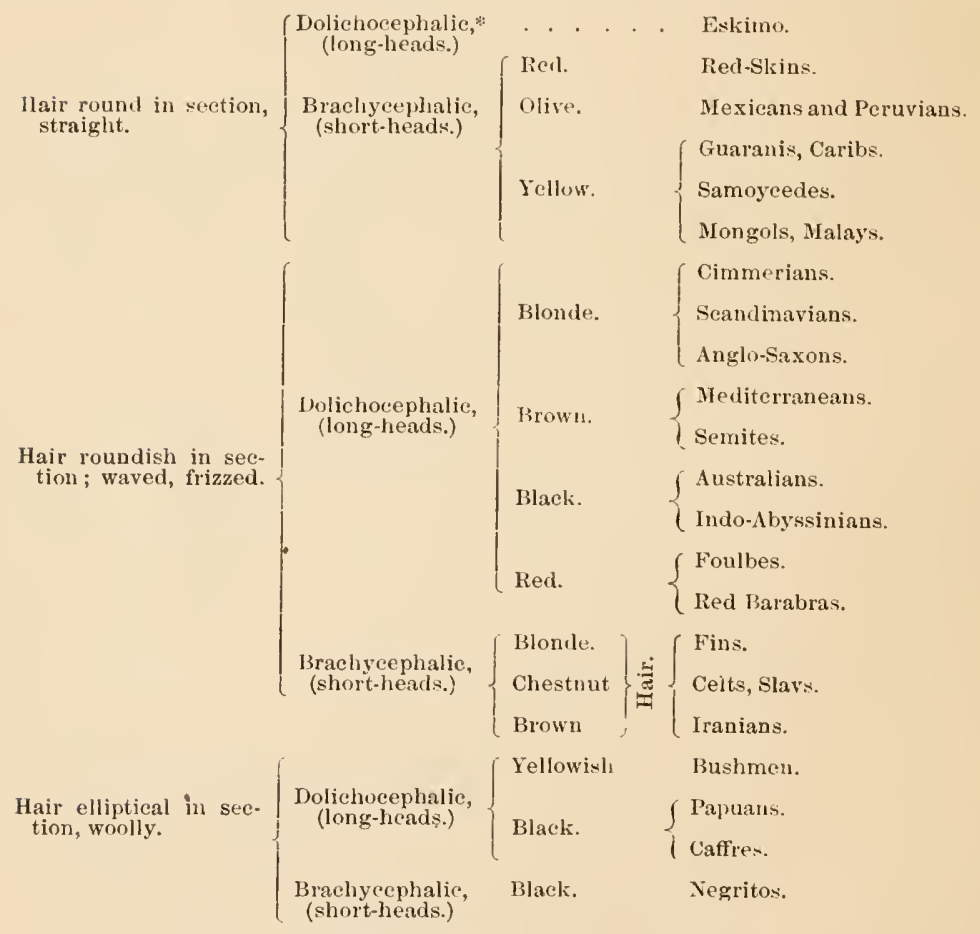

* Dolichocephalic $=$ dolichos, long, and kephate, head; brachycephatic = brachus, short, and kephale, head. 'The angle of the jaw gives rise to orthognathous $=$ orthos, erect, and gnathos, jaw ; and prognathous = pro, forward, and gnathos, jaw. See Topinard's "L'Anthropologie," Paris, I876, pp. 254, 26r, 299. 


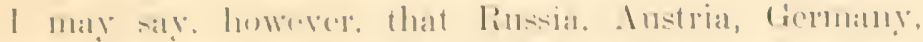
Fanne, lingland, and the Juited Statex have each organized sperial buldats for the minnte (xambination of the je(t)les within their limits.

\section{V.-Ps!ytholu!!!!}

What hal anthropology to lo with metaphysice? Inst

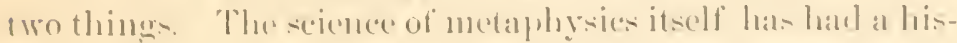

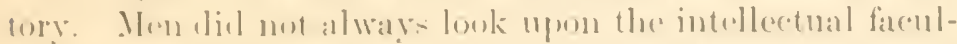

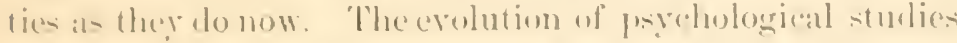
i- eretainly as interesting an the life history of any livine

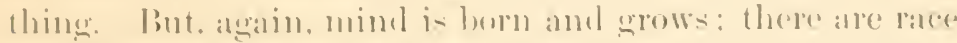

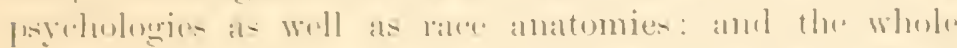

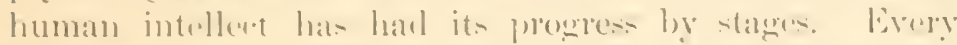

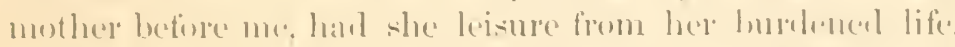
ianlil write a most wonrlerful elapter in antlopologs. by

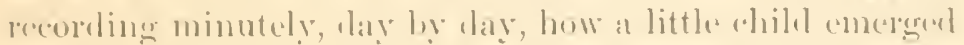
from the ehase of ienorance amel proseresent in the mulolding of it-minel he the anpuisition of knowledere. I -hall

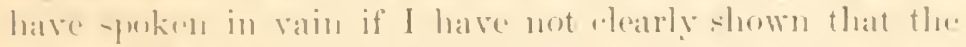
arelage history of the individual is the history of the race. amd that this ereat grime of hmmanity took am idlat just as lase tlue littlo child.

Ienin. honten have minds. Inthropology is making the most exhan-tive investigations inte the question whether they diflier fom us in quality of mind or omly in regrese: whether the instinct-of the brute are the parents of human thoughts. In this portion of the sulject is imvelved the vederl inguiry whether the brain generates thomght as the liver does bile; or whether there is a spirit in man whieh (n)stitutes his troc individuality for which his boly is only a termporatry alobling plase.

\section{II-Vilossolog!!}

'The department of anthropology which investigates languatge is variously tement, linguistics, philology, glosiology, and thr seience of langunge. It has for it-object to inquire 
into the origin of language, and many hard-fought battles attest the energy with which the various champions have entered into the subject. Languages have changed and differentiated. How, and througl what causes? They mix, and new languages arise. They have their anatomy and physiology. They have their purcly physical side, being composed of muscular gestures and vocal utterances, purely physiological. They have their psychological side, "Sound is but the curtain behind which is concealed the mystery of thought." As before stated, the whole history of man is the unfolding of mind, and language thus becomes a historical science. The anthropologist does not stop with vocal speech. For him bodily attitudes, animal voices, the gestures of the dumb, and of lower races are language. We have in this very building a Bureau of Ethnology, where, under the direction of Major Powell, such specialists as Mallery, Dorsey, Gatsehet, Hinman, and Riggs are wrestling with the American Indian languages. The same zeal characterizes the cultivated nations of Europe. The vocal and written speech of man is found to have kept pace with the progress of his thoughts.

The growth of language is spoken of as having passed through three stages, or as oceurring in three fundamental types:-

1. The Holophrastic, (holos, whole, phrasis, phrase,) in which whole phrases or sentences were thrown into a single utterance; or polysynthetic (polus, much, and synthesis, compounding.)

2. Agglutinative, (agglutino, to fasten or glue to,) in which the words are much compounded, but only one of the wordelements retains the ancient forms, the others being pared down to mere appendages.

3. The Inflected, in which relations are indicated by endings, which no longer have any meaning, but serve merely to indicate the function of their stem. The whole subject is thoroughly and freshly worked up in Major Powell's "Introduction to the Study of Indian Languages," which I would advise you all to read. 


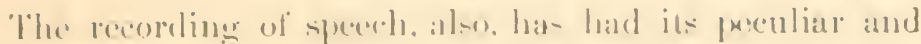
intereting antre of life. Beginning with mere tally stieks,

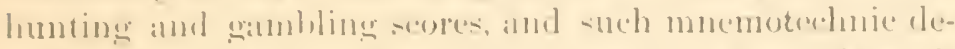

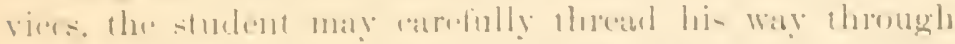

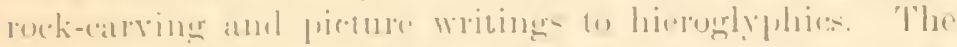

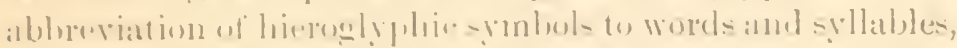

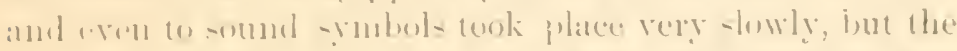

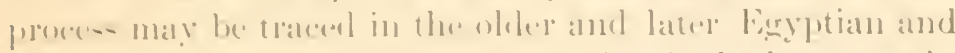
Chaldean writing-. The ant of printing in the last stage in

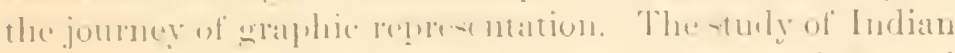

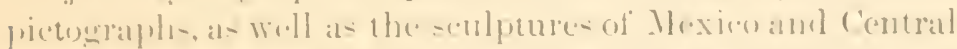

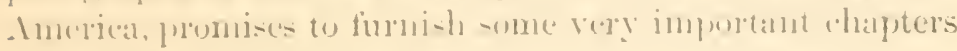
in the listory of lingui-ties.

\section{VII.-Techuedog!}

The portion of my - nhlyeer in which mo-t of my hearers are interested, howerere is the evolution or the elaboration

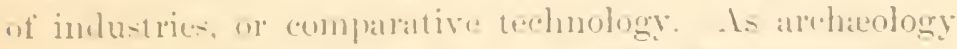
reveals the progress of invention in time. - (technology reveal: the diffu-ion of the gatle of culture overe the calth The twa an twin -istel's of the operative of material side of

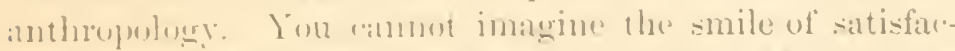

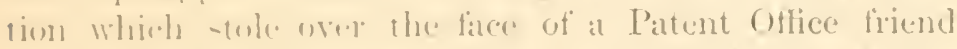
when anvinced that -

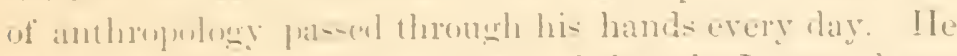
"xrlaimed." I in anthropologist! I thonght I was ouly an rxaminer. I an going to write a paper on anthropolongy." There is not a phase of civilization that has not hatd it:

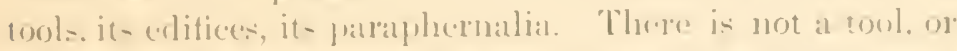

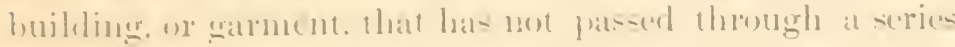
of tran-formation- most interesting to trace. Thee olyects

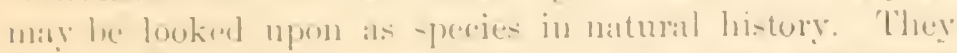

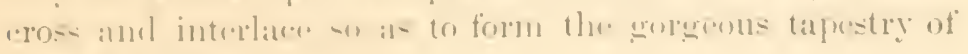

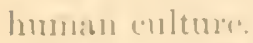

To mis lasly fricul= I would sily thi- mbject is of thrilling interest. There is unt at thing that yon wear, or aat, or enjog, that has met comm down to yon through a wonder-

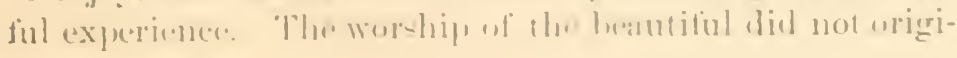


nate with Oxford students in the XIXth century. "Woman was the first potter and embroiderer. She is everywhere the primitive decorative artist, and it is the exception that man occupies himself with ornamental art, even in civilized countries. Woman covers with ornament everything her hand touches, and the lady in her boudoir industriously embroiders on some article of mere luxury, the same series of frets and scroll borders which, on the Amazonas, the savage, unclothed squaw as diligently, and with as firm a hand, traces with a spine on the damp surface of the clay she is fashioning." It is as if they sang the same simple song, like a silver thread binding all lovers of the beautiful into a common sisterhood. Could we find the missing links, the arts of Egypt, Assyria, (ireece, and liome would not stand out like green islands of the sea, but wonld form the necesary parts of one homogeneous structure.

The idea has seized the fruitful mind of Professor Goode, Assistant Director of this grand Musemm, and you will read in Professor Baird's Circular No. 2. as follows:

In the new building will be concentrated all the industrial collections, and all the ethnological specimens, except the reserse series of pre-historic stone implements. In the old building will be kept those collections which are most important as material for purely scientific investigation, such as the main collection of birds, the fishes and reptiles in alcohol, the marine invertebrates, etc. The new building will, however, contain the collections in economic natural history.

The collections in the new building are intencled to form an Anthropological Museum, organized upon the broadest and most liberal interpretation of the term "anthropology," and illustrating the characteristics of civilized as well as savage races of mankind and their attainments in civilization and culture. The central idea will be man, and the manner in which he adapts the products of the earth to his needs. All useful and noxious animals, plants, and minerals will be shown, industries by means of which they are utilized-by both method and finished product-and finally, the various objects which men use for any purpose, whatever. A place is provided for ezery object which has a name."

*At this point several series of objects were exhibited to the audience to illustrate the two ideas, progress and adaptation. Among them was the growth of the ship from the dugout through the skin boat (variety : birch-bark canoe) to the steamer Fish Hawk; the erolution of the knife, the hammer, the bottle, the saddle, food, and ceramics. 


\section{VIII.-Sucialo!!!).}

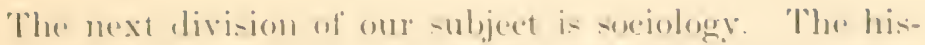

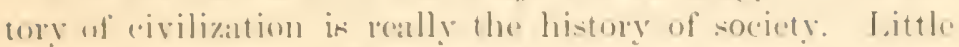

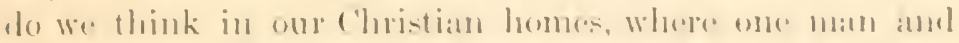

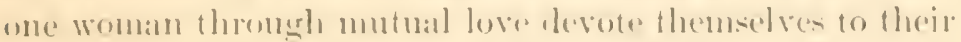

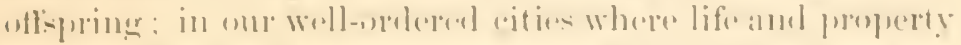

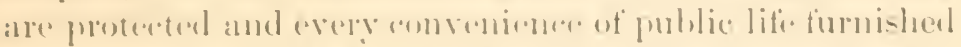
to rich and puor alike: in om grand nationalities and world-

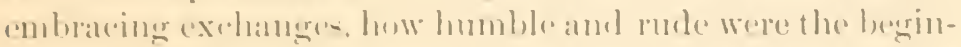

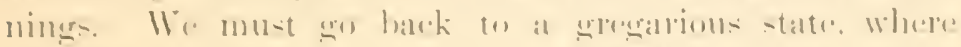
brothers ame sister- intermatrienl, where the bond of moim

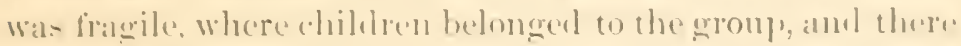

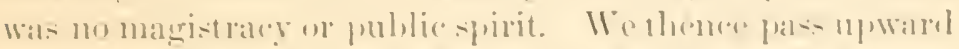

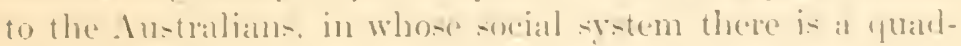
ruple clasifieation of male and fomale for malriage and other purposes. The Sorth Imerican Inlians furnish the

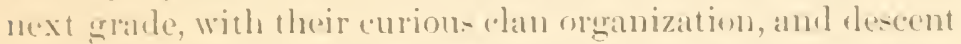
in the timale line. * Passing onwarel through semitic polygamy, wr are bronght to oml own platform of social life in all it-complexity. There a 'o vast territories of knowlerlge, inchuling ecremonial institutions, ethical coules, morality,

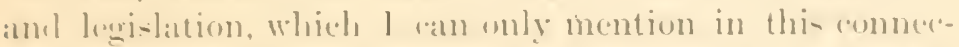

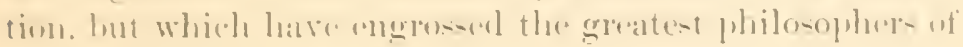
the

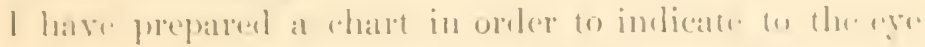
how the poneress and arlaptation- of relture in the valroms

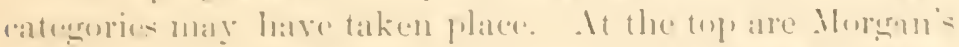

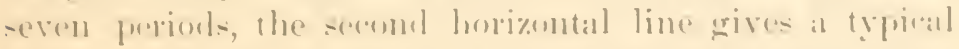

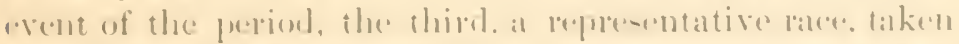

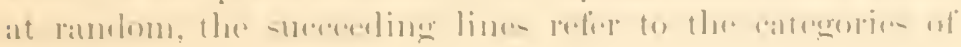
.11 turr.

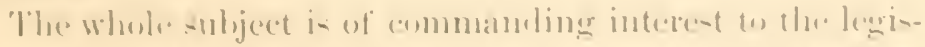

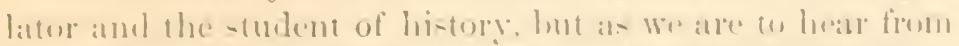

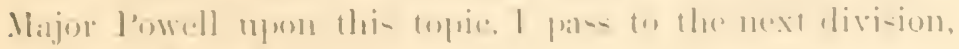
the spinit 11 inll.

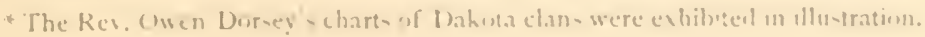




\begin{tabular}{|c|c|c|c|}
\hline CATEGORILS. & \multicolumn{3}{|c|}{ GRADES OF CULTURE. } \\
\hline Moligan's SeHWJE......... & Lower Savage.............. & Middle Savage............. & Upper Savage................ \\
\hline ('HARACTERISt'Les........... & No fire, rude stone...... & Fish diet, fire............... & Invention of the bow...... \\
\hline Riser $\ldots . . . \ldots \ldots \ldots \ldots \ldots \ldots \ldots$ & St. Acheul.. ................. & Australians.................. & Nomadic Indians............ \\
\hline 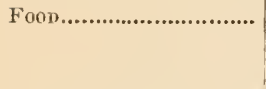 & $\begin{array}{l}\text { Raw products of the } \\
\text { earth. }\end{array}$ & $\begin{array}{l}\text { Indigenous products, } \\
\text { roasted and stone- } \\
\text { boiled food. }\end{array}$ & $\begin{array}{l}\text { Dried meris aud plants, } \\
\text { dug-out vessels for } \\
\text { cooking. }\end{array}$ \\
\hline Clotmino....................... & Nonc, ol a wind shield. & $\begin{array}{l}\text { Capes of skin or coarse } \\
\text { matting. }\end{array}$ & $\begin{array}{l}\text { Caps, body clothes, moc- } \\
\text { casons, of the sexes } \\
\text { mueh alike. }\end{array}$ \\
\hline Halitations.................. & Caves and shelters...... & $\begin{array}{l}\text { Temporary huts and } \\
\text { wind-brealss. }\end{array}$ & $\begin{array}{l}\text { Tents and wigwains iu } \\
\text { clan-groups. }\end{array}$ \\
\hline IMPLEMENTS............. & Palæolithic.................. & $\begin{array}{l}\text { Charred spears, ham- } \\
\text { mers, knives, nets, } \\
\text { dug-onts, fire-drills. }\end{array}$ & $\begin{array}{l}\text { Skin-dressing, bask ct- } \\
\text { weaving, bow-dressing. }\end{array}$ \\
\hline Wri.droxs................... & Clubs and stones.......... & $\begin{array}{l}\text { Spears, elubs, boomer- } \\
\text { angs, throw-stielss, } \\
\text { shields. }\end{array}$ & $\begin{array}{l}\text { Bows and arrows in great } \\
\text { variety, scalping knives. }\end{array}$ \\
\hline Loconiotion ................... & No appliances.............. & Trails and landmarks.. & $\begin{array}{l}\text { Snow-shoes, sledges, ding- } \\
\text { outs, lafts, and skin- } \\
\text { boats. }\end{array}$ \\
\hline Asthetic Produets...... & $\begin{array}{l}\text { Painted borlics, strings } \\
\text { of shells, whistles and } \\
\text { wooden drums. }\end{array}$ & $\begin{array}{l}\text { Feathers and paint,gor- } \\
\text { gets and limb trap- } \\
\text { pings, stick and skin } \\
\text { drums. }\end{array}$ & $\begin{array}{l}\text { Tattoo and paint, embroi- } \\
\text { dery and fringes, rat- } \\
\text { tles and bells. }\end{array}$ \\
\hline DOMESTICATIOX.............. & Fone $\ldots \ldots \ldots \ldots \ldots \ldots . . . . . . . . .$. & The $\log . . . . . . . . . . . . . . . . . . . .$. & $\begin{array}{l}\text { Dogs, ponies, deen. In } \\
\text { the south, bipuls. }\end{array}$ \\
\hline IXDणsTR1Es................. & Hunting and fishing... & $\begin{array}{l}\text { Supplying wants, little } \\
\text { division or barter. }\end{array}$ & $\begin{array}{l}\text { Hunting, fishing, gather- } \\
\text { ing, barter, wampum. }\end{array}$ \\
\hline LAvGUAfE, $\ldots \ldots \ldots \ldots \ldots \ldots$ & $\begin{array}{l}\text { Interjectional and by } \\
\text { signs. }\end{array}$ & $\begin{array}{l}\text { Guttural, clicking, re- } \\
\text { duplicative. }\end{array}$ & $\begin{array}{l}\text { Agglutinative, prone to } \\
\text { dialectic change. }\end{array}$ \\
\hline KXoWL EDGE................. & $\begin{array}{l}\text { The habits of game, a } \\
\text { little about the stars } \\
\text { and the weather. }\end{array}$ & $\begin{array}{l}\text { Count four, predict } \\
\text { weather, judge local- } \\
\text { ity and distance, } \\
\text { name species. }\end{array}$ & $\begin{array}{l}\text { Decimal notation, tine, } \\
\text { genera of objects, natu. } \\
\text { ral phenomena. }\end{array}$ \\
\hline Beriefs....................... & Everything animated.. & $\begin{array}{l}\text { Ghosts, hero ancestors, } \\
\text { animal soul in things. }\end{array}$ & $\begin{array}{l}\text { Sorcery, future life like } \\
\text { this, good and evil pow- } \\
\text { ers, myths. }\end{array}$ \\
\hline WORSHIP................. & Appeasing everything. & $\begin{array}{l}\text { Sorcery, rain-making, } \\
\text { fetisl, worslip. }\end{array}$ & $\begin{array}{l}\text { Medicine pow-wow, inve- } \\
\text { eation by smoke, fast- } \\
\text { ing, mutilation. }\end{array}$ \\
\hline Morals......................... & $\begin{array}{l}\text { Conformity to clan use. } \\
\text { No code. }\end{array}$ & $\begin{array}{l}\text { Conjugal and parental } \\
\text { duties not enforced, } \\
\text { hospitable, inprovi- } \\
\text { dent. }\end{array}$ & $\begin{array}{l}\text { Chastity of wives en- } \\
\text { forced, gencrous, cruel. }\end{array}$ \\
\hline SoctaI, STRUeture..... & Promiscuity ................. & $\begin{array}{l}\text { Punaluan marriage in } \\
\text { gloups. }\end{array}$ & $\begin{array}{l}\text { Ganowanian marriage, } \\
\text { mother-right, clan-sys- } \\
\text { tem. }\end{array}$ \\
\hline Social RITES............... & Not knowni.................. & $\begin{array}{l}\text { Marriage by eapture, } \\
\text { greetings formal, ta- } \\
\text { bu, deposit burial. }\end{array}$ & $\begin{array}{l}\text { Marriage rito weak, Pot- } \\
\text { lach feasts, burial va- } \\
\text { rious. }\end{array}$ \\
\hline
\end{tabular}




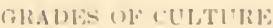

\begin{tabular}{|c|c|}
\hline Lower linrharuns......... & Mid,ll, Burl)areu-. \\
\hline The art of jottiry. & 1)ome-tiontion, crereals. \\
\hline oupunis, Mu4liolii. & Zuñeis, Iztures, ......... \\
\hline 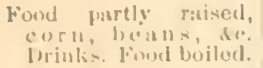 & $\begin{array}{l}\text { 'Tortillus, gruels, cuen } \\
\text { "hile. intoxicunts. }\end{array}$ \\
\hline
\end{tabular}

Shist, uprou, robe, legr-

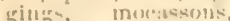
griun, in liesul-dress.

Long-housen num jermanent villagus.

Poli-hed-stone, morlars, woml-working, pottery.

Bow, clut, tom:thawk, senlpinu-knife, of better inulie.

Canoes, litters, earrying pliseor.

Yaint and pendants, toxtile, stome, shell und festhers, flute of iv) nextes, drums, rattles.

Samn ax last. Noothers to disme-ticiste.

Taking from nature, ralsiug crops, nuaking utenila, exchunge.

Moreand sofeng soundw, lioloplirastns longer, woul unil rock carying:-i.

count l(x), w:smpum in historic narration. the stars nse of ined. ieine.

Dreams, wantering glumes firent and Fvil Spirit, minor rleities und livroes.

Religiona orilur sepurat, oftertugs, forsivaly, dinces, niture worship.

labonr degrarlink to inen, disuitu,l, kinul congul and children, ertiel

The same, fatlier-right bugins. แn०l [w-T+und property

Marriage liy presents bull gotneg, ossumriey.
Fisried witl riduk, highly ofmanineterl, then:s

Stone, udobe, liuse, tlat rous, publie builis ings, no moll.

Digging-stick, clay wurking touls, mula trappings.

Ohuiclian nx, spear, ohsillian linilo, dorts, lings, slielel.

Canals, romen, amseways, bridges, llamas, anci, later, muler aust liorses.

l'aint and toggery. (arving in stone und woni, embroidery, drum-, shell-horns, flutus.

Deer, ribblitw, fis], Camel, rww, horse, dog, many hirds, cochimeal. slieep, gont, poultry.

Weaving, felting, dye- Metallures, raravan inf, stamping, for:un- and shij) erale, marjew, stone cuttiug.

Finty sounds, polysynthetisms liljhonic, symbulic ivriting.

Vige-inal winntinz, rulcular, natural lij-tury, meliriue, tuap.

Superstititions, Lh\%e. folilurermua, eleweut (worslip), reven grout gouls.

Priestly eizste, pauther on, lium:us sacritices. waths, ruw:, fuvtw, penanow.

Subminaive. unclisute minl ilrumkarda pun. isheil, trum, kind, fohivilronis

The samn, tather-right, [ori]ures inure isulivilinalizol

Marriagn olsborate. cames, erereusoniouse ness, at $t$ ond $\Omega$ n t lisllo..l at the grove.

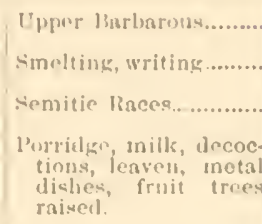

if enton, linem, und woollens stutlis, varied with lank and oeeasinn. wood, leys rommunal, shops, arches, streets.

lerrlug, woaving, inealits, and farmini.

Flint-locks, wall and unoat, sword and lanee

Beast s of burden, tloats, opert ships, camel trails.

fewelry and seents, masivive structures, inusic varied, juetry ornati. lects, thirs.

II ifhly intlectional. writing syllatic or a! phabetie, literuture.

Astronomy, geograpliy, mealieine, history, Iaw:

Innotheistic or molythuistic anthroyin morplism.

Sacreil honks, preach. ine praver, listing. a in $=$, clines

"umprorate, lewi, jor lite. lewspitab?a. -lire wal, brave, troat vlerells.

Pstrır, lanl fumily, jн. lycanay, property un sites rilty, der-potives

IInremat ghnas, lonth-

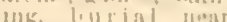
Hlitim. (11)-(lried briclis, stone, rude liundieraft.
Civilizer.

Printing.

Jabler Iryou

Evers variets, an/mal and vegetahli:

Differentisterl lor Mux, rank, und nieguion.

Strictly family, exeord iagly varied, kas, water pipes.

Stimulution of invention by protection and patent laws.

Fire arms perf.celed, iron clads, siennal service, k.

Steam earriage nddro.

Architecture, sculpture. music, painting hol eleitres:

Every Iranch of the anjinal kingdom.

Work in land, forest. mines, waters, commeree.

Inflected, writing, Jrinting, telograph.

Seirne. metaphysirs. li weory, tachnoing: politic..

ford, angels, spirits, fit. ture life, retribution, agıu-tivist, atlatiom.

l'ublic atul privatu. "Tle apirit abue tho forn.

1) lox" Gol supromely ajul uns ripighbor riv untrolvin.

Ionris.anis, family, fotl i.r riklu, Frovetsu

Y.ariage lay priest, war $\mid 1 \mathrm{ral}$ \& if e.remusy. hurial ou graves and tinte 


\section{IX.-Comparative Mytholog!y.}

It is very difficult to find a word to cover exactly the ground which the anthropologist inclurles in the word religion. Among Christian people, the term is applier to certain beliefs, forms, and conduct; and the adjective, religious, would not be understoor if applied to discussions merely; but let it pass.

There never was a people so rude as not to observe nature and to assign causes for everything that passed through the avenues of their senses. Into those causes life is projecter and human or animal attributes added until a philosophy or theology is built up.

Secondly, in some form or other men early begin to believe in a future life, to people an unseen world with innumerable beings, good or bad, and to separate these beings into classes with functions. This forms a creed.

Further, certain actions on our part are due to these beings -will please, displease, or appease them. Men fast, chant, pray, dance, and sacrifice; they deny, weary, and mutilate themselves, for this pirpose. They set apart a class to wait upon the gorls, build costly edifices in their honor, in which the continual sacrifice and savory incense ever attest the fear. or the devotion of the worshippers. Among any people this constitutes their cult.

By the testimony of missionaries and other's, who, like Mr. Cushing, have lived among a lowly people long enough to win their confidence, we are in possession of the facts which will enable us roughly to outline the world's theologies, creeds, and cults. The anthropologist, far from being shocked by the seeming absurdities of these lower torms of religion, beholds in them the germs of all our beliefs. I have frequently thought, while reading of the bloody and cruel fetish worship of the dark-skinned African, that a kind providence had effected the whitening of the human skin coordinately with the purifying of religious conceptions. At 
any rate there has heren progreas in romeliness mol improverment in roligion.

At first, catch individual thing was thought to be ensouled. A little after there were mhostererls, which might be influencerl by fot ishes or incantations. Worship of things, places, animals, and plants follow in quick surecsion. Another step lurings us to the deification of the powers of nature,

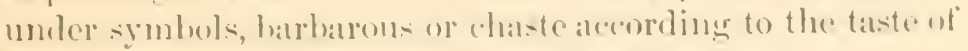
a people. which eomstitute the worlal's inlolatries.

IIow plasantly we might shemel homs tracing through its maty windings the conception of perstulal causation, from the eress forms of savene philusophy to that erramel ielea which traces all creative power and providential eontrol to maje-tic law, "that has it.seat in the hosom of Crod. and its rofece is the harmony of the miverse." With Major Powell, Mr. ('ushing, Mr. Dorsey, and Mr. IInman, we shoule sit lown at the Indians heathstoue and heale in their simple mythe echoes of the rhildhood of the world. With Profes:or Anderson We should visit the prisean home

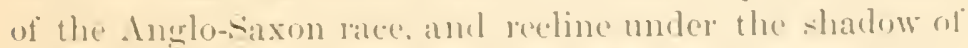

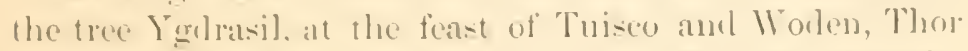
and Fria. Omr smerey could mot omit Chaldara, Asyria, Persia, India, China, or Eegle. IJuch more, the rods, the

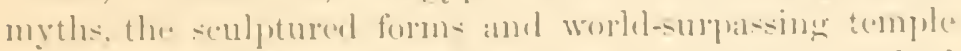
arehitecture of Cireeres, and the pure nomotheism, exilterl

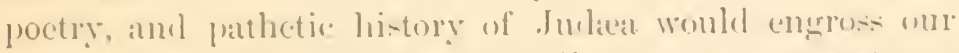
serious thomerhts. Rising above all, get not contemptums of any at last would shine refulgent that moldefilerl ('hris-

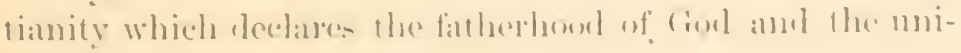
versil brotherlooml if man.

\section{X.-Urivlu!y!!}

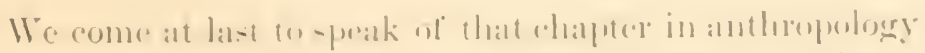

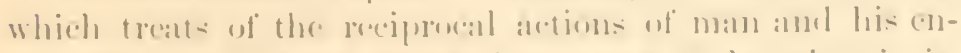

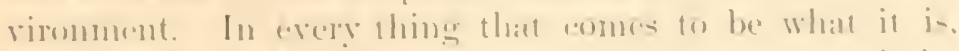
there arre two seis of forece at irork, the internal and the external, the anstruntive amel the setructive, the impell- 
ing and the restraining. We see it in the sea and the shore, the breath of the glass-blower and the mould in which the bottle is formed, the vitality and the favorable or unfavorable location of the plant, the habitat and the vigor of animal species, and finally in the races of men and their inorganic and organic surroundings. The anthropologist has no more difficult problem before him than to ascertain the influence of elimate, outlook, food, and social environment, to produce varieties in man, to set in motion that great eurrent called "the migration of nations," and to bring about from nothing, all that constitutes the various civilizations of the world. Inasmuch as the poorest farmers buy the least productive lands, the sterile districts of a county even will be less cultured than the most fertile; and living upon such ground soon reacts upon the people, only to increase their poverty and to decrease their vitality. How much more, then, may we expect to find the abject races of man living in the suburbs of the world, where squalor is engendered by the surroundings, until there is a harmony or equilibrium between the umpropitious skies and their wretehedness. On the other hand, the contact, the rivalries, and even the bloody wars of favored races have awakened an emulation productive only of good.

It is the business of the anthropologist to trace out these subtle causes and influences which advance or retard civilization, which have covered the earth here with prosperity, there with melancholy ruins. So far from being beneath the consideration of the highest and most gifted intellects, this and not petty expedients should be the subject of serious inquiry by the statesman, the political economist, and the philanthropist.

My task is nearly finished. My object has been to define a science in which there is no priesthood and laity, no sacred language; but one in which you are all both the investigator and the investigated,- - the judge, the jury, and the prisoner at the bar. I have endeavored to portray in outline the work of the anthropologist, so that you may intelligently follow my successors who will treat of special themes. 
I shall not have spoken wholly in vain if I have indicated the lines of all social progress and led you to see, however faintly. the value and indissoluble mion of the humblest human phomomena-

". That nothing walks with aimless feet;

That not one life will be destroyed.

Dr cast its rubbish to the void,

When Gorl hath male the pile complete.

That (iod which ever lives and loves.

One God, one law, one element,

And one far-off, divine event,

To which the whole creation moves." 


\section{CONTRASTS OF THE APPALACHIAN MOUNTAINS.}

Lecture delivered in the National Museum, Washington, D. C., March 25. r882, hy Prof. I. WV. Chickerinc, Ir.

Science pertains to that which is known, not that which is conjectured or guessed at. It is based on facts, and not on theories. A hypothesis may oftentimes be useful in scientific investigation-just as is the scaffolding in the erection of a building, it may even, at length, come to be built in, may become part of the temple of science, but then it has ceased to be a mere hypothesis, and has become itself a fact.

The science of to day, entitled to the name, rests upon a solid foundation of fact, is an induction, not a deduction.

Science, therefore, and especially advancing science, is omnivorous as regards facts. It is a veritable Gradgrind. "Nihil facti alienum est a scientia."

One fact alone does not prove much. It may, if new, interest or surprise, but its chief value will be in its power to stimulate to the collection of other new and kindred facts.

"One swallow does not make a summer," but when the flock has arrived, and the nests are in procass of building, we know the summer has come.

We need, therefore, first of all, a multitude of facts, and then we need to have them collated, compared, classified according to their resemblances and their contrasts. The observation of facts is, for a time, the first duty, the chiet employment of the scientist. It precerles all else, all theories, all classification, all order.

To observe, and as far as may be to collect facts, are expeditions sent out, and thousands of observers at work. This Museum is, and is to be filled with concrete facts.

Now, fortunately many men are born lact-collectors, factmongers, with taste and aptitude for the pursuit of facts. 


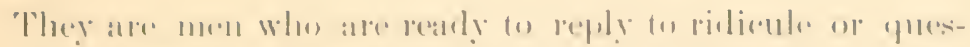

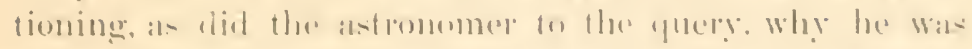
(xpromling an moreh time, money and tronble, in endeavor-

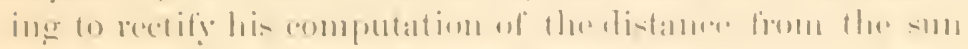

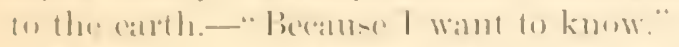

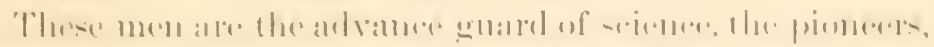

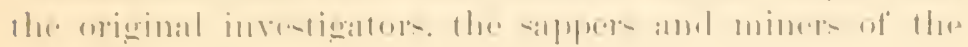

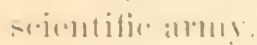

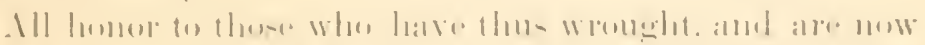

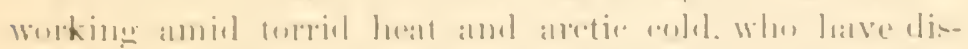

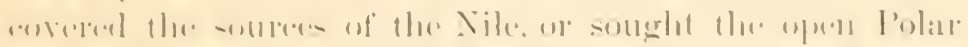

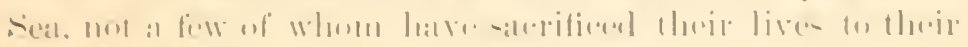
lalline

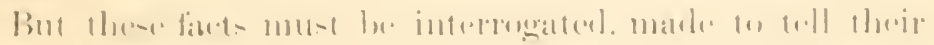

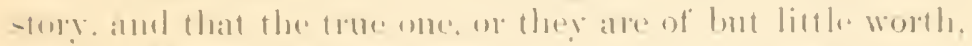

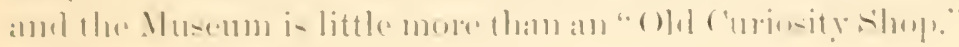

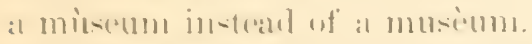

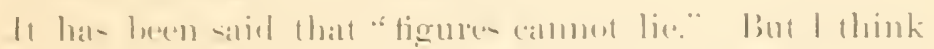
few would admit the truth of that alyog. on the cre of at

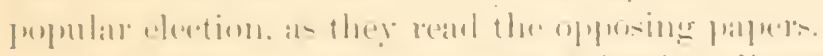

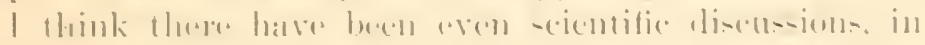

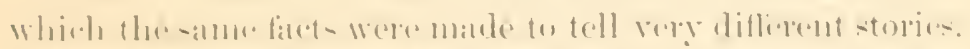

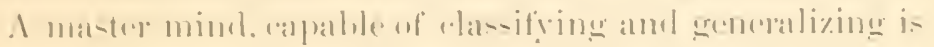

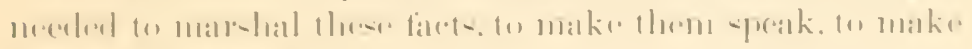
then tall the truth.

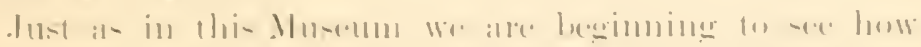

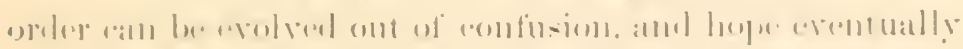

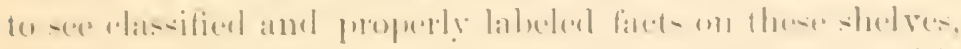

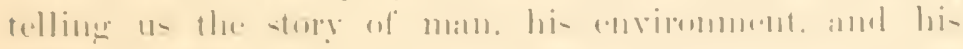
: hiscrememt-

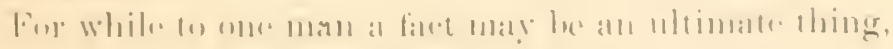

\footnotetext{
. I primase on the riser - brim

1 -imple primme is m lomm."
}

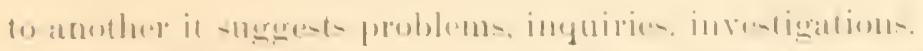

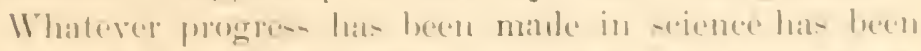

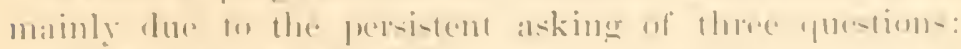

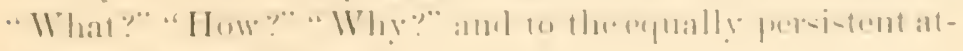
tompt to answer thems. 
The man who takes no interest in these questions will never make a scientist.

When, then, we have been able, in a measure, to answer the question "What?" and have the facts before us in records or in museums, there presents itself to the scientific mind the second query, "How?" How came this to pass? What have been the processes? Can they be repeated or varied?

Here comes in, the so-called practical, economic application of scientific knowledge, the use of facts, nowhere more earnestly studied than in our own land.

The Museum calls into existence the Institute of Technology.

But while some are content to stop here, to others comes irresistibly the query, "Why?" What are the underlying principles? And the query divides itself into two-causal and teleological. What is the reason, the cause, the statement in terms of law? What is the object, the final result, the end to, or for which?

And here in this Smithsonian Institution are gathered men who are giving their lives to the answering of these questions.

The museum, with its facts, both in biology and anthropology, has rendered possible the two lectures to which we have already listened with so much of interest and profit.

Now, in this scientific army, it were well if we all were enrolled, according to our talents and our opportunities, and it is, I suppose, one object of this course to interest, if possible, all who attend, in scientific subjects; to instruct in scientific methods; to give information as to what has been done, and to suggest what remains to do.

I shall now attempt, in accordance with the principles thus enunciated, to state a few facts, possibly some of them new to some of you, to make a few generalizations, to suggest some things to be observed, and some results of observation among the Appalachians.

Out upon the watery waste of the Archean Ocean, as the Eozoic age was drawing to its close, looked here and there a 
few scattered peaks, "ruri nantes in gr rgite vasto," outlining what we now call the Appalachian Mountain System.

It was at the lime when, an we laturn from the earlicst written genlugieal mord, "God said: " Let th = waters under"

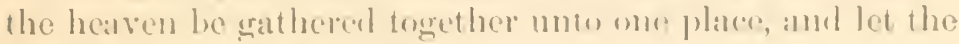
dry limel alpear:' and it was so."

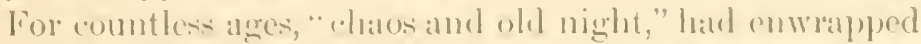
the globe. Itsmolten billows latel surged and tossed in mad turmoil, while enveloping clemst of murk valpors his the fiery mass from sight.

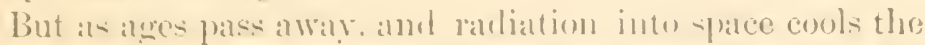
glowing sphere, the valpors breome lesi dense, the light divides from the dirlines, and a erust forms over the liguid grobe, soom to be rent ly internal convulsion, upheaved or submergerl by the gigantir fores at work. partially molted and again olielifierl. till at length a contimental hasis is asstirnt.

Now; with still diminishing heat, the alqueons valpor begrins to condense, forming oceans, and this first great and final diflerentiation into land and sea is aecomplished.

The V-shaped Laurentian IIighlands appear, constituting the back bone of the continent, and detemining the direction of it: future extension, while parallel with the eastern arm, emerge the peaks now seen in the Adirondaleks of New York, the IIighlands of New Jersey, portions of the Blue Ridge of Pemnsylvania, Virginia, and the region- farther sonthwest, including the Blark Hills of North (anolina.

Aroum the bates of these peaks wat doubtless, even then, 'it erreat mass of encissoirl and quartzose rocke, malking great shouls and forming a long line of barrier reefs, proterting the quiet interior ba-in from the fury of the pelanic wave:

Is suceceding age rolled away, in the slowly sinking trough on the west. Wre depesterl turing siluriall, Dero-

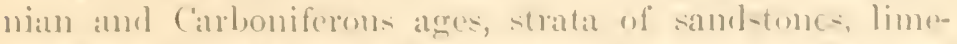
stonce, conglomerates, shales, beds of irom and coal, agrere-

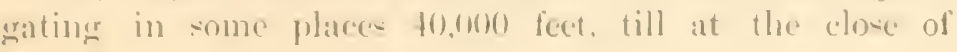


Paleozic time cance a mighty convulsion. the overburdened crust giving way under the enormous pressure from above, and the lateral pressure of a cooling globe, and flexing, fracturing, tilting, uplifting these strata, sometimes to the height of more than 10,000 feet.

Then and thus was the great mass of the Appalachian sistem permanently raised above the ocean, and unimportant have been the changes since, except by erosion, as on the east the waves thundering against its rocky base have pulverized and spread out the sand which lines our coast from Cape Cod to Florida; and on the west the rains and the rivers have prepared and distributed the fertile soil of the Mississippi Valley, and then woven over it a net-work of water courses.

This mountain mass, this great continental fold, extends from the promontory of Gaspé on the Gulf of St. Lawrence, to northern Georgia and Alabanu, for about 1,300 miles, in an undulating line, with a general trend from northeast to southwest, and presents very different aspects in different parts of its course.

On the east, a gently sloping plain extends from the mountains to the ocean, about 50 miles wide in New England, almost disappearing near the Hudson, and then in the Pine Barrens of New Jersey, and the Eastern shore, gradually widening, till in North Carolina, South Carolina, and Georgia, it attains a width of 200 miles. while seaward, it extends from 20 to 100 miles farther, forming those extensive shoals which line the coast from Newfoundland to Floricla.

Its eleration above the sea, at the foot of the mountains, is, in New England, from 300 to 500 feet. In the valley of the Hudson, it rises but little above the sea level, but as we go farther south, into Tinginia, the Carolinas and Georgia, it attuins an altitude of over 1,000 feet, forming a plateau of considerable extent, known as the Piedmont Region, and presenting like the similar plateaus between the parallel monntain chains, a most attractive combination of beautiful scenery, fertile soil, and a climate, for comfort and healthfulness, unsurpassed on the globe. 


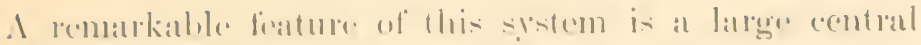

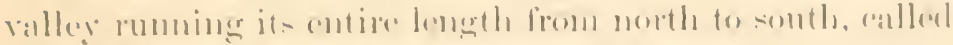

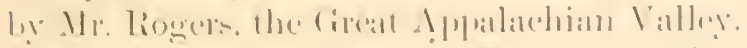

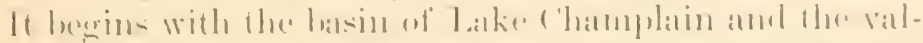

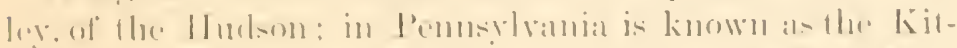

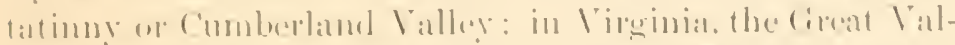

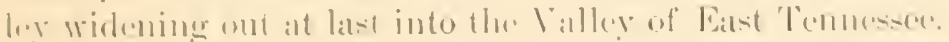

But while llere is this contimule. there is also muels of (4) 1 (1)1-1.

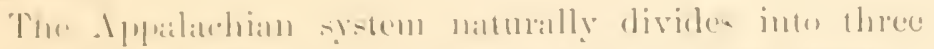

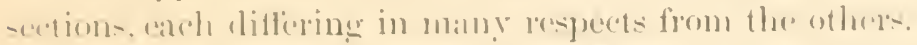

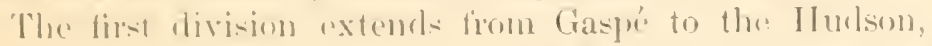
mainly a single landere. known in its diflerent portions: as the

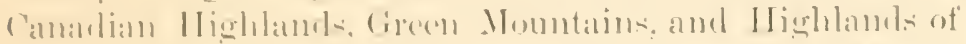

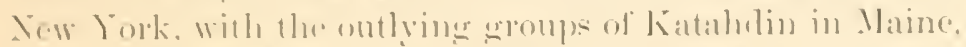

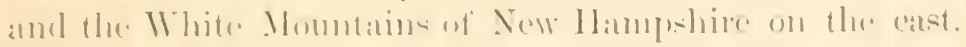

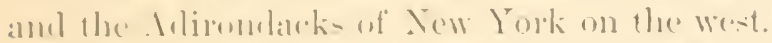

Thi- dain is broken though he the lJuklson and Mohawk,

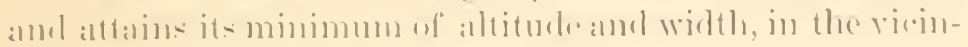
ill of these rivons.

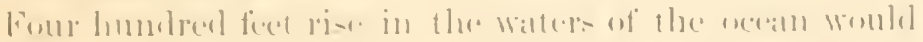

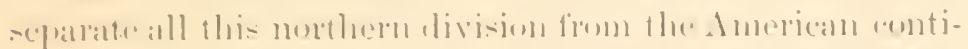

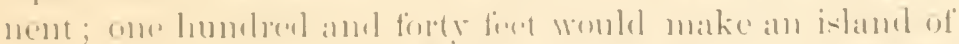

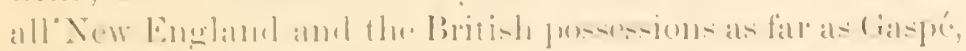

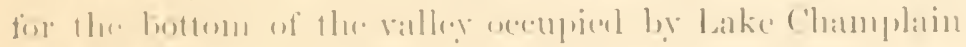

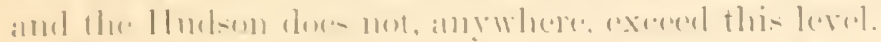

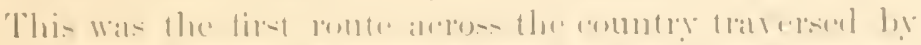

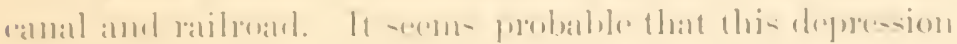

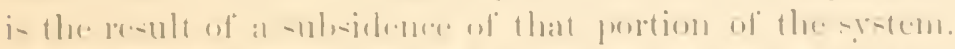

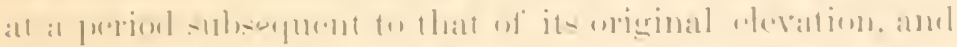

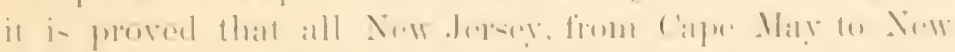

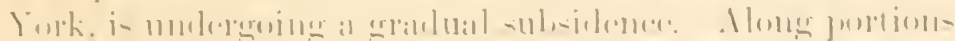

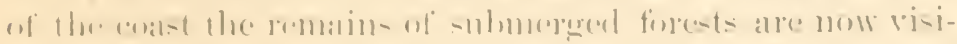

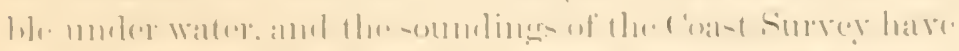

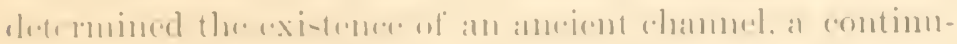

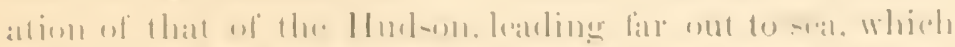

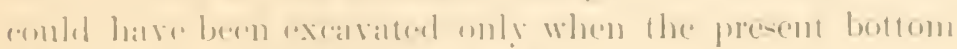

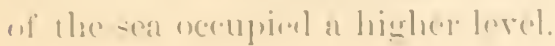


The central portion extends for about 450 miles, from the Hudson to the New River in Virginia. known farther along in its course as the Great Kanawha, is commonly spoken of as the Alleghanies, and consists of many long, parallel chains, separated by fertile valleys, and interrupted here and there by notches and gaps, through which the rivers find their way to the sea.

It is in threading these mountain defiles, and now and then crossing a ridge by zigzag approaches, that the Baltimore and Ohio, and Pennsylvania railroads afford the passenger, views of such surpassing beauty and grandeur.

The system attains its greatest width in Pennsylvania, gradually narrowing farther south, but attaining greater elevation, rising from $S 00$ to 1,500, 2,000, 2,500 feet, and in the Peaks of Otter, in Virginia, reaching an altitude of 4,000 feet.

In Virginia the eastern chain is called the Blue Rirlge, the extreme western range the Cumberland, while the higher range or ranges between is known as the Alleghanies. Thus far the system, though no longer single, is composed of similar parallel wave-like ridges, separated by longitudinal valleys.

From the New River south, this is changed, and the system becomes greatly complicated.

The main chain, hitherto known as the Blue Ridge, is deflected to the southwest, and in a circuitons line for $250 \mathrm{or}$ 300 miles, under the names of Iron, Stone, Bald, Great Smoky, and Unaka mountains, forms the boundary line between North Carolina and Tennessee, rising frequently to heights exceeding 6,000 feet.

While the more easterly range, thence bearing the name of Blue Ridge, and finding its southern terminus at Cresar's Head, in South Carolina, where the ridge turns abruptly to the nortluwest, reaches even loftier attitudes, Mitchell's High Peak rising to 6,717 feet.

In Torth Carolina, these two ranges are more than 50 miles apart, and for more than 100 miles they constitute a great central plateau like that of Colorado, on a small scale. 
Insteal, hemerere, of a continuous lomertulimal valley lw-

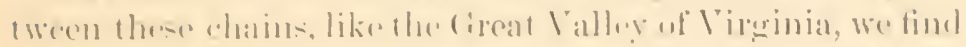

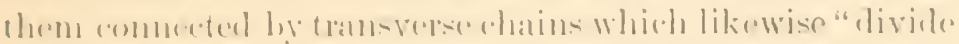

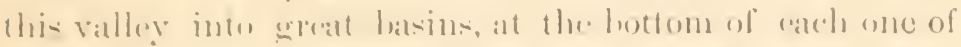

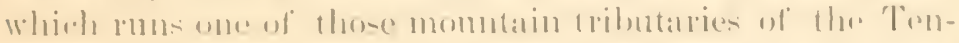

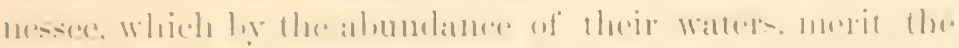

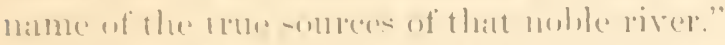

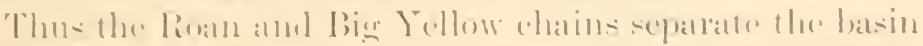

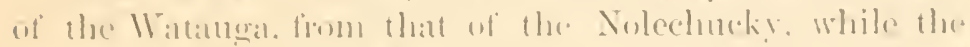

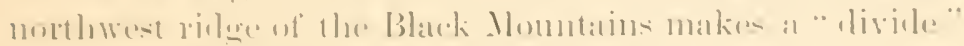

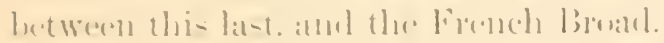

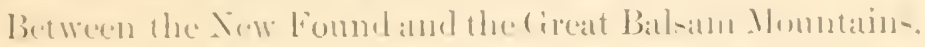
rises the big l'igen liver, while finm the basin between

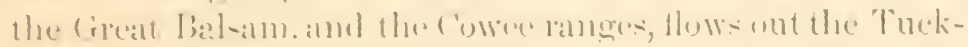

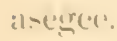

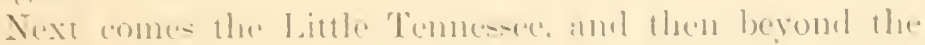

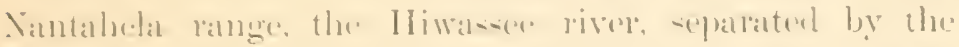

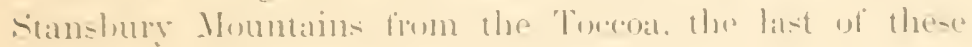
menntain trihutaries of the Temuencee.

Aul, als all these with matny other Jisere. rise in the northwetern slope of the Blue Ridere, draining that latege

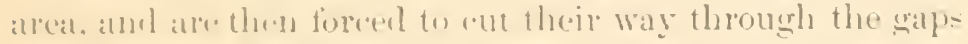

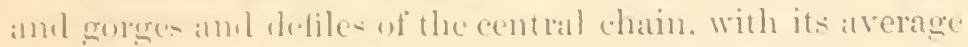

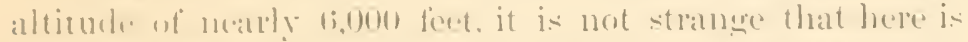

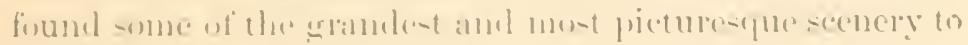
le foumel in the tinion.

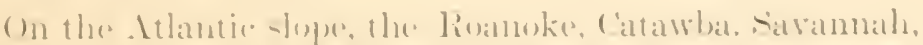

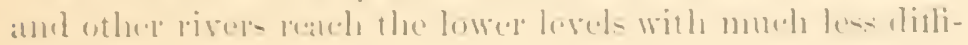
(1) 15 .

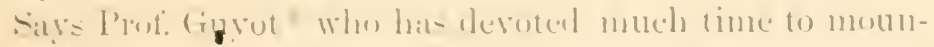

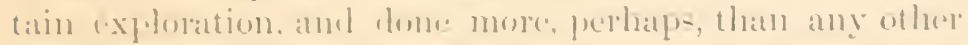
man to nake us actpatinted with onl own momntains, and (1) whom I womlel herr. ackmowledge ny indebtedness for many of the fact- and not a few of the generalizations and

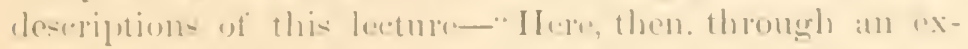

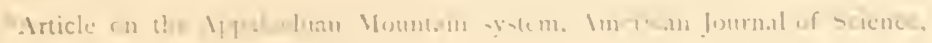
Marct. I 1 . 
tent of more than 1.50 miles, the mean height of the valley from which the mountains rise is more than 2,000 feet; the mountains which reach 6,000 feet are counted by scores, and the loftiest peaks rise above 6.700 feet, while at the north, in the group of the White Mountains, the base is scarcely 1,000 feet, the gaps 2.000 feet, and Mount Washington, the only one which rises above 6,000 feet, is still 400 feet below the height of the Black Dome of the Black Mountains.

"Here then is, in all respects, the culminating region of the rast Appalachian system."

We will now consider somewhat more in detail, the contrasts already in part suggested, beiween the northern and the southern divisions, and will take as a representative of the one, Mount Washington. in New Hampshire, with an altitude of $(i, 28 S$ feet, and for the other, Roan Mountain, North Carolini, reaching 6,391 feet.

First, we will contrast the modes of approach. From Portland, Maine, a railroar trip of about 100 miles carries us through a rolling country, becoming hilly as we approach the mountains, and exhibits a flora characteristic of the latitude, and changing but little till one is half way up the mountain; a railway takes us to the very summit.

From Norfolk. Ta., for 100 miles of railroad through the tide-water region to Petersurg, we pass over a sandy plain nowhere 100 feet above the sea level, and at Petersburg only 11 feet. Thence another 100 miles brings us to Lynchburg, through a rolling country, rising as high as 800 feet-and from there on we plunge among and climb up mountains and platealus, the railroad reaching an elevation of 1,500 feet within the first 60 miles, and for the next 150 miles nowhere descending lower than that, but attaining in places an altitude of over 2,500 feet, till at Johnson City, Tenn., steam power deserts us. A rough stage ride of 25 miles, "rossing the state line into North Carolina. exhibits a striking contrast in the flora.

Following Buffalo Creek for 10 miles in a southwesterly direction, parallel with Buffalo mountain. we trarel through 


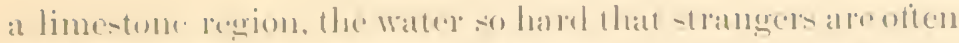

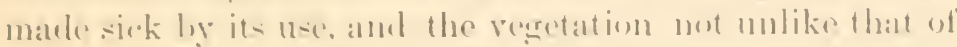

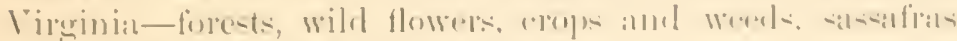

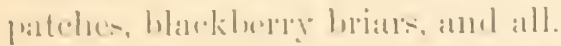

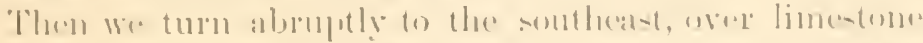
ridges, alelos- a slight water--hed, half a mile in wilth amb

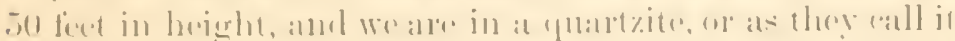

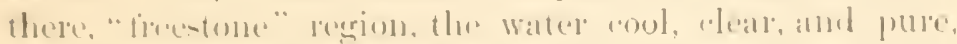

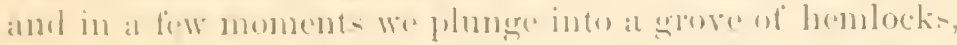

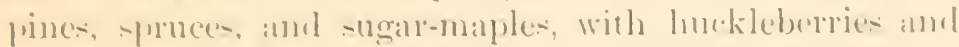
winteroreen beneath, that reminds of of Xew England, while

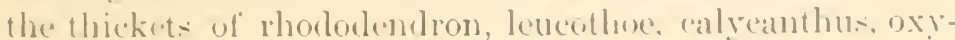
dembrom, and magnolia prove to $u=$ that wo an still in I)ixic.

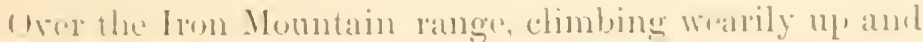
then lattling furious y lown its 1,500 feet of elevation, and we enene to the base of Roan Mountain, standing wut in the smohine more than :3,000 feet abovo us. For seven miles we wind in and out among cliffs and around the heals on lavines, over a roan skillfully engineered, hut fill form reas- mring to weak nelves, and at lengrth we stand on thes sumnit. mpon the houndary line between Sorth Carolina and Tenmpsece, looking ofl upon those two States, amel, in arldi-

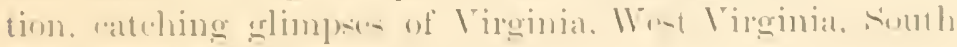
('arolinar. Foreria, and Kentueky.

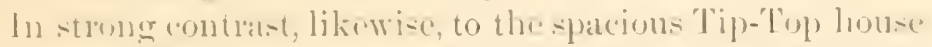
of Jomnt Washingtom, securely anchomed hy lumge chaims w

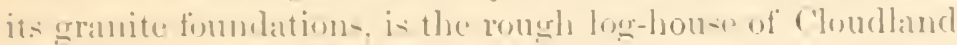

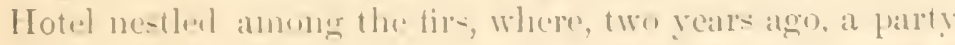

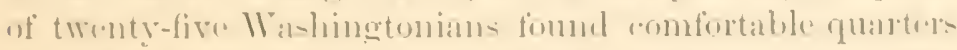

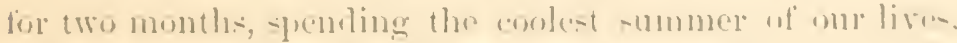
and to sone of $11-$, at lrat. the mo-t emjoyalsh.

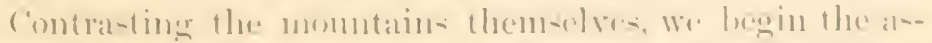

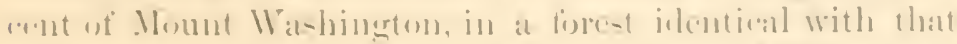

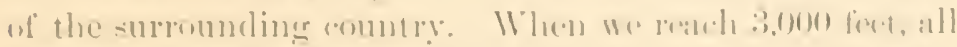

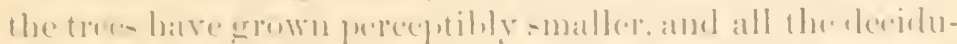
w

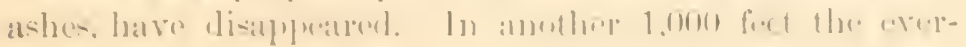


greens have hecome dwarfed to shrubs, three or four feet high. so rlense that you may often walk for rorl- upon their tops. At 5,000 feet, only a few ereeping shrub- remain, and for the remaining 1,200 feet we have only a ridge of barren rocks, with here and there a few grasses and sedges, and a few heaths and mosses with the arctic sandwort. Arenoria Gronlandica, keeping up the struggle for exl-tence.

Ascending Roan mountain, at between 3,000 and 4,000 feet of altitude. we pass through a belt of giant trees. One chestnut measured 24 feet in circumference at five feet from the ground; one black cherry (Prumus sciotina) measured 1? feet, and as straight as a pine, rose 70 feet without a limb, while hundreds of chestnints, sugar maples, lindens and tulip trees were seen from four to seven feet in diameter, and $70 \mathrm{or} s 0$ feet to the first limb.

During the next 2,000 feet the deciduous trees gradually disappear, till hemlocks, firs, and spruces alone remain.

It length, emerging from the belt of evergreen- surrounding, and in places coming to the very summit, we come out upon a grassy slope of 1,000 aeres, the soil rich, black, and a foot or two deep, largely composed of regetable humus, the grass of at most vivid green, and dotted here and there with clumps of mountain alder, (Almus viridis.) and mountain laurel, (Rhododendror Cataubiense, ) the latter one of the most beautiful shrubs that can be imaginer, forming symmetrical domes of dark pink, from 6 to $S$ feet high. Add to this large areas of mountain honeysuckle, (Rhododendion calendulaceum,) with great masses of bloom, rarying from golden rellow to deep crimson, so that the hillside seems a flame of fire, and you ean cease to wonder that Dr. Gray, who first explored this mountain in 1841. pronounces it the most beautiful of American mountains.

These grassy summits or "balds," are a markerl feature of these southern Appalachians, giving a name to one long range, and raise an interesting question as to what climatic or other changes, have sufficed, first, to stimulate a forest growth of deciduous trees sufficient to account for such an 


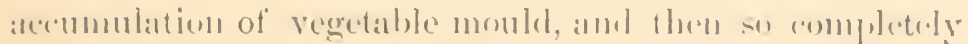

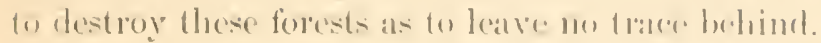

It either end, this gratsy slope is terminaterl hy a rorky

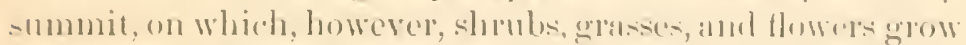
in profusion. hut rising some 70 or so feet aluse llu platin lwlow; these stmomits being about two miles apart, and the

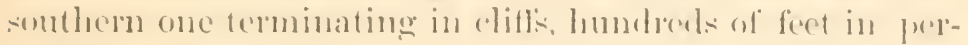
jenclicular height.

As regarels the flora on Mromet Mashington, for the first 5.000 feet we timl but few species which alo not uberverl andund lle base, hut above that oceme some 60 alpine or sub-alpine speries not met with at lower levels till wa alp-

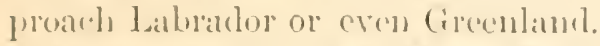

As we aseend from $3,00(0$ to 5,000 fow on Rian mountain we find the flora recalling that of the thick woorls of Maine and Xew Ilampslipe. 'Twenty charateristic species of tho northern woods are abumkant, while closely associated with them are sume 30 species distinctively southern.

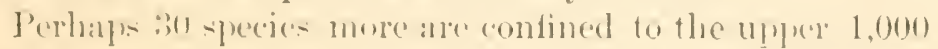
feet.

Some of these aresul-alpine, and replatee those of Momnt Washingron with diflerent species of the same or kindred genera, as Arcuaria glubre in place of a. Girumlandice ; Prenanthes lisancnsis, in place of $I^{\prime}$. nemess and Brottii; Yaccinium crythocorpon, a stragghing shrub three or four feet

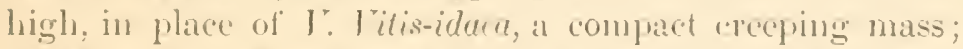
Piledodendron cinturebiense, with its marnificent doness of blonm, in plate of the little R. Lapponicum, only thece or four inches in height; Carer arsticalis and juncra, in plane of C. atratu. scirpoidere, and others.

The beantiful selidago thyrisoidea of the lowre slopes of

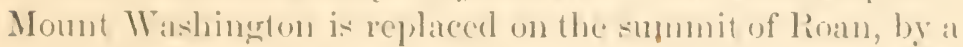

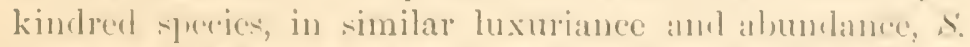
glomarata. Parongelia argyrocome, fomed only in 1 he Milley Notch of the White Momntains, oreurs on lioan only on the summit of Eiscrle C'lifl.

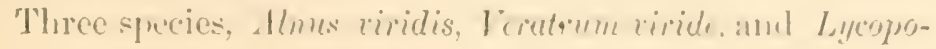


dium Selago, are found in similar situations on the two mountains, only about 1,000 feet lower on Mount Washington.

As would be expected from the flora, the contrast between the temperatures of these different mountains is very striking.

On one of my last visits to Mount Washington, July 12. the merenry stood at $36^{\circ}$, and the wind was blowing at the rate of 40 miles an hour.

While on Roan, during nine weeks from June to September, the mereury once indicated $75^{\circ}$, seven times only was it above $70^{\circ}$, once it was $45^{\circ}$, and only three times was it below $50^{\circ}$. Three days out of five the daily extremes would be comprised between $55^{\circ}$ and $65^{\circ}$.

The equability of baronetrical pressure was noteworthy; the mean height of the mercurial column being a little less than 24 inches, while the highest was 24.19, the lowest 23.57 , or a variation of only .32. The corrected mean of all the observations compared with those of the nearest station of the IV cather Serviee, at Knoxville, Temm., gave 6,391 feet as the height of the summit.

As a result of this equability of barometric pressure, was noticed an absence of high winds quite remarkable at that altitude, and quite in contrast with my experience at Mount Washington. It no time, so far as I could judge, did it reach a velocity of 20 miles an hour, and seldom more than from 5 to 10.

Nor, except in one place, was there any indication of the occurrence of a tormado in the past.

It is not surprising that this absolute exemption from leat, with the slight variation in barometric pressure should be found to give absolute exemption from "hay fever." And it is not, perhaps, beyond the limit of scientifie induction to hazard the prediction, that among these southern Ippalachian mountains and plateaus will be established many a sanitarium, loeated as regards altitude and exposure, to meet the needs of those afilicted with various forms of pulmonary, bronchial and nervous discases. 


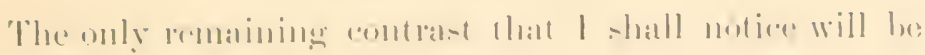
that of the -

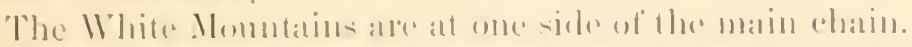

In the distance wa -

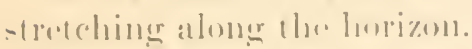

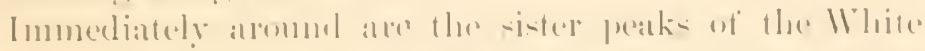

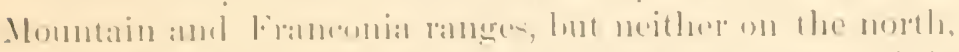

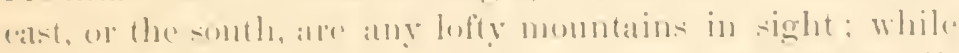
in all thase dirertions lakes pombls, rivers, and streams aliver-ify and beatutily the lamelsealpe.

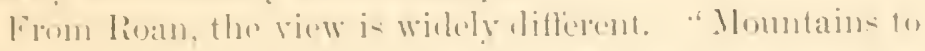

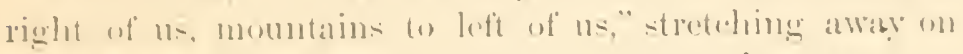
erely-inle to the horizon, momotain monalehs every one,

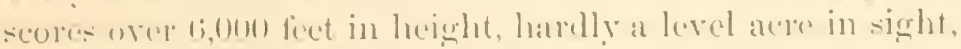

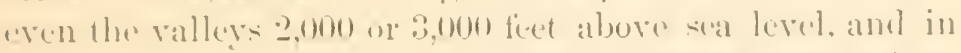
all this wile expanse, unly one little glimpse of water, where

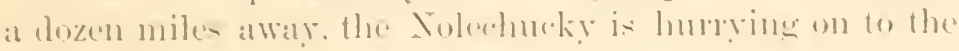
Timenece.

(1) the south we look up un the Bhate Mountain range. with Vitrhull: High leak. on which rest the bones of itintrepiel "xplorer, rising mole than $:, 000$ feet above us.

(1) the ats and somtheast the Blue Rielge is in sight with

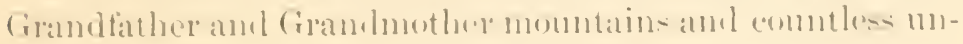
namerl preak-:

1) the north and west. He sheat platean of 'Penmesere.

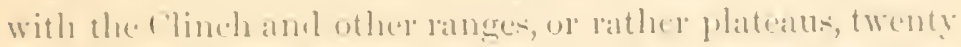

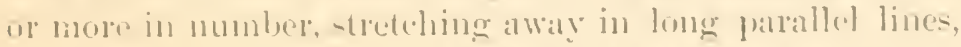
ats level as in many raildoald embankments, sometimes for

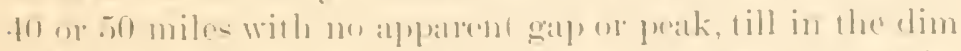

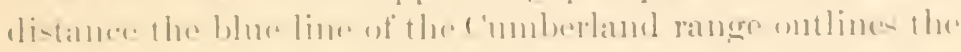
horizun.

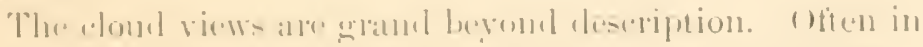

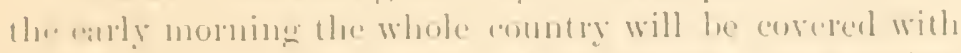

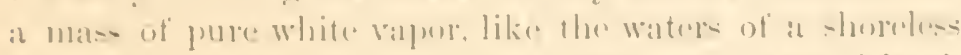

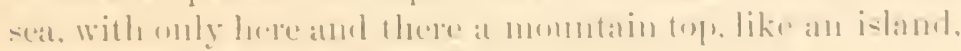
emerering from the hillows.

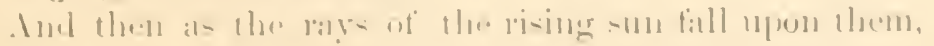


they assume tints of pink and crimson and gold, and soon with the morning breezes they melt away and the landscape stands revealed in all its freshness and beauty.

Rarely on the clearest day can you stand for half an hour ujon one of the high peaks without seeing showers and local storms sweeping over the country in rarious directions. Often several may be seen at once; not unfrequently one takes a turn and comes orer us with most unwelcome suddemness, though very often they are below us.

On two sides of the mountains, deep gulfs or ravines come nearly to the mountain top, so that you may stand on an almost perpendicular precipice and look down into a gulf from 1,000 to 2,000 feet decp, at your very feet, and see the clouds form far below, as a moist air from the ralley sweeps up the gorge and meets the cooler temperature of the upper height.

It were well if many of us, citizens of this great Republic, could look upon both the northern and southern divisions of this mighty chain, which has been for so many ages the rampart of our easten'n coast, and learn that neither section has a monopoly of nature's gifts.

It were well, if we would learn to contrast and enjoy these varieties of mountain sublimity; that there are mountains and mountains; that, as the stars, one mountain differeth from another mountain in glory.

It were well, if we would learn to study mountains, to acquaint ourselves with their peculiarities, to make them our friends, to know and to love them.

It is well for us, as scientific observers, noting all the facts alike in anthropology and biology, to note and carefully to remember that fact of all history, that mountains have not only deflected the winds and influeneed the temperature and rainfall, but have also had a powerful influence upon the dwellers among them; that patriotism has ever flourished most vigorously when nourished by mountain air; that freedom has ever loved to make her home amid mountain peaks; that "men, highminded men, who know their" rights, and knowing, dare maintain," whether in Greece, in 


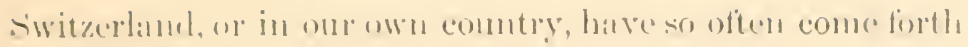
from momntain homm.

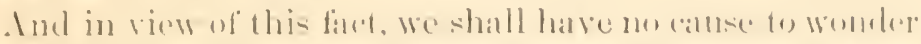
that men have forml the mountains, and in so many heats

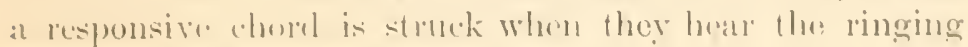

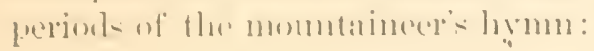

- For the strenghth of the hills we bless thec.

11u' (ixl ; utr faller's God!

Thou hast made Thy children mighty By. the toncly of the mountain sod.

The rocks yichl foumts of courige. struck forlh, as by Thy rod-

For the strength of the hill we blesis Thee, Our fiol, our father's find :" 


\section{OUTLINES OF SOCIOLOGY.}

Lecture delivered in the National Museum, Washington, D. C.. April I, I 882 by IIajor I. W. POWELL.

By organized association men live together in bodies politic. That men may live in peace, render each other assistance and act together as units for mutual protection, is the purpose subserved by organized association. In order that men may associate their conduct must be regulated. For the regulation of conduct there must be organization, and the plan upon which a body politic is organized depends upon the nature of the regulation for which it is used-organ is adapted to function.

The organization of the body politic constitutes the state.

Igain, there must be-

First, some method of determining the particulars of conduct that require regulation and the quality and quantity of the regulation required.

Second, there must be means of enforcing regulation.

Third, there must be means of determining whether conduct conforms to rule. The machinery established by a society for accomplishing these purposes constitutes government.

Yet again, there are the rules which the body politic determines to be necessary for peace, mutual assistance, protection, and the common welfare, and these constitute the law.

The science of sociology from the nature of the function: of social organization may be fundamentally divided into three subjects-the constitution of the state, the form of the government, and the regulation emborlied in the law-the state, the government, the law.

THE STATE.

A state is a body politic-an organized group of men with an established government and a body of determined 


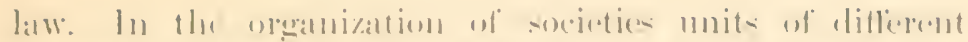

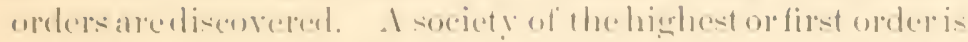

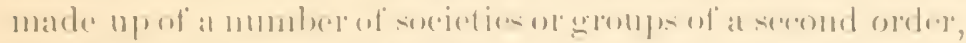

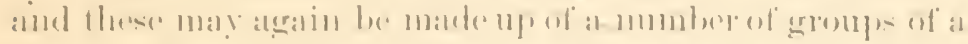

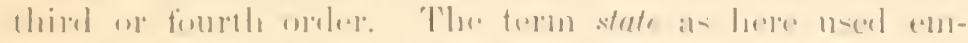

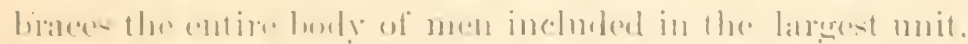

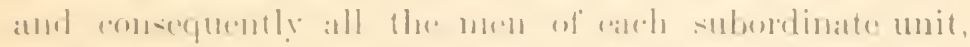

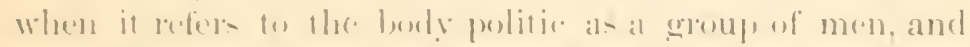

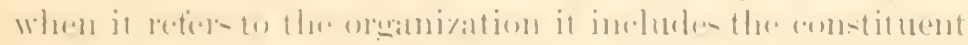

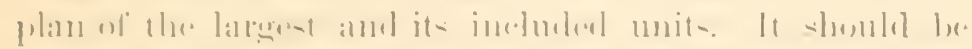

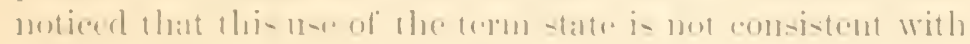

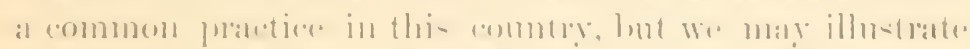

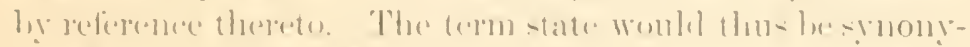

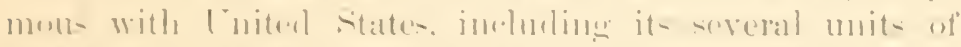

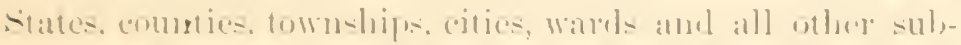

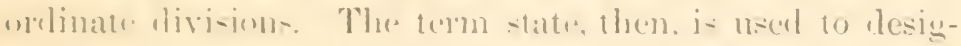

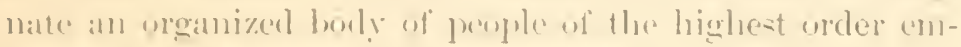

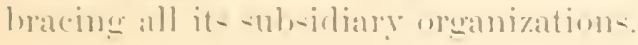

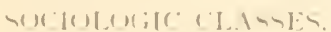

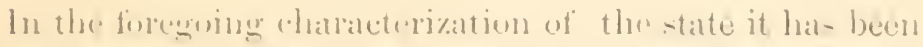
considered at a body politice oreanized for civil gorermment. that is, for the regulation of the rombluet of the individuals

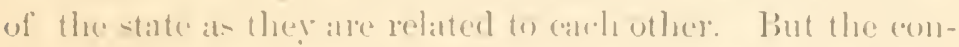
due of the mentrer of the -tate. or of the emtire boty politir, may hate relations to ether hulien politie : so that counduet must be rexulated in it=intremal relation- and $\mathrm{jt}=$ ('xtemal relitimi-.

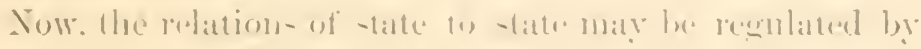
(0mmmom a rxtent. lint this regulation is imperterel and weak fiom the

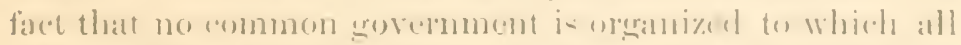

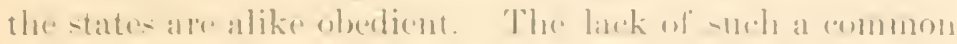

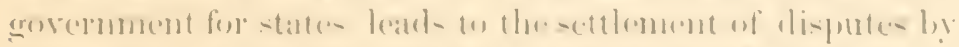

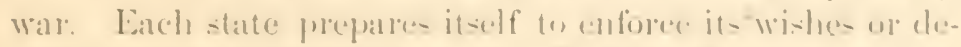

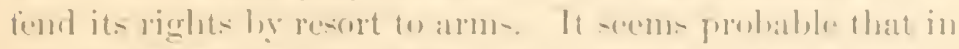

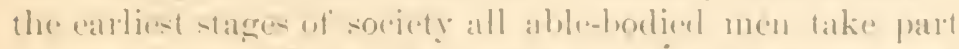

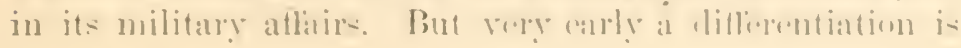


discovered by which a part only of the men belong to the army; and thus we have the military class as distinguished from the ciril class.

In all governments which have hitherto existed, human conduct has been regulated in its relations to supernatural beings. It has always been believed that the welfare of mankind depends largely or even primarily upon the will of the grods, or of one god-the Supreme Ruler of the Universe.

The relation of man to his god gives rise to religion. The conduct inrolred is religious conduct; and hence religion comes to be an important factor in determining the constitution of the state, the nature of the government. and the character of the law.

Thus in the constitution of the state we find three classes of people more or less distinctly difierentiated: The civil, the military, and the priestly class. Is these classes appear in the constitution of the state they also affect in varying degrees the form of the government, and the relations arising therefrom are regulated by lawr.

\section{SOCIAL RANKS.}

In many stages of society grades or ranks of people are discovered based upon heredity, possession of land, wealth and other circumstances giving rise to aristocracies-common people and slaves-patricians and plebeians.

\section{CORPORATIONS.}

In many states two grand classes of organizations are found-the first class is directly related to government and embraces the organizations mentioned above as grouped in different order's. The second class is indirectly related to government. These organizations serve a variety of purposes. Men are organized into societies tor religions, charitable, educational, industrial, and other ends, and such societies will here be called corporations. These organizations of the minor class, unlike those of the major class, do not constitute a part of the government, but they form a part of the state and must necessarily be 
enn-idered in the phan of the state. Whilw not a pald of the envermmont in an important way they arre comnected

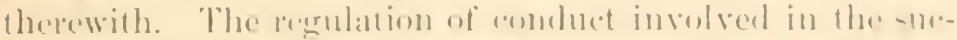

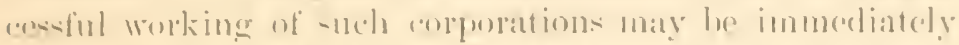

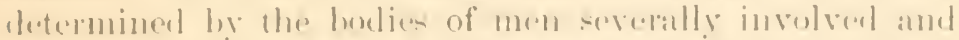

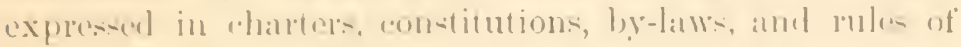

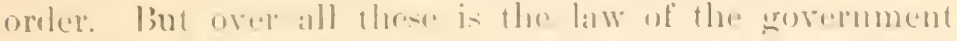

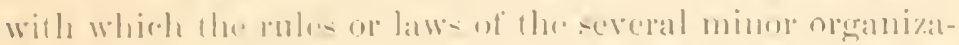
tions must comform, and for the mlimate anfurcement of which goverument is to a barge extent responsible. 'Thus we have the major and minor organizations of the state, the major and minor law of the state, ame the government of tlue tate lirevtly entoreing the major laws and indirently rnforeing the minor laws.

The seirmer alled sociology in its three great divisiomthe state, the aroverment, and the law-deals with all weranizations of the people for whatsoever purpose they may he formed.

I part rit the reculation of a state belongs to the major, another part to the minor organizations of the state, but the function of the wo rasses of regulation are not elcurly and permanenty diflerentiated. A particular sysem of regrulation may be relegater now to the government. and

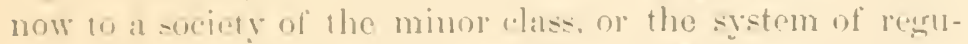
lation mas be divided between them. For example, the arrermment maty antirely antrol a system of education, or the s-ytem al enluanion may be entirely controlled by minor oceicties; or, again, a part of the educational -ystem may belong to thr gervermment, and a part to minor societics. The houndary linw hetweren major and minor regulation arre (*) shiftime.

\section{TTITE IS I PIREUS OF ORG INIZATITIS.}

In the forecroing statrument it is - $-2 x+1$ that the aramel unit of social organization, the state, is it-elf compon-ed of many minor oreanizations forming mits in a resernding seris. so that the statro has a rompoumd strueture. It also has a complex struture. Betore detiming this complexity an illustration from biologe may be in plare. 
An animal is composed of many organs performing different functions. Thus is found the brain-the organ of thought, the organ of breathing, the organs of digestion, the organs of cireulation, the organs of locomotion, and so forth. Rumning through all these organs and torming a plexus with them, are the systems of tissues. Thus we find the nervous, vaseular, and muscular systems, the whole forming a complex tissue of organs, and systems of organs, rendering the organism excessively complex in physieal constitution.

In the examination of the constitution of any particular state, it will usually be found that one system of organization permeates and pervades other srstems in such a manner that the individual state is found cxcessively complex. 'Through the series of units into which the state is organized for the purposes of government, both classes and ranks are interwoven, and through the gorermment units-the classes and the ranks-corporations are interworen.

In the Muskoki Confederacy there are forty-nine tribes, each one having a govermment of its own. But these fortynine tribes are organized in such a manner that a common government is provided for the whole. Now, the confederacy is the grand unit, the tribes are units of a second order. But the clans of one tribe are also the clans of another, so that each "lan is distributed through many tribes, and each clan has a government of its own, subsidiary to the government of the tribe, and again subsidiary to the government of the confederacy. The organization for a clan is woven through the organization for a tribe in such a manner as to make the constitution of the state complex.

In those states where the organizations which we have here called corporations are highly developed, the corporitions themselves render the constitution of the state complex. Church organizations do not run parallel with state lines, but extend their operations and their control over their own members regardless of political divisions.

All states that have been studied have been thus found, both compound and complex. Such are the essential characteristies of the social organization of mankind into states. 


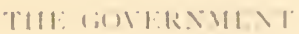

The diflerentiation fom the statent an wrantwed -ystem

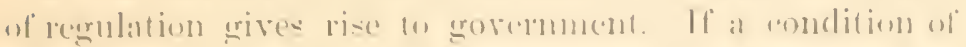

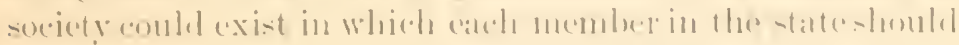

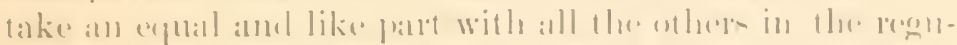
lation of (o)

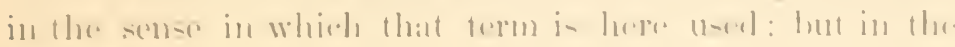

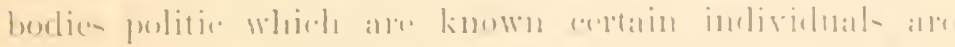

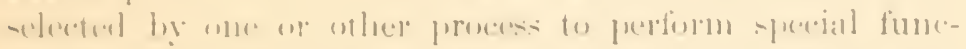

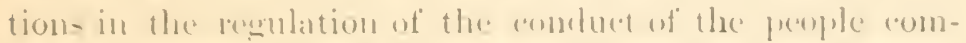

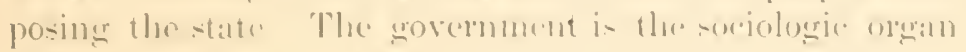

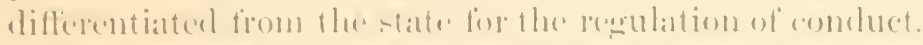

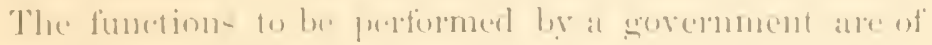

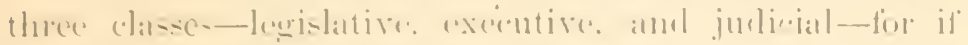

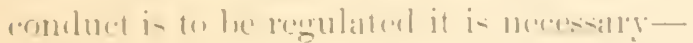

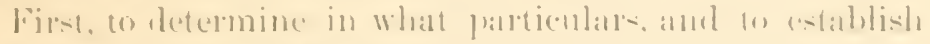

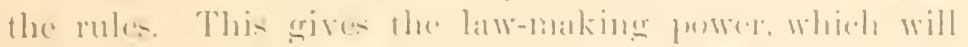

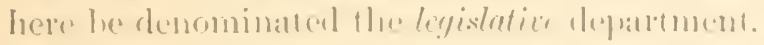

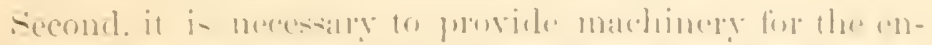

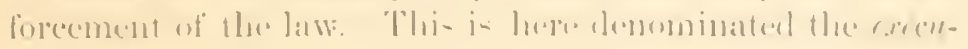
tive slepormentent.

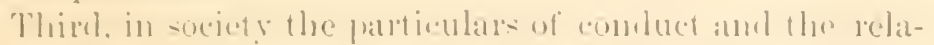

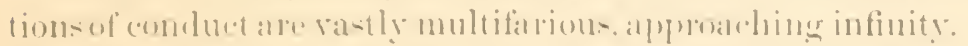

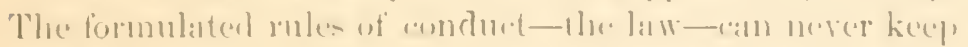

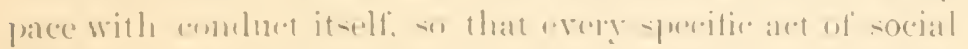

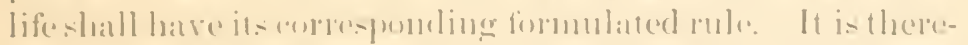

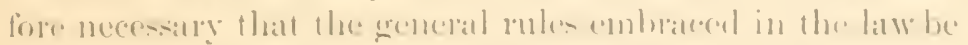

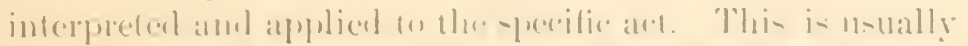

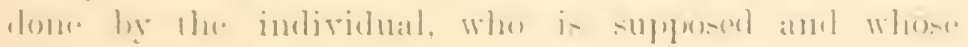
luty it in, to kmow the latw- of the -late ; but the imblivilual

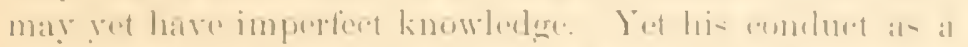

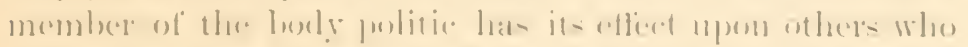

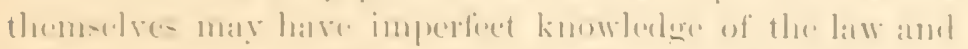

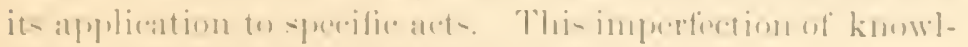

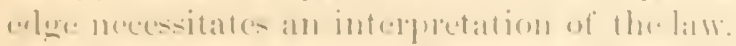

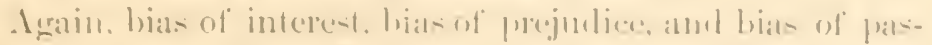

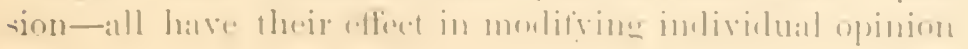


relating to the law. Under these circumstances, it is found necessary for the state to devise, as a part of its government, some organ for the interpretation of the law in its application to specific acts. This gives rise to the judicial department of government.

These three great functions have never been clearly differentiated in the organization of a government; but the distinctions have usually been perceived and a partial differentiation of organs is ever found.

In the constitution of the state, it has been seen, three grand classes arise-the civil, the military, and the religious. Wherever in the state such classes appear, the form of government is adapted to the regulation which the constitution of the state demands, and in this manner the functions of government may be classified as civil, military, and religious-the military gorernment inhering in the army, the religious gorernment in the priesthood-and armies and friesthoods are constituent parts of such governments.

Usually in all stages of society, military government is entirely subordinate to ciril government, but there are times in the middle stages of society when the military govemment assumes inordinate proportions, so that the civil government becomes subsidiary thereto; but such military governments performing ciril functions are ephemeral.

Again, in the constitution of the state, religious organizations invariably constitute an important factor. In the lowest tribes a priesthoor is a part of the government. In certain stages of society a priesthood sometimes acquires inordinate powers, and ecclesiastical or religious governments are organized; but such governments arise only occasionally and are ephemeral.

In the constitution of the state two classes of organizations are found-those relating directly to the government, called the major organizations, and those relating indirectly to the gorernment, called the minor organizations, or corporations, and each corporation develops from its own body of members a government of its own, through which, in frart, it is related to the government of the state, and to 


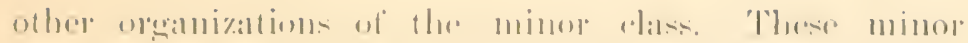

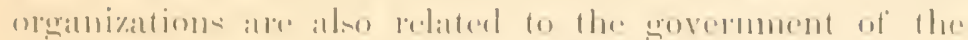
state, and to ratels oflere directly thromeh the individnals of which they atre antomposed.

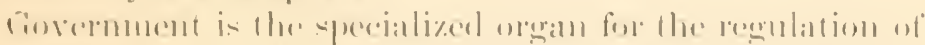

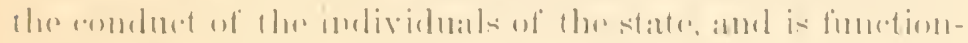

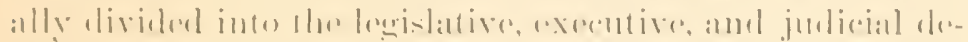
fartmonts, with a still torlher fumetional division lomming

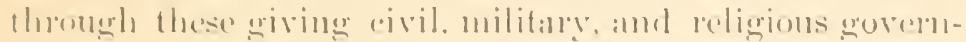

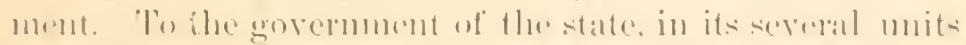

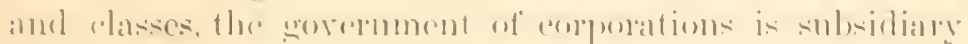
and ulumlinut.

WII: 1.AW

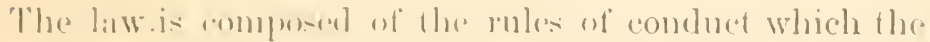

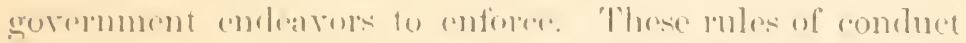
(ontrol the individuals af the state in theje relations to rach othere. ('omburt, in its relation to the indiviluals imvolved.

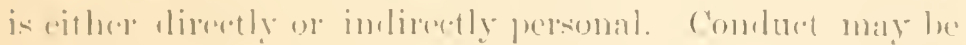

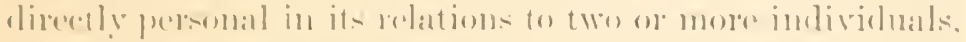

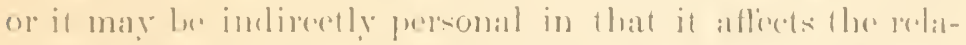
tions of the individust thromgh the molimm of property.

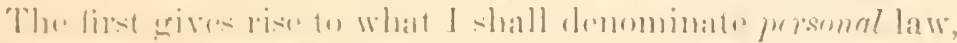

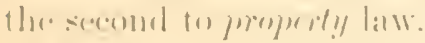

Again, in the meanization of the bouly politice minne

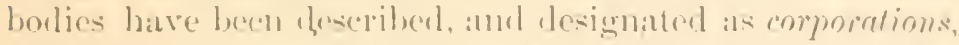

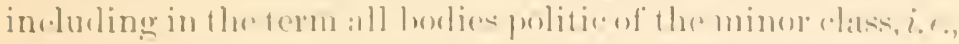

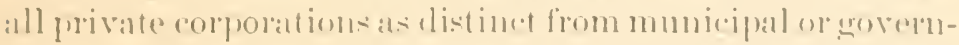

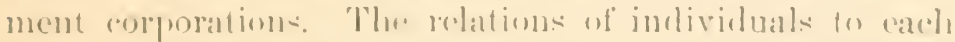
nther, as members of a corporation, arre confrolled hy 1hr. (o)

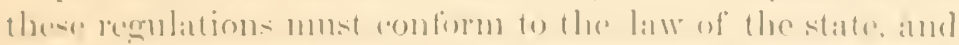

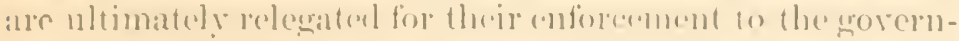
ment. But the eontrol of rorporations in their relations to

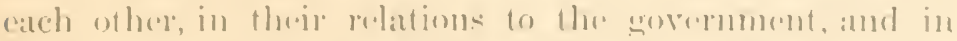
their redations to the imdiviluals of the state griver rise to a bonly of enepuration law.

Igain, since govermment is diflinemtialtel as the organ of 
regulation. the organ itsult must be controlled-the conduct of the government must be regulated. This gives rise to what I shall denominate goecrnment law.

It has been seen that the conduct of a state, and of the individuals of a state has relation to other states. The rules for the regulation of this conduct wives rise to international law.

I. no common govelnment exists betreen states to enfore international law, armies are organized, and for the legulation of their conduct military law is dereloped.

The conduct relating to the relation which exists between men and deity wires rise to the organization of ecclesiastical bodies. For the coremment of these bodies, and for the enforcement of the rules of conduct which religion imposes, religious law appears.

The law. then, which is the body of rules which the state endearors directly or indirectly to enforce, may be properly classed. as follows:

1. Personal law.

2. Property lari:

3. Corporation law.

4. Government law.

5. Interuational law.

6. Military law.

7. Relisions law.

In addition to thi- . Mssification of law on the basis of the particulars of conduct to be controlled, another fundamental classification is found rumning through and interworen with each of the others. This classification depends upon the method by which regulation is accomplished. Ciencral rules of rombluct are established, and these general ru'es are applied to specific acts. Thus duties and rights, or rights active and passive, are determined. Usually, to these rules determining rights, the individuals of the state conform their conduct; but to an important extent they do not. To the extent that conduct is conformatory to the law, right is done; to the extent that conduct is 
not in conformity with the law, wome is dome. Sow, grov-

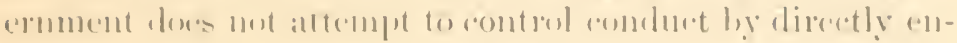

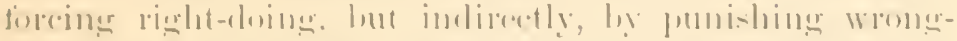

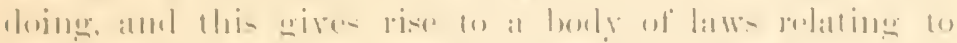

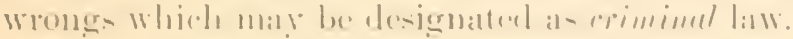

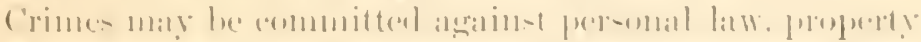

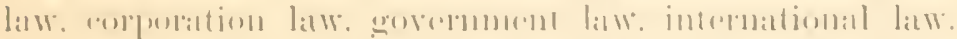

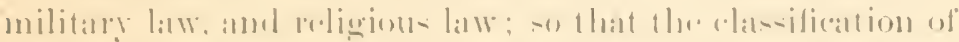

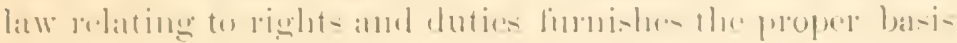

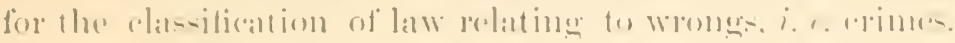

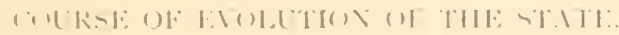

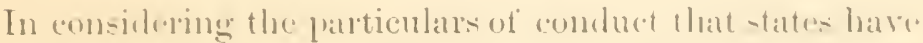
attempterl to regulate we lind they can be clas-ifient on still another basis than that presented in considering the subject of law. Comduce may relate to the prepetuation of the species, or combluet maly relate to the wellime of the indivilual. Though this elasification serves no inportant

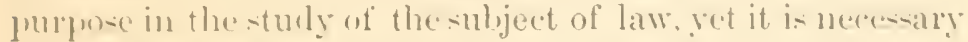
in rensidering the constitution of the state and the form of the gevermment)

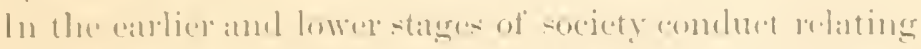

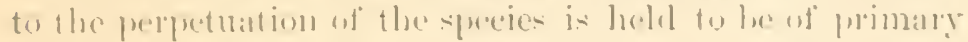
impurtane. While enmeluet relating to the welfare of in-

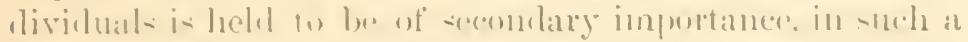

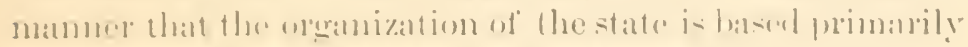

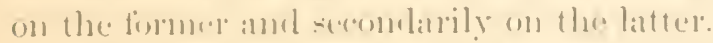

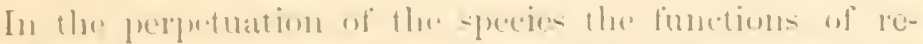

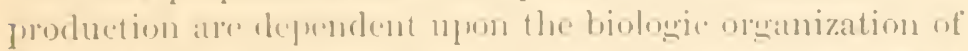

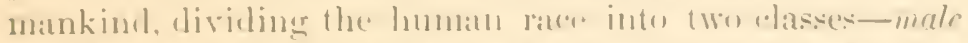

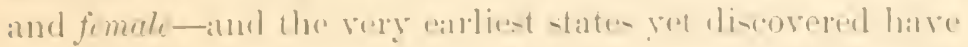

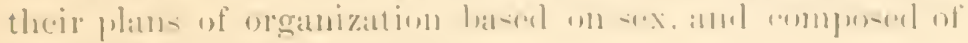
clas-ilied borlius of kindrent

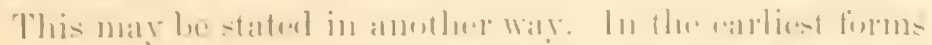

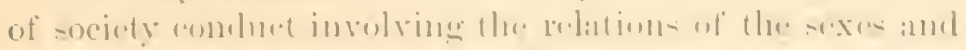

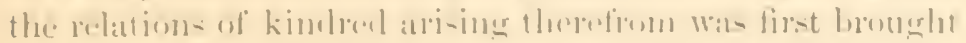
muder remalation. The primary amel principal =omree of

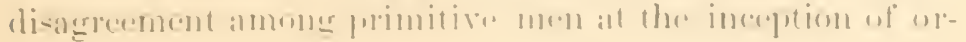


ganized society grew out of their clesires for the possession of women. Men first canle into conflict with each other on account of women, and to live together in peace it became necessary to organize government and enact law regulating marriage and kinship relations arising therefron.

The government and the law relate mimarily to kinship, regulating the relation of the sexes, and the relation of the sereral member of bodies of kindred; that is, the state is organized on kinship. Gorermmental functions are performed by men whose positions in the government are determined by kinship, and rules relating to kinship and the reproduction of the species constitute the larger body of the law. The law regulates marriage and the rights and duties of the sereral members of a body of kincled to each other. Individuals are held responsible only to their kindred, and certain groups of kindred are held responsible to other groups of kindrerl. When other conduct, such as the distribution of game taken from the forest or fish from the sea is regulated, the rules or laws pertaining thereto involve considerations of kinship, and this is extended so far that a large body of rights to property are kinship rights. In this manner all the earlier forms of the state of which we have knowledge atre batsed on kinship. This gives us kinship society and tribal government.

In the highest forms of social oromization discovered in the nations of civilization the regulation of conduct discorered in the govemment and the law, relates chiefly and primarily to the welfare of the individual, and secondarily to the perpetuation of the srecies: and of the conduct relating to the welfare of the individual that which relates to property bas an overwhehning predominance.

Tn the arliest stages of society small wealth is accumulated, and industries for the production of property and wealth are compratively moleveloped. In the higher stages of society greatly alcumulated wealth is found, and industries are differentiated and industrial orgmizations multiplierl beyond all others. As therefore the oreans of government must be adapted to its finctions, the plin of 
govermment in such a state must he hatsel uperi property. Thus property, sociely, and national sovermment alre constiturter.

In kinship states the fundamental relasification of the

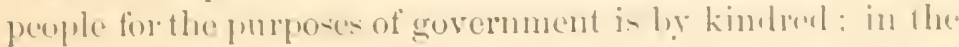
property - sate the fimblamental classification of people for purposes of enovernment is by territory. betwerne these stages-thr lowes and the lighte-t-many intermoliate forms ane fomml. Do lamel and last lines ean bo drame A clear distinetion can be marle only between the lowes and the highest. smrivals ol kinship socicty exist in all gorermments where position, i. e. oflice, in the govermment is hereditary, and property souety with the gurerment of the

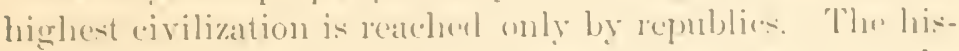
tory of the constitution of the state is the histery of the evolution of kinship society into property society.

There is yet another way by which this evolution may bx eharacterized, namely, by the prowresing diflerentiation of the organs of the state, and by the progressing integrationof states.

The diflerentiation of organs in the -talte is represented in thre" waty-

First. l,y the multipliation of organs ot governument-as

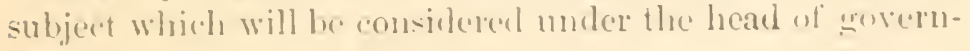
Incint :

secomel, by the multiplieation of the orelers of muts and the specialization of the sulurdinate mits so that -mbereli-

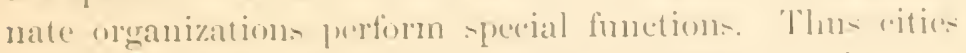
may be divided into ward-. entuntion inte town-: and

Thirel, he the multiplication of corporations for -pecitie

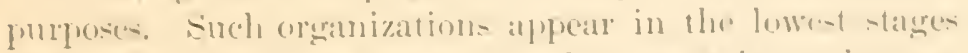
of society only in a crude form, but as sordety anlvances they are perfected, and greatly multiplied, muil in modern civilized society a -late leeromen a vast plexus of arplurittions.

In the carlice stages of socioty catch stalle in small, luoing composed only of a borly of kimlmed by comsingminity and aflinity, actual or artificial. I- carle state is small man!

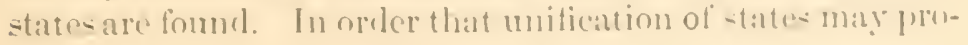


gress organization by kinship must wive way, and gradually it does give way, to be replateed hy organization on a property hasis. Organization on a property basis appears in many wars, but chicfly in two-first, captives in war and other persoms are made slaves, and become property themselves: and, second, a palticulal form of property-landgradually eomes to be of prime importance and is at last taken as the basis of the primary classification of the state, which is territorial.

By varions processes of alliance, by confuest, by development of fentalities, and by savery, states are integrated, and by the development of the organs of govermment and private corporations, the classes of the state are difierentiated, and with this the plan of the state is changed from a kinship to a property basis.

COURSE OF EVOLUTION OF GOVERNMENT.

The carliest form of govermment of which we hatre knowledge consists of an asscmbly composed of men, from which are excluded all deemed too young or too old to exhibit due wislom. 'This assembly is the law-making power, $i . e$, the legislature, and the law applying power, $i$. e., the court. It is, in fact, the body of able men meeting to confer and decide upon conduct, and is essentially legislature and judiciary undifferentiated. This assembly has a presiding officel who obtains the position by (*)mmon consent or formal choice, and who sometimes acts as an executive officer in carrying out the decisions of the assembly. But this crecutive power, though it may sometimes, does not invariably inhere in the presiding officer.

sometimes, and perhaps usually, the executive power is delegated to a committee of the assembly. The committee may be aplointed temporarily to carry out a specific determination of the assembly, or it may be a standing rommitter to carry out a class of rleterminations. The form of government thus described probably exists at present in some of the tribes of Australia and elsewhere, as such accounts are given loy travelers and students of ethuol- 
ogy ; but these ancounts alre incomplede, and latre been

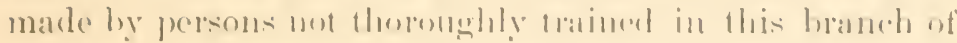

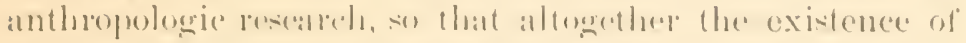

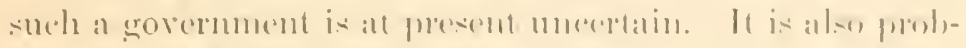
able that this form of govermment has existed in past timms

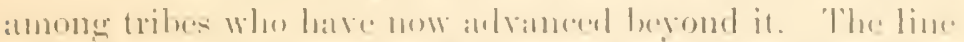

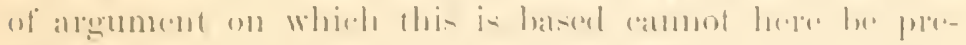
sented, and it i- lint lair to sily that positive enolusions

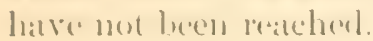

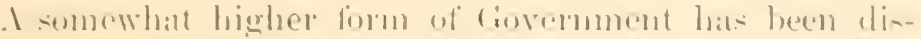

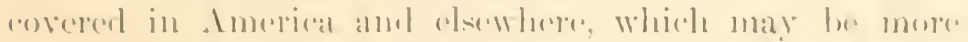
thoroughly deseribel. In this the assombly of the people. is more definitely organized. The presioling ofluere is formally scelected, and his temure of office i- for life, unlensther-

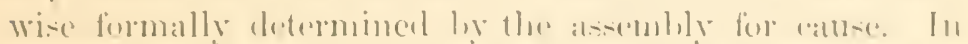

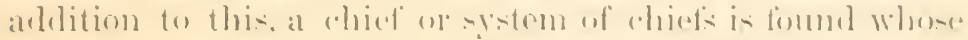

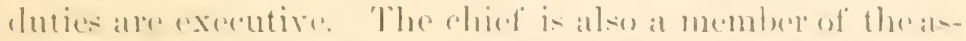
sembly; hut is not a chiet by virtue of such memher-hip lut

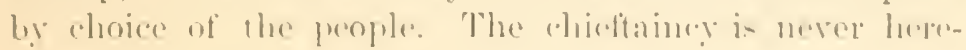
ditary.

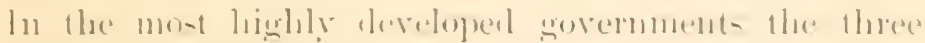

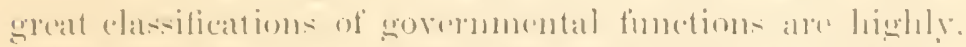

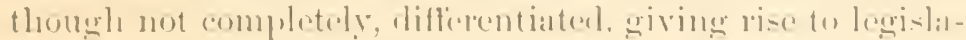

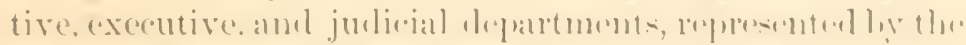
assembly, the ruler, and the ermit.

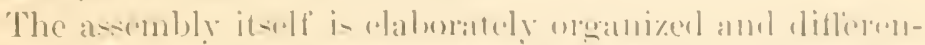
tiated into two or more eorelated divisions. Fesentive

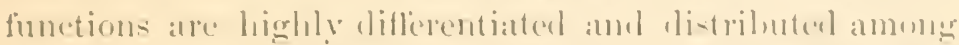

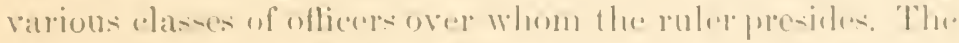

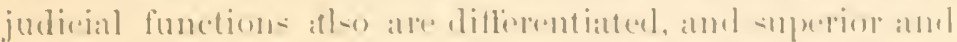
sulurlinalte (o)

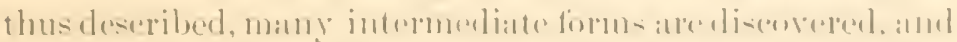

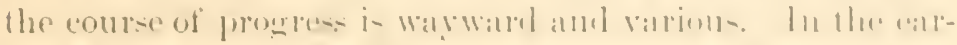

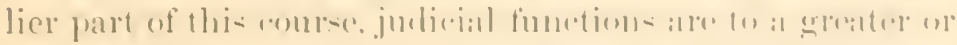

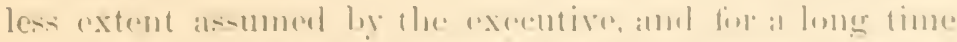

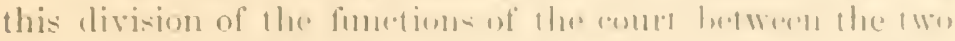

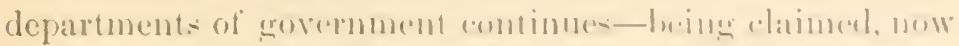

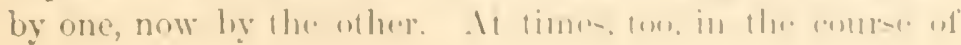


progress, legislative functions are assumed by the executive department, and a conflict is waged for supremacy. At last, by various processes, the court is organized.

Three of these processes must here be mentioned. As states increase in size the business of adjudication becomes so great that proper attention cannot be given to the multiplicity of cases arising. Under these eiremustances committees of the assembly are appointed with judicial powers, at first extremely limited but gradually enlarged, until courts are developed. On the other hand, where judicial power has to a greater or less extent been assumed by the executive department, the rulers find themselves overwhelmed with business and appoint subordinates in the first instance to adjudicate specifie cases, but gradually the powers of these subordinates are enlarged, until courts are thus established.

Again, ecclesiastical bodies claiming superior virtue and wisdom sometimes assume to adjudicate, but such adjudication is gradually relegated to specified officers of the body, and thus ecclesiastical courts are developed.

The courts originating from the assembly from the ruler and from the ecclesiastical body alike, may be more or less multifarious. When they spring up in the same state their jurisdiction is at first imperfectly defined. Each strives for supremacy, and thus jurisdiction orerlaps jurisdiction. This conflict ultimately results in the organization of a system of courts integrated in a superior court, and differentiated by the establishment of a variety of inferior courts with jurisdiction more carefully defined-the function of the inferior courts being controlled and restricted within proper bounds by appeal to the superior.

Thus, at last, the functions of the primitive assembly, originally legislative, executive, and judicial, are differentiated, and the legislature, the ruler, and the court are established.

THE COURSE OF EVOLUTION OF LAW.

In the development of the tribe into the nation, conduct develops from extreme simplicity to extreme complexity, 
and for the regulation of rembluet the law mu-t likewi-e derelop.

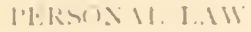

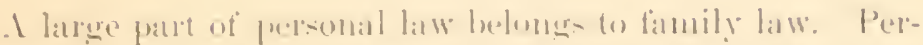

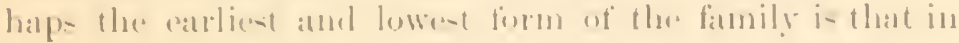

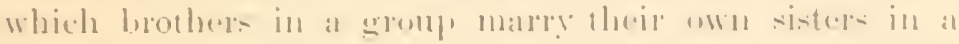

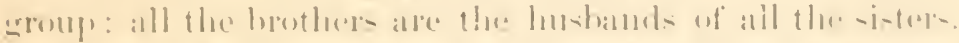

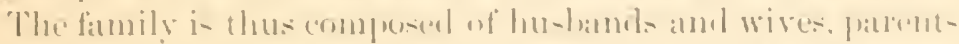

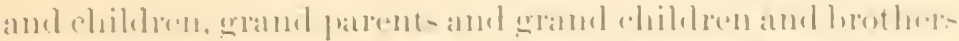
and sisters. ( oblateral lincent kinship are not establisherl.

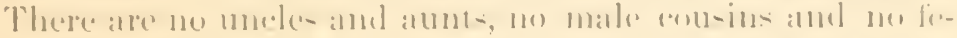
male cousins, and no nephews and noice. This is known a- the Punaluan family or system of kinship.

Inother form, kmown as the Malalyan fimily or sy-teme of

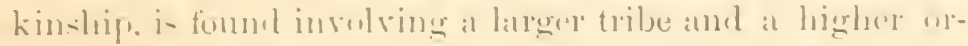

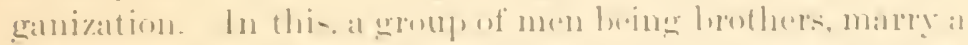

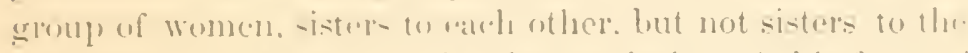

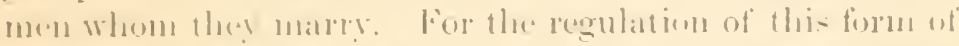

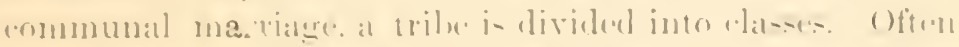

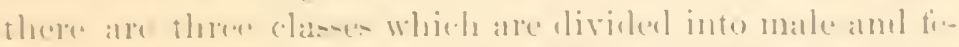
male-making in all, -ix. Lut thes lu reperented ly lat-

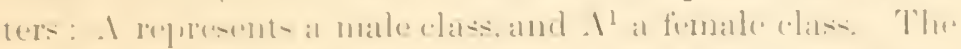

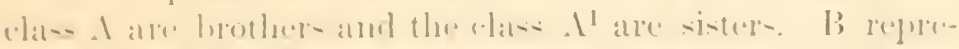

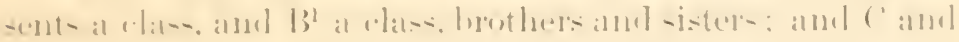

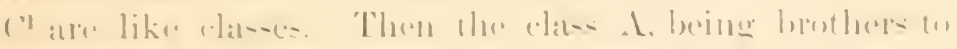

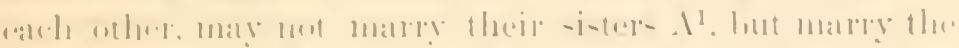

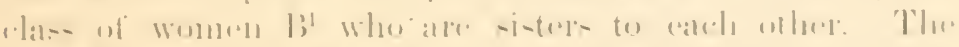

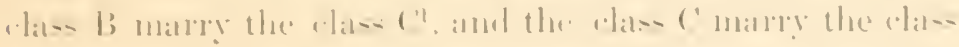

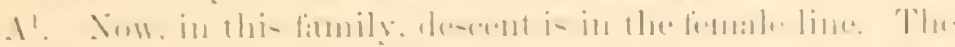

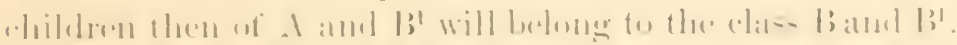

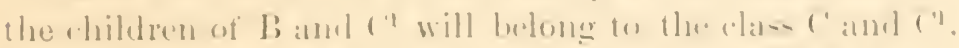

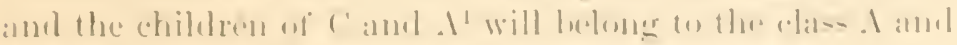

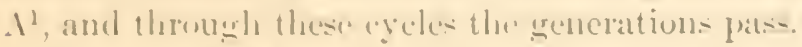

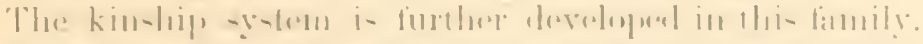

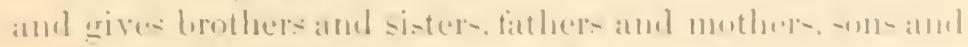

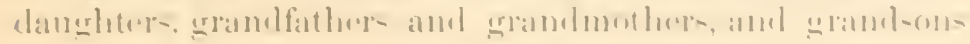


and daughters. It also gives aunts and uncles. 'The children call their father and father's brothers, all fathers, and their mother and mother's sister's, all mothers; but their father's sisters are aunts, and their mother's brothers are uncles. The children of their father's brothers they all brothers, the children of their mother's sisters they uall sisters; but the children of their father's sisters they call cousins, and the children of their mother's brothers they call cousins.

This family is widely spread in Iustralia and elsewhere and the kinship system is still more widely spread as it exists among all the tribes of North and South Inerica and elsewhere in Europe, Asia, and Africa, and in some of the islands of the sea.

The Punalnan system of kinship at first described is known to exist, but the form of communal marriage is not known. The Malayan system of kinship and marriage is known.

The simplest and most common form only las been given.

The development of this into the polygamic and monogamic systems of marriage is accomplished in diverse ways among many tribes. The group of husbands and group of wives constituting one family comes to be very large and narrower restrictions are adopted, thus boys of one mother will be married in a group to the daughters of another mother, and various other restrictive regulations will appear, but all involving a common principle, namely, that the husbands and wives have no choice. Selection is made by legal appointment. Legal appointment develops into individual selection through three processes:

First, the parties interested consulting their own wishes, elope; and marriage by elopement though illegal at first, is made legal on the day of jubilee. This procedure widely prevails among the North American Indians.

Second, it oftimes lappens that in the vicissitude of life certain groups of families of sisters increase in number, while the group of brother's to whom they belong decrease in number, and vice vers. Under these circumstances a few men are entitled to many wives, and the law holds this 


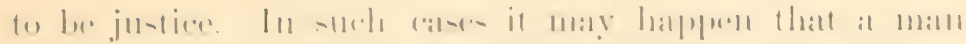

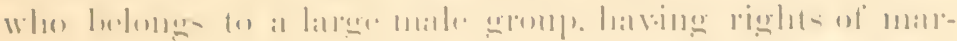

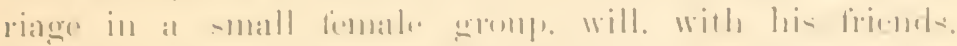

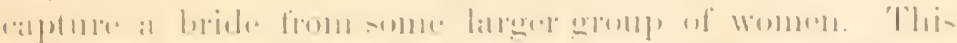

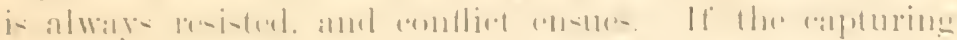

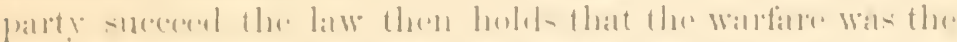

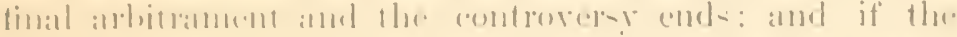

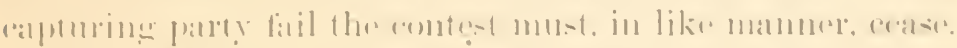

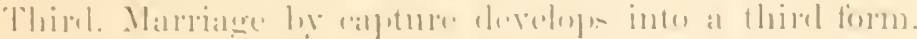

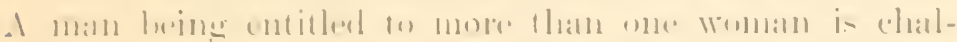
leneerl he a man whe he the vire-itmles of life and

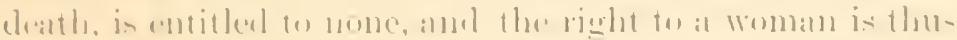

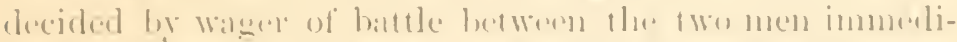

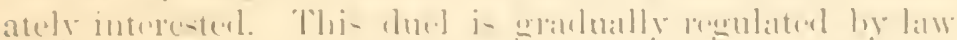

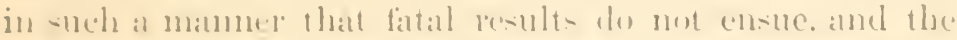

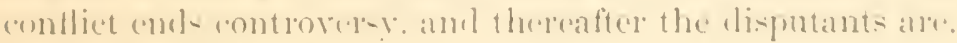
themsarin. friends.

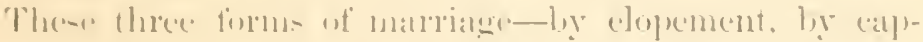
ture. and hy duel. are aralually regulated, and come to

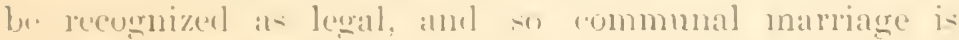
dovelopred into polyganic anel monogamic natriage: and

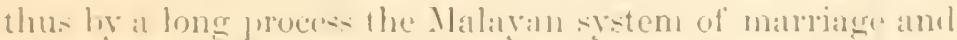

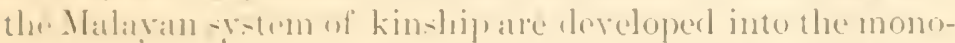

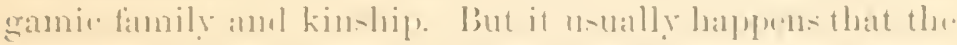

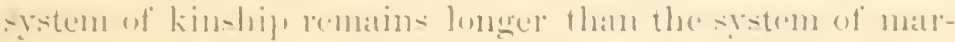
riage. that is. the erolution of language does not kepp patee

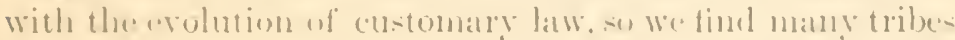

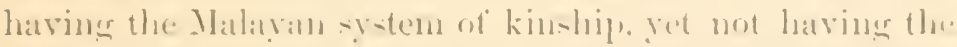

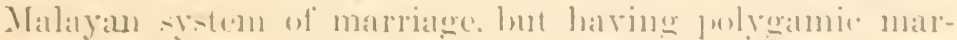

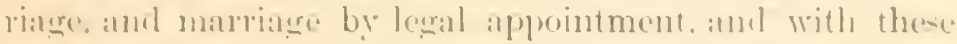
marriage by apement, by apture, and hy durl.

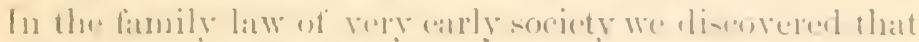

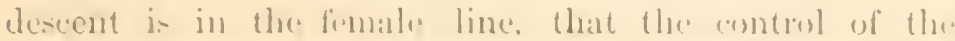

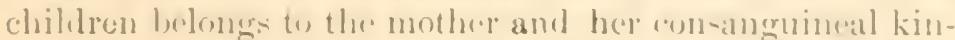
dred, and that the father and his kindred have ne control orer the famils. 'lhe hashand is hut the ente-t of the wif. and hrer friends.

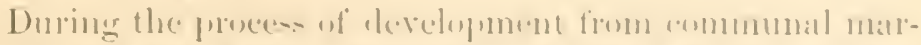
riage, and the system of kinship, involved, to monegande 
marriage and its system of kinship, a change from descent in the female to deseent in the male line oceurs, and with this change the control of the family is relegated to the husband and father, and rapidly this control becomes absolute, amd the patriarchal family is established, in which the father has power of life and death over his wives and children and all their descendints, but gradnally this power is regulated by law.

A method by which descent is changed from the female to the male line, that is, by which mother-right is changed to father-right, appears among the North American Indians.

When the gentes of which a tribe is composed do not live in a compact village but are spread over a large area of country, so that each gens lives alone separated by miles of distance from the others, the consanguineal relatires of the wives, who are the guardians and masters of the family, are not present and cannot exercise control. Under such circumstances authority is gradually assumed by the husbands and the line of descent is ultimately changed. There may be other methods by which this change is made.

PROPERTY L.IIV.

Property law is naturally divided into two classes-property in chattels and property in land.

To a large extent in primitive society chattel property is communal-owned by classes or clans, but a few articles, such as clothing, ornaments, some implements and utensils are owned by individuals, yet no large accumulation of these things is permitted to the individual. Under these cireumstances barter and sale are clogged because individuals cammot freely exchange-the consent of two bodies of personis being necessary therefor. As industries are differentiated, that is, in the first beginning of the differentiation of labor, articles are exchanged by regulation-the price is always the legal price. Inheritance is by clan, not from parent to child.

In the progress of social organization communal chattels become personal property. Inheritance by clan gradually becomes inheritance by nearest of kin, and, finally, wills are 
invented, and inheritance by designation of the owner is developer. Then with the derelepment of money, harter

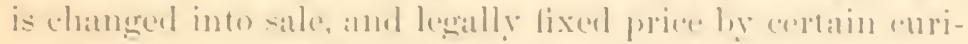

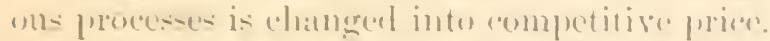

lu the mo-t primitive socicty the latul is hele lig the

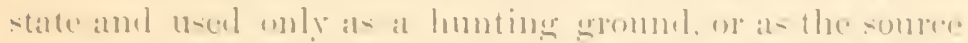

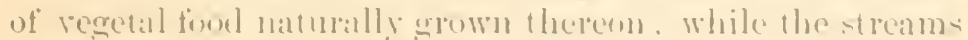
and coal-ts ale heh] as fisheries: hut where rucle eultivation

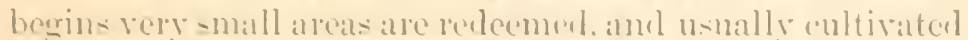
land is helel lix trilu or elan. Thus, temme to anltivated

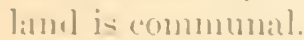

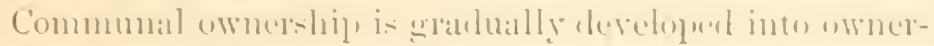
ship.in severalty by a valiety of proceses intresting in

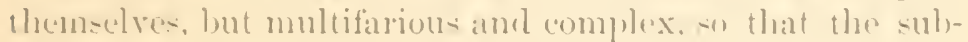
jeret may not here le treated at larese

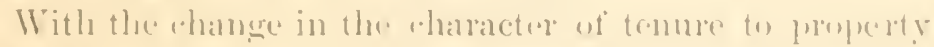
from communal to indivilual ownership, there grow-11) a lare body of law relating to contract.

[The consinleration of the evolution of corporation law is omitted.]

\section{GOVERNIHAT I. IW}

In lower trilue government law comsists of a few -imple

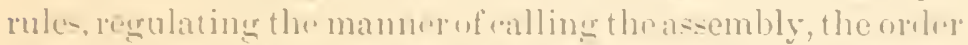
of elelileration, and the methoul of announcing the derision,

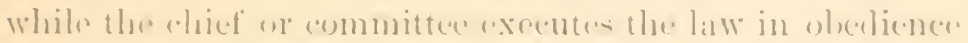
to a few expally -imple rules. In higher nations, where the lori-lature, the ruler amel the (enut appear, govermment law is greatly elaborated. 'Thu logislature is organized by

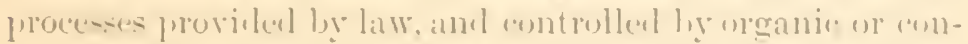

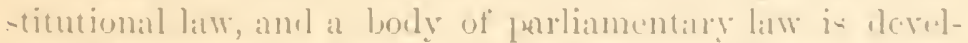

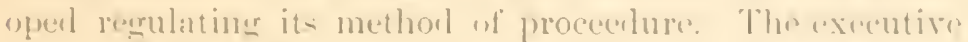
lepratment is eroverned by orannic law, by law emana-

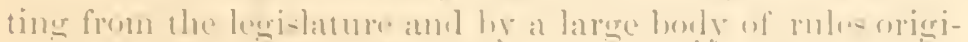

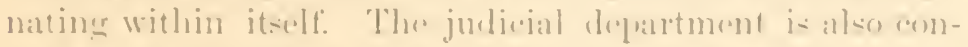
trolled by oreande law, ly dimetory laws emanating from the legislatmre, and by the rulas of the entrt. imvolving at

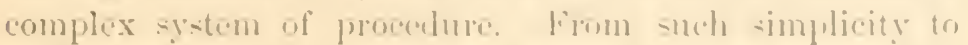

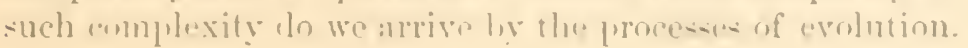


CRIMINAI, IAW.

Of erimes resulting fiom the regulation of the relations of the sexes, marriage within the preseribed group is held to be the most heinous in primitive society. It is nerer condoned, never compounded. Inficlelity after marriage may be condoned or compounded.

Crimes relating to personal injuries include murder maiming, and slander. Murder may be punished by the taking of life-not neceswarily the life of the murderer, but one of his clan. but murder may be compounded and primitive law fixes the value of individuals according to sex and rank. Murder may be atoned for by substitution, that is, the murdered man may be expatriated, driven from his family, and thus become dear to his own people, and then he may be adopted by the injured family and made to replace the murdered person. Thus the wife of the murdered man may adopt the inurderer for her husband, and, in $s$ doing, he loses his own name and all relations of kinship, and accepts the name and kinship relations of the murdered man.

Maiming is punished by maiming-" an eye for an eye and a tooth for a tooth "-and maiming may be compounded, and the value of the several parts of the body is specified by law.

Slander is punisher the sane as the crime alleged in the slander, and slander may be pleaded as a justifying cause for nurder and maiming; slander may also be compounded.

In primitive society by far the largest body of erimes is included under the practice of witehcraft, and this is terribly punished. Abnormal conditions of body, aberrations of mind. and infelicities of temper are all interpreted as evidences that the possessors thereof are uneanny people, and to a large extent deafiness and blindness before old age from (aluser that eannot be readily understood, and all loathsome or strunge diseases are likely to be attributed to sorcery, so that the practice of witcheratt is everywhere believed in, and witehes and wizalds are multiplied. Witcheraft is punished by death, but after conviction in the court, ap- 


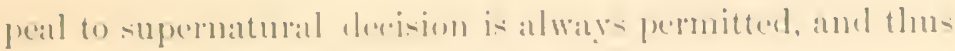
We have the erigrin of trial by meleal.

[ 'riminal law in the higher stages of -exelety need not he

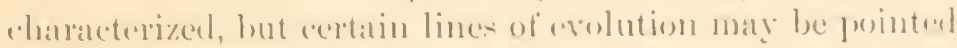

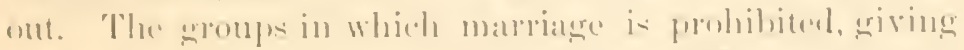

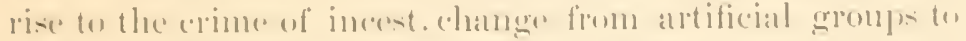

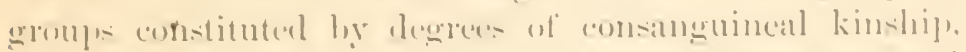

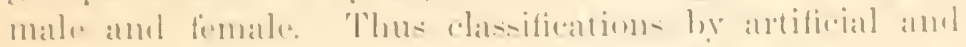

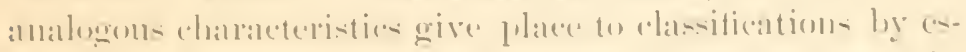

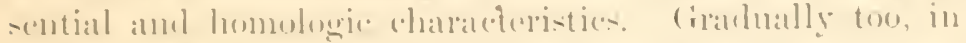

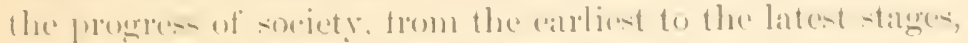
the motive of the mumesere is considered, and alceilental killing and maiming are diflerentiated foum willful mureler

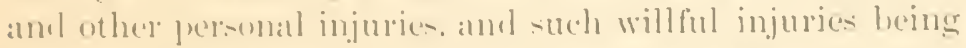

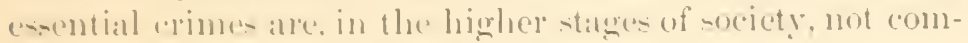
pommlinl or atomed for hy sulstitutiom.

Inthe crimes which come from the unlaw ful acquisition ot property the punishment hy multiple restitution fomm in the lower stattes is superseded he fines which go to the state and hy impuriomment. In the lower stager uf society froperty "rime alle thefts; in the higher stagen, property crimes alle thefts and fraturl-.

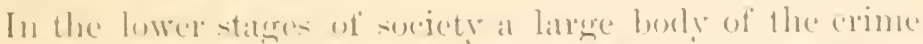

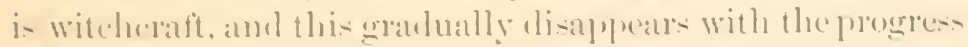
of culture. It should be moticed that in early soricty there

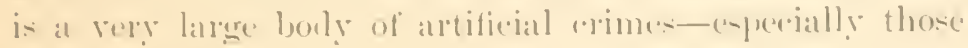
relatiling to - rerery.

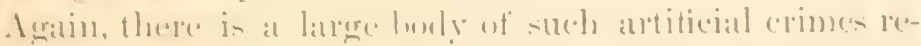
latimg to ger-emal injuries, from the fact that willful injury

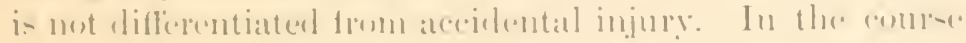

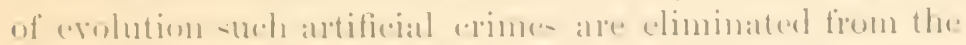

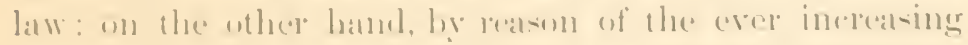
romplexity of the relations of mon, the elas=-e of real rerimes are multiplierl.

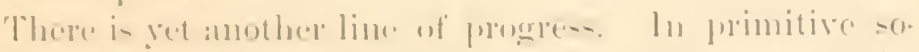

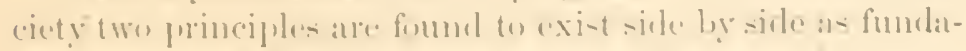
montal theoricis in the arhainistration of the law.

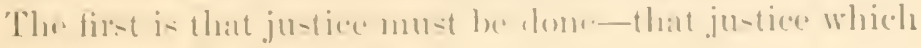

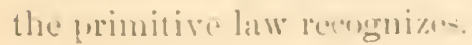


The second, that there must be end to controversy-that peace may prevail and society be not disorganized; and this must be accomplished though the former fail.

To secure end to controversy, there is resort to two methods-

First, days or other periods of jubilee are appointed at which all crimes, except murder and incest, a forgiven. In the lowest societies it is a day of jubilee, coming once a year'; in the highest societies, it is a year of jubilee, coming at longer periods. With progressing society this method of cnding controversy is adopted in the case of crimes which are manifestly artificial in the state of culture to which the people have arrived, and by this means willful murder is at first differentiated from accidental killing.

Still another method of terminating controversy and avoiding punishment for artificial erime, is provided for in the establishment of cities of refuge.

Now cities of refuge come to be such in a curious manner. In the early history of mankind, cities are states and autonomous; one state does not punish the crimes committed in another; and men committing crimes flee from their own states to others, and become incorporated therein by adoption, and thus secure immunity from punishment.

When on the first organization of nations, two or more city-states are consolidated and placed under one general goverument, certain cities often remain as places of refuge, but with an important restriction, namely, that the crimes belong to the classes which have been here described as artificial.

Thus days of jubilee and cities of refuge are important agencies in the evolution of criminal law.

The growth of law in its entire course is governed in many important respects by the theory of the origin of law and the source of its authority. This subject involves the discussion of the erolution of philosophy and cannot now be undertaken. It is the highest and most important subject with which the mind of man can grapple, as it involves the whole theory of human conduct-the ethics of mankind. 


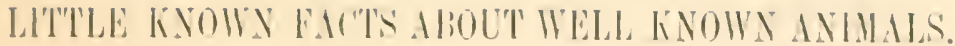

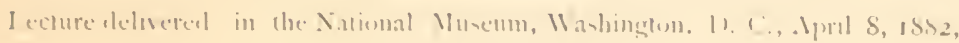

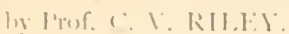

1.11011: 1.011 (i1:N11.1\%1\%:

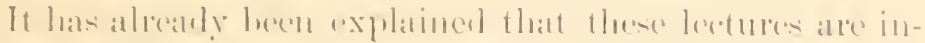

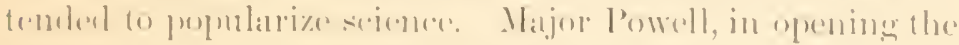

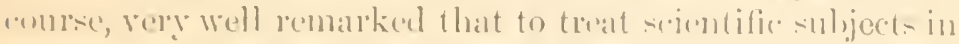

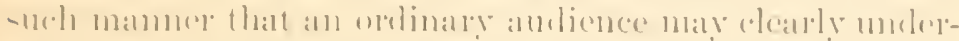

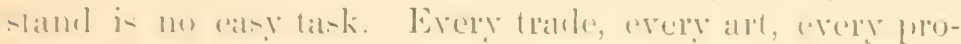

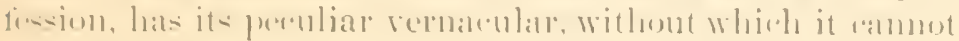

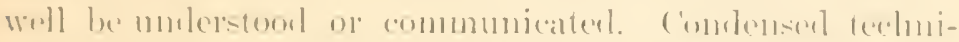

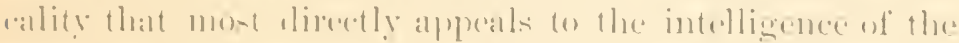

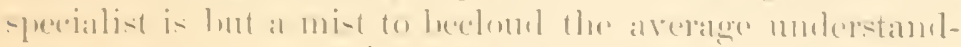

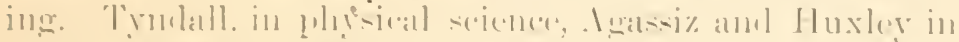

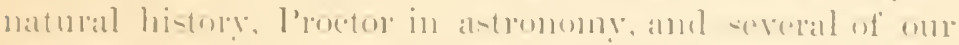

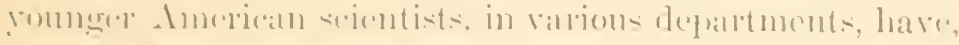

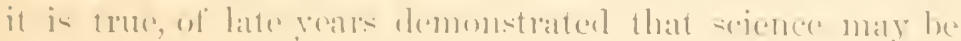

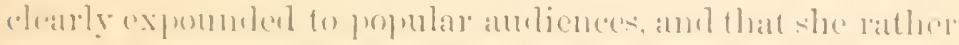

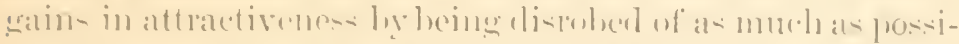

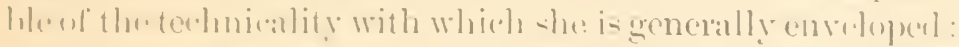
lut theil s) technical touls of the mulerstamblimes.

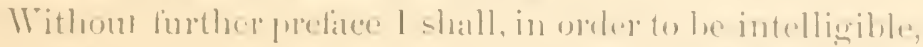
rhoose as suljerete for my remalle a fow animals with which

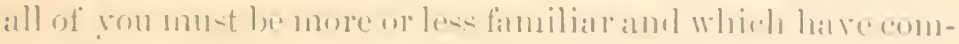

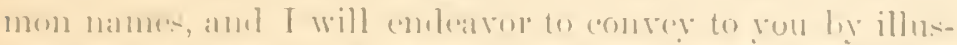

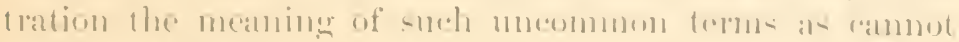

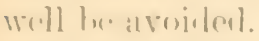

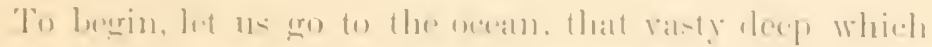
-

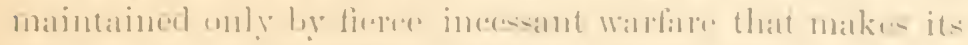

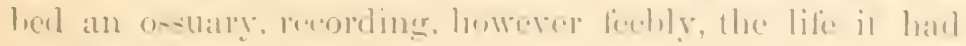
containel.

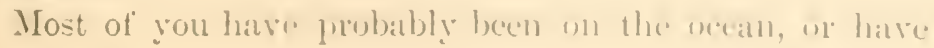


wandered along its shores; but I will first speak of an animal that all are familiar with in any erent.

TIIE OYSTER.

The oyster in this country forms one of the most common and most esteemed articles of diet, and if you wish to get an accurate idlea of the rast importance of the oyster industry. I would refer you to Mr. Emest Ingersoll's report recently issued from the Census Office. How many persons, while enjoying their oyster's-stewed, fried, broiled, scalloped, or from the shell-erer pause to consider anything but the flavor". How many dream that the lifeless and almost shapeless thing so grateful to their palate was at one time a free and active creature, swimming about in the ocean with considerable rapidity!

'The oyster is older than man. Evolutionists recognize that stability of life-conditions induces permanency of type, and as the conditions under which the oyster lives must have prevailed at a rery early period of the Earth's history we find that the fossil shells of its ancestors are scattered throughout the world whererer ancient oceans had their shores, while they particularly abound in the cretaceous formation. Prof. White, curator of Mollusea in this museum, has kindly loaned me some fossil forms which he finds abounding in the cretaccous of the West. They do not differ materially from others found in the Miocene, and you will see that in all of the hundreds of thousands of years that have passed since then, while, als Prof. Marsh has so well shown us, the present horse wits evolving through the various forms of Eohippus, Orohippus, Miohippus, etc., from a typically fire-toed ancestor, quite unlike its present self and common to it and other ungulate mammals; while other terrestial animals were undergoing like mutations, the oyster retained essentially the same form.

Howerer much they may differ in size, appearance and flavor, the present oysters of North America are all referable to one species, scientifically known as Ostrea virginiana Lister, 
while that of burope is specilicially different and known as Ostrece clulis $\mathrm{l}$.

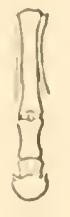

e.
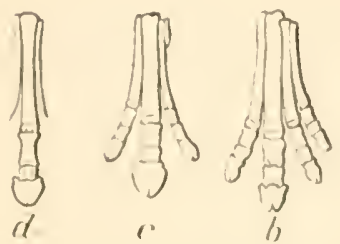

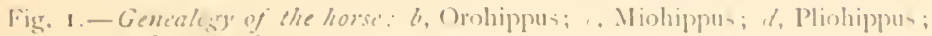
e. Equus. (After Marsh.)

The oyster has generally hem ronsidered hemaphrodite, i. A. combloning both sexes in one individual; and the young are said to be at first hatteherl and then protecterl insiles the mantle ravity of the parent. Though this may be true? of the European species, I)r. IT. K. Brooks, of Jolus Ilopkins: University, ly recent arminahle researches, hats clearly shem that our Amerian oyster has the sexes separated, amel that the young are hatcher in the free water, and have to take their chance without paresital are or protections.

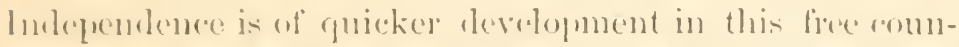
trye ase well in the orster are in man. Without geroing into anatomical details I would state that what we kurw ats the

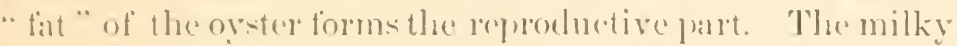

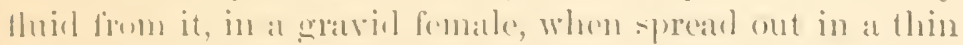
film will -how inmmonerable white watrian speres, even withwat the aid of at micereseope; whild that from a well-developed male is more homogeneons and more adhesire. This thuid is expellerl in the watere at the breenling season, and tho exge, mee adrift, must moet at male rell or perish. The average number of wa profucesl by a single fomalle is pere haps ten millions: and a larese sizel whe may produce as many as sixty millions. So you can imagrine at what an immense rate they womlat multiply alis they not, in the earer

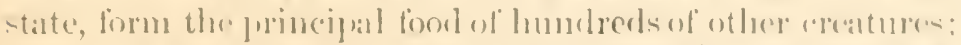
and had they not, in all stages of errowth, mumerons encmies.

Probably not more than one in -reral millions reatedes 
maturity. In mature it is a fumblumental principle that the individual should be sacriticed without limit to secure the good and perpetuity of the race, and the principle might be kept in mind to alrantage by those who discuss social problems that concern man.
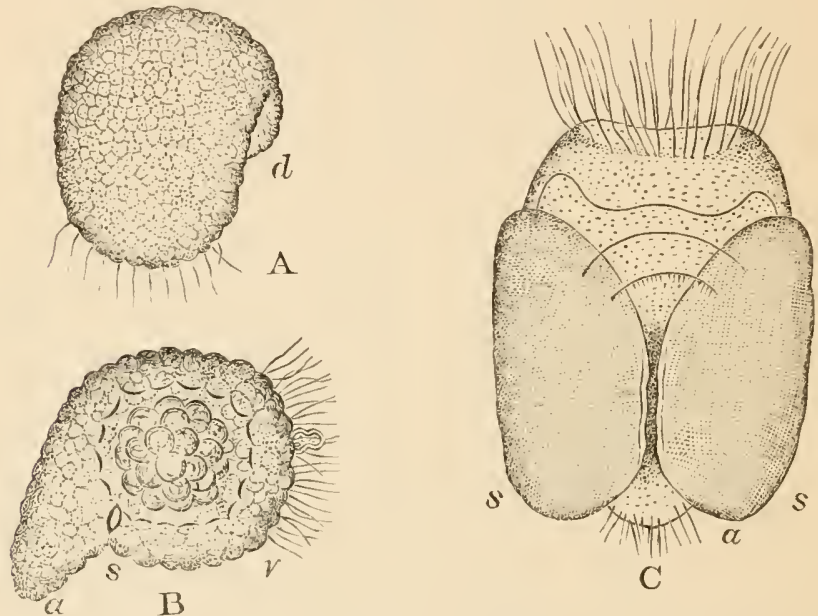

Fig. 2.- Youns of American Oyster: A, surface view of "spat" at first swimming stage. with external opening $(d)$ and cilia; $B$, do.. somewhat older, showing beginning of thell $(s)$; $C$, dorsal view of same still older, showing shell $(s)$ much increased in size-all highly magnified. (After Brooks.)

But to our youmg orster. Here you have its figure (2)-a soft, irregularly-shaped object, with numerous feclersor cilia, hy rotating which it swims about quite rapidly. These yomeg are called "spats" or" "spum" ly fishermen, and they" swim about till they cone in contact with some submarine body, on which they rettle, when they are known as "blisters." They will athere to any hand, clean olject, but not to mun or dirt. So sooner is the roung oyster fixed than it begins to alaborate its shell, which is composed chiefly of (anbonate of lime. The food of the oyster consists of valrious minute creatures, such as diatoms, rhizopods, and infusoria, which abound everywere in water or in mud at the bottom thereof.

You woulel hardly suppose that this lympluatic mass was endowed with extreme nerrous sensibility. Yet it will close 
its shell at the -lighte-t viluations and dies foum a - molelen

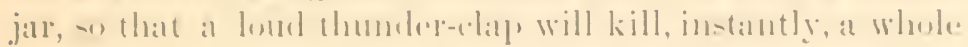
hoat baul. There is good erielence that orsters attain the age of thing vears, and 110 ond knows how monels longer they maly live.

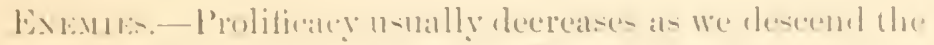

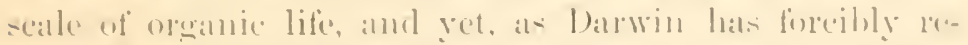

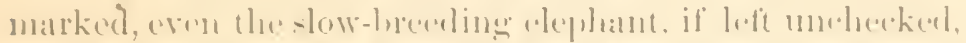

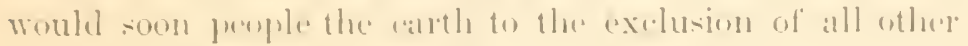

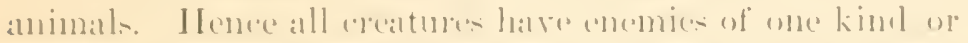

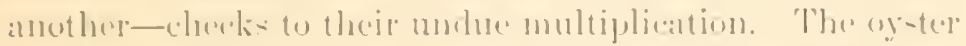

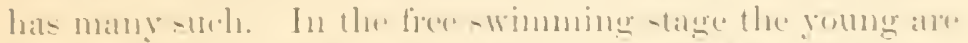

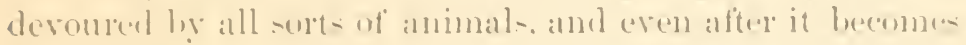
fixed it is freved mpon le many, while others ane truly palatsitic. horing or drilling hole- thromgh its shell.

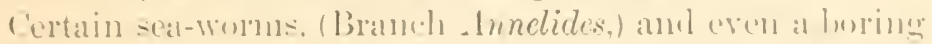
sjonge. (Cliona sulpherere Verrill,) help to perfirite the-luell. while -mall horing mivalve mollusk belunging to it- mon Brancle do the same thing. They alle known in emmmon

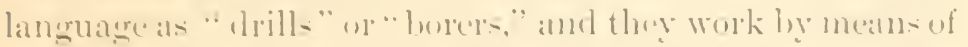

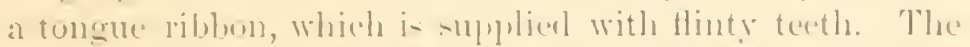

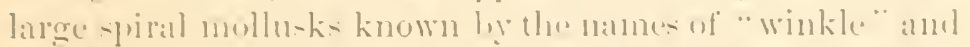
" comrh," of which l exhilit an example, prey upon the n-ter and eru-h it shell by -heer musenlar power of the

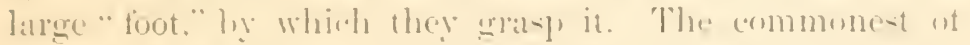

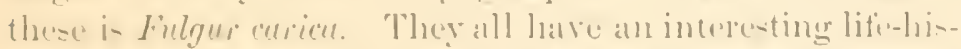

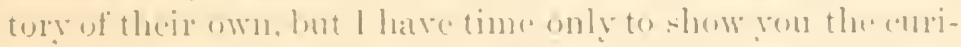

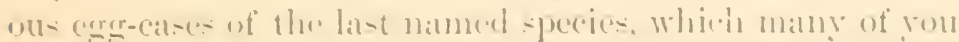

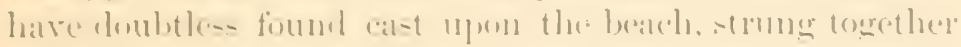

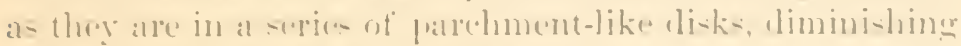
in size (1) wart either end ut the - tringe.

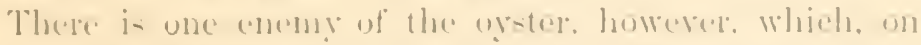

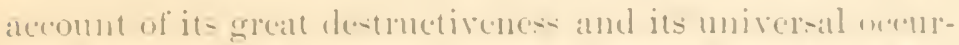

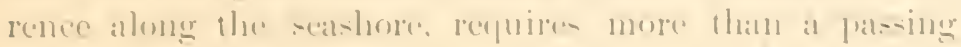
notive. I alluile to the-

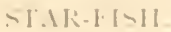

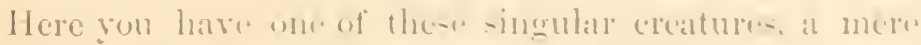
skelcton of it formei plump selt, when fillerl with water. 
but still showing the general character of the animal with its five fingers or ralys, each having, in a median groove beneath, a number of fleshy, disc-tipped tubes, or ambulacial, which perform the function of fect, and with its central mouth, a mere circular opening. The common star-fish of the Athantic coast (Asterias melgaris Stimpson, ${ }^{*}$ fig. 3 ) is the

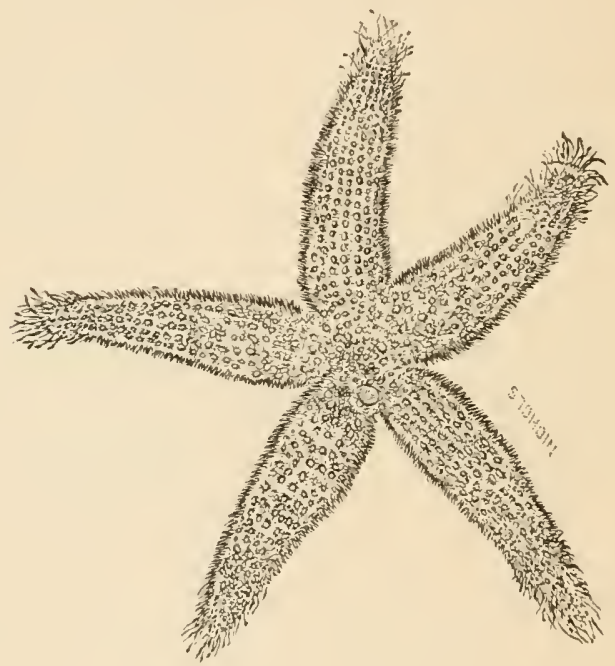

Fig. 3. Asterias zulsaris. (.After A. Agassiz.)

most destructive to the oyster, and may be taken as a type of the radiate animals. The sexes are separate, and the ova are fertilized in the water just as are those of the oyster. The analogy goes yet further, for the young starfish bears no resemblance to its parent, and swims about by means of rotating cilia. It first it is a mere spherieal mass, and then becomes bilateral. This first stage is known as the Bipinnaria stage, (Fig. 4, $A, B, C$, ) and as it grows ohler a series of arms develop until we have what is known as the Brachiolaria stage, (Fig. $4 D$,) a name given to it when its real character was unknown, a bit of zoological ignorance which, upon comparing these figures with the aliult, you will agree with me was quite excusable. Those who are curious to learn more 


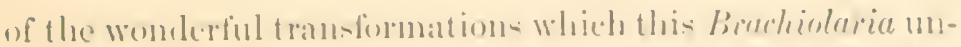
dergoes should consult the manguifient workes of . I lexander Agassiz on the subject. I hatre only time to state that the star-fish propere develope on the ab-opal enel of the latrat, which it tinally ahsorls, and that the achult star-fish, with its long arms. js not developerel for two or mole yearse the form meanmhile remanining embiral of dise-shaped.
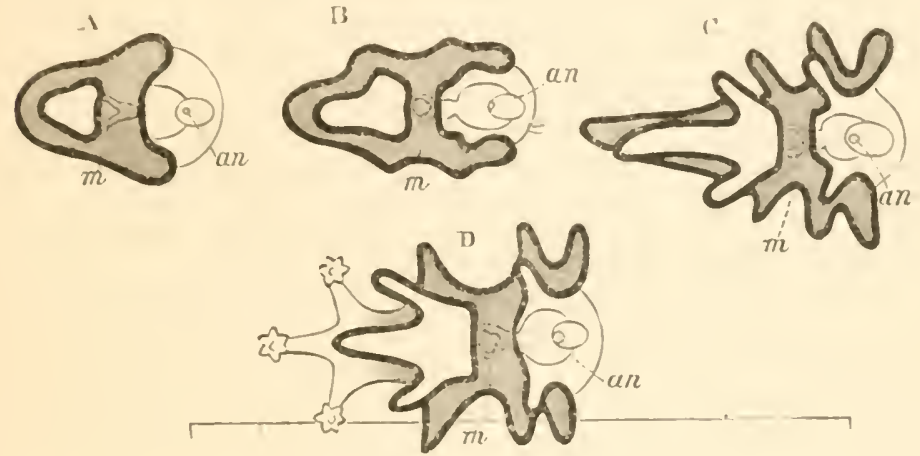

Fig. 4-Diagramatic view of young viar-lish: A, $A, C$. Bipinnaria stage in different acres; $D$, Irachiolaria sare. The blach lines repre-ent cilinted bands; the shading the space between the prix-ural and pout-oral band : $m$, the month; izll the anus. K.Ifter Miiller.

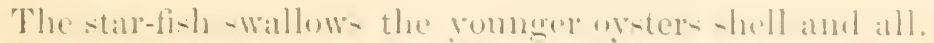

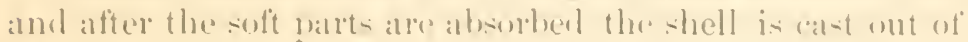

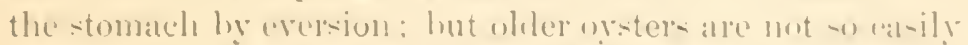

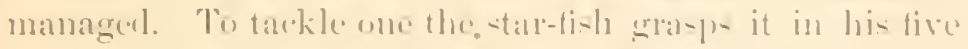
arms and then litte hy little hreake ofl the marerin of the shell hy the museles at the entranere of his stommath, ambl when a sufliejent opening has lwon effireterl the di-ten-ilo month is intrubled mutil the soft orstor is soimenl and inu-limedr.

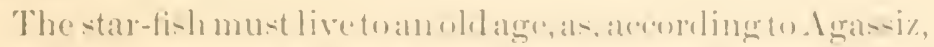

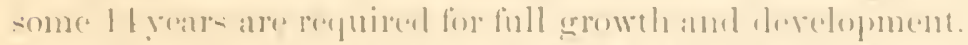

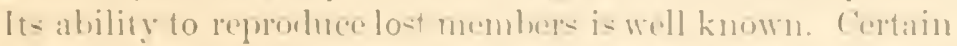

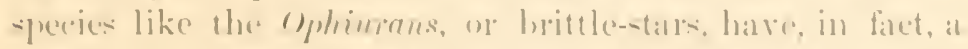

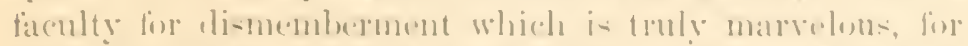
they brak theje limbs to pioces when irritaterl. The rays, when broken, are renewerl, but the stomach, if -everenl. of 
divided, cammot be renewed. The idea, therefore, that oyster fishermen, in cutting up the star-fish, "make two or three star-fishes out of each captive," is evidently erroneous. This insensibility to mutilation is common to a large number of the lower animals found on the coast. The sea-anemones (Actinozoa) accomplish eren that mathematical paradox, multiplication by dirision; for when they move from one part of a rock to another, they often leave fragments of thenselves behind, and these fragments soon become smooth and spherical, and are transformed to perfect, though minute, anemones. The flat-worms (Eurylepta) offer a still more remarkable instance. When cut to pieces, each piece not only continues moving in the direction in which the whole animal was moving at the time, but gradually becomes complete in all its parts-a veritable "chip of the old block." It is related that two polyps often attempt to swallow the same prey, and when this is not easily serered the largest polyp gapes and swallows his antagonist. This last seems, however, to be the gainer by the operation, as, after lying in the conqueror's body for an hour or' so it issues unhurt and often in possession of the original bone of contention.

THE CRAT.

Next to the oyster few animals are more often on the tables of the Washingtonian than the crab, and I will ask you to bear his form in mind-whether as rou have seen him seampering along sidewise on the sand or dished up "deriled," or in "soft shell;" while I rapidly trace his development. The erab undergoes such changes that it has been known by different names at different periods of its growth, and has been placed in distinct orders. The species most used here and southward is known as Callinectes hastatus, but as its early history has not yet, so far as I am aware, been critically studied, I will take the common shore crab (Cancer irroratus) as an example, for it is closely allied to the European table crab. Here we have a picture of the newlyhatched or Zö̈a form. (Fig. 5.) You will agree with me that in this singular, long-bodied, long-spined affair there 


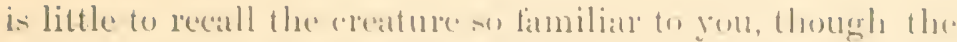
structure is fiat better adapted to swinming freety in the

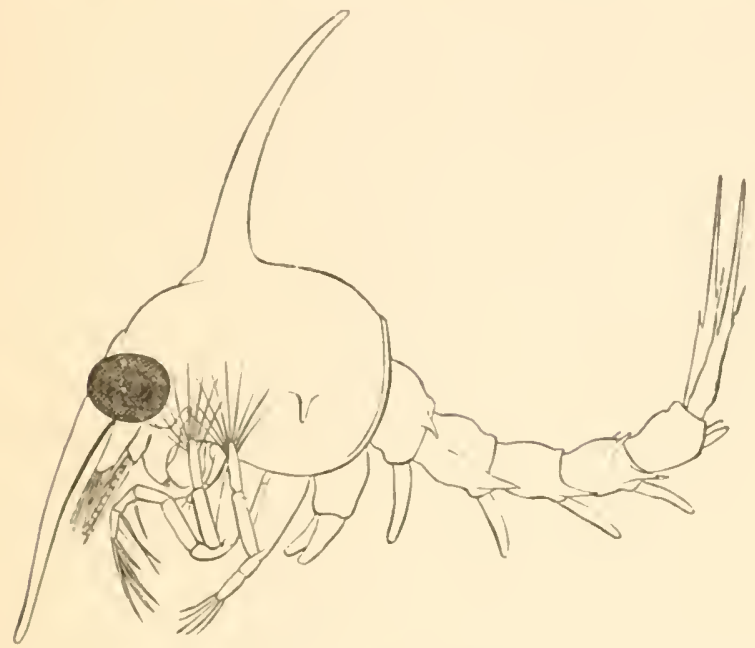

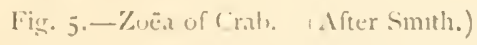

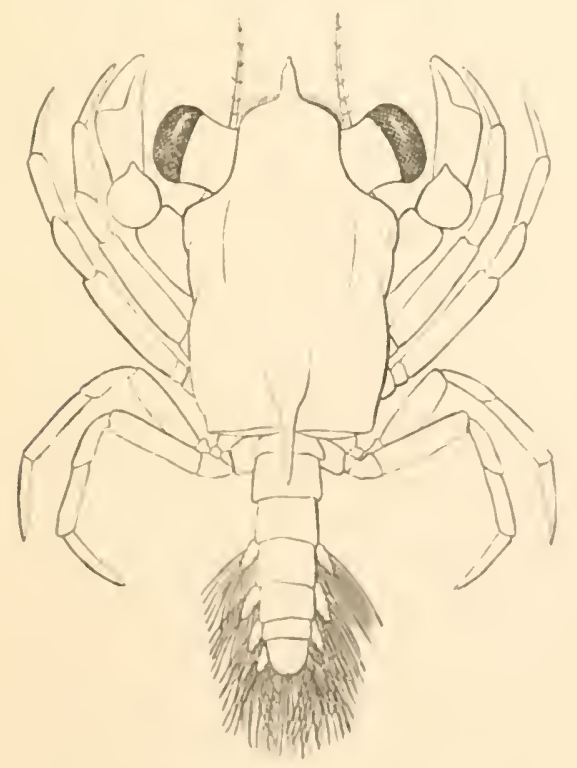

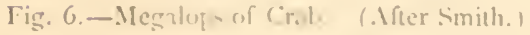


water. In some crabs belonging to the genus Porcellana the anterior spine or rostrum is supple, and many times longer than the body. After a few months the form changes materially, the mouth-parts, which before were swimming legs, are now fitted for preparing the food, and we have what is known as the Megalops condition, which looks much like a lobster, but in which the mature crab is sufficiently foreshadowed. (Fig. 6.)

Let us now leave the ocean and talk of a few of the commoner animals inland.

THE FROG.

The common frog, (Rana temporaria, which oceurs both here and in Europe, passes the winter buried in the mud of stagnant waters, in a torpid condition; aye, and it may even be frozen till it is so brittle as to chink, without the loss of life. The frogs are now issuing forth to join with their peeuliar eroak in the zoölogical concert of spring. The accompanying figures will aid us in understanding the transformations of the frog. They are poor copies of the ardmirable originals of Roesel von Rosenhof, generally credited to Mivart, because this last anthor failed to credit them to the proper source. Hatching from dark globular eggs enclosed in a transparent, gelatinous fluid which agglutinates them. and enables them to float in masses on the water, the young tadpole congregates under the leaf of some aquatic plant, where it feeds by suction. It has prominent external branchire, and is in every respect admirably adapted to aquatic life. The legs are first seen as mere buds, the front pair hidden under the opercular membrane. As they develop the gills are absorbed; the mouth loses its suctorial character; the eyes, instead of being concealed, become exposed, and the front limbs are uncovered. The tail is next gradually absorbed, and the animal is now truly amphibious, for the lungs, which have replaced the gills, enables it to live out of water. From a vegetarian it has become carnivorous and now comes on land in search of worms and 
in-ects, and in stleh numbers in damp weatlere as to give

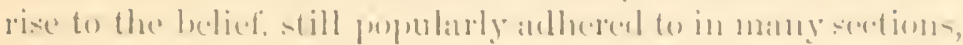
that it hats latimed foress.

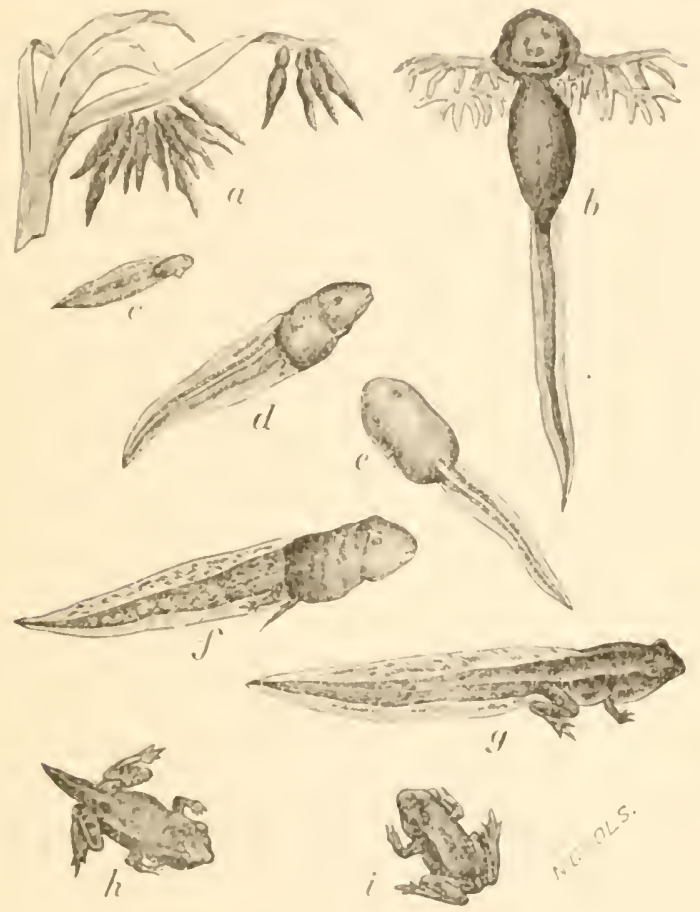

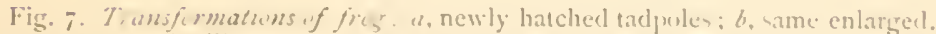
howing eternal gills: $c, d, c$, later stagen, the gills enclened ly the opercul..r membrane; f, stage with hind limb developing; $\therefore$ after molt with both pair wf lamb showing: $h$, partial atrophy of tail : $i$, full formed young frog. After kü-cl. )

They plumge into the mud atgatin att the alphouch of

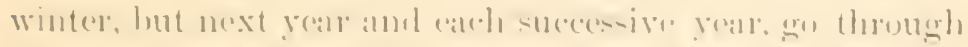
a performance of which mally of gom ane net probalily.

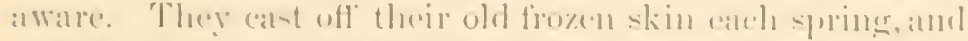

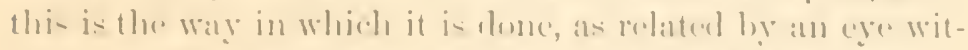
me. Let us imagine we are on the alge of some swamp and alre watching some large fellow who is about (1) undre.him-elt. Like the rest of his hedhen he has had such at shamefully long sleep, that on atwakening he fick dull and 
stiff, and does not like to appear in society till he has thrown off his old worn-out garments and put on new ones, never hesitating about the fashion, but following the pattern of his ancestors for generation upon generation. He begins by presing his ellows hard against his sides, and rubbing downwards; he keeps on until the skin on his back bursts, and he then works it into folds on his sides and hips. Now, grasping one hind leg with both his hands, he hauls off one leg of his pants, and there! almost before you can count three, the other goes in the same way. He now takes the cast-off cuticle before him, between his legs, into his mouth and swallows it, and even while it ret descends the gullet, he has torn off the sin underneath, and brought it to his fore legs or hands. and grasping one of these with the other, by considerable pulling he strips them. just as we should strip off a shirt, and by a single motion of the head he draw the skin from the neck and swallows the whole with a c-r-r-r-oak of satisfaction, for he knows full well, that such a dainty morsel he can get lut once a year.

Most frogs and toads go through the tadpole development in the water. but in some terrestrial species where marshes are scarce or lacking; the development takes place either before birth or in a marsupium or sae on the bark of the parent. The tadpole state may also be indefinitely pro-

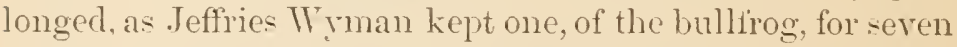
years, or many more than the natural period of larral existence. The frog is a true rertebrate, belonging to the same great Branch of the animal kingdom as man. Yet the changes it undergoes after birth are as remarkable as are those we have alrearly noticed in the lower Branches. In some allied animals, indeed, development is permanently arrested in the tadpole state, and I will, before passing to a few well-known insects, briefly refer you to a rather remarkable animal which occurs in our brackish Western lakes of high altitudes. I refer to it in order to show how greatly form is influenced by conditions. Here we have figures of it. (Fig. S.) It was described by Prof. Baird as Siredon lichonoides, and. as you will note, has many of the character- 
inties of the tadpole of the frog, its external branchise and membranous back and tail, well fitting it for aquatie life. Now this siredon will cither retain this larval form permat-
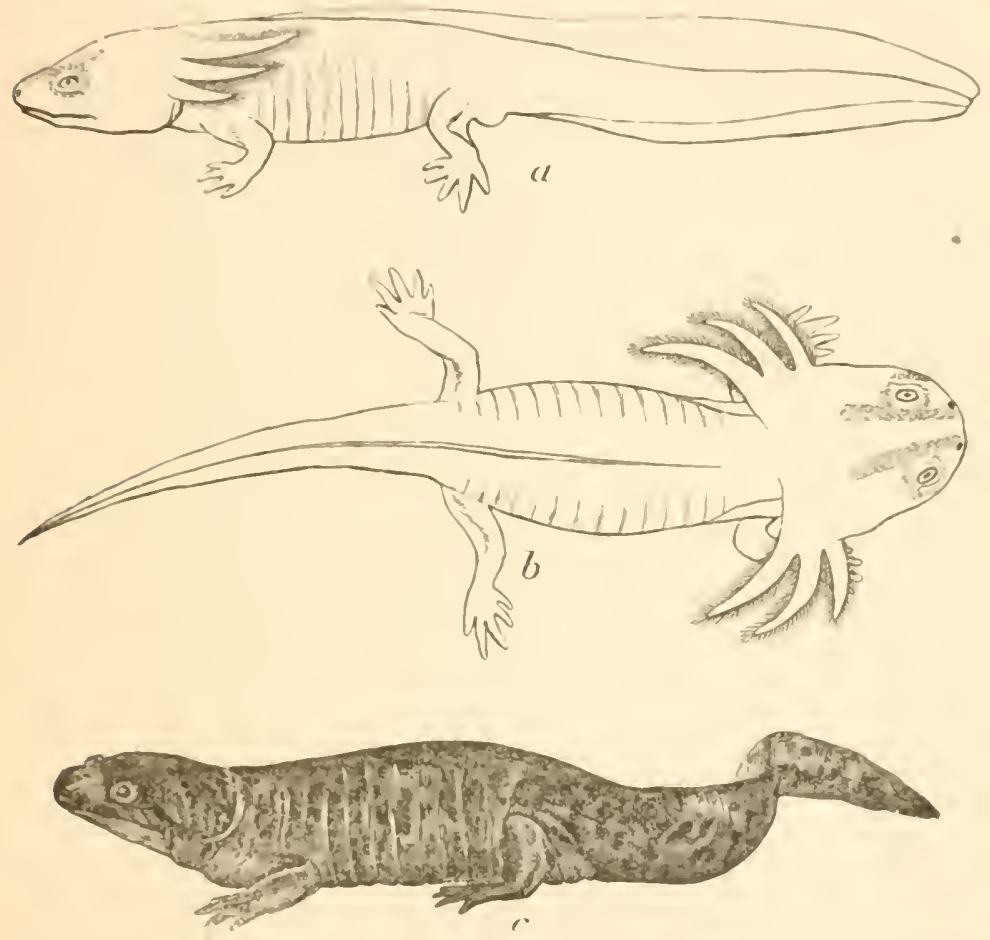

Fig. S. Amblrstma mazentim Baird: a, larval form or Siredon lichencide Baird, side view; 4 , do., dor-al view ; , mature form partially developed and cor-

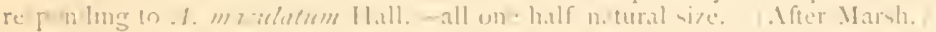

nently and perpetuate itself, or elso may berome transformat

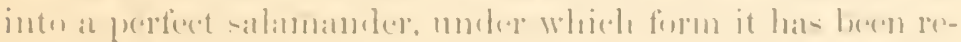

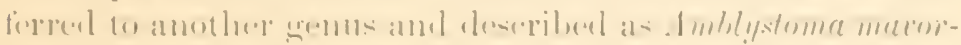

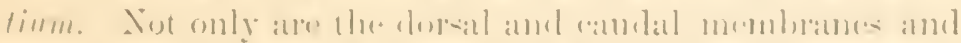

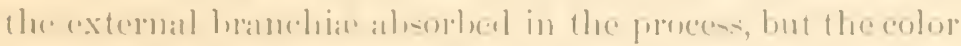

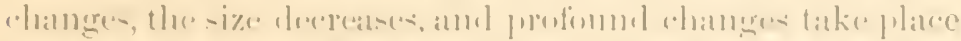

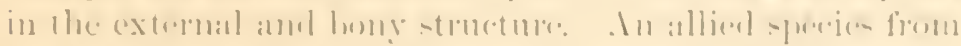

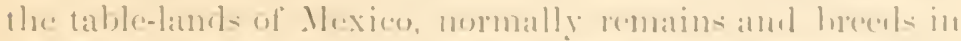

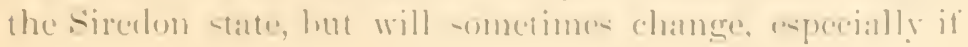


brought under changed influences. The siredon form of this last is known by the rather unpronounceable name of Axolotl, or $A$ wahgolotel as the Mexicans speak it, and the mature form is Amblystoma mexicanum.

It greatly resembles the species first mentioned, and since this has been referred by different anthors to three or four diflorent genera and varies so as to have had at least half a dozen specific names given to it, we may pretty safely assume that the Mexican form is also but a well-marked variety. Most reptiles, and especially batrachians, vary much in color, and have the power in greater or less degree of simulating that of their surroundings. The common treetoad is a familiar example: so that the discussion about species may sometimes be likened to the quarrel of the knights who were looking on diflerent sides of the same shicld. Before leaving the Sireton I desire to say, in justice to the able and belover director of this Museum, that already in 1849 , or long before their specific connection had been establisherl by experiment, he correctly inferred that Siredon would prove to be the larva of Amblystonia.

\section{THE IIOUSE-FLY.}

The most persistent companion of man is, perhaps, the house-fly. It has followed him everywhere in his own conveyances, and is found, so far an we know, wherever civilized man has establisher himself. Our American house-fly was described as a distinct species (Musca harpyia) by Harris, but Packard found it, after critical comparisons, specifically identical with the Linnaean species. Already, with the growing warmth of this beautiful spring month, the fly begins to show its familiar form in our houses, and to inspire the careful housekeeper with feelings any thing but agreeable. Whence comes it? How has it passed the winter? Such questions are often asked. Let us answer them. Not all who have watched the fly poising or darting noiselessly and gracefully in mid-air, or deftly making its toilet, have realized that at one time it was a crawling maggot, as unlike its perfect self as two things well ean be. 'The eggs are about 
fomr-humbredths of an inch lomer onc-fourth as wide, dull white in color, and pitted with dongate. hexagonal depression-mere whitish spees to the mainled eye, laid in little

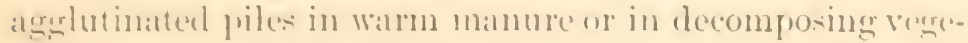
tation, equedally that about our stables and harn-yanks. From st to 100 are latil at a times, and probably at three or four ditlerent intervals by the same fly though on this point we have nu siald data. Within 2.1 homs, in smmmer, they liatch into footles malerots, which, atter rioting in filth till their tende! skin- seem realy to burst from repletion he-

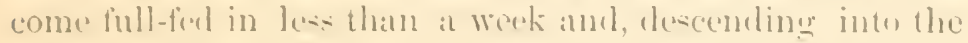
carth or sheltering moler some old board. contrated to hrown, shining objects, rombled at both ends. and technically known as puparia. Within the darkness of this hardened

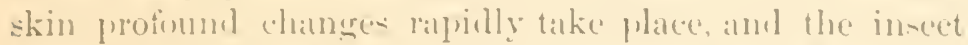
palsese- through the pupal to the pertect state. and finally, in about fire days. the anterior end of the puparim is pushed oft and the fly quickly crawls out. It first it-part- atre pale and soft. and its wings are ermmpled and liseleses, but

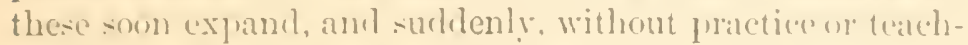

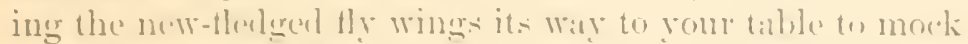
your displessure-to - hare your repast. The lenerth of time required from hatehing to maturity raries with the sea-on

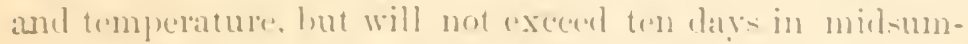
mer, while the life wi the perfecet fly lasts abut the weeks

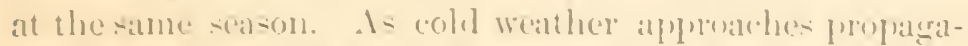

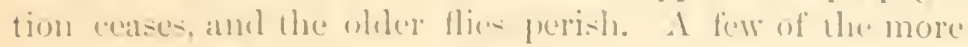

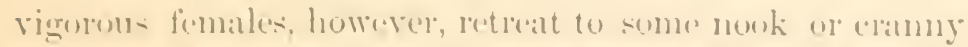
where. in a state of torpor. they strvive till the anstainger

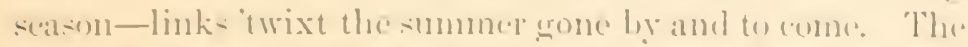

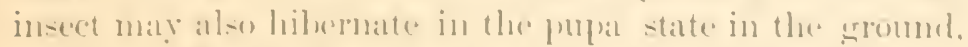
a- I have fomml the pruparia quite late in the fall. In rooms kept continumsly wam, or in more senthern latitucles. the fly rematins aretive all winter, atnel our palace slecpingeatrs bring them daily to us from Florida during the eoldent monthe of the yeart.

I have no figures of the homse-fly in its diflerent states 
with me, but they bear a general resemblance to those of the flesh-fly. (Fig. 9.)

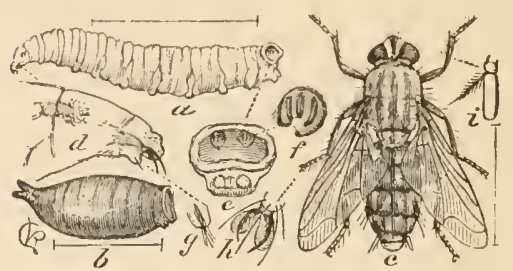

Fig. 9.- Sarcophaga sarracenia: a, larva, b, pupa, $c$, fly, the hair lines show, ing average natural lengths; $d$, enlarged head and first joint of larva, showing curved hooks, lower lip $(g)$, and prothoracic spiracles; $e$, end of body of sameshowing stigmata $(f)$ and pro-legs and vent; $h$, tarsal claws of fly with protecting pads; $i$, antenna of same-enlarged. (After Riley.)

You will notice that the larva tapers toward the head, which is retractile, and armed with two black hooks. It is blunt and truncate behind, and breathes principally through a pair of spiracles situated on this truncate, anal end.

While I must pass over the complicated mouth, the stereoscopic: eyes, with their 4,000 facets, and many curious details in the structure of the fly, it will be well to dissipate two quite widespread popular errors in regard to it. Most of the old authors tell us that the fly walks on the ceiling, and in other ways defies the laws of gravitation, by suction. You will notice from the figure of the foot of the flesh-fly (and that of the house-fly has a similar construction) that it ends in a pair of strong hooks and a pair of pads or cushions, technically termed pulvilli. These were supposed to act as sucking disks by creating a vacuum, on the same principle as does the piece of eircular leather used by school-boys for a similar purpose. In reality, howerer, these pads are beset with innumerable knobbed hairs, which are kept moist by an exuding fluid. In short, we have here a repetition, after a fashion, of the ambulacral suckers of the star-fish. The smoother the surface, the greater the adhesion of the digituli. This you will at once understand by gently pressing or drawing the moist finger ends over a glass window, or other polished surface. The adhesion is very sensible, whereas, 


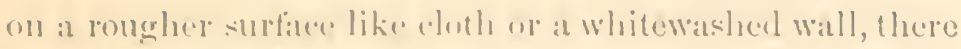

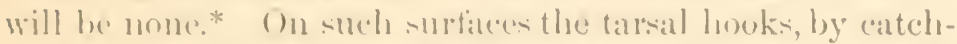
ing in the numutest irrenglarity, take the plate of the parls in as-isting the fly's lexmmotion.

The other prevalent fallacy is that the smaller flies often noticerl in our louses ale young Hixs. In the fly, as in all wher insects, real errowth takes place only in the lanval state. It enck with the issuing from the pupa and the expantion wf the wings. Individuals difler in size at maturity just as they, to in man and other animals and various other speries of Dipterat are often associated with the house-fly, but they are all finll-grom?

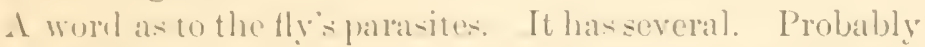
the mo-t (o)mmon is the microseopic plant or funerus: Empusa mesea, which su ofton sleds a misty halo aromed it in autumn. amel fastems it sermely to the window pane; lut the title to these remarks exclucles its consideration in detail. I true internal parasite has been fomm in the pruparium by I)r. Packard, the eharacter of which puzzled him, lut which is jubably a rove-bectle (family stapleylinidar.) and probably of the grous Olcochare, a species of which is known to be parasitie un an allien genus (inthoneyia) of flic. The paranite most noticel, however, is the little red mite which so often attalues to it near the hase of the wings. Here you have it when fir-t latelicel, frig. 10, and in the

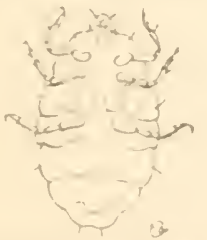

Fig. 10.- Larsa of Iirombidum mu curum. (After kiley.)

six-legged or Astome form, having been referred to that renus before its latral character was mulerstooul. Ifter attaching to the Hy it - boly wwells and it s legs get relatively

* Prof. E. D. Cope mention that on this principle, eten the Imblyutoma we have ju-t talked about climb a plate of glans with great eane ! y arlherinz clourly. to its surface with the moint alslomen. 
smaller until we have a mere bag, which finally falls to the ground, and there lies helpless for a few weeks, during which the mature form which I have described as Trombidium muscarum, and which has eight instead of six legs, develops under the Astoma skin. The spherical red eggs are laid in loose masses in the ground, and the young Astoma, upon hatching, crawls upon the first fly which offers it an opportunity.

T'o show the transformations I exhibit illustrations (Fig.

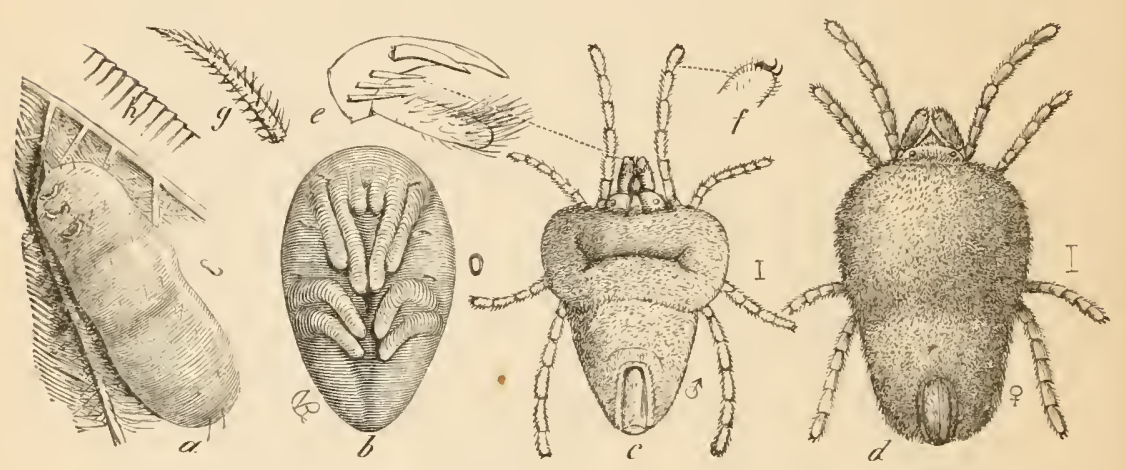

Fig. I1.-Trombidium locustarum. - $a$, mature larva when about to leave the wing of a locust; $b$, pupa; $c$, male adult when just from the pupa; $d$, femalethe natural sizes indicated to the right; $e$, palpal claw and thumb; $f$, pedal claws; $g$, one of the barbed hairs; $h$, the striations on the larval skin. (After Riley.)

11) of an allied species (Trombidium locustarum Riley,) which similarly affects locusts or "grasshoppers," and I would parenthetically remark that man is as much subject to annoyance from these red mites as are the fly and locust; for the irritating pustules so common in late summer and autumn on the limbs of persons who walk in rank grass or along rivers are caused by a minute red mite, (Leptus irritans Riley,) popularly denominated "Jigger," and evidently the six-legged larva of some eight-legged form not yet ascertained.

\section{PARASITISM.}

This external parasitism in insects is, however, less remarkable than that which is internal.

If I should tell you that I know certain kinds of birds 
which bore holes inte the bodies of cows, sheep, aur other herbivorous animals, and therein deposit enges; that there eggs hatch inte lizands; that these lizards grow fat at the expense of the sheep, but without immerliately killing lhem; that, in fatet, a sheep so atfereted eomld live without eating for years, where otherwise it would die in a few days without food ; that the lizards in lime leare the borly of the sheep in numbers and lumow inte the ground ; and that, finally, after the lapes of an indetinite periorl, they istue forth in the form of birds like their parents, why, not one of you would believe me! But, it is only by drawing some such striking picture that I wan hepe to enney to you any colrect irlea of the rematrable ficts of parasitisn in the insect world. Ylost insects halve primary parasites, but in some (alses the alre themeches preved on by secondary parasites and these again hy tertiary ones; so that a worm may be at preipatetic banqueting hall for several other insects at the same time.

To be more explicit and exact, let us take a familial example. The typieal female Ichneumon-fly has something

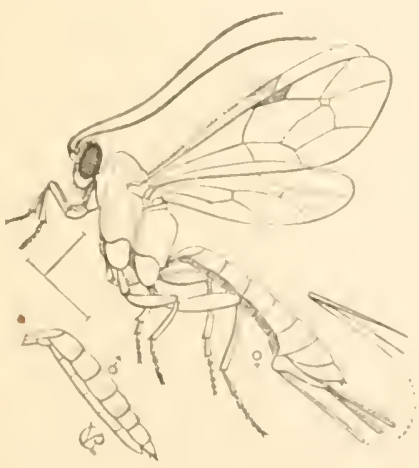

Fis. 12.-Pimpla annulifs: Gutline vile view of female and of male abdo. men. Xfter Riley. )

of this lorm which I will draw on the blackboard, (-ee Fig. 12, Pimple ammlipes br.,) its chief chatacteristics being the long ovipusiter with the two sheathe, puseseet by the female but not lo the malle. 
Let us take for examples the large Potato-worm or any other Sphinx larva with the horn near its end (which seems to lave no other purpose that to frighten superstitious people who erroneonsly believe it to be capable of inflieting a poisonous sting,) and one of its commoner Ichneumon parasites belonging to the gen us Microgaster. Our female Ichnenmon-fly hovers about the worm while it quietly feeds. Settling finally on its back, generally behind the head where its mouth cannot reach her, she deliberately thrusts her oripositor through the skin of her victim and oviposits within its body. Ifer young are soft, whitish larve which, upon issuing, spin upon the poor worm's back a number of eggshaped cocoons (Figure 13,) often mistaken for eggs by the

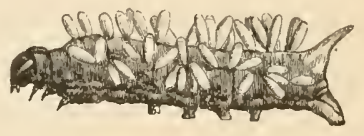

Fig. 13.-Shrunken larva of Chorocampa pampinatrix, with Microgaster cocoons. (After IIarris.)

uninitiated. Within these the transformations are undergone, and the perfect flies cut a lid throngh the top of the cocoon and escape, sometimes while yet their victim shows faint signs of life. Now such a parasitized worm will drag out a paralyzed kind of existence without food for several weeks, where, normally, it would starre to death in as many days, and the parasite may, in its turn, be infested with a secondary species, ete., as above stated.

\section{THE MOSQUITO.}

There is another little lady whom you have fed and regaled at your own expense, and very unwillingly withal. She is by no means modest, but steals unbidden into your room. She generally heralds her coming with song that is anything but soothing, and she is so persevering that even the strong "bars" with which you protect yourself are not proof against her persecutions. Iou have all, no doubt, at times exercised a little strategy with the mosquito, and 
when the little torment wat fairly settled, matle a dexterous morement of the hamd, and with a sap exelaimes, "lie got him this time!" Do such thing; rou never got him in your life, but probably have often sucereded in erusthing her, for the male mosquito is a conviderate sentleman. In lieu of the piereer of the female he is lecorited with a beautiful plume, and has such a lore of home that he seldom sallies forth from the swamp where he was born, but contents himself with vegetal lather than animal juices. (I do not wish to make any reflections, hut in the insect world it is always the females which sting!)

But to its history. The mosquito was not born a winged fly, and if you will examine a tub of rainwater that has stood uncovered and unmolested for a week or more luring any of the summer months, you may see it in all its various forms. You may see the female supporting herself on the water with her four front lews and erossing the hinder pair like the letter $X$. In this support made by the legs: she is depositing her eggs. which are just pereeptilile to the naked eye. By the aid of a lens they are seen to be slued together so as to form a little boat, which knorks abuut on the water till the young hatch. And what hatches from them? Why those very wrigglers (Fig. 14,f) which jerk away erery

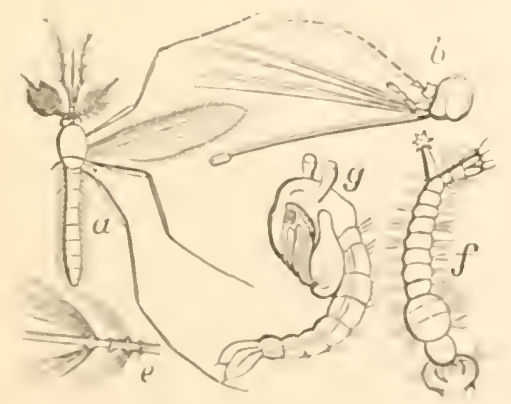

Fig. 14--Culer fifion a, male: b, beal of female; e, joint of male antenna ; f. larsia: 5. pupa-all enlarged. After 11 e'twnot?.

time you touch the water. They are destincel to live a certain period in thi- watery element, and cannet take 
wing and join their parent in her war song and house invasions, till, after throwing off the skin a few times, they have become full-grown, and then with another molt have changer to what are technically known as pupe (g.) In this state they are no longer able to do anything but patiently float with their humped backs at the surface of the water, w to swim by jerks of the tail beneath, after the fashion of a shrimp or a lobster. At the end of about three days they stretch out on the surface like a boat, the mosquito bursts the skin and gradually works out of the shell which supports here during the critical operation. She rests with her long legs on the surface for a few moments, till the wings hare expanded and become dry, and then flies away to fulfill her mission, a totally different animal to what she was a few hours before, and no more able to live in the water as she did then, than are any of us! Is it not wonderful that such profound changes should take place in so short a time? Even the bird has to learn to use its wings by practice and slow degrees, but the mosquito uses her newly acquired organs of flight to perfection from the start!

In this transformation from an aquatic to an aërial life, the mosquito has first breathed from a long tube near the tail; next through two tubular horns near the head, and, finally, through a series of spiracles along the whole body.

From a calculation, made by Baron Latour, the mosquito in flight ribrates its wings 3,000 times in a minute-a rapidity of motion hardly conceivable.

Those who have traveled in summer on the lower Mississippi or in the Northwest have experieneed the torment which these frail flies can inflict: at times they drive everyone from the boat, and trains can sometimes only be run with comfort on the Northern Pacific by keeping a smudge in the baggage car and the doors of all the coaches open to the fumes.

The bravest man on the fleetest horse dares not cross some of the more rank and dank prairies of Northern Minnesota in Jume. It is well known that Father De Smit once 


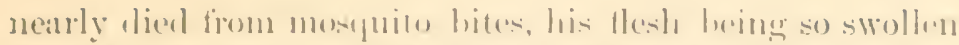
aromed the allus and legrs that it literally burst.

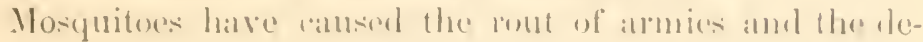

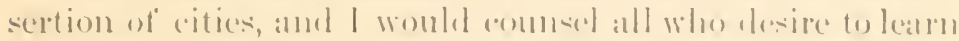

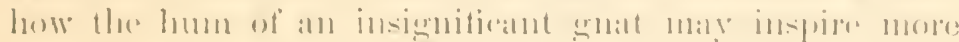

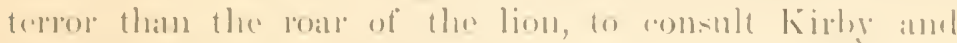
-

There are many -yerex of the mospuite, all diflering

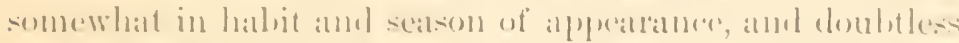

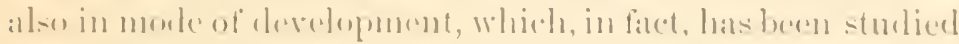

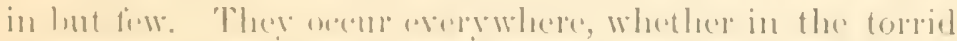

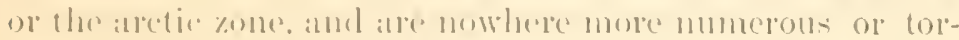
menting than in lanblame.

both the fly and the mosquito atre srout soavengers in intiney, the one puriling the air wo breathe the other tho water we link. They perform, in this was, an indirect

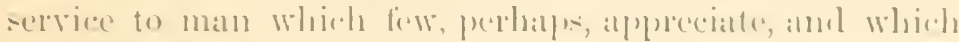
-monembat atones for theil hall hal hits in maturits.

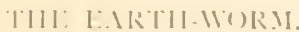

'The mext well-known animal that I shall speak of is the

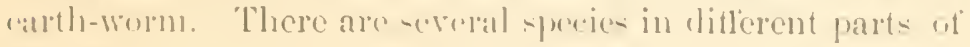
the worlel and I am not awalle that any one has (ritioally

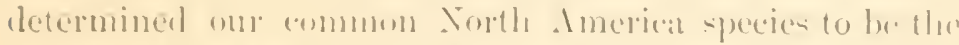

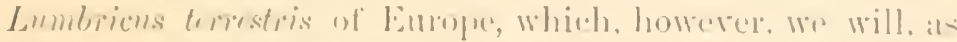

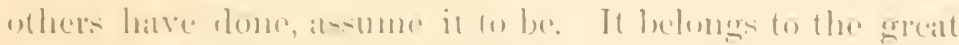

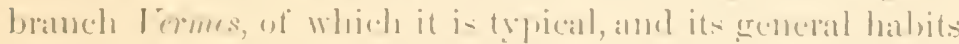

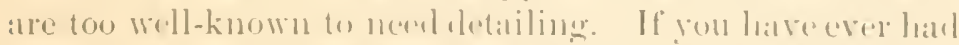
oceasion to eatch worms line some pet himl or for baiting jur-

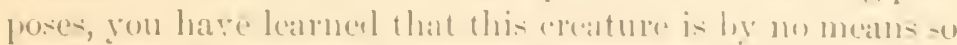

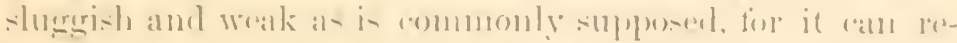

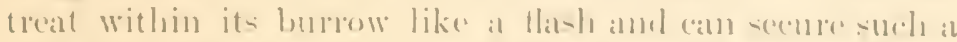
firm holel therein as to almo- ledie rextration intart. Flatee one upon your lamel aml it = morveluents will (am-e a slight

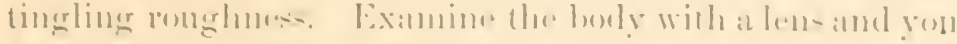

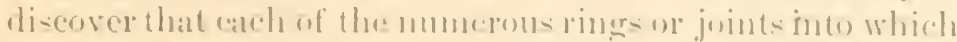

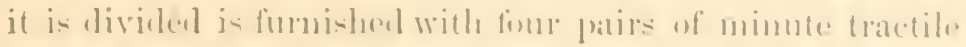

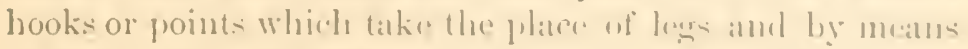

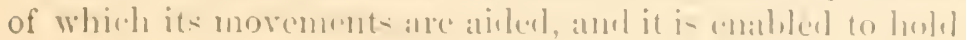


to its burrow as above indicated. The earth-worm is hermaphrodite. Yet the junction of two individuals is necessary to liberate and fructify the ova. At certain seasons a few of the rings, generally near the anterior third of the body, swell so as to look much like a healing wound. Two individuals join at these swollen parts, a glutinous secretion aiding the conjugation.
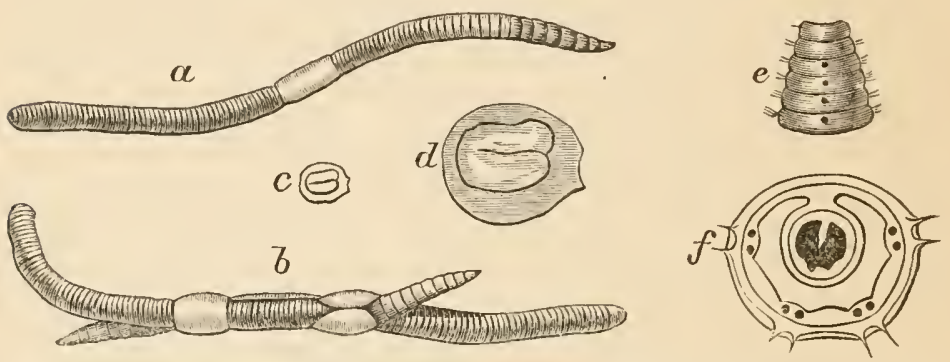

Fig. 15.-Lumbricus terrestris: $a$, worm with pale, swollen rings; $b$, two conjoined; $c$, egg, natural size; $d$, do., enlarged, (after Curtis;) $e$, a few rings; $f$, transverse section, showing spines, enlarged. (After Samuelson.)

The young worm is born much like its parent, either free or in a cyst-like covering, which subsequently bursts-the nature of the soil having apparently something to do with the elifference. In some species a number of eggs are enclosed in a single capsule. The worm, though living in the earth, is really semi-aquatic. It will live a long while in water, but soon dies when exposed to the dry air. It delights most in damp soil, and takes advantage of rains to travel at night on the surface, and in early spring it is often allured in great numbers on to the warm pavements of our city, where many perish if the weather becomes suddenly cold or the pavement dries out too rapidly. The earth-rorm hibernates at the bottom of its burrow, which may extend from three to six feet in a light soil; it also remains coiled up in a state of torpor during very dry weather. It is by no means devoid of sense or intelligence; but it is as an agrent in indirectly promoting man's welfare that this humble creature performs a part that few suspect. The same genius who so profoundly influenced modern scientific thought by the 


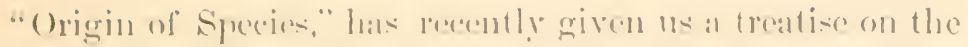

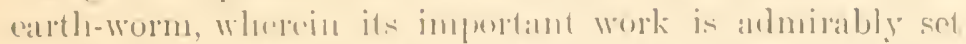
forth. Worms are in reality the original tillers of the soil,

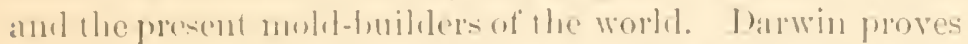
the entertues of the position he matintained somo forty-five

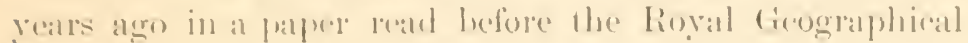
Society of lomdon. vi\%: that "the farmer is only imitating in a chms manner, without being able to biog the pebbles or sift the fine from the coalrse soil, the work which nature is daily performing hy the ageney of the eathth-wom." ly y.

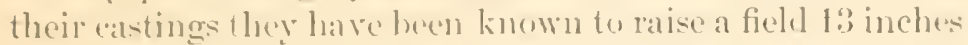
in sी years, and they have not only helped materially in

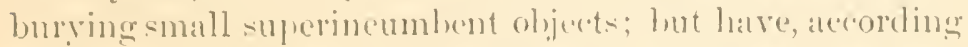
to J)arwin. played an inmertant part in the burial of anseicnt

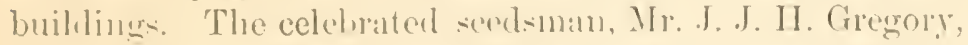
of Marblehearl. Mass.. (arefully roblected the castings laily"

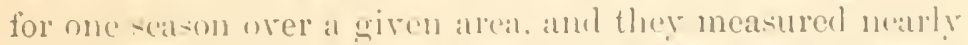
a quatet to the squale font. or mongh to ratise the surfiare of the land latt an inch. Ho also, by experiment, shows that

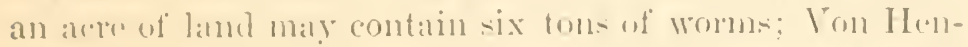
sen estimated .:3,7ti, worms to thr acese and that they would

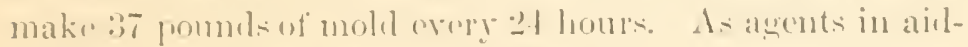
ing alenulation they are alio porrertul.

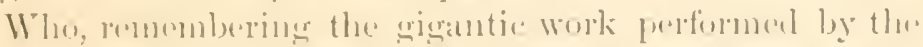

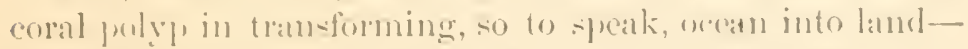
the important part it has played in the contiguration of con-

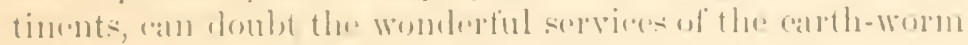

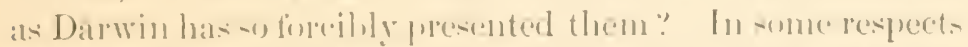

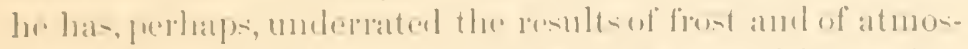

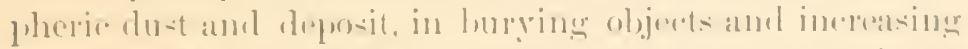

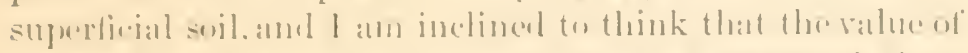

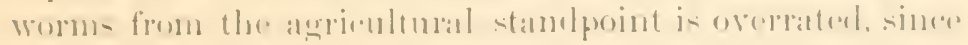

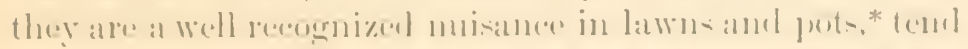

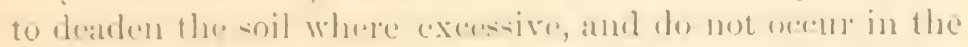

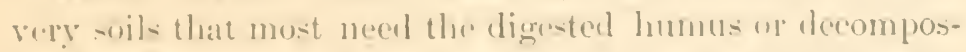
inger vegretation which they cast 11 ): but allowing this, the

* Ciraled horse-chestut or lime mixed ur the sul will w lueve the same of worms 
worms' part in the history of the world, and in a geological sense, is still amazing.

There are, indeed, very good reasons for believing that all genuine loam is produced solely by worms.

"Think naught a trifle, though it small appear;

Small sands the mountain, moments make the year, And triftes life!"

And now, ladies and gentlemen, the limit of time which custom and a due regard for your feelings have established for these lectures has been reached. I had hoped to say something of the scale-insects which are so common and destructive on onr fruit trees and other plants, and which give us the lac and the cochineal of commerce as they gave the mamna to the people of Israel ; to show you how perfect a parallelism may be traced in the history of some of them and that of the oyster:--the active young; the degradational development; the formation of the shell; the way it is perforated by parasites, etc, offer a remarkable instance of the existence of that misleading analogy of function which Prof. Gill so ably dealt with, in creatures which belong to different branches of the animal kingdom, and which possess no possible homologies with each other. I had hoped to give you some details of the remarkable hyper-metamorphoses and life-luabits of the blister-beetle, of which we annually import large quantities under the name of eantharides, when we have a number of indigenous: species with as good or better vesicatory properties. But, above all, I wanted to treat of the butterfly, for if the transformations of the animals I have already spoken of are remarkable, those of the butterfly from the caterpillar, through the chrysalis, transcend them all, and have always excited the greatest curiosity and wonder; while the feat which the caterpillar in some instances performs in the change to the suspending chrysalis is really marvelous, and was first properly explained, a little more than two years ago, before the Philosophical Society of this city. I have been able only in the most imperfect manner to treat of the more salient facts in the lives of some half dozen of the numerous ani- 
mals fombliar to all, and if I halve surecenled in investing these with a new interest in your eyes, the eflort will mot

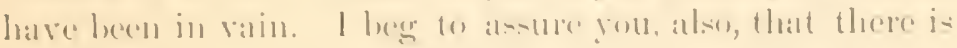

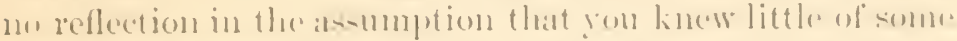

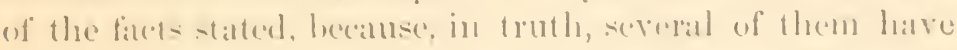

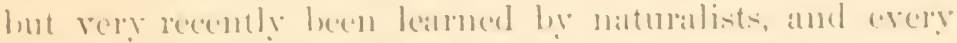

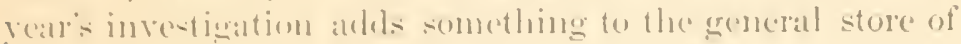

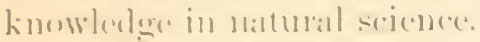

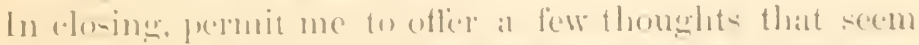
naturally to flow frem the matter of this lecture. Me have

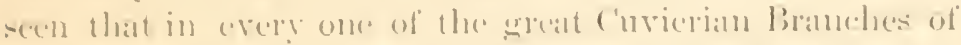
the anjmal kingrolon-cren in that which contains man-

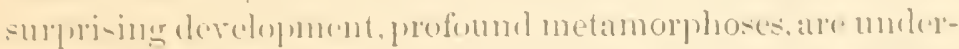

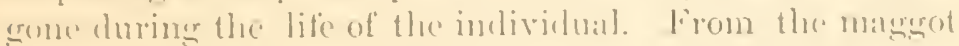

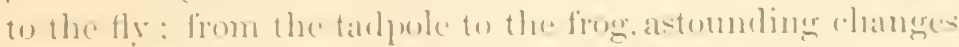
talke place in forms, strtedure, and arlaptation to surrommeling- within a few day- or monthe and before our very cyes. IVe have - -

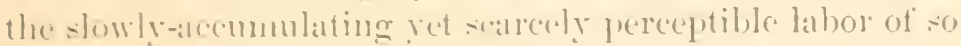
scemingly is-ignificant an olject a- the carth-worm. With such fitet-betore you atu you dombt that changes like tho-e experiencerl he the individual in se short a time ma! have

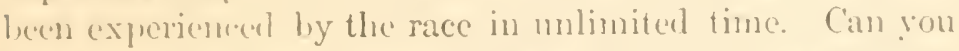
longer wendrer when nature thrusts upoun hisn at every turn such and a thom-indel other evidences of development that the avolutionti-t helinges in it as a principle-al law- the only molle of creation! ll permits us

\footnotetext{
. To praim the pa-1. yes in the pay portray such shapes as ecem rlim proplect of lo day."
}

fund had not palatentoluer recently given us alsoolute proof

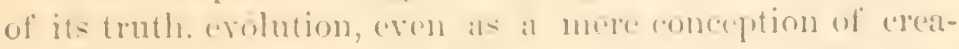
tim, intinitely transcends all formere conceletions. The tree

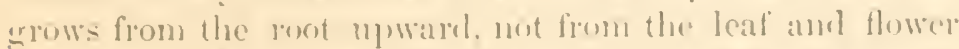
lownwarl. Man has grown up foum a part salvagery, mot from perfection ilownwarel. Wire I to assure you that you were all created full-bearded amel full-dlessed hy some miraculous fiat, insteal of having he(') hurn of farents and 
developed from infancy through childhood to maturity, you would flout the assertion as that of a crazy man. Yet I do assure you that the similar miraculous creation of a species out of nothing so persistently believed in by many even to-day, appears not one whit less absurd to the well-informed naturalist.

In reflecting on what I should say to you to-day, I found this question constantly running through my mind: "Why is it that so little is known in the most intelligent communities of the commonest things around them?" It is, I take it, because, first, the teaching of natural science is so generally neglected in our public schools and other educational institutions. The child is taught something of the elephant. the lion, the tiger, and of other tropical quadrupeds which it is rarely destined to see except in some menagerie, and nothing of the many that it meets with in every day life; so that many a man is inclined, with Carlyle, to lament in afterlife that no schoolmaster of his had taught him the grasses that grow by the wayside and the little neighbors that are continually meeting him with a salutation which he cannot answer as things are. The importance of things is too often measured by their size. Yet the unseen worlds in the starry firmament which the astronomer explores with his telescope are no more marvelous than the unseen minims of creation which the naturalist may explore with his microscope! What is true of animals is true of plants and of all other organisms. Happily much progress has been made in this direction during the past few years, the tendency of the times being strong in the direction of more science in our schools; in other words, of that erlucation that will give more perfect knowledge of ourselves and the world we live in.

Education should be a living thing, animated by modern impulses, molded by modern thought, and governed by modern wants, and I think the people of the country are to be congratulated on the establishment of this National Museum, which is founded on so broad a bases that it cannot fail to exert a marked influence in promoting such education as I have indicated. 
Again, the ordinary man of aftairs is very apt to look upon the study of natural seicuee at trivial heratue of $n 0$ possible use to him in his husiness. The "ry of "ui bono is constantly ratised angainst it, lut on equal groumels it might be raised aganist listory, polite literature, and many othere stndies. To these-if such there lo among my anditorswho take so narrow a view of the subject, I would say that to the latrere portion of om population, which represent the agricultural industry on which all our prosperity as a nation depends, a knowledge of matural science is of the utmost practical value, while to all it will afford hoth health ancl phleasure als a recreation from the cark and grind of business life. In this country, more particularly, the mind of bm:y man finds no relicf in idleness, and on all sides we sce men who, indiflerent alike to the noblest works of art and the sublimest teathing of nature, accumulate fortune only to find that they are physical wrecks and mentally incapalule of deriving pleasure or stimulum from anything but still further aceumulating-slaves, in finct, to a sordid habit. How many women, also), lrift into a sybaritic life and come to find relief from cmui only in one constant romul of artificial fleasure which ends too often in mental and physical misery. There is no better prophylactic agranst such dangers; no surer eure for that todium vilos which haunts so many, than the study of natural science. There is an inexpresible charm in animated nature for those who have learned to mock her secrets. They, indeed, "find tongues in trees, looks in the ruming brooks, sermons in stones, and good in ererything." They see everywhere around and about them-in carth, air, sky, anel water-volumes inspired by the great anthor of cur heing;

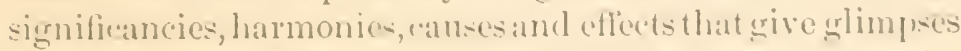
of the very thought of the Creator. In Williamson's words: "Those who have the power of understanding the wonders of nature derive great happines from learning to employ it. It is like the pleasure which a mian of healthy and vigormus frame experiences in climbing a momntain peak, and in en- 
joying, in proportion as he rises, a wider and more commanding view of things below."

" This is human happiness!

Its secret and its evidence are writ

In the broarl book of nature. 'Tis to have

Attentive and believing faculties,

To go abroad rejoicing in the joy

Of beautiful and well-created things;

To love the voice of waters, and the sheen

Of silver fountains leaping to the sea;

To thrill with the rich melody of birds,

Living their life of music; to be glad

In the gay sunshine, reverent in the storm,

To see a beanty in the stirring leaf,

And find calm thought beneath the whispering trees;

To see and hear and breathe the evidence

Of God's deep wisdom in the natural world!"

I hope I have said enough to show that deep insight into Nature's truths is not only of practical value, but that it is in other ways beneficial and elevating. Nor is it satiating! One never tires of the recurring seasons, and one never tires of any scientific research, for the simple reason that there is never any end, but always something new to learn-something more wonderful to unfold.

\section{Says Lowell :}

I grieve not that ripe knowledge takes away

The charm which Nature to my childhood wore,

For with the insight cometh day by day,

A greater bliss than wonder was before.

To win the secret of a weed's plain heart,

Reveals the clue to spiritual things;

The soul which looks within for truth, may guess

The presence of some unknown heavenliness! 


\section{P'AUI, BROCA}

\section{ANI) THI: FRENCII SCHOOL, (OF: ANTIIROPOLOGY.}

Lecture deliveret in the Sational Mtusem, Wishington, W. C.. April 15. ISS2.

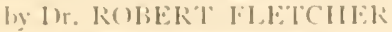

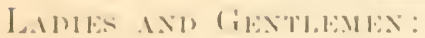

Vou have heame a great deal in these lattul days of the serence of Anthopologrand andile many of you, doululesi.

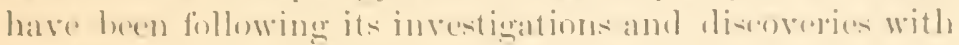

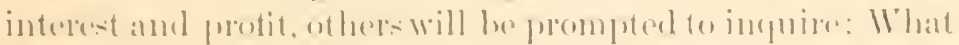

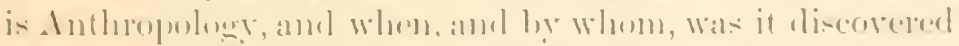
or inventede? 'Tu the first part of the puestion it is menecesary for me on reply, as Protexise Malson, in the secomel

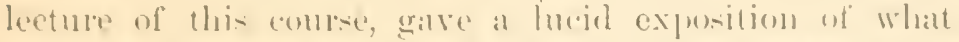
constitutes the selenee in question: lut the ransul of its

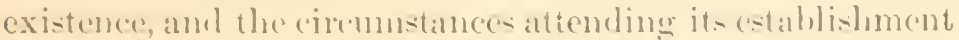
amb recognition in the sejentific world, it is the purpose of this lecture consedisty to ixplain.

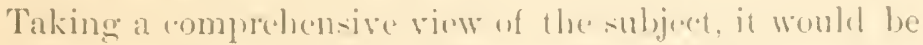
correct to say that anthropology has exioted since the earliest days of human civilization. C'assical literatume sums

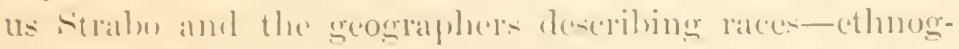
raplude: (ralen and his followers as anatomists and plursicians-biolowists, as we shomlel (all theme now: and l'lato and the metaphroicians as perchologists. Whe gro hatek to Justinian for the fir:t recorels of an important limele of

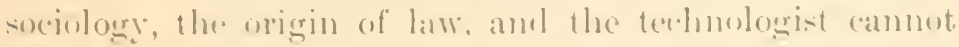

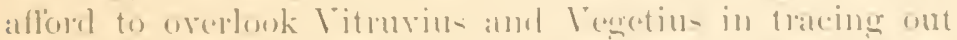

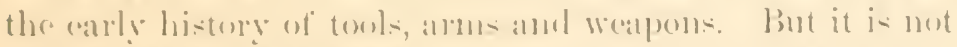
with the separate scienere which torethere form what wo now

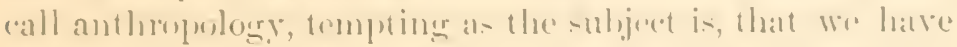

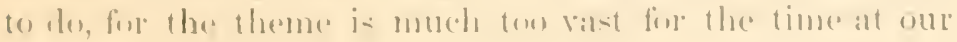
|li-|m-il|.

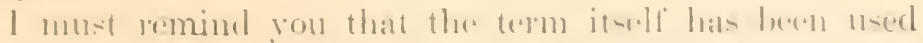

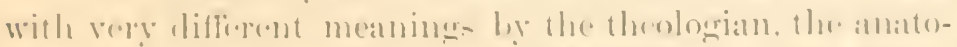

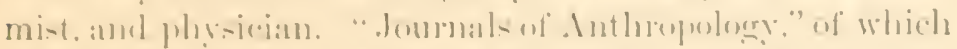

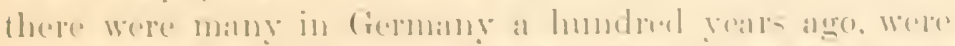

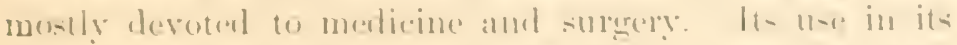

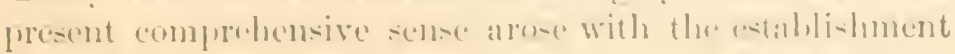


of the Paris Society of Anthropology, about twenty-five years ago, and its fitness for the purpose was so manifest that it has superseded to a great extent the narrower titles of ethnology and archæology. At the present day there are Societies of Anthropology in nearly all the eapital cities of the world. They were all founded, more or less, upon the model of the Paris society, which is acknowledged as the parent from which this flourishing progeny has sprung.

It will be more convenient for our purpose to begin with a description of these associations as they now exist, and then, in a brief biography of the eminent Frenchman who founded the Paris society, show you in what manner the science of anthropology received its birth and baptism.

The first French Society which made the study of mankind the especial object of its enquiries, was founded in Paris in the year 1800, and was known as La société des observateurs de l'homme-the Society of Observers of Man. From their programme, and from the meagre reports of their transactions which appeared from time to time in the Magasin encyclopédique, it is evident that the natural history of man chiefly occupied their attention. In 1503, this association was united with The Philanthropic Society ( $\mathrm{La}$ société philanthropique) and lost its scientific identity. In $1 S 38$, there was founded in London, under the presidency of Sir 'Thomas Fowell Buxton, the leader of the party advoeating the abolition of slavery in British dominions, a Society for the Protection of the Aborigines. The object of this association was political and not scientific, but one of its members, a Mr. Hodgkin, risited Paris a year later for the purpose of establishing a French society on the same basis, and came into communication with many eminent men, among whom was the celebrated naturalist, William Edwards. The attempt to found a French abolition society failed, but the interest excited in the cognate subject of race led Edwards and his friends to establish the Ethnological - Society of Paris, $(a$,$) whose existence was officially authorized$ by the Minister of the Interior, in August, 1839. This society published two volumes of memoirs, and one, of its 
transations. The work it alehered was exeellent in kind,

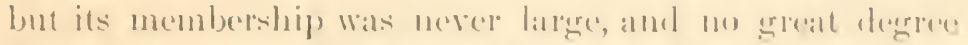

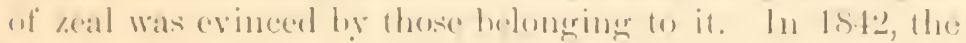

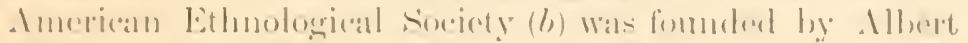

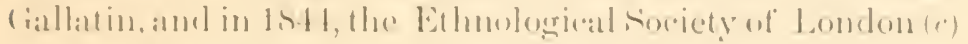

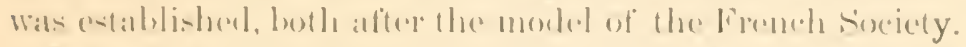

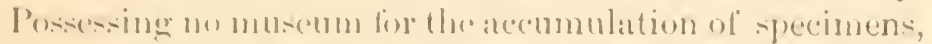
the bihnologial Socinty of l'aris devoted itoplt mainly to the investigation of (entain latees, their habits and enstoms. Infortmately, tom, for its prosperity, it tork uj with great

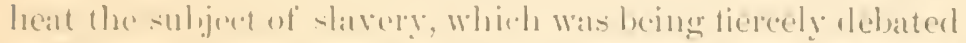

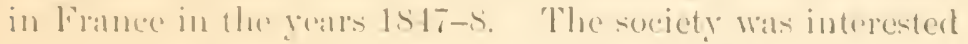
moly in the question of race, and of the single or multiple mpigin of mankinel, Jut an absml belief bexane gencial

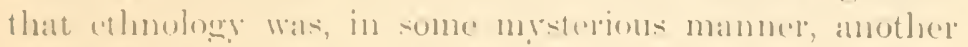
name for abolitionism, and this peromlice stmpived to be an obstatele in the atablishment of the Anthropological fociety, tern veats: later.

What the ciremmstances were that led to the foundation of the latter society, fhrough what discouragements and

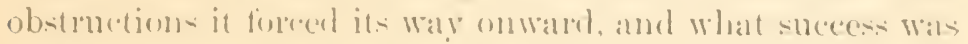
at last arelieved, will lx descolibed in the hographic sketch uf Brocal which will he presently antempted.

The time was ripe for the unclertaking. The socicty was

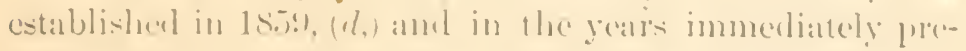

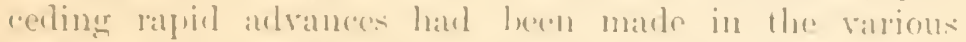
branches of knowledge which enetitute anthropology. In

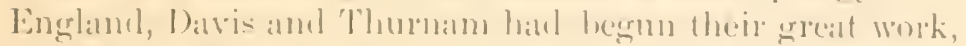

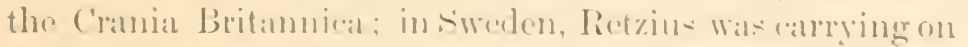
his remarkable studies in aranolory: Morton, of Philadelphia, having amassed the rollection of skull- which was, for many years, the richest crantolengical rollention in the world, had produced lis important work, the r'muja Amer-

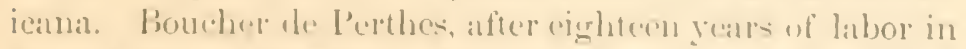
the yuaternaty depusits of Abbeville, hat alt has trimmphed orere ridicule and malice, and had crreat antiguity of man accepted by tho loarling palicontol-

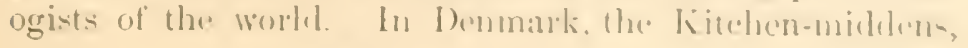


those silent chronological records of the devoming appetite and progresive luxury of primesal man, had been explored and described by Worwilde and Thomsen. In switzerland, the unusual subidence of the waters of the lakes had brought to light the relies of the lake-dwellers; and, not less memorable, on the 24 th November, 1S59, there appearerl in London a modest looking rolume which has probably exerted nore influence on scientific workers than any one book ever published-its title was: The Origin of Species, by Charles Darwin.

Prof. Huxley, speaking of this occurrence twenty years later, said:

"It was only subsequent to the publication of the ideas contained in that book that one of the most powerful instruments for the adranee of anthropological knowledgenamely, the Anthropological Society of Paris-mas founded; afterward, the Anthropological Institute of this country and the great Anthropological Society of Berlin ame into existence, until it may be said that, now, there is not a branch of science which is represented by a larger or more active body of workers than the science of anthropology. But the whole of these workers are engaged, more or less intentionally, in providing the clata for attacking the ultimate great problem, whether the ideas which Darwin has fut forward, in regard to the animal world, are capable of being applied in the same sense, and to the same extent, to man. That question, I need not say. is not answered."

It may seem almost superfluous to explain the allusion to the lake-dwellings and the kitehen-middens, but some of the younger nembers of this andicune may be glad to learn what is meant by thowe terms.

In Switzerland the winters of $185 . ;$ and $185 t$ proved to be so dry and cold that the usual spling freshets in the rivers were wanting, and the level of the water in the great lakes was lower than hard ever before been recorded. Accident led to the discovery of some ancient piles, and other evidences of man's work. The result of long-continued investigations may be brietly stated, as follows: The Pfahlbauten, or pile-works of switzerland, were villages built on piles 


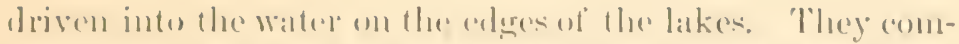
municated with the land by one of more bridges, and there is 110 dombt that defonee against wild animals as well ats human enemies was the motive for this mothod of erectime

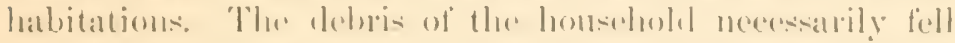

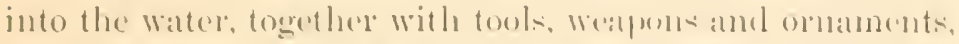

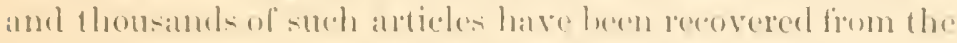
soil of the lakes atomed these pilas, together with the bones of animals which harl served for forml. The larger number

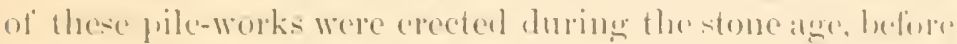
the use of metal was known to man: hut in II (estem

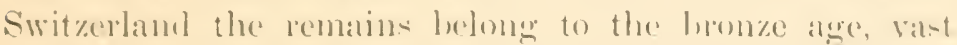
numbers of henze implements aml ormandents having leen recovered from them. From one settement alone sono bronze hair-pins, such as pasant women adorn their hatre with, were obtained. Proynom has mate an extimate of the population of these lake-rlwellings; lis figures are 92,000

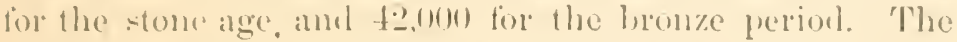
adrlition to our knowlulge of pe-historic man ohtained fiom these Phahlianten has lxe'm of incaleulable value.

Aerilent, in like mannor, disew attention to the real in-

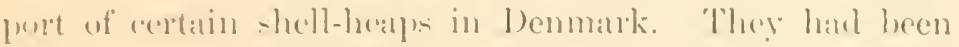

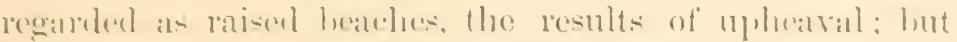

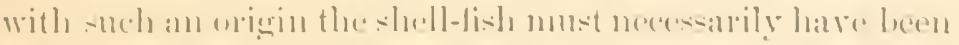

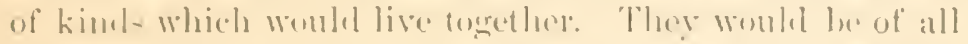

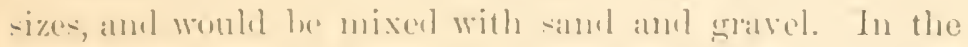

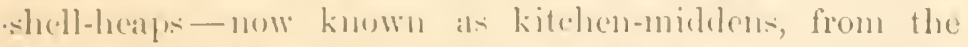
Danish Kjokkrnmödding, kitchen-refuse heaps-the shells

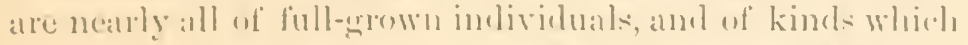
do not live togrether, and mo sumb or eravel was fomml in them. Flint implements amb bomes of amimals, linl-aml fishes alommd in thrm, and it berames evident that these

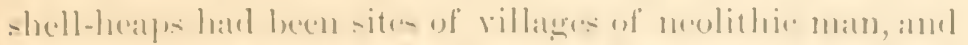

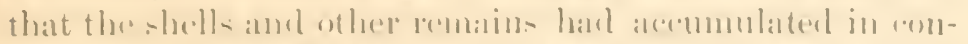

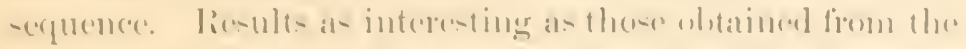
exploration of the lake-elwellings fislowed, and the museums

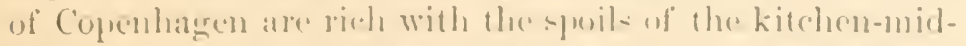
lens. similar -hell-hraph halk lecen fomml in almo-t all countries. 
It was under the auspices thus outlined that the Society of Anthropology of Paris began its career. Its success was assured as the quality of its work became known, and within ten years, in all the ehicf kingdoms of Europe, societies of like purpose were organized, and are in the full tide of prosperity and active occupation at the present day.

And here it may be well to explain why the term "ethnology" has been so generally superseded by the term "anthropology." The former, as you are aware, is the science which treats of the races of men. Limmeus and Buffon were its chief founders, but Bhmenbach moulded it into the shape which it yet preserves. It is to him that we owe the five divisions of the human race which still maintain their place in our school-books, though they have long since been discarded from scientific description. Ethmology classifies mankind according to certain resemblances of features, color, hair, dress, weapons, and the like; anthropology takes his anatomical structure as the basis of comparison. Broca, speaking of the two, says: "Ethnologists regard man as the primitive element of tribes, races, and peoples. The anthropologist looks at him as a member of the fama of the globe, belonging to a zoülogical classification, and subject to the same laws as the rest of the animal kingdom. To study him from the last point of riew only would be to lose sight of some of his most interesting and practical relations; but to be confined to the ethnologist's views is to set aside the scientific rule which requires us to proceed from the simple to the compouml, from the known to the unknown, from the material and orwanic fact to the functional phenomena."

Yon were told in a preceding lecture that ten distinct sciences were included under the name of anthropology; ethnology, much shorn of its significance, being one of them. You will see then that the more comprehensive term was necessary to indicate the scope of the investigations pursued.

I propose next to give you a suecinct account of the societies which were founded after the model of the Paris association. 


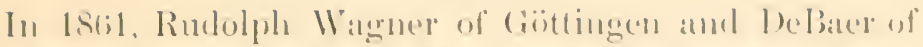
St. Petershurght organized a Cieman . Inthropological Asisociation, (e,) which was to meet erery second yoitr in at German city. Its first meeting was held at Göttingen, but the deathof Wagner, which took place soon after, intermupted its further progres:

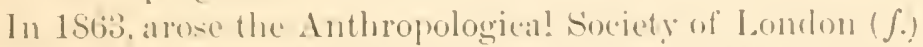
It wats formed hy the secession of a large number of mombers of the Ethmological society, and speedily becante so sucersful that it at one time numbered solo nembers. It continued to exist moler its original title mutil 1st1, when the Ethnologial suciety consented to unite jeself with its ambitions offepring and the designation assumed he the united associations was: The Anthropological lustitute of (ireat Britain and Ireland (\%) The Ethnolowiral Society published 13 volumes of 'Tansiations; the Anthropologieal Society published ! rolumes, and the Jommat of the Anthropological Institute has now entered on its twelfth year.

In 1stis, the Anthropological sinciety of Madrid (h) was established, its first meeting being held om 1)ecember 17 . Gwing to political complications, so rommon in that wnhappy country, and to the opposition of the pricsthool, no further mertings were permilted, and the soretr, which harl attined a membership of 300 , continued in a languish-

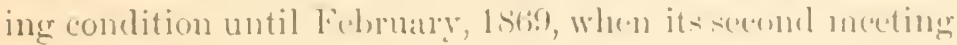
took place.

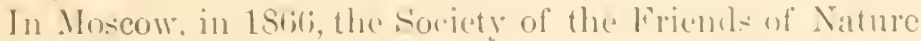
(i) wablished a section of anthropology: Endowed with anple resenues this section hats been as eflieinent as if it hat

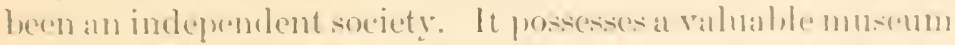

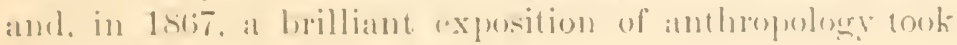
flace moler its management.

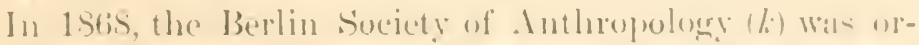
ganized and speedily attained foremost rank fom the imfortance and extent of it investigations. Virelus, the illu-trioun physiologist, statesman and scholin, still presiden over its meetings. The society pullishes the dournal of Ethonology. 
In 1570 , the Anthropologieal Society of Vienna $(l)$ was founded, and at their first meeting, February 13 , the opening address was delivered by Rokitansky. The Society publishes its own transactions.

Italy was next to continue the good work, and, in 1S71, was established the Italian Society of Anthropology and Ethnology $(m$.) Their transactions are reported in the Arelives of Anthropology and Ethnology, a monthly journal, handsomely illustrated, which is published at Florence under the editorship of Mantegazza.

In 1571, in the city of Tew York, there was founded a society known as the Inthropological Institute of New York $(n$.) Its sole work was the publication of its Journal, "Whom the Gods love, die young," ways the Greek proverb: the "Jomrnal of the Anthropological Institute of New York" must have been the especial object of celestial regard as it expired with its first $111 m$ mer.

In 1STT, Poland entered the field, and the Aeademy of Sciences of ('racow $(o)$ established a section of anthropology which publishes its own journal.

In 1579 , the Anthropological Society of Washington, D. C., $(p$,$) was foumded, and has continued to thrive.$

During the present year, Dr. Aurèle de Torok, of Hungary, who had been for some time studying at the Paris school, was placed in charge of a section of anthropology in the University of Buda-Pesth, with instructions to form a nuseum.

There are many subordinate societics besides those described; they are generally affiliater with the societies of the capitals. For example, there is an Anthropological Society at Liverpool, another at Oxford, another at Manchester; one at Lyons, one at Bordeaux, and even in the Isle of Man there is a rection of anthropology in the Manx Society of Siciences.

Another important result of the interest felt in these pursuits has been the organizing of congresses of anthropology, meeting in different cities at stated intervals.

There is the German Association for Anthropology (g) 


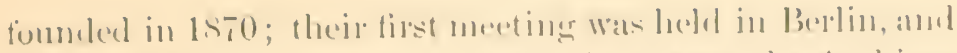

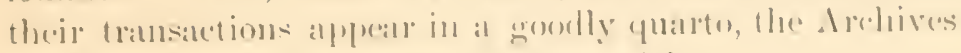
for Inthrepuloge publisherl at brumswick.

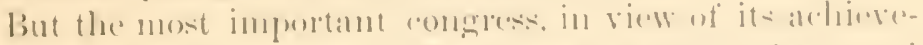

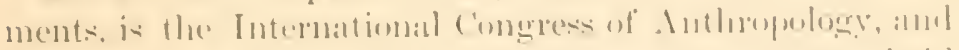

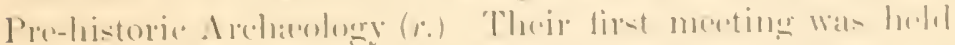

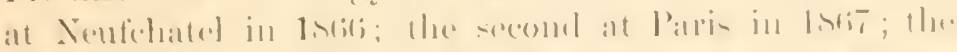

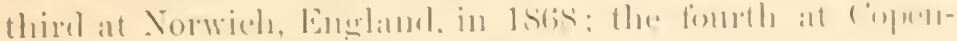

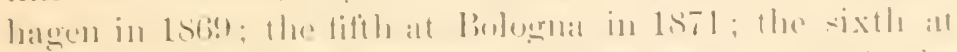

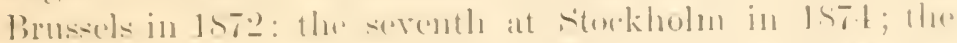
eighth at Bunla-l'exth in listi: and the nimtle at lixbon in 14isl. I believe the mext meeting is to be held at Vendere

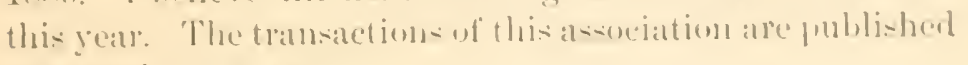
after each conerges.

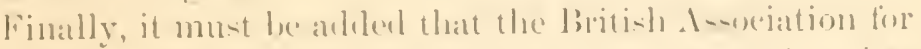

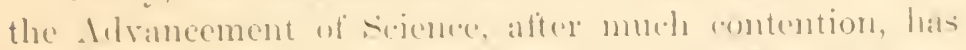

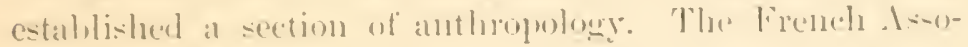

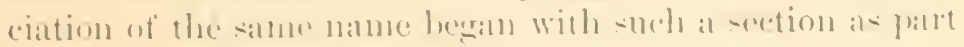
of itsoriginal oreanimation.

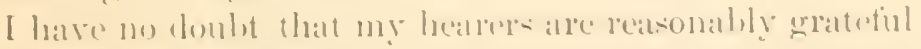
that this dry essumeration of socicties and thede prouluctions has come to an end; lut it has beren -homm that all of these

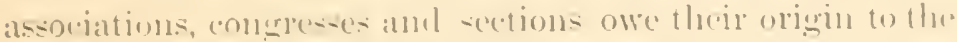

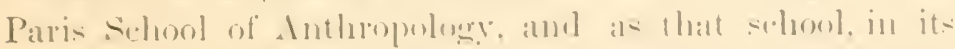

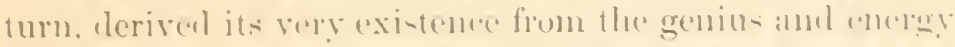

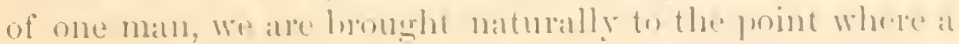
seteh of the life ame work uf the fommler of Viropean anthropulogy commen properly into vin plan.

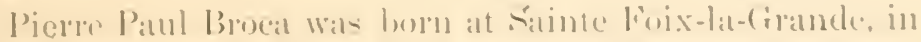

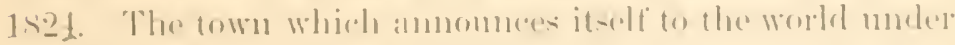
this peotentions title is situatorl in the department of the (iimomle, wn the bank of the Dordogrue, forty milen timm

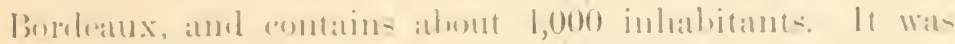

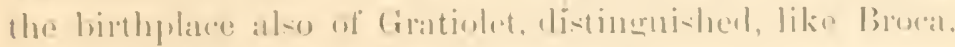

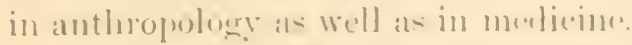

It is always interesting, and, indeed, esential to the slue estimation of a disting!nialınl man, to state what ma! le 
known of his parentage, and of what it is now the fashion to call his early environments.

Broca's father, Dr. Benjamin Broca, was an army surgeon, and had served throughout the memorable war in Spain under the first Napoleon. The campaigns over, he returned to his native town where he married and settled down to practice his profession. He was a man of marked traits of character; of unflinching probity and courage, and charitable to an extreme.' From him his son derived his taste for the natural sciences as well as a grave irony which characterized them both The son used to quote an ironical remark of his father's which is amusing enough to be related. The elder Broca flourished in the time when the doctrines of Broussais attained such astonishing popularity, and blood-letting and rigorous diet were the treatment in vogue. Against these views, Dr. Broca fought valiantly, and it is told of him that after a consultation over a patient prostrated with typhoid fever, hearing the physician in eharge prescribe, as the only nutriment, a broth to be made of frog's feet, Brocal turned back from the doorway and said, "and above all things, be sure to skim off the fat!"

Dr. Broca, senior, aequired a large country practice, but which was not very lucrative, for his rule was to charge the rich but little, while to the poor he gave his services and paid for their medicines. When, in later years, after the death of his wife, he remored to Paris to reside in the house of his distinguished son, the whole country round ras in sorrow for his loss, and his indigent elientage presented him with a silver-gilt cup inscribed "To the physician of the poor."

An amusing story is still told in Sainte-Foix of this excellent man which exemplifies his unfailing benevolence. At a late hour, one cold and dark winter night, a peasant requested him to visit a person taken seriously ill, in a distant liamlet. The good doctor left his comfortable fireside without hesitation and accompanied the man along a lonely pathway, inacessible to all but pedestrians. Arriving, at length, at a small eluster of cottages, the man turned 


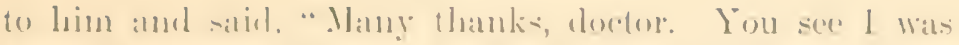

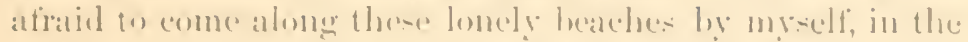

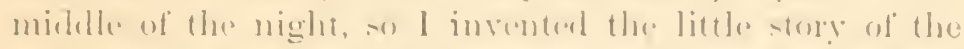

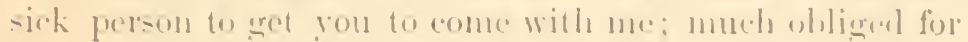

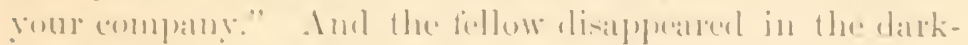

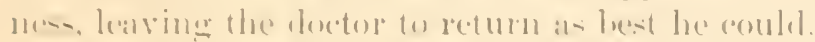

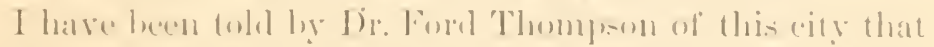

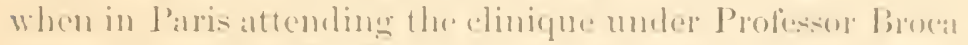
at the hospital of l.a l'itio. la was-stuek with the alpuall-

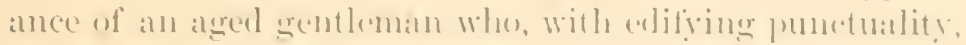

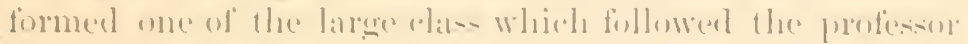

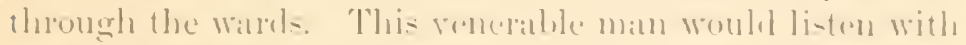

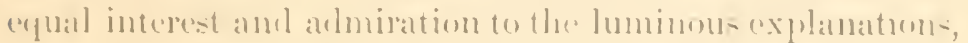

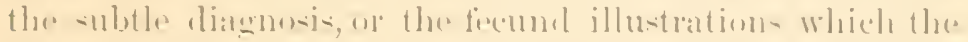

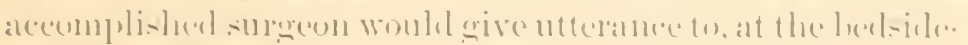

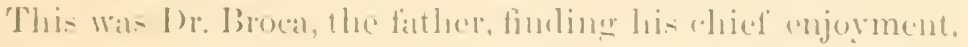

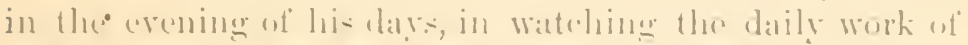

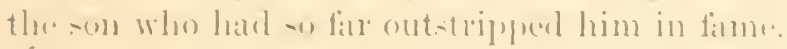

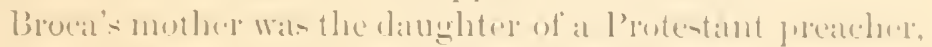

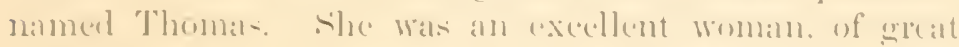

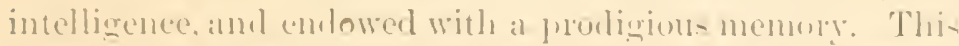
latter yuality wat inherited hy her sun. The broras were

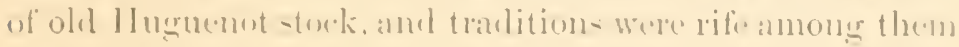

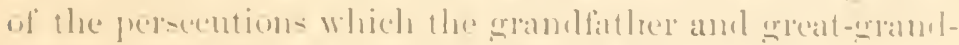

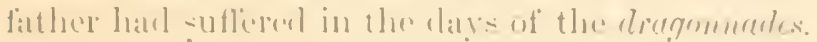

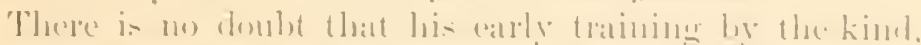

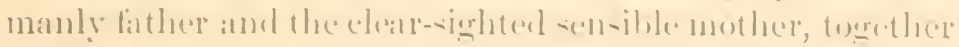
with the tralition-ul their family hi-tory, herel in the youne

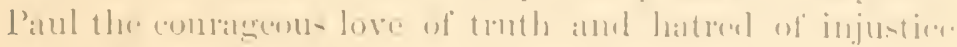

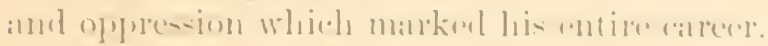

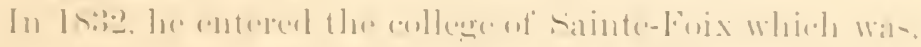

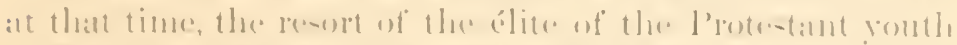

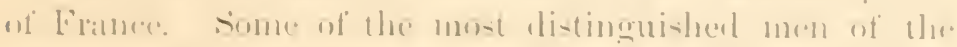

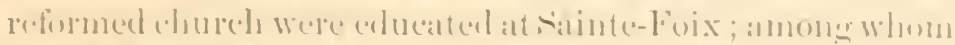

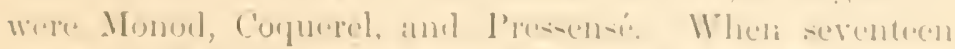

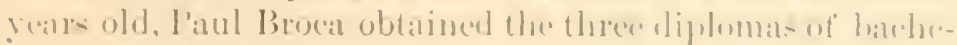

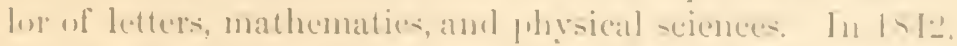

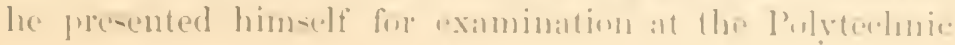


School, intending to make physical sciences the basis of his future work, but his father, loth to see his own practice lost to the family, persuaded his son to adopt medicine as his profession. An additional motive for his compliance was the recent death of his only sister, a very lovely girl of great promise, whose loss made the parental home very lonely. Broca did not trouble himself about his carreer; he used to say, in after life, that in any occupation, he could have made such a place as his abilities merited; and with his healthy organization and unparalleled capacity for work, it is probable that he was right.

He went to Paris, and entered his name at the Faculty of Medicine, and thus began a career mequalled for the rapidity of its progress. In 1St3, he became an citcrne at the hospitals, and in 1S44, he became an interne. He was then twenty years of age, a period at which most students of medicine have only entered themselves. In $18+8$, he became prosector of anatomy, and obtained the silver medal of the Public Assistance. He graduated as Doctor of Medicine in 1849; the Academy of Medicine decreed him the Portal prize in 1850 , and, in $185 \%$, he was named Assistant Proffessor of the Faculty of Medicine, and Surgeon of the Central Bureau, being then only twenty-nine years old.

In 1847 , he was elected a member of the Inatomical Society of Paris, and for many years he was the most actire of the distinguished young men who raised that society to its present pre-eminence. His researches into the histology of cartilage and bone, with the aid of the microscope, of the use of which in anatomical researches he was one of the strongest alyocates, have remained unsurpassed of their kind to the present day.

In the Society of Surgery he was equally active, and its transactions bear witness to his zealous labor's.

It is not within the scope of this lecture to describe his surgical or physiological work; the general result, in the number of his productions, will be given at the close. It must be said, however, that his brilliant investigations into the localities of the functions of the brain led the way to 
1he discoverine and appliations of Hitaig, Ferrier, and Chareot: of his largere work-, the 'l'heatise on 'lumors, and

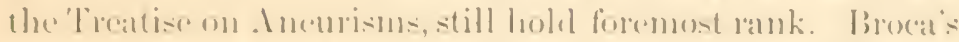

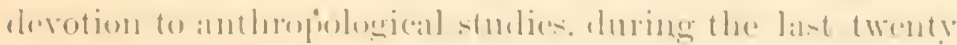

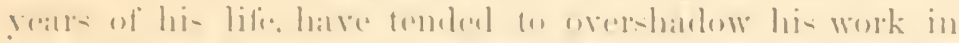

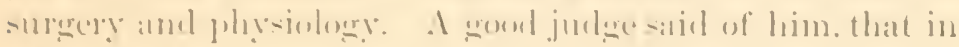

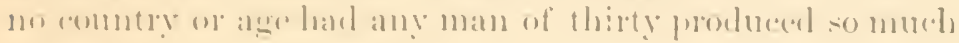
of value in -l112ury ats he.

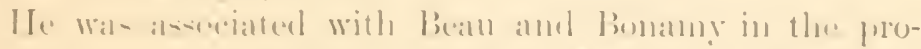

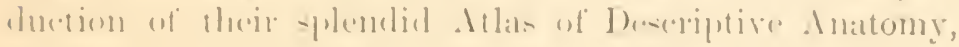

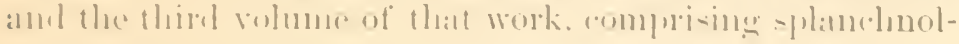
ung. in entimely lis- work.

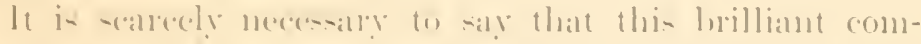

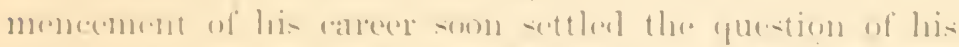
returm to the batsk of the Dorlogne. The father wa-

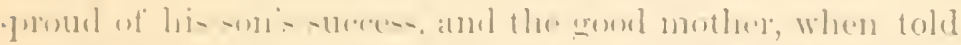

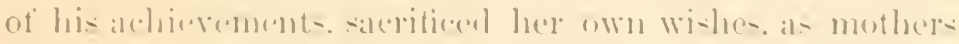
do. and salil. "my pride is gratified, but not me heart."

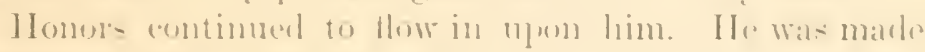

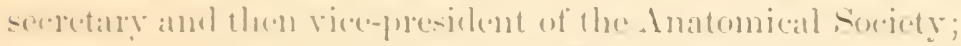

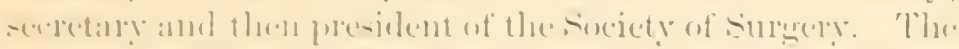

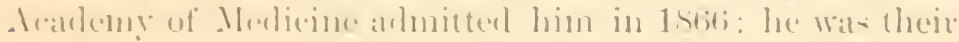

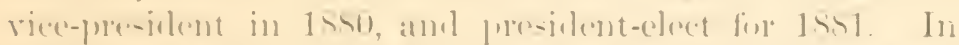

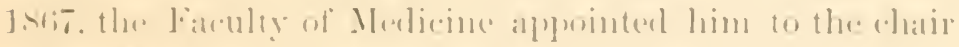

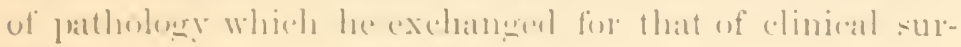
wery.

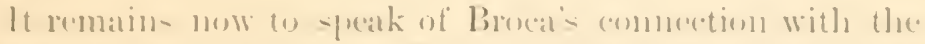

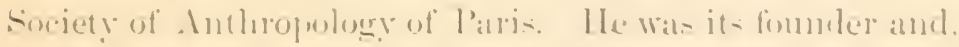

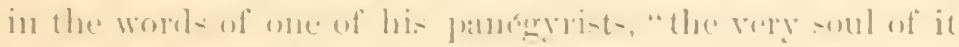

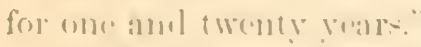

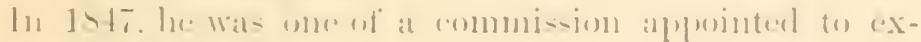

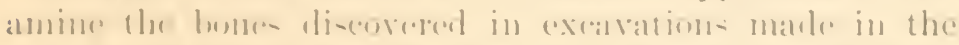
ancient rhurele of the celestins. Th dratwing up thi- re-

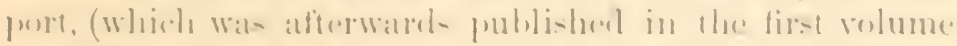

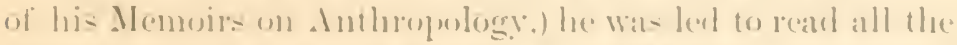
lonk- lee could find, and they were not many. upen the sul-

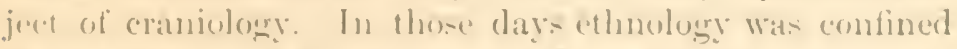

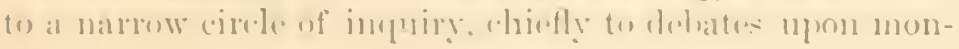


ogeny and polygeny, or the doctrine of the origin of the human race from one source or from many. The Ethnological Society of Paris, founded, as I have before stated, by William Edwards, having ended its discuswions upon this subject, and finding nothing more to say, itself came to an end in 1s.ts. Ten years later, Broca, who had arrived at some ronchusions upon humam hybridity which he clesired to make known, communicated them to the Society of Biology. But the young discoverer had yet to learn what fusilanimity conld do to retard investigation. His remarkable memoir demonstrated the mulimited focundity of hmman hybrids, and as this was opposed to the doctrines of the monogenists, Rayer, the President of the Society, requested Broca to desist from further communications. The memoir "On animal hybridity in general, and on human hybridity in particular," was published in the Journal de. la physiologie. It was afterward translated by Dr. Carter Blake for the London Society of Anthropology, and was published in their memoir's. This condition of things made it evident that a new society was needed, and Broca conceived the idea of a Society of Anthropology.

Broca's plan was to start with not less than twenty members. Six from the Society of Biology joined him, but others, including the members of the defunct Society of Ethnology, turned a deaf ear to his solicitations. After a year's efforts, he had only nineteen signatures, inclurling his own. He met with every obstacle from those in authority; M. Rouland, the Minister of Public Instruction, sent him to the Prefect of Police, who, in turn, sent him to the Minister of Public Instruction. Their purpose was to weary him out, for with the perspicacity usual in such functionaries, they firmly believed that the novel term, anthropology, covered some form of political conspiracy. Finally, thanks to the intervention of P'rofessor Tardien, a chicf of division of the prefecture of police was induced to authorize the nineteen to form their society and hold meetings. He held Broca, however, personally responsible-for anything which might be said by his associates which should appear to be an 
attack upen govermment, religion, or social order; and, to easure the realization of these prodent precantions, he

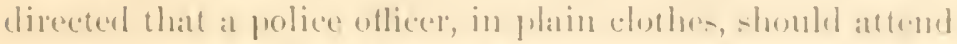
each neeting and report to the preferet the tentire of the procecelings.

Does not this sound as if we were discoulsing of something that took place mache Lomis yuatome, or Philip the

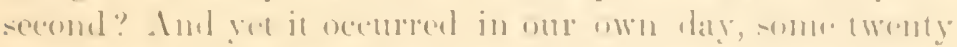

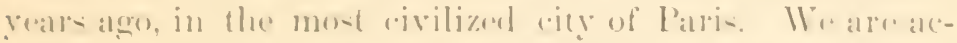

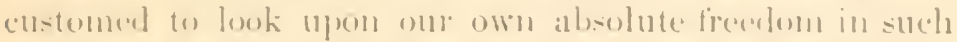
athajes at at matter of comses but it may not be muprotitable

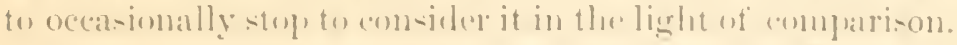

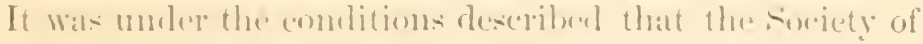

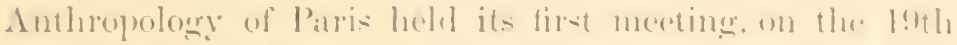
May, 1sis. The word anthropology was substituted for

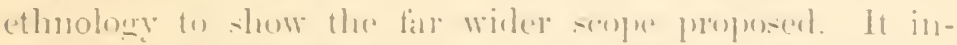

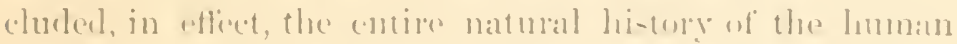

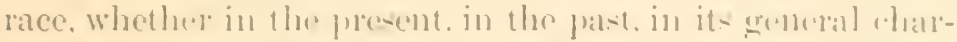
acters, in its suludivisions into races op ratreties, in it-orituin, or in its relations with the rest of nature. This programme

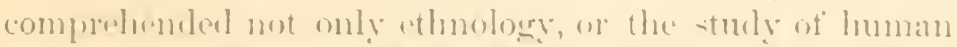

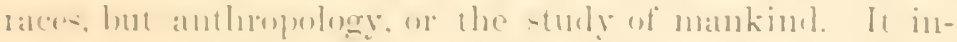

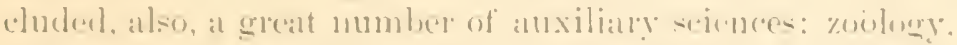

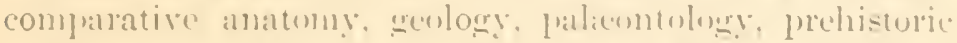

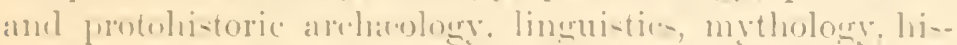

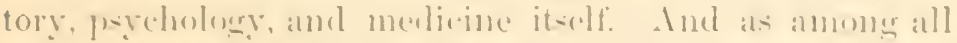
these liverse and divergent stulies it was necessily to estahlish some antral hasis, the formelers of the soredety, who

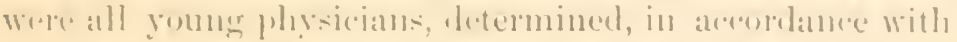

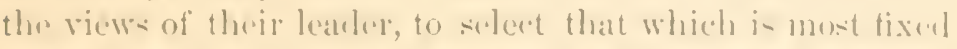
in man, namely, his organiation and functions; in a word, his anatomy and phe-ioluges.

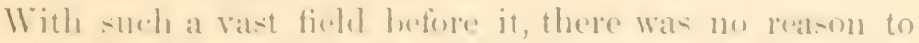
fear that the new society would peri-h for want of -t1-tonance like its predecesor, the society of Ethology. I- its

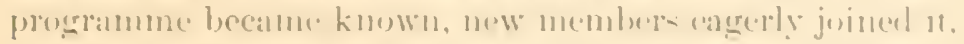
and when the first volume of its lubletine was published,

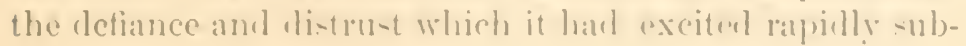


siderl. M. Rouland, the Minister of Public Instruction, deigned to authorize it in 1861 , and, in 1864 , it was recognized formally as a society of public ntility, by a decree of the Council of State. After this date, the attendance of the special police agent at its meetings was discontinued.

During the first three years of the existence of the society, Broca filled the office of secretary. It was a burdensome task for a man of his numerous arocations to undertake, but it was of the lighest importance that the transactions of the roung society should be edited with talent and appear with punctuality. Ife excelled in the diffieult art of giving the integral meaning, but without prolixity, of what was said in the ardor of debate. He was skillful in ignoring the common-places of the chronic speaker; the man who always "rises to give his riews," though he has generally nothing to communicate. These comptes rendus are master-pieces of their kind, especially when it is considered that they were written from memory, for he took too active a part in discussion to have time to take notes.

In 1863 , the increase of the Socicty made it necessary to appoint a Gencral Secretary, electable for three years; Broea held the office till his death. Professor Pozzi says, "Broca was the soul of the Society of Anthropologr. It was he who founded it, he who made it live through its first trying rears, and that by the preponderating influence of his incessant labor and the communicable ardor of his love for the growing science. The powerful influence of Broca, especially risible at the beginning of its career, was not less real to the very close, in spite of the care which he took to aroid the appearance of personal control. Even when he abstained from taking part in any irritating debate, his attitude, the few words which might escape him, his rote, infallibly indicated to doubting minds, upon which side reason, moderation, and justice were to be found."

Upon the establisment of his Society, Broca began a craniological collection and, thanks to the surgeons of the navy, with whom he kept up an active correspondence, it soon attained respectable dimensions. Nevertheless, a 


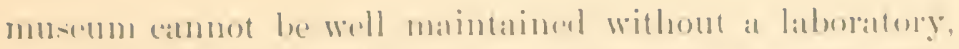

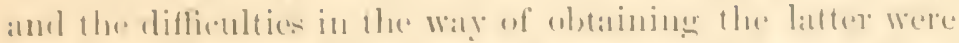

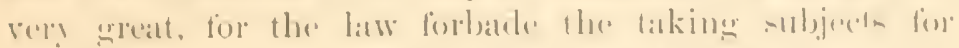

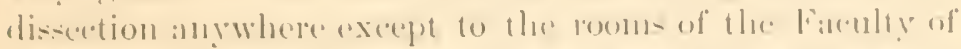

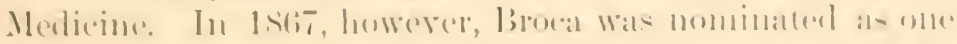

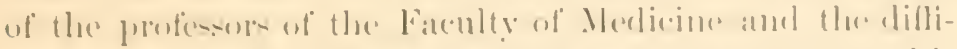

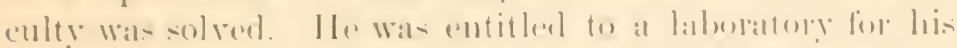

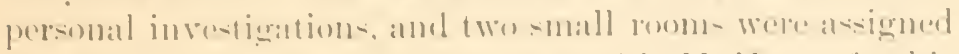

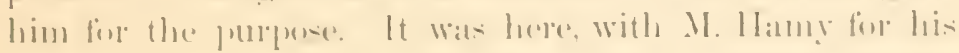

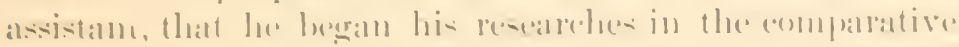

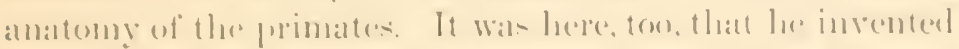

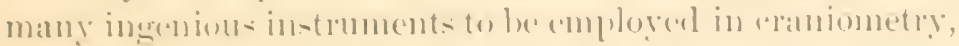
or the measmement of the simll. In rommertion with this espectial work of brocat is may lne well to give solme axplanation of what anstitutes craniometry without denht, the mo-t impurtant part of our labulatere work. Crani-

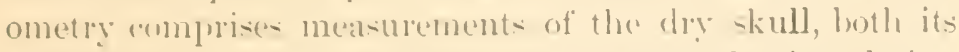

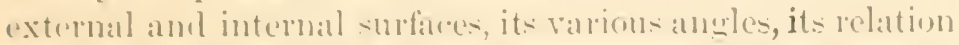
to the spinal columu, it: internal apacity and the proportion and weight of the hatin; (xternal measurements ate to be marle, whemerer pusilhle. in the living persun al-o. Moreovere these meismenents, to be of value, must he marle in larege mumbers. (1) that the atrelater. ol mean, may be

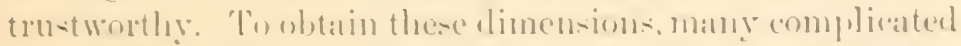
and costly instrument- lave beru invented, the greater

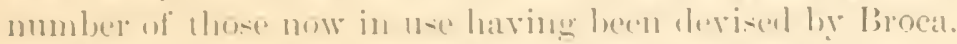
I harl intended to hring sume of there in-truments here in oreler to grive voll an illu-tration of the manmer in which

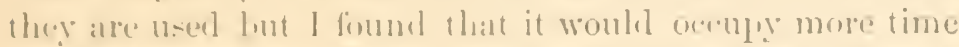

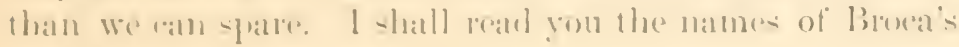
e.raniometrice imsentims.

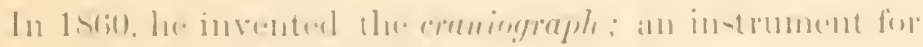
grivine the protile of the skull.

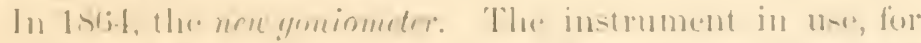

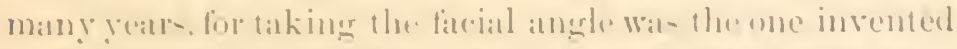

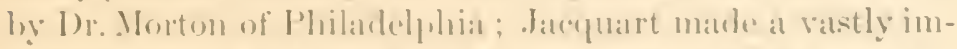
proverl instrument, lut birea's ganiometer had the merit of simplicity and dhaphes. 
In 1867 , he produced the stereagraph.

In 1869 , the cadre it maxima and the micrometric compass.

In 1870 , he invented the occipital goniometer, an instrument for ascertaining the angle of the back of the skull.

In 1573 , he brought to perfection a surprising number of instruments mostly for the investigation of the endocranium, or interior of the skull. A perplexing obstacle in the pursuit of cruniology was the difficulty, or rather, impossibility, of obtaining measurements of the interior without sawing open the cranium. This would spoil the specimen and could not, of course, be permitted. The instruments about to be mentioned were to be introduced through the occipital foramen, the large aperture in the base of the skull.

The cranioscope enabled a bright light to be thrown upon the interior of the skull by means of a mirror and lamp:

The porte-empreinte intra-cranien, or intra-cranial molder, is an instrument charged with a piece of wax by which a mold can be obtained of various portions of the interior.

The endograph is an ingenious contrivance for tracing on paper the curvatures and outlines of the endocranium for comparison with the external surface.

The millimetric ioulette is a small whecl, graduated in millimetres, for measuring the curred outlines on tracings.

The endometer is an instrument for measuring internal diameters.

He invented, also, the sphenoidal crochet and optic sound; the pachymeter, an instrument for measuring the thickness of the skull at any point; the turcica crochet; the acoustic sounds; the craniophore; the craniostat; the facial demi-goniometer; the auricular goniometer; the flexible bi-auricular square; the cyclometer; the facial median goniometer; the orthogon; the flexible goniometcr; the goniometer of inclination; and the tropometer for measuring the degree of torsion, or twisting, of the humerus, or arm bone, a racial characteristic of importance.

I fear this list of names has been rather tedious, but it is not only pertinent to the subject as illustrating Broca's mechanical ingenuity, but it may enable those present who 
have no special acpuaintame with aranolugy te form some

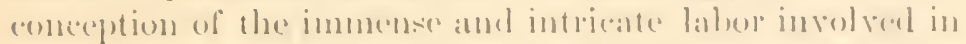

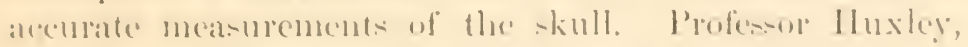

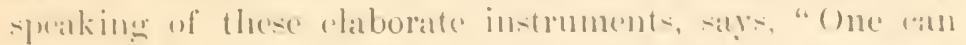
not nerention the name of Brome withent the geveatest gratitude:"

'Thi-, then, wan the herinning of the Laboratory of . An-

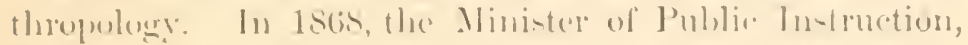

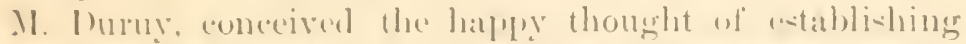

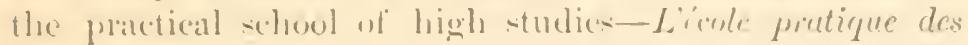
hentestudes-by giving an anmal allow:anee and an ofti-

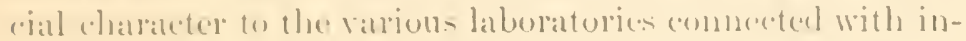
stitution of learning. Brocal - laboratery was included. He al onee in-tituted a s-ytem of traching which attracted

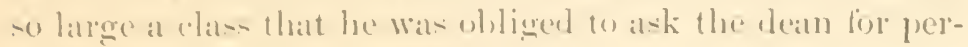
mi-rion to nor a lareme theatre.

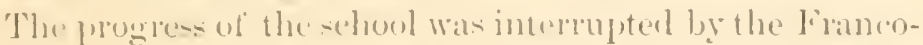

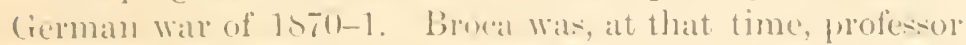

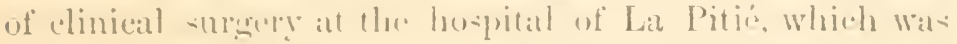
from the very lecginning of the sisere of l'aris erowdenl with

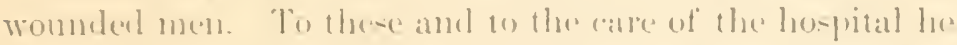

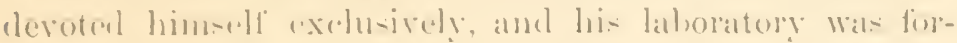
saken. Ho lated been one of the three directors alppointerl to take rhallere of the Public Assistanere. buring the dars of the Commume, for which, as stoling republicall and

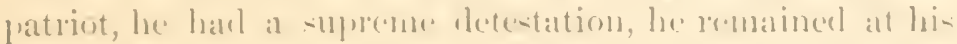
post in l'ari-, taking alle of the pationts -till in his low-

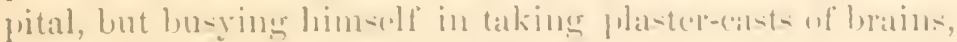

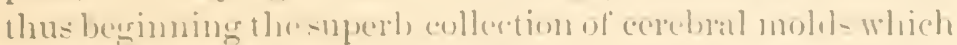
is now to beseen in the Murien Brocit. The l're-ielent of the

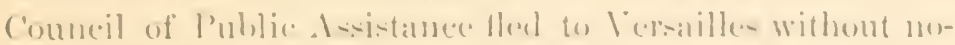
tifving broca, whe wat the vice-pre-inlent, and leavines the

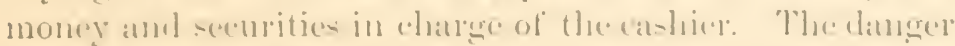

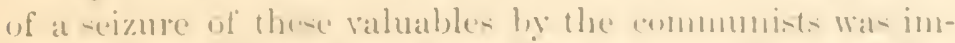
minent, and Brome determined to satve thems, if prosible.

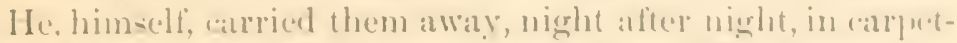
bays, and concealed them at the horpital of lal chariti. by the and of the direetor. He wate eareful to leatre shror or 
four thousand francs in the safe, and, much to the disappointment of the insurgents, this was all that they found when, a day or two later, they made the anticipaterl raid. Apprehensive that the treasure might, in some way, be traced, Broca devised a bold scheme for its removal to V'ersailles. A wagon loaderl with potatoes started for the hospital of Irry with the precious carpet-bags concealed undermeath them, and as soon as it had safely passed the ontmost guard, the wagon was turned toward Versalles, which it reached in safety, and the bags were duly delivered to the over-prudent president. The amount thus saver to the government by Broca's firmness was seventy-five millions of francs, $(\$ 15,000,000$.) After the victory and the return to Paris, the directory of the Public Assistance was dissolved, and not even a rote of thanks was offered for this eminent service.

Brocal was not the man to trouble himself about compliments. He had done his duty and now all his energies were devoted to bringing forward his beloved science. He fonnded the Revue d'anthropologie the first number of which appeared in 1872 , and this journal he continued to edit as long as he lived. His next undertaking was to establish a School of Anthropology, and so irresistible were the ardor and persuasion he brought to bear that in May, 1875, the Dean of the Faculty assigned him the second story over the Musée Dupuytren for the new school. For the purpose of furnishing and starting it, the sum of thirty-five thonsand franes was subscribed by twenty-three members of the society. The work was commenced in July and completed in the following spring. The new school, however, was not to escape its share of opposition. The clerical party denounced the project without ceasing, branding its professors as atheists and materialists, and so thoroughly did they succeed in alarming the Minister of Public Instruction that that functionary was, with great difficulty, persnaded to authorize the school to proceed; when he, at last, did so, it was only for a year, and every difficulty and discouragement was thrown in the way. 


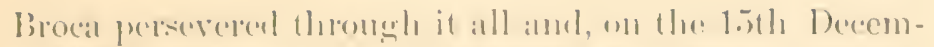
ber, 1sti, the selemel of Inthropology was opened hy him

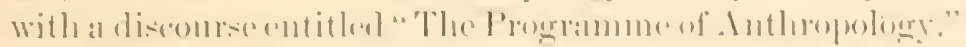

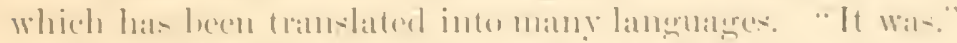

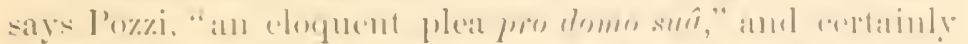
it was his own alifice, the selsool which he opered that day.

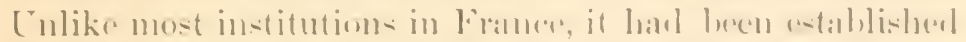

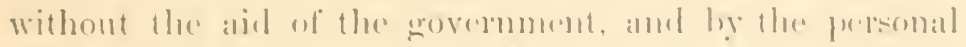

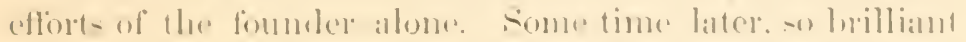

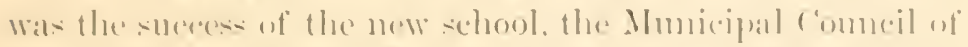

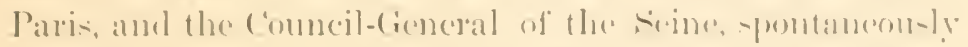

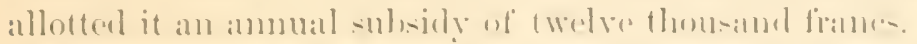

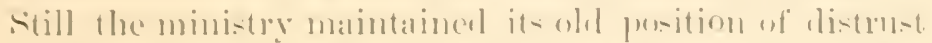

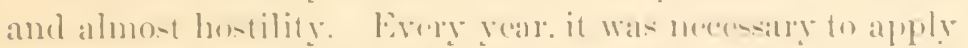
for at mew antlorization which it lepuirerl rencwerl efforte

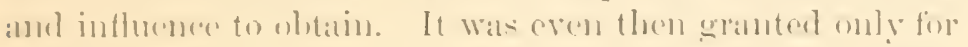

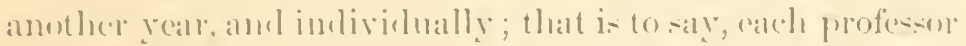

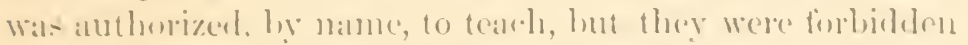

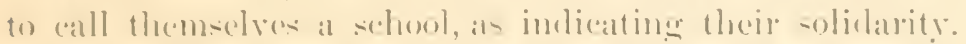
It length, the alection of listis ansolidated the repmblice

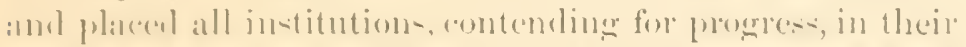

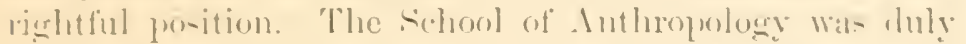

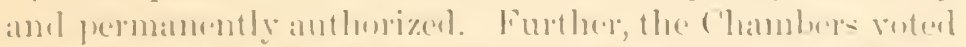
it all ammual subsily of twonty thum-and trance, which

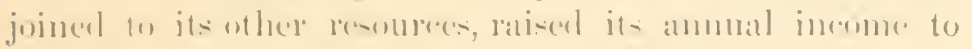

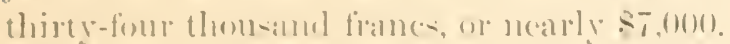

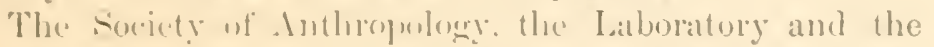
School, all moited in the same locality formed, thus, a ronferleration known as thr. Anthenpologrical [n-titute. The

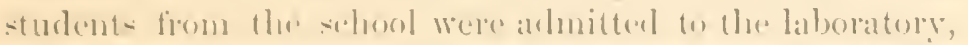

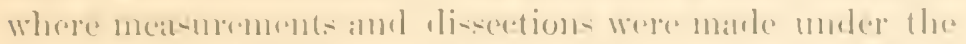

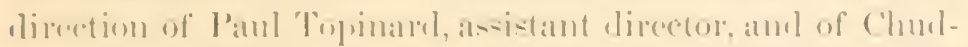

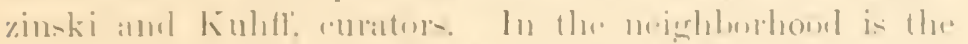
implortant library of the sorelety and the finet anthropo-

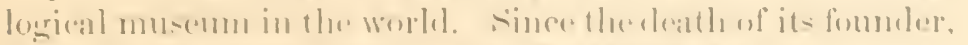
it has hem appropriately named Lat Mu-ied lirocal.

It may be imaterimel with what rati-faction Brosea wit-

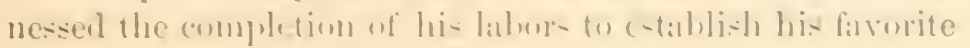


seience on a permanent basis. Of his own work in Anthropology, it is impossible, in the limits of a lecture, to give any adequate account. His friend, Professor Pozzi, has attempted a bibliography of lis writings which he admits to be imperfect, and which yet cover's seventeen pages, in double columns of small type of the Revue d'anthropologie, which is a large octavo in size. I have been able to add some few articles to Pozzi's list, and, of the whole, have made the following enumeration :

Broca's contributions to the medical sciences, embracing anatomy and physiology, both normal and pathological, and surgery, number 243 articles and volumes. His papers on the anatomy and functions of the brain are $5: 3$ in number. His last and most important work on this subject, a treatise on the morphology of the brain, was left unfinished.

In anthropology, I find 109 articles and rolumes upon comparative anatomy and general anthropology; 48 papers on general craniology, and 35 on special craniology; 27 papers on ethnology, and 19 on miscellaneous subjects. The total number of his printed articles and rolumes, so far as ascertained, is 53. . It is to be remembered that a large part of these papers are quite extensive, rumning through several numbers of the journals in which they aypeared. Many of them were reprinted in pamphlet form, and he, himself, commenced a collection of his anthropological memoirs, of which three large volumes were published. Among the more important of these contributions may be mentioned his paper on Linguistics and Anthropology; his General Instructions for Observations on Anthropology. This last was a coditication of the rules necessary to be observed by travelers and investigators: it was issued in 1865 , and was completed ten years later by the Instructions in Craniology and Craniometry. This very valuable and original work had immense success, and was translated into nearly every modern language. Of his writings on the hrain, the more important are his memoir upon cranio-cerebral topography; on the great limbic lobe; on the olfactory centres, and his admirable treatise on cer- 


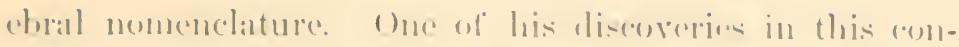

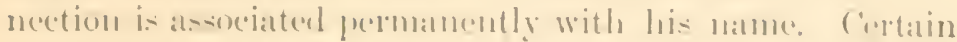

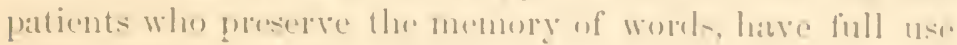

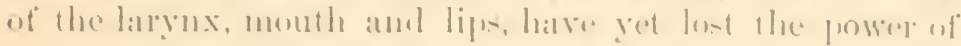

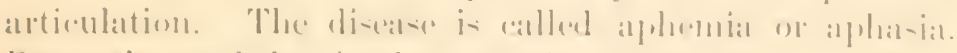
Brocal observed that in the antopsies of these pattenth- there

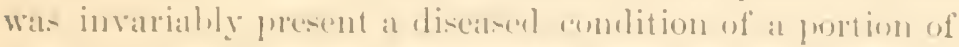
the thirel froutal convolution of the hatin wn the left -ide. This convolution, thus inferred to be the seat of language. is known as "the convolution of Brocas." In a val-t number of catses, the predietion hat heren makle, duringr life, that at eertain pertion of this anvolution, the - luffice of it - lowere thirel, would be fomml di-cised, and it hise lwon fultillerl

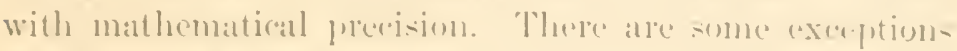

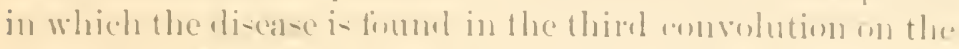

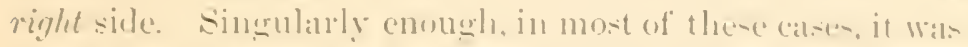

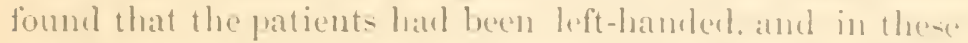
the riglit side of the brain is egemerally more dereloped than the left. The -ubject of the lonatization of the fumetions of the brain-by which we mean the discovering of the partic-

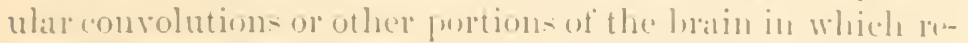
sille the functions of animal life-is of the highes interest;

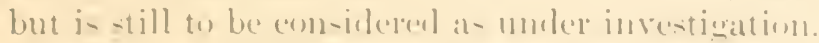

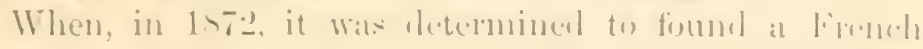
A--ociation for the Advancement of s. of the Euglish A-rociation, Brueat took all aletive pald in the

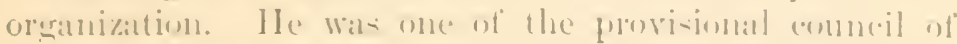

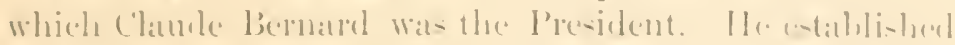

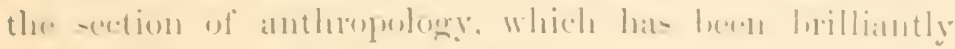

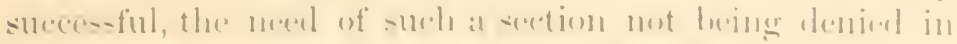

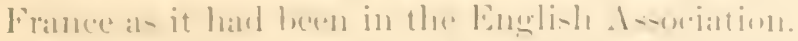

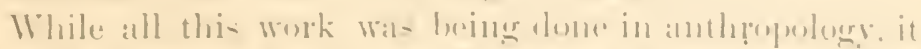

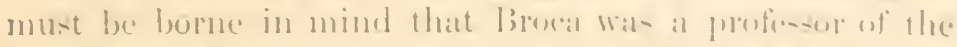

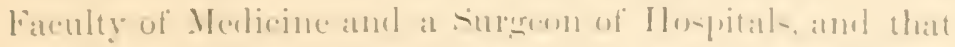

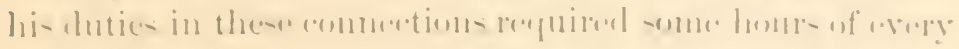

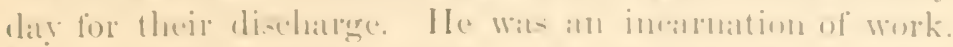
Natturally, the fuention arise- what wat the quality af this

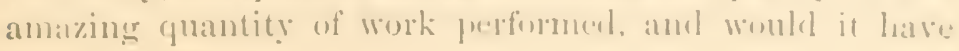


been better for his fame if he had concentrated his energies upon fewer subjects? In some persons, production is a slow process, accompanied with extreme tension of the brain; the thought dwells a long time in the mind before it assumes the form in which it is to appear; such persons bring forth in sorrow and in pain. 'This was not Broca's case. 'To express his thoughts with extreme rapidity, whether by speech or pen, was, to him, the most facile of functions. It seemed play rather than work. Ind yet, Trélat, a critical judge, said of lim, "Broca never wrote anything that came down to mediocrity." His mind was essentially many-sided, of restless activity and well sustained by the admirable physical organization which he possessed. His intense lore of truth and the ardor of his convictions, at times, led him to too great rehemence of expression. He was impatient with those who did not see the truth as he saw it, or dirl not see it as rapidly as he did. His work in anatomy, physiology, and surgery stands, to this day, mostly unquestioned. II is qualifications for anthropology are forcibly stater by one of his pupils, Professor Ball, who says: "Anthropology is a compound of so many other sciences that the intervention of a grasping and encyclopedic mind like Broca's is almost invaluable to form the connecting link between so many different branches of liuman knowledge. An excellent mathematician, a first-rate anatomist, a good Greek scholar, Broca combined in himself that diversified knowledge whiels the subject requires, with the synthetieal tendencies which condense these disseminated forces, and make them converge upon a single point."

In person, Broca was of the middle height and strongly built. His broad forehead and lustrous brown eyes gave a very noble expression to his face. In private life, his relations were in every way admirible. Benerolent and generous, he was adored by his family, and those who were once his friends were his friends for life,--he " grappled them to his soul with hooks of steel." He was a delightful conpanion in lis social hours. He lad traveled much, and would relate his adventures and observations with great 
humor. I maly be allowed to quote one incident which lie loved to recount.

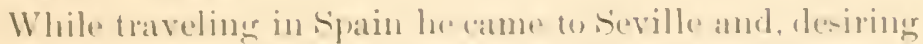
to be shaverl, sent for the nearest barber. Figatro alpeatred

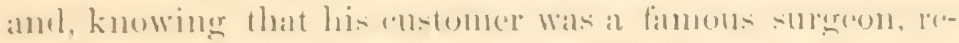

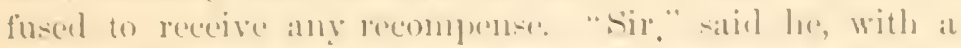

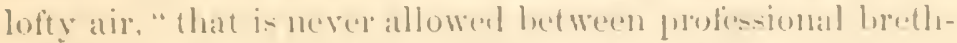
ren!" The chas of barber-surgeons exist- to-rany, in spalin, as: it did when cervantes wrote.

The erowning public homol of brocal's lite remanins to be told. In 1s7!), the senate nominated him ats permanent Senator, repre-cuting Science. Ile wals proposed, of course, by the left. The right, or monarchical, sile, marle ficree op-

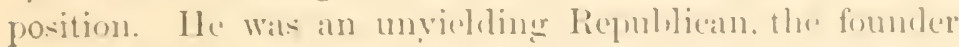
of the Anthropologieal Institute, which meant fresethinkiner and atheisu. 'They searched his writings for doctrines to eonvict him and. with great joy, publisher this quotation, "I would rather he an alpe hrought to perfention than a degenerate Adam." But this proverl to have been a saying of ('lipparde's aurl not of browis. I sentence was taken from his Programme of Anthropologry, "There is nu fith, however respectable, no interest, howerer legitimate, which must not accommorlate it-elf to the progres of human knowledge and bend hefore truth, if the truth be demonstrated." Even this searcely orthorlox doctrine, it seement. was cualified by the preceling sontenre which said that "sijence must keele aluof from anything not within its province."

Broca, with sharateristic independence, took no fart,

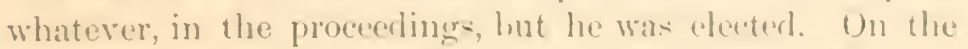
19th Fohruary, 1sso, a banguet was given him hy some of his mo-t attacherl frienste, members of the liaculty of Merlirine, of the Acallemy of Menlicine, of the soeicty of Anthropolngy, of the senate of the ('himber of Deputies cte.. in commemoration of the high homor hesowed upon him. It was the gramlest hamgunet evere griven to at seientitie matn. The luner table was filled with thooe who had hatrend his

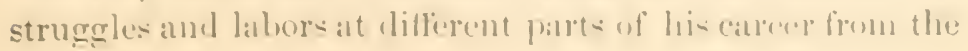


College of Sainte-Foix to the Senate. Professor Verneuil, his life-long friend, said to him, "If we are in great strength around thee, it is because thou hast continually made new friends, and hast never lost a single one."

In his speech of acknowledgment, Brocal said, "they would not have thought of me if they had not known with what certainty they could count upon my devotion to republican principles; and if, among many others not less trustworthy and more skilled in political knowledge, they have chosen a man of science, it is because they hold science in high consideration, and believe that to serve science is to serve one's country best."

His speech was one of the most eloquent he had ever delivered, and ended with a sentence that proved strangely pathetic, in the light of the after occurrence. He said, "were I superstitious, I should believe, from the great happiness I experience to-day, that some great danger was threatening me."

Five months later, these now sorrowing friends followed him to the grave. On Tuesday, the 6th July, 1850, he was in his seat at the Senate and was attacked suddenly by faintness. The next day, he had apparently recovered, and Thurselay evening was passed in work with his friend, pupil, colleague, and successor, Dr. Paul Topinard. Toward midnight, he was suddenly attacked with difficulty of breathing, he rose from his bed and, in ten minutes, he expired. The post mortem examination discovered no lesion of any organ,- - no cause for this sudden taking-off. "Cerebral exhaustion" was the medical periphrasis, which implied two things; - that the man had worked himself to death and that how he died was a mystery. He died at the comparatively early age of 56 , in the very plenitude of his powers and the height of his renown.

He was buried in the cemetery of the old church of the Celestins, in which his first labors in craniology had commenced thirty-three years before, and which led to his long course of studies in anthropology. The Vice-President of the Senate, M. Eugène Pelletan, in his oration at the grave, 


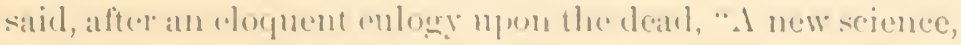
human palacomtology, las just originatme moler oms fect;

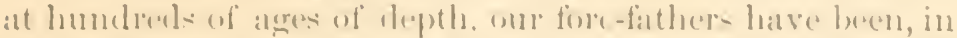
some wats, smprisel, lying pell-medl in the midst of the

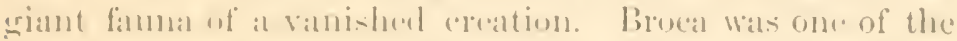
valiant piosme!s who fenctrated the foremost into the suls-

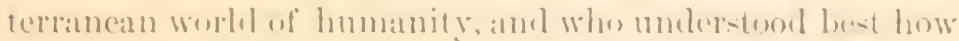
to thour light on =luch hi-tory as is loft of it."

Ilis work is eontinued hy those who welo his disciple

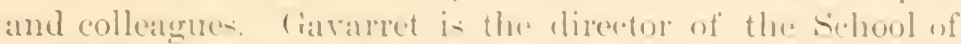
Anthrognelogy, Matthias Duval je director of the Laboratory.

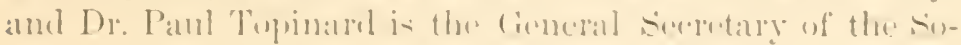

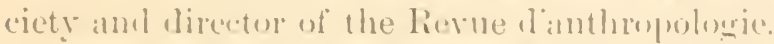

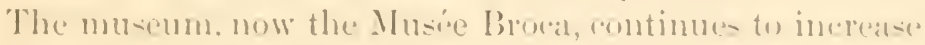

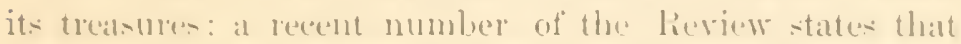

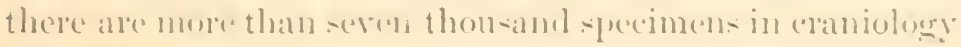
alone.

brocal left an enormoms quantity of notes and drawing-: also, two yluato volumes whir.h (rontain the mearemrennents of crania malle hy him durine twenty rears. The-c are dividerl into sixtr-four series of different races, and recorel more than 1 s.j, forol measirements.

Madame broca. hi- wirlow. has devoted a sum of money (1) foume a "Brocal prize"-le prix Broca. The subject uf compretition is " hmman and rompantativeanatomy in relation to anthropolong:" Mriter- of all nation- mal compete but

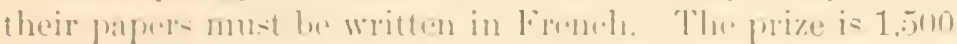

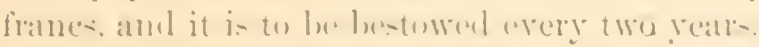

There in mot mucls mole that needs to be said of linoril

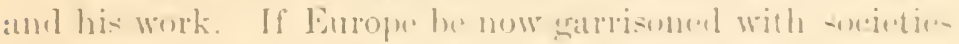

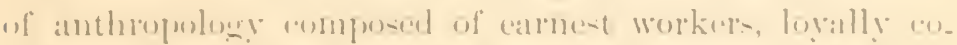

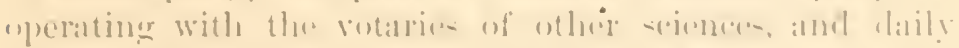

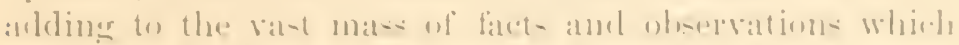

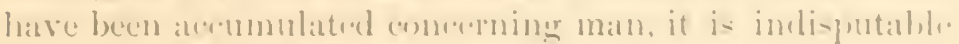

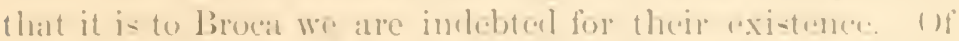
lis remarkable fitmes for the task which it liell to him to undertake, there (am be 100 lombt, but it was one predoninating quality of his moral natmm which gave him his 
great infuence over other men, and which has made his work so anthoritative and enduring, and that was his unswerving love of truth. In science, he was always the judge-never the advocate. Pure and lofty-minded, he stood aloof from intrigues, and honor's came to him unsought. The laureate's words may well be said of him,-

"Who never sold the truth to serve the hour."

In conclusion, allow me to remind you that there is what may be termerl a moral side of the science whose history we have been considering. To spend our hours in the study of man-to reflect upon his marvelons metamorphosic from the grimy savage of the cave to the gentleman of today-to ponder upon his curious devices, his laws, his marriage-customs, his battles, his religions, is to fill onr minds with a belief in a common brotherhood more convincingly than peace societies or missionaries can teach, and to lead us to repeat with 'Terence:- "I am a mantherefore all human things concern me."

** I desire to acknowledge my obligation to Prof. Pozzi's article in the Revue d'anthropologie for much of the details of the founding of the Institute- 


\section{NOTHE.}

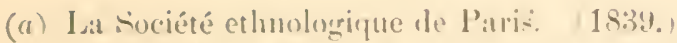

Publications:-Mémoires de la suciété ethnologinue. 2 vols., Siv. Paris, 1 St+1-5.

Bulletin de l.a sicieté ethnolugique de l'arin. Vol. I, Swo. Paris, Isti.

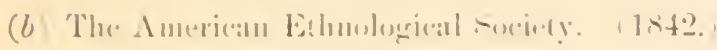

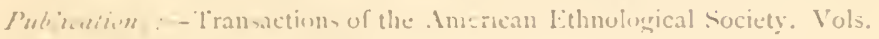
1, 2, Siv. X. Yorh. 1545: 1S4t.

Bulletin of the American lithnolonical sisciety. Sio. N. lork, IS60.

Ald: The Cimpel, wrimen in the Vero patuin of English, with Araloic

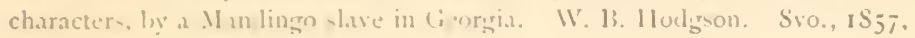
pp. 10.

Report on the Ithacals or ancient grasegark of Chiriqui. By J. K. Merrits. Sisu. 1seo. Pp. 14.

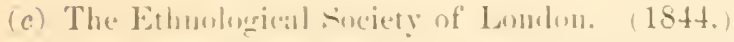

Pul'icuticns:- Journal of the lithnolonical Society, + vols., I $8+8-j 6$. Tran-actiom, etc., ; vol.,. 1\$59-6n. Journal, new serie-, 2 vols., r $\$ 69-71$. 13 vol... Sto., Lomilun, is $45-; 1$.

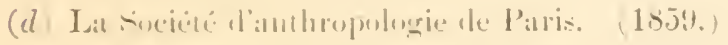

Pubicaron -liulletin, te la suciete d'anthropolugie de l'aris, Ist

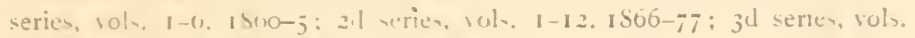

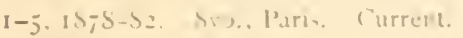

Ilemoire- de la tocièté d'anthropologite le l'ari- Ist series, vols. 1-3. 1S60 72: 211 erien, wolv. 1-2, 1975-\$2. Sro., Paris.

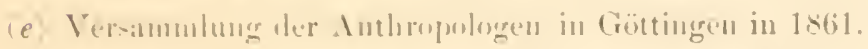

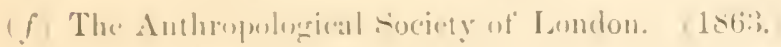

Publicintion :-The Anthropulogical keriew and Journal of the Anthropological sincrety of Lonton. s'volu., ISo3-1S;o. Juurnal of Ambropolngy. I wil., 1 >0-1. Siro.. I.ondon.

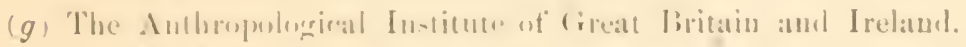
(1), 1 .

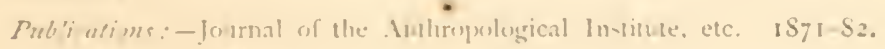
Svo.. Lonlon. Cirreint.

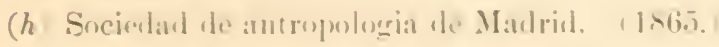

(i) Imper. Ob-hestro ljubiteli jestestwosnanya, antropologri i etnoyratii. Monoris: tisfi. 
(k) Berliner Gesellschatt für Anthropologie, Ethnologie und Urgesehichte. (1868.)

Publications:-Zeitschrift für Ethnologie. Organ der Berliner Gesellschaft, etc. Berlin, Sro., vols. I-I4, I869-ISS2. Current.

(l) Anthropologische Gesellschaft in IVien. (1870.)

Publications:-Nittheilungen der anthropologischen Gesellschaft in Wien. Wien, Svo., vols. I-12, I87I-S2. Current.

(m) Societit italiana di antropologia e li etnologia. (1871.)

Publications :-Archivio per l'antropologia e la etnologia. Organo della Società italiana, etc. Firenze, Svo., vols. I-9, 187I-79.

(n) The Anthropological Institute of New York. (1871.)

Publications:-The Jonrnal of the Anthropological Institute of New York. I871-2, 8vo., New York, Vol. I, No. I.

(o) Komisya antropologii Akademii Umiejetnoséi w Krakowie. (1877.)

Publications:-Zbiór wiadmości do antropologii Krajowéj wydawany Staranien komisyi antropologicznej Akademii Umiejetnosći w Firakowie. Vols: I-4, Svo., Kraków, IS77-So. Current.

(p) The Anthropological Society of Wasluington, D. C. (1879.)

Publications :-Abstract of Transactions of the Anthropological Society of Washington, D. C., for the Ist year, ending Jan. 20, ISSo, and for the $2 \mathrm{~d}$ year, ending Jan. IS, ISSI. Sro. Washington, D. C., IS8I.

(q) Deutsche Gesellsehaft für Anthropologie, Ethuologie und Urgeschichte. (187).)

Publications:-Correspondenzblatt der deutschen Gesellschaft, etc. Braunschweig, 4to, Vols. I-12, IS7I-S2. Appears (with separate pagination) in the: Archiv. für Anthropologie; Zeitschrift für Naturgeschichte und Urgeschichte des Menschen. Braunschweig, 4to., Vols, I-I4. IS66-S2.

** This society meets annually in some German city. The first meeting took place in Berlin in I 870.

(r) Congrès interuational d'anthropologie et d'archéologie préhistorique. (1865.)

Congrès I. Neufchatel, I S66. Compte rendu Svo. Paris, I866.

2. Paris, I867. Compte rendu. 8vo. Paris, I\$68.

3. Norwich, I868. Compte rendu. 8vo. London, 1869 .

4. Copenhagen, I 869 . Compte rendu. Svo. Copenhagen, I870.

5. Bologna, 187 I. Compte rendu. Svo. Iiologna, 1873.

6. Bruxelles, IS72. Compte rendu. Svo. Bruxelles, I873.

7. Stockholm, i874. Compte rendu. Svo. Chalons, 1875 .

s. Buda I'esth, IS76.

9. Lisbon, ISSO. 


\section{DEEP-SEA EXPLORATION.}

Iecture delivered in the Unifed siaten Nitioncl Ituenen, April 22, ISS2, hy l'ruf. WM. II. D.1L.

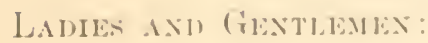

The subjert of this lecture maty be defined as avering the investigation of all that relates to the veean and its inhabi- tants, considered as a whule, with the exception wi tho-e features which alde due to the influenee of extermal ratuses, -mch as the tides, and thow whirh arre exhibiterl solely in shallow water, and there.ore atre in whe selrse whaldeteristic rather of the (a)asts themselves than wi the sea.

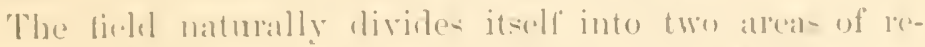
search, the physical and thr biological. The physical frat tures include the tempratuie of the seatwatel in dilledent

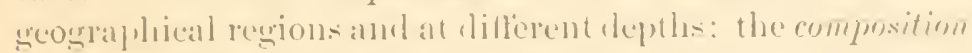
of the water and investigations into the ledative annonut - w

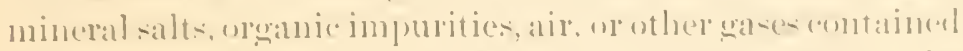
in it, and mpon which its weight or elensity depends: the motions wi the watre entalines in the herl of the necans, which, apart from the tieles, depend latrocly on its variations in temperatture and density, andel which, when tolorably antstant and -uffejently well narkenl to attrat the attention ut navigators, ale commonly known as acean enrents: and. lastly, of the degth of the seat of the topography and phetal leatures of the bed in which it is contained.

low hiolosical features incluele the rapture and classitirattion of the animal- living in the sea, e-periatly on its betton,

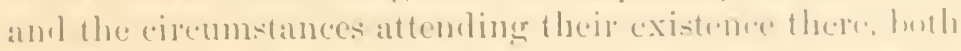
as reararels their food and mannel of living, and the rente-

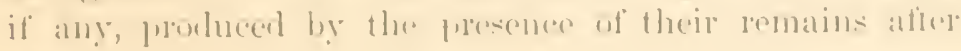
dealli.

It is evident that the field is tor latere 10 be trealled in letail within the limits of a single lecture, and therefore I

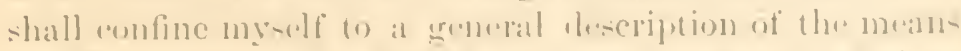
used in exploring the beel of the oreatl, of the eomelusions

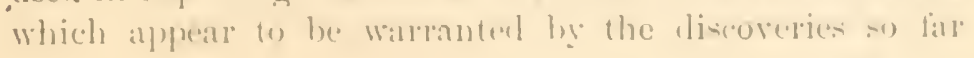


made, and a brief review of the history of such explorations and the part taken in them by our own country.

The determination of the depth of the sea, at least to a certain distance from the surface, is a necessary preliminary to navigation, and hence has grown with commerce from the time when the primitive sarage first launched his rude canoe in the Nile delta until the project of an Atlantic cable rendered it necessary to plumb the depths of ocean. The use of a weighted line for this purpose probably long antedates the historic period. The ordinary mariner's leadline is familiar to nearly everybody, and ronsists simply of an elongated picee of lead with a slight indentation in its hottom, and a hole in its smaller end by which is attached a stout cord, large enough not to cut the hands when being hauled in, marked at regular intervals with tufts of red, white, and blue flamnel, or small leather tags, to indicate the length of line l'un out. In the cavity in the bottom of the lead is usually placed a little tallow or hard soap, which will bring up a few particles serving to indicate the kind of mud, sand, or gravel, of which the botiom is composed. In ordinary depths the line runs out rapidly until the bottom is reached, and the thump of the lead on hard sand is distinguishable in still water at a depth of nearly a quarter of a mile.

But in greater depths and in waters, or from a ressel, more or less in motion, the accuracy of the soundings possible by the common method becomes rapidly less, and at depths of 1,000 fathoms (about a mile) the determination becomes quite untrustworthy.

This was not at first realized by inrestigators, and more or less confidence was placed in depths, such as those reported by Walsh, Denham, and Parker, who ran out from six to ten miles of line, in the Atlantic without recognizing that the bottom had been reached, in regions where we now know the depth does not vary much from two miles. The mystcry and uncertainty which thus became associated with the conception of the depths of ocean had, as will be shown hereafter, an important effect in retarding attempts at exploration of the deep sea. 


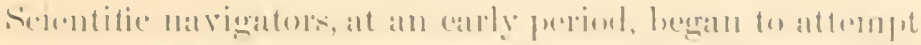

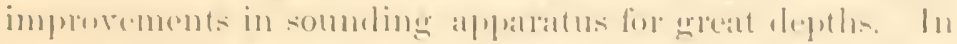

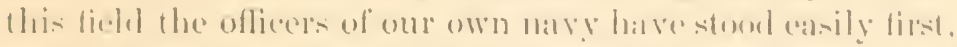
not nuly in oreler af prority of invention, hut also in the perfection of the results attained up to the present time.

An arly improvennent was the sulstimlim, in plater af the ordinary leat-line, of a very fine line and a very leasy weight. Which ran out rapidly, and was not intemlen lo lue

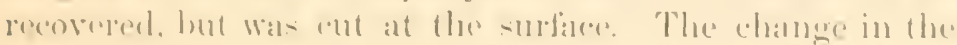

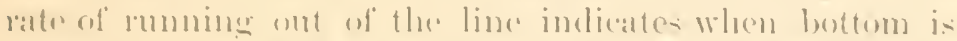

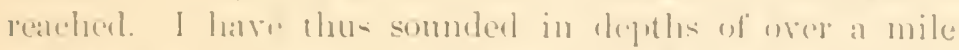
with sttistatory restls. bitt the nature, as woll as the listance of the bottom, is an impurtant feature in smell investi-

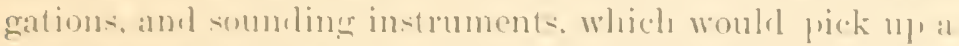
good-sized simmple of the bottom at the alepth of a mile or more, and bring it safely to the surfice. were the next in orler of invention. Sil Joln Ross, an arly as 1s1s, invenferl : " clamm" something like an old fis shioned pair of sugar tomgs. which should be chosed by a lilling weight on striking the lottom. The same idlat. in difterent forms, las since been trienl hs screral inventors. hut it lats never provenl satisfactury in the long rum. I piece of gravel or shell gret - hetween the edges of the tongrs, huld them apart,

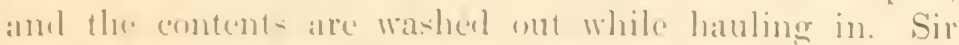

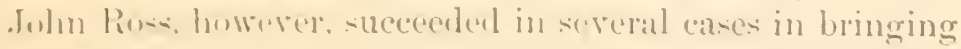

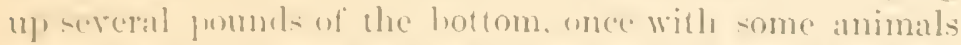
combaned in it. foum depth-of orer five hmmelreel and possibly one thomsand fathoms. Morlifirations of this princi-

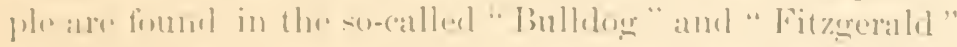
someling in-truments, lonth of which have luesu well -poken

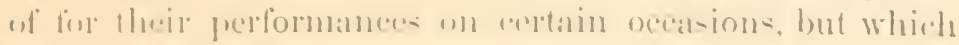

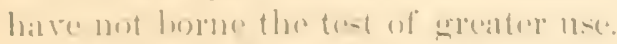

The fir-e important alvanese in this direcetion was made

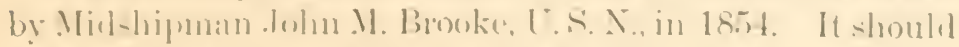
bx-tatenl that in aldition to the dillieulty of exotting the weight and line perpendicularly to the lottom, and knowing when tho hottom has been reacherl, another important featume in sombliner work is the reserery of the line and 
lead. When sounding is done with hempen-line, and a sounding weight of fifty or one hundred pounds, it will be apparent that the friction of two or three miles of line, with its tags and instruments attached, must be enormous, even if it could be hauled up perpendicularly in still water. But when the vessel, as she always must, drifts a little, and the line comes up in a diagonal direction, the friction, adder to the weight, renders the safe recovery of the line, soundingcup, and thermometers or water bottles attached to it-a matter of great difficulty, some uncertainty, and several hours of time. In anything but the best of weather such work becomes almost impracticable.

Mr. Brooke's invention included an ingenious and simple apparatus for detaching the weight at the bottom of the sea, and leaving it there. Having thus to haul up only the line and the light tube containing the sample of the bottom, the labor was greatly diminished, and the time of hauling in much shortened. Brooke's apparatus has formed the basis of the only really successful sounding-eups which are now in use either by our own or foreign navigators. Improvements on the original form were successively made by Capt. Shortland, of the British navy, Capt. Belknap, of our own navy, and lastly by Lieut. Com. Sigsbee, U. S. N., while engaged in the service of the Coast Survey. The instrument, as perfected by Belknap and Sigsbee, does not seem capable of much further improvement, and works to a charm. The accessory machinery for use in deep-sea soundings, such ats small engines, reels for the line, blocks, and elastic arrangements of rubber or steel springs to guard against the effect of sudden jerks upon the line, have been improved from time to time, and are fully described in publications on the subject by Sir Wyville Thomson and Lieut. Com. Sigsbee. The most important improvement of recent date is due to the distinguished Professor Sir William Thomson, of Glasgow, in 1872. This eonsists partly in the employment of fine steel piano-wire for the line instead of rope, and partly in the method of its use. Instead of the tags on the line to determine the length run out, the latter is known 


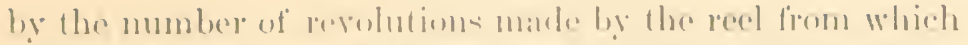
it mucoils, thus saving a valst anmonnt of firetion letwern the water and the wire-line. 'The momont of tombling lnt-

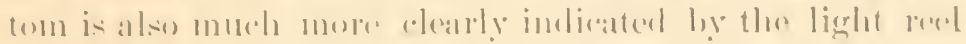
(mployed. whireh, as-isted hy the ahsenese of fiction on the

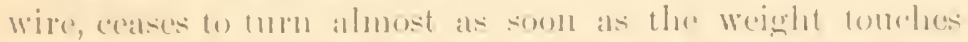
bottem. It is imposible, in the hedef aceomet I can give you, to go into the minuter details which may lor foumd in the publieations puremsing mentioned.

This invention las provent to be of the greatest importance. anul, singulary rmough, lhomgh invented before the celobrater rosige of the C'hallenger, sest out ly the British government, and immerliatoly taken up by balknal in our own sommling apeditions in the Sorth l'alcilic, where its value was themonghly dromonstrated, the asuntrymen of

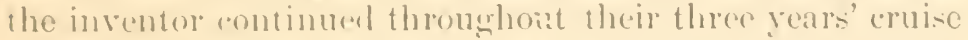

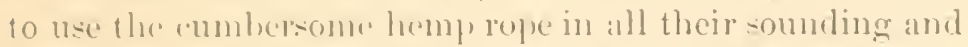
Iredging work. therely diminishing the cfloctiveness of their operations by at loat sixty per eent.

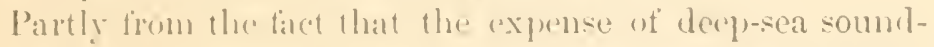
ing appelitions is - se weat as to place them beyond the means of provale individuals or scientifie societies, and partly from the musatisfactory results and onomoms leptles

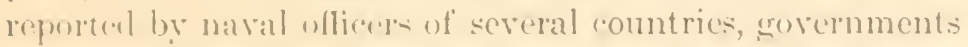
and scientific lodies remalinerl. mutil rerent years, indiflerent or sceptical at to the practicalbility of making researches in the deep-sea whieh should prorlure results at all alequate to the expense insolverl.

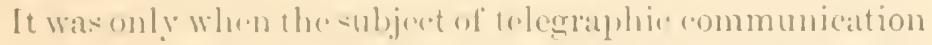
by cahle moler the sea assumed a commeredal importance which could no longrel be innored, that a knowledge of the comelitions of the sea bottom, especially in the North Atlantice, herame a necesity. Heepresal exploration may therefore be silid to latre eommenred systematically only

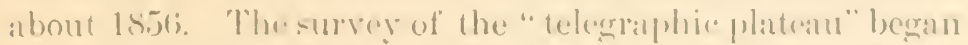
about this time by the aid of the British amel American navy, and eren with the comparatively imperteed meanlhen avalable, a vory larese amomut of information wal

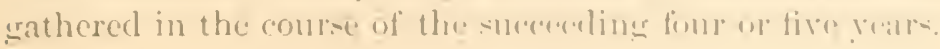


I have already spoken of the attempts at securing specimens of the bottom which accompanied sounding by various methods. It is evident that the amount of material which can be obtained by even the best modern somding apparatus is too small to give any adequate irlea of plants or animals which might exist on the sea bottom. This follows both because only the smallest animals could find entrance into the tubes intended to bring up specimens of bottom, and also because the apparatus is not fitted nor intended for the purpose of eapturing living animals, and if any existed on the spot struck by the lead the blow would probably reduce them to fragments.

Other means are then necessary for this purpose, and since deep-sea explorations have lately included both dredging and sounding as well as temperature observations and collection of water-samples, I shall proceed to describe the various instruments used for these purposes before considering the work accomplished by them.

The dredge and trawl are instruments which have been used fiom time immemorial by fishermen, and which, in a modified form, are employed in the deep sea for the capture of its inhabitants. The naturalist's dredge was designed in nearly its present form by (). F. Miiller, of Denmark, a very distinguished early naturalist, more than a century ago. It has been made more conrenient and effective. but the morlifications are rery slight. The best form seems to be that adopted thirty years ago by I)r. Stimpson, and used by American naturalist ever since. It comprises a frame of heary iron forming a parallelogram, the two long sides beveled outward to act as scrapers; it is perforated along the hinder edge with a row of small holes, into which a net and two flaps of canvas are laced with copper wire. The canvas is outside of the net and longer than the latter, and protects it from being cut by sharp stones on the bottom as it drags lialf full of mud behind the frame. Two movable arms project forward from holes in the short sides of the iron frame, coming together about two feet in front of it, to one of which the dredge-rope is attached; but the other is 
only lashere to the tir-t with park threat. Thu-, in dran-

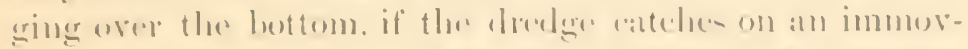
able rock, the train heaks tho park thrate, the two arms

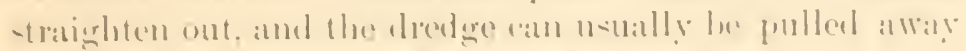

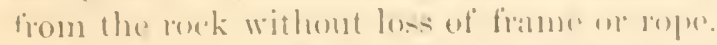

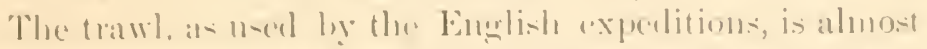

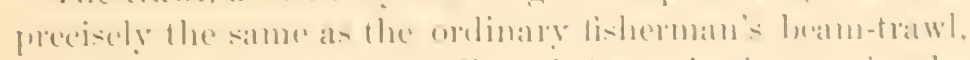
in which the material is collecterl from the lestom by the

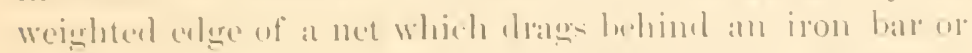

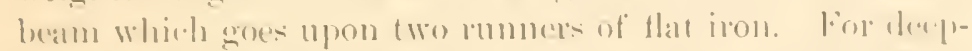

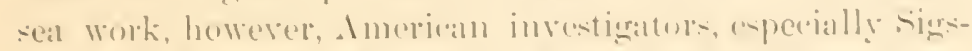

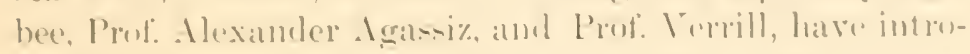
Anesel important modifieations, not only of the trant, hut of

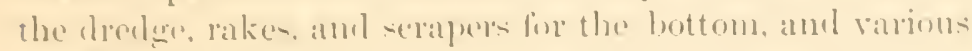

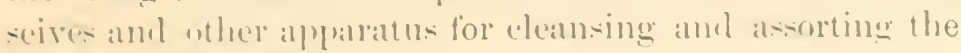
malcrial collected.

I rey impurtant andition w the means of collecting in

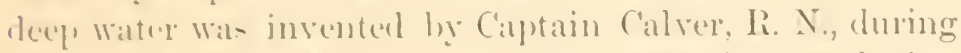
the vorage of the loremine. This consisted in employing

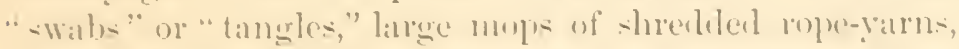

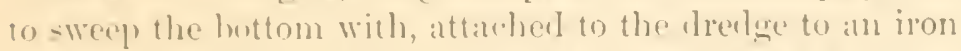

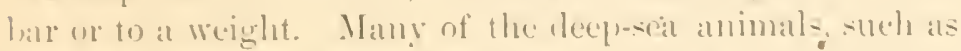

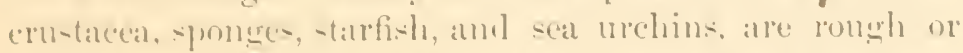
privklyand the long mops of wot thesuls entangled thom

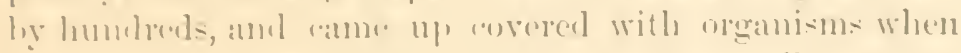

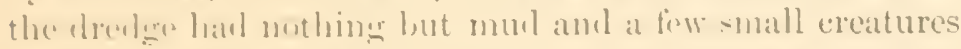
in it. I rery latre proportion of the animals collecterl from the - at lestem has leen olstained hy the wie of these fameras or - Wabs, thomgh many of the animals come mp in a mat-lienl al lirukin-tate.

Tushtain simples of watre finm any depth, without anmixtme of other water, lerass eylinelers with peppet valves

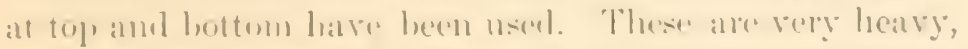

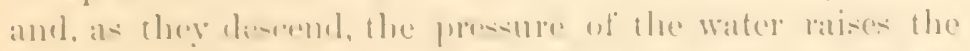

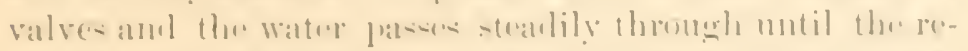

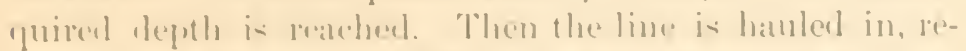

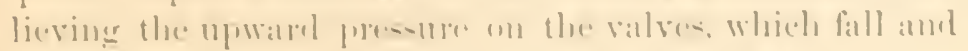

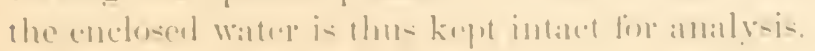


Several devices more complicated than the ordinary "water bottle" have been employed for the same purpose with success, especially one invented by Captain Wille, of the Norwegian navy, and the Sigsbee water-cup, but all embody essentially the same prineiple.

Most of you have seen thermometer's which register the greatest rise or fall of the fluid in their tubes by means of a little enclosed index like a double-headed pin, and which are known as self-registering. Such an apparatus is evidently neecsiry to obtain a knowledge of the temperatures of the deep sea, since no one can read the thermometers when submerged, and the height of the column when hauled in will necessarily represent only the latest temperature near the surface.

All attempts to use ordinary self-registering thermometers in deep-sea work failed as soon as tried; not only because the immense pressure of the seat water at great depths compressed the bulb of the thermometer, thus forcing the fluid in the tube to a point far above that which would register the actual temperature, but because the pressure was usually sufficient to crush the bulb and tube into fragments at a comparatively moderate depth. At 2,500 fathoms, which is the arerage depth of the ocean, the pressure is over three tons to the square inch, which is far beyond the endurance of any ordinary thermometer bulb. To ovcreome this difficulty, sometimes the entire thermoneter and sometimes the bulb of the thermometer has been surrounded by a second bulb nearly filled with alcohol, so that the outer bulb was supported by the fluid and the air bubble by yielding to compression would relieve the interior bull from its evil effects. This method has proved completely successful and the thermometers now in use for deep-sea work are entirely of this description. Those with an exposed stem and double bulb are preferred as responding more readily to the temperature, though subject to a slight correction for pressure from which the totally enclosed instrument is free.

Sir John Ross, on his remarkable voyage in 1S1S, was supplied with thermoneter's of this sort, and took the first 
deep-sea temperatures. But the instrument siems to have been forgotten eren in Eingland, find, in the suberpuent

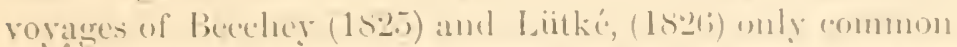
thermometers were sinplied, and the deviee sermis (1) have beren independently re-invented by Glatisher, Ningetti, and Miller, within the last twenty years. As the thermometers most commonly used for this purpuse are marle by the firm

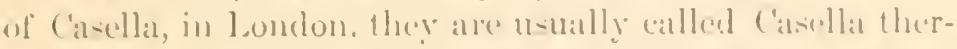
mometers: Negretti and Zanbra, of London, hatre invented another form of thermometer less envenient in size and shape than the (aredla, but which ofters a meritorions advance in some other direetions.

Metallic thermometers, registering temperatures by the mequal contraction and expansion of diflerent metali combined in one instrument, have been invented, and, while perfert in theory, have not been found satisfuctory, except in moderate depths, when put to actual test.

Inving describerl the varions instruments amployed, it remains to inclieate loriefly the manner in which they are used, premising that, for the minute letails of operations of some complexity, it will be necessary for thone interested to refer to special treatises on the subject.

For good work in greatt lepths of watter at stam ver-ed is absolutely neesesary. It is important that the lead line, whether of rofe or not, shonde desent perpendicularly, ats otherwise the length of line rum out does not indiente the true depth of the water, and enreater strain on the line is involvent in hauling in. Now at sea there is alwaly some watre motion or swell, wern in the ealmest weather, atmel un-

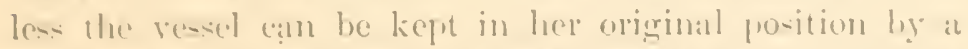
sentle use of the jropelling matehine drift away from the y pot at which the leat wam hoppled into the water. In rumbing lines of sommlingrs the now of -tem is also necessary to contime on the desired antr-e irre-prective of the winds. The distane letwern any lwa statome, not tixed by astromomical abecrvation or hearings on land,

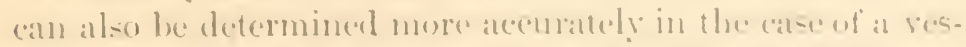

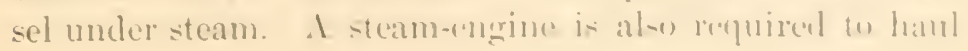


in the line, which in dredging would otherwise require the labor of many seamen.

The operation of sounding is sufficiently simple, and requires no explanation. A thermometer is usually attacherl to the line at a short distance above the lead or somming cup. If serial temperatures are desirer several thermometers ma be attucherl to different parts of the line, or several water bottles if water samples are required.

In dredging or trawling the dredge or trawl is lowered to the bottom by a line of sufficient strength. This, in the work of the Coast Survey, is of wire rope, as suggested by Prof. Alex. Agassiz, which, as compared with the rope nsed on the Challenger expedition, saves much friction, much room in stowing on the ressel, and easier handling, with no loss of strength, and a great gain in the time ocenpied in reaching the bottom and hauling in. In order that the motion of the vessel in drawing the dredge over the bottom may not tend to raise its mouth off the bottom, a weight is usually attached to the line at some distance in advance of the dredge and some slack line is run out, the resulting position of the ship, weight, and dredge being shown on the diagram exhibiter.

On the 1st of September, 181S, Sir John Ross, R. N., ran out 1,000 fathoms of line, and in the mud, brought up by the somnding-cup, were tubicolous worns, while at 800 fathoms was entangled a fine brittle star-fish, sometimes known as a "Medusa's Hearl" on account of its many arms. This shows that the actual depth conld not have exceeded 800 fathoms (since star-fish do not swim, ) and was probably less, but it is the first recorded instance of the capture of animals from any such deptl.

In 1847, Sir James Clarke Ross, R. X., published an account of his antarctic voyage, in which he states that several shell-fish were brought up from 1,000 fathoms on that expedition, and that he believes the bed of the ocean to be teoming with animal life.

In spite of such testimony the existence of life on the sea bottom, at a depth beyond two or three hundred fathoms, 
was generally doubted or lenied up to a enmparatively recent time.

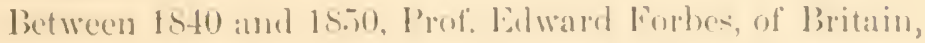

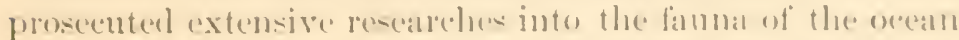

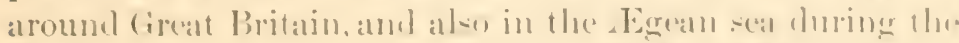

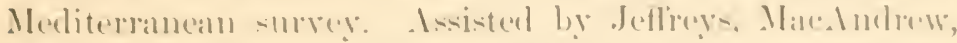

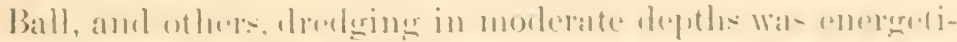

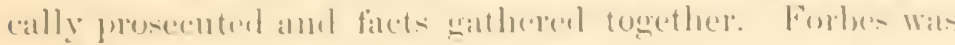
the tirst to philowplobally treat these puestions, alld wals a

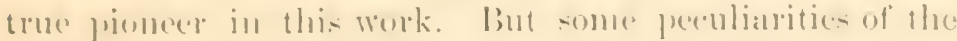

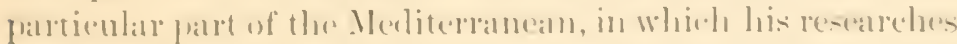

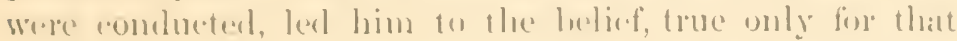
localits, that anjual life dies ont in the regrom hetween two humbled and three humberel filthoms in depth, and that at zero of life is reatuluel alsout the latter point.

The premature death of Forlues hromght to an motimely end thuse studien which would have douldten morlified hisview- while the weight of his mpinion, and the geculiall

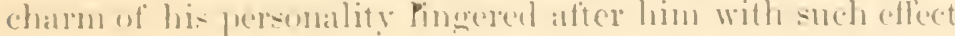

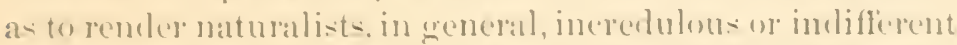
to evilence which gradually alceumulated to show that he Wits in crrort.

In 1stri, Ammiral spratt, R. N., drederel in :310 fathoms several sledl-fish, in the vicinity of Malta.

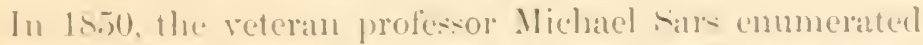

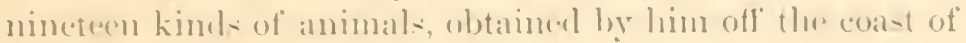
Norwat, in more tham :3()(1) fathoms.

In lis(io, Dr. Ci. C: Mallich, maturalist to a Britislı souml-

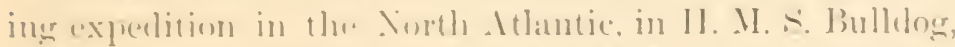

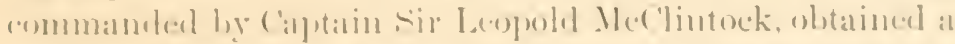

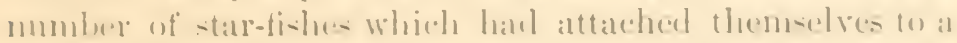

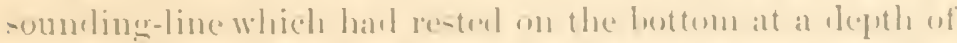

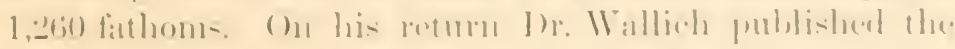

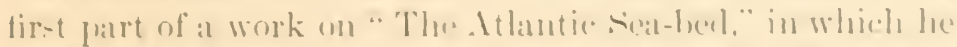

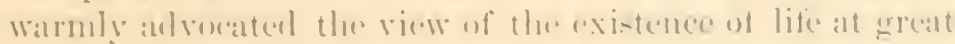

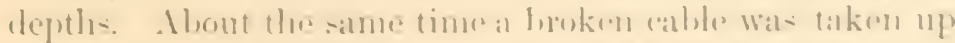

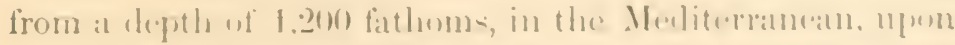

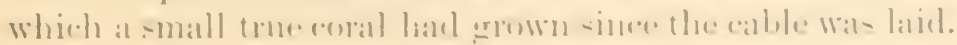


This was discussed by Mihne-Edwards, the distinguished French naturalist. Neanwhile the energetic Scandinavian naturalists were pushing their researches into the deeper water along the Norwegian coast.

Still these facts failed to secure that general consideration which was necessary, in order that they should have their appropriate effect on scientific opinion. Individual naturalists, it is true, were more or less impressed; the views of Forbes were occasionally called in question, but it was reserved for American naturalists and hydrographers to initiate that series of researches which has revolutionized scientific opinion, remodelled our views of the physical conditions of the deep sea, and culminated in the most remarkable and fruitful scientific expeditions of any age.

In May, 1867, under instructions from the Superintendent of the Coast Survey, Assistants Henry Mitchell and L. F. de Pourtalès explored the narrow part of the Gulf stream between the northwest end of Cuba and the American coast. Dredgings were undertaken in depths extending nearly to five hundred fathoms, and representatives of all branches of the animal kingdom below the fishes were brought up. The work was interrupted by an outbreak of yellow-fever on board, but the main facts were sufficiently verified, and their important bearings fully set forth in the report of Tourtalès. The depths from which these animals were obtained were not greater than those from which Sars had obtained living organisms on the Norwegian coast, but those collected by Sars were mostly animals common to the adjacent shore, or which might be expected to be found in shallow water by fuller search. But the Gulf-stream dredgings revealed an entirely new and beautiful series of forms, many of them like nothing which had previously been known to naturalists-corals, sponges, crinoids, starfish, echini, shells, worms, crustaceans-all offered new and elegant representatives which attracted the attention of specialists in every branch of marine zoölogy. In the following year six lines of dredgings were run by the Coast Survey observers across the Gulf stream, from the Florida reefs to the deep sea be- 
yond the streame. Nearly one humbled hamls of the drealge

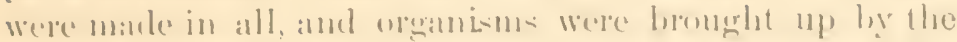

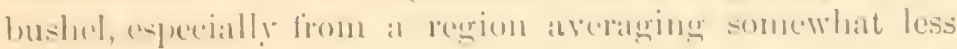
lhan there humblent fitthoms, hut also to some extent from

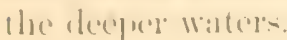

The work of lstic. however momportant in the aretual bulk of the eollections mate and the depth reached, when

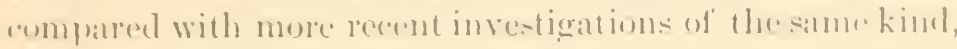

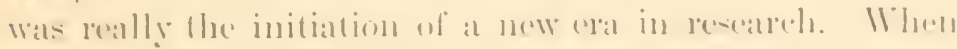

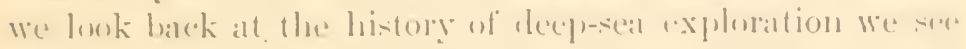

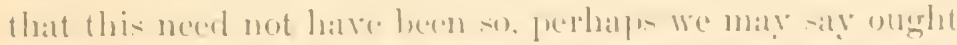

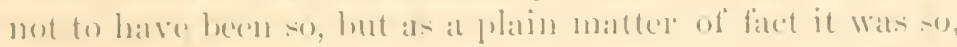

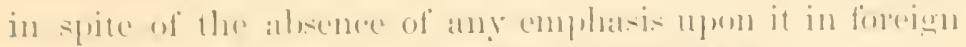

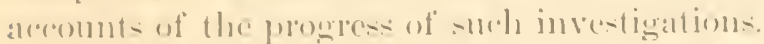

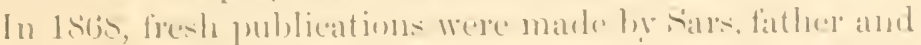

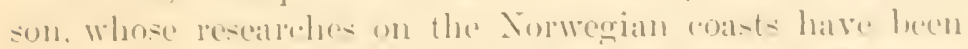

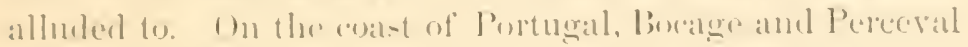

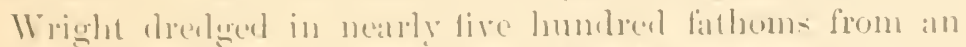
open boat, obtaining the romarkable "ghtass sponge," IIy-

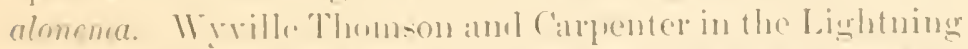

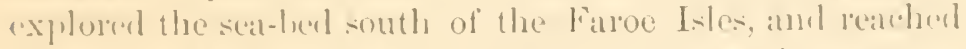

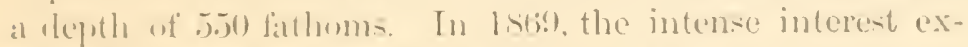
rited by these disenterite led to the royages of the British

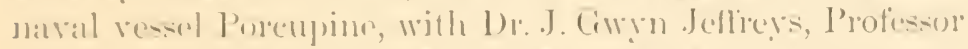

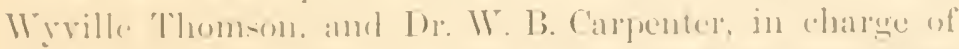

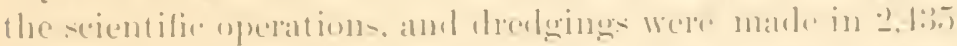

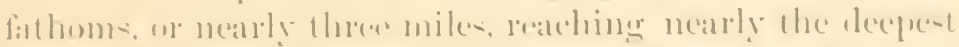

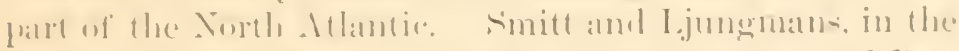

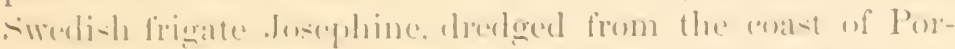

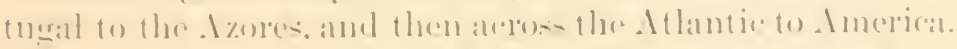

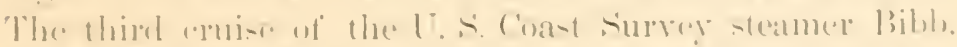

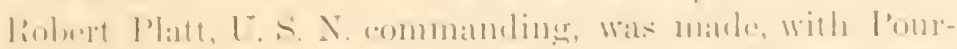

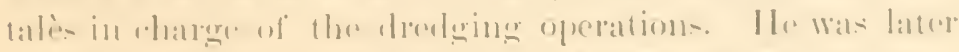

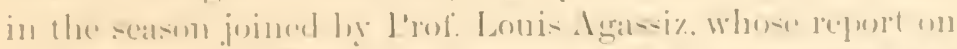

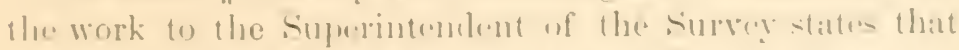

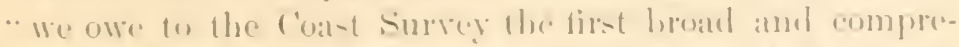
hem-ive batsis for an explubation of the sea luttom and

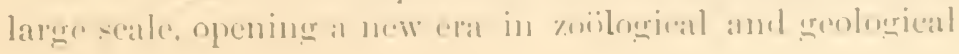


research." [n 1870 , the Porcupine was again sent out by the British Government, and, under the supervision of Jeffreys and Carpenter, work was done between Britain and Gibraltar, and thence into the Mediterranean.

In 1871 the Coast Survey launched a new steamer, the Blake, especially adapted for hydrographic work in the deep sea, which, muler the command of Lieut. Commander Howell, at once began work in the Gulf of Mexico. Another steamer, the Hassler, for work on the Pacific coast, was prepared, and sailed for California via Cape Horn with Prof. Agassiz, Pourtales, Dr. Thos. Hill, Dr. Franz Steindachner, and others, as a scientific corps. Much natural history work was done, but deep-sea work was rendered impracticable by unforceen circumstances after the royage began. In 1872 the voyage of the Challenger, now of world-wide celebrity, was begun under the scientific supervision of Sir Wyville Thomson and the naval superintendence of Capt. Sir G. Nares, R. N. This voyage extended to both oceans; soundings were made to 4,475 fathoms, dredgings to 3,875 fathoms, and the trawl was used in over 3,000 fathoms. This expedition oceupied three years and five months, and the scientific results are being publisher by the British Govermment in a magnificent series of quarto volumes. During the year 1872 the Coast Survey continued its systematic development of the hydrography of the Gulf of Mexico and the adjacent sea, the dredgings being taken under the supervision of Dr. IV. Stiminson. They formed the last scientific work of that lamented naturalist, whose dredgings and investigation of the marine fauna of the Eastern United States hal extender orer twenty years.

The deep water work of the United States Fish Commission, organized during the preceding year, began this season, and has steadily grown in importance and extent from year to year, under the direction of Prof. S. F. Baird and the immediate supervinion of Prof. A. E. Verrill.

In 1873 Capt. Geo. E. Belknap, U. S. N., undertook his now celebrated sounding (ruise across the North Pacific, in the U. S.S. Tuscarora. To dredging was done, though sev- 
oral animals were bought up by the somding-(-up), but the expeclition is memomalole as having been the oceasion of the first proctical nee of wire in somenting, for the important

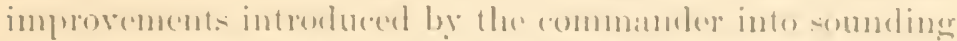
instruments and methods and for the great deptles obtained

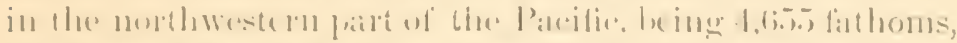

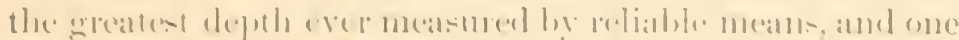

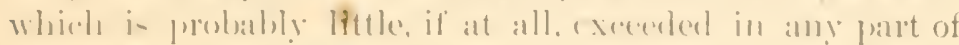

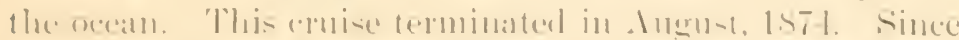

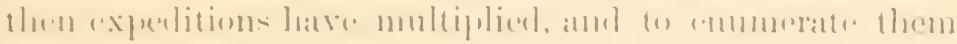

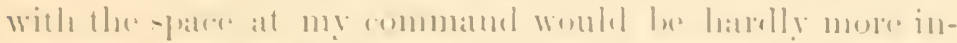

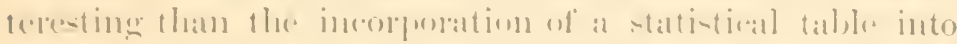

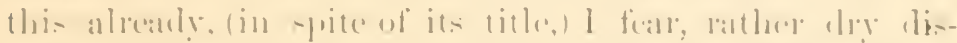

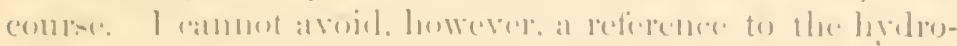

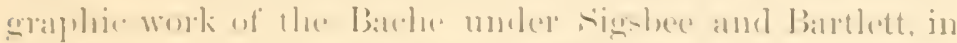

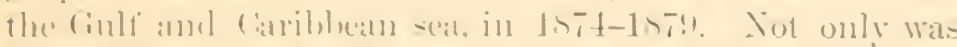

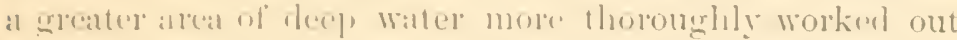

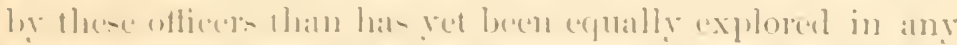

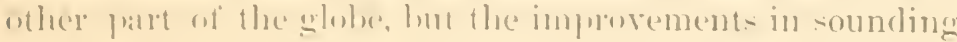

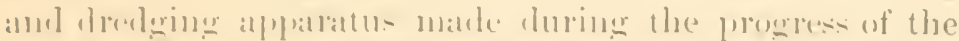
werk have almo-t revolutionized such investigations. There

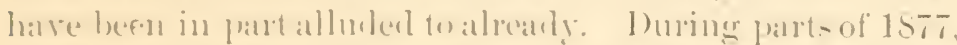

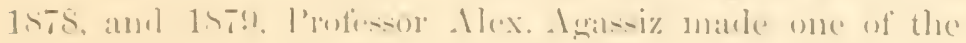

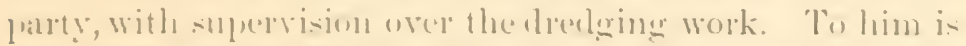
dure, amone many other sletail-, the substitution of wire-

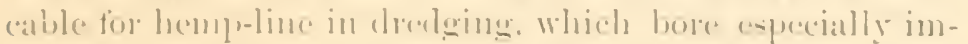
fortant frut: and by him the mo-t injortant scientific

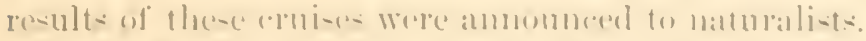

The historic part of thi- lecture mu-t alone with a mele

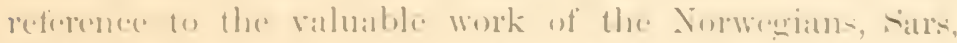

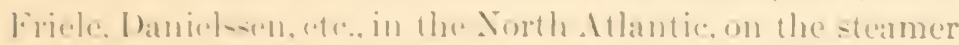

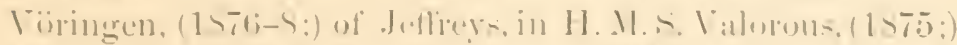

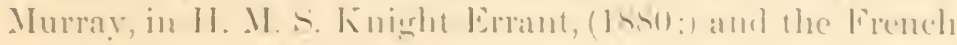

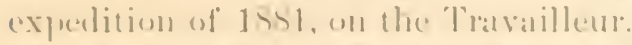

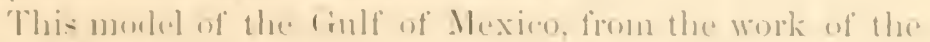

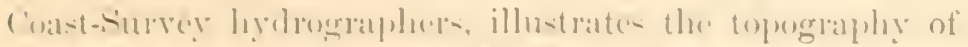
that part of the sea luttom. You will observe the singular platean which extemel-alunt the peninsulat of Yureatan and 
west from Florida. Fornerly it was suposed that the peninsula of Florida was due to alluvium from the rivers of the Mlississippi valley and other sonrces settling against a harrier of coral reefs which grew toward the south and west, as their northem portions were smothered by sediment. This shows, however, that the coral reefs have simply availed themselves of the advantages presented by the steep edge of the above-mentioned plateau so abuntantly supplied with food for them by ocean currents; and that, in its main features, Florida was outlined by different and far older agencies than the now existing coral reef's. The same is evidently true of Yucatan.

To another point I would call your attention as of economic interest. We know that by most engineers it is believed that experience has proved that channel-making by the jetty process is a mere temporary alleviation of bars and other obstructions to commerce. The permanent success of the Eads' jetties is even now a matter of doubt, and there is no doubt that in time extensions will be called for. But it will be observed that at no other point on the Gulf coast of the United States is the 100 fathom line so near the actual coast as here, and the inference is, perhaps, not too far fetcherl that, therefore, not only is it probable that with certain extensions of the jetties (other circumstances permitting) a point will eventually be reached where the slope seaward is so steep that a bar can hardly form or be maintained, but also that at no other point on the whole Gulf coast could the jetty system lave been applied to the improvement of a river mouth with any reasonable prospect of maintaining a permanent channel.

It may also be observed, from an examination of this model, what we should find confirmed by an equally thorough survey of the ocean at large, (as we know from recent examinations of the Atlantic sea-bed,) namely, that while the sea-bed, like the dry land, has its irregularities, they differ in character from the irregularities of the dry land. It is true that sharp peaks and elevated rocky areas have been discovered in both the Atlantic and Pacific, though none 
appear in the rifit of Mexico. But, exilusive of thene, which probably project from a comparativoly ren slope, the topography of the seathed in aleep watter is anred in

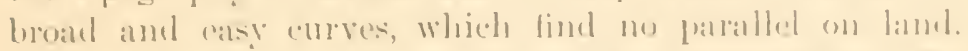

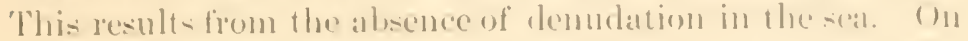

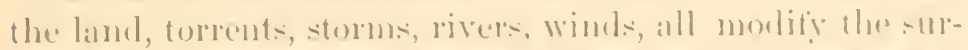
fares, which must have originally heen moch like that of

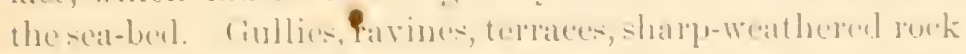

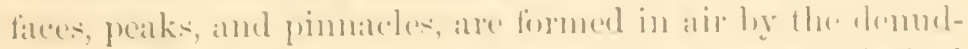

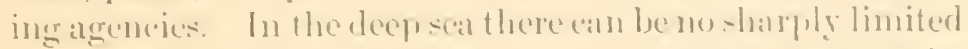

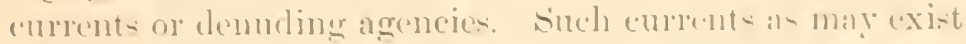
will have ill-eletined marerins, will move at slow rattes and

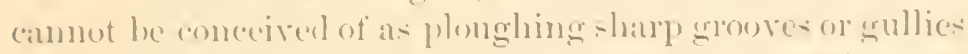

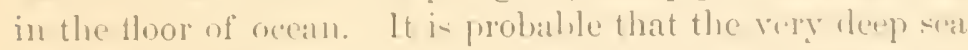
is for the most part a renion of profomel quiet, where the

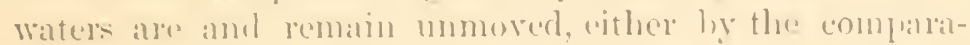
tively superticial ocean currents and tirles or the pulses of the waves as they heat on distant shores. The great deeps which you sere representer on this momel and in the chant of the Atlantic sea-bed here exhibited are not paralleled hy anything on lyy land, exeept the basins of the freat Lakes. Were they above the seat they would beenme lakk

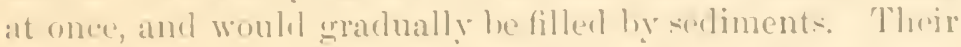

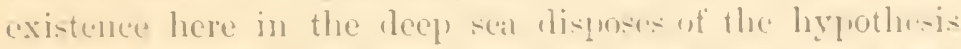
rashly alvanded hy some graclalists. that great lake basinare due only to the action of glaciogs and that without the previous existence of land-iee there would be no large lates on the earth's surfaee. It would be a bold man who would propere to locate glaciers on the Lettom of the ciulf of Thexien.

The eirculation of the waters in the sea has been theroretically areounted for hy diflerences of demsity due to

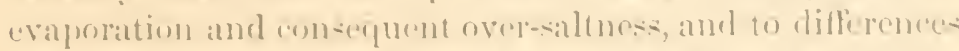
of tenuperature betweren the watery at the poles and at the equator. This theoretical direulation douletess exist- in a more or lese modition form, and alliect- the atchal motion of

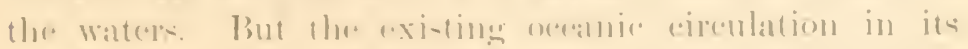
erreatert part i- due dimety to the influence of the tradewinds, and is, compalatively -pratking, superficial. 
We know that the deep sea is very cold. Cold water sinks, and a submarine polar indraught of cold water must replace the constant streams of tropical surface water which flow away from the equator, in order that an equilibrium may be maintained. The warmest water that has been found in the deep-sea (over 100 tathoms) is at $50^{\circ} .5 \mathrm{~F}$. in 2,550 fathoms ; the ordinary temperature is but little above the freezing point. This, however, does not affect the life of organisms existing there, which are all cold blooded, many of them coming into shallow water in the Aretic regions.

That many problems in regard to the deep-sea are still unsolved, goes without saying. Time does not permit me to discuss them here. In conchusion, I will briefly sketch the conditions of life at the bottom of the deep-sea.

In the first place, fishes and organisms of almost every marine group lower in the scale than fishes, are to be found in the deeps. In order that these animals may exist where the pressure of the water may be several tons to the square inch, it is indispensable that their fleshy tissues shall be so loosely constituted that the water shall be able to permeate then thoroughly, and thus itself equalize the external pressure. Hence, the fishes and other large animals inhabitating the abysses are, so far as their flesh is concerned, of an almost gelatinous consistency. While they might probably survive a very gradual change of pressure and be able to live in shallow water, yet when they are rapidly brought up from the depths in a dredge, they are invariably dead, their internal organs usually turned inside ont, their eyes starting from their heads, and their forms more or less altered from the sudden decrease of pressure and expansion of the tissues.

Other inhabitants of the sea-bed have rigid exoskeletons or shells, but the soft parts are always permeable.

While most of the deep-sea animals are small, fishes, certain spider-like erustacea and some echinoderms attain a considerable size.

As the depths must be almost entirely dark unless lighted 
by phosphorescent animals, we might expeet to find these creatures banded or generally white. This is true of many of them, but others of atl groups, are more or less lrilliantly. colored. From disuse in some forms, the eres hate becene abortive or entirely lost; others have very larere and delieate eyes, suitalble for seeing by a very small amount of light; ret still others have eyes of about the eharacter normal in the groups to which they belong. The extreme quict and uniformity of the enviroument at the sals-bed is firsorable to the derelopment of delicate markings, and details of sculpture in the latel parts of shells, etc., and the alby:-ill animals are notable for their extreme grate and beaty in this particular, and singularly enough, also in many species for the remarkible elegince of their pearly lustre. With no struggle for existence, a wonderful range of variation developer, unchecked by natural selection, and it is harel to say in certain groups what is a species.

sea-weeds do not grow at great depthe. hence these animals are all carnivorous. At first sight it would seem ats if they would destroy one another, but it must be remembered that even in the open ocean there is a constant min of animal and regetable matter slowly falling from the surface toward the bottom. Mr. Mo-eley judges from experiment that small marine animals (salpa) fall at the rate of about at mile in two lays, while the saltness of the water prevents rapirl decay. I have found grase roots, land and fresh water shells in dredgings from soof fothoms. It is still a matter of some eloubt whether ectain little shells belonging to the Forrminifore and fouml in incalculable numbers on the seatbed (which in many (ases is made up) of their remains) actually erer live at the hottom, or whether they, too, are rerived from the vicinity of the surface and sink only when deat or dring.

but I have alrearly trespasied too long on your grood nature, and will eonchute this discourse by referring those who would pursue the subject further to the anthorities previous ly mentioned, from whom I have derived much as- 
sistance in the preparation of this lecture, and to whom the exploration of the sea-bed is chiefly due.*

* Depths of the Sea: C. Wyville Thomson; New York and London, Macmillan $\&$ Co., I 873 .

Deep-Sea Exploration: a Lecture by J. Gwyn Jeffreys; London, Svo., Van Voorst, I 88 I.

Deep-Sea Sounding and Dredging: C. D. Sigsbee, Lieut. Com. U. S. N., Asst. U. S Coast Survey; Washington, Gov't Printing Office, I 880.

U. S. Coast Survey Reports, 1867-1880.

Bulletins Museum Comparative Zoology, Cambridge, Mass., Vols. I-IX, I867ISS2.

Reports of Jeffreys, Carpenter, Thomson and others in the Proceedings of the Royal Society, I868-I88o.

The Norwegian North Atlantic Expedition-Zoology, (etc.) Collett, Koren and Danielssen, \&c., Christiania, folio, I8So-81.

Thalassa, an Essay on the Depth Temperature and Currents of the Ocean, by John James Wild; London, Marcus Ward \& Co., 1877. 


\section{HOW WE SEE}

Lecture delivered in the United States Nationd Musem, April 21, 1S.Sz. Ly Di. SWAn M. BURnetr.

\section{LADIES ANI G GENTEMEN:}

When man tirst fommel limself capable of forming a proper jutgment of the workings of Nature, the sense of vision must have exeited in his mind an emotion of the greatest wonder. That he was rognizant of objects situated at distances very remote and heyomel the reach of his touch, and through a medimu the very existented of which was a mystery above his anmpelansion, must have serened fo him at problem which hefied eren an attempt at solution. We are not awale that any offort has been made by silvage or latrharous tribes to aceomnt for any of the phemomena of sight. They give reaty explanations of the cause of thonder and liglining, of the origin of men and aminals, the creation of fire and other natural phenomena, but the sense of sight is so wholly molike amything else with which they are firmiliar that they have no analogies to fall back on, and must aceept it as a primary grift of the bivine spirit. It is

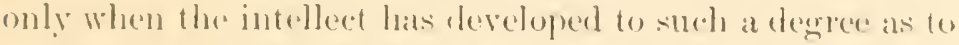

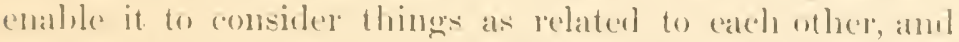

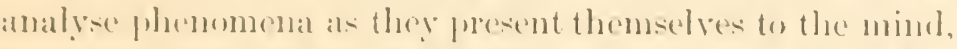
reducing them as fat as posible to their comstituent che ments, that the sense of rision is ronsidered a sulject within the scope of human investigation. The physiolory of vision, therefore, belongs preannenty to the serentific (rat in the history of intellectual develepment. It limk nuplace, so fine as I know, in the era of superstition. Tu tell you what the scientific method of thomght hats aleenmplished in this field is the olject of the rematris we sinall make this aftermoon.

In the study of the phemomema presenterl hy the sense of vision we find fonl separate links in a ehain of serpuences. If any one of these links is missing therr (all be no sensation of sight.

The first link in the chain, naturally, is the object to bo seen; the second, the medimm connecting this object with 
the eyc; the third, the eye itself; and the fourth, the nervous center which converts the impression made on the eye into a sensation.

Of the object to be seen, but little need be said. All that is necessary being that it be found in the medium which brings it in relation with the eye, that is to say, it must be placed in what we call the light. As you well know, no object situated in what we call darkness can be seen. The object may be luminous within itself, that is, it may generate the light which it gives off, as in the case of the sun, candle, lamp, fire, sce; or it may merely reflect or throw off the light which comes from some other source, as in the case with the large majority of objects by which we are surrounded; but it is absolutely necessary for the purposes of vision that light proceed from it.

This light is the second link in our chain, and it is one of the most wonderful and mysterious of the workings of Nature. What is light? Is it a something, oronly an essence or a spirit? What are the laws governing its action? These are questions which the earlier philosophers asked themselves and sought, for a long time in vain, to answer.

We will not occupy your attention with any of the theories before the time of Newton, as it was his genius which first placed the study of the operations of light on a solid basis.

His theory was that all luminous bodies gave off minute impalpable corpuscles which passed directly into the eye and affected the retina and optic nerve. This hypothesis was, of course, not susceptible of demonstration, but he succeeded by it in accounting for many of the manifestations of light in a manner more satisfactory than had been done by any other theory then known. The corpuscular or "emission" theory, haring the weight of the great name of Newton attached to it, was accepted by most philosophers of his time, and, with the additional weight of tradition, affected many who came after him. All theories respecting the ultimate facts of any phenomenon in nature must be based largely on à priori reasoning, for no ultimate knowl- 
colge is provalule. (Hur tacts reach batek only to a certain point-never to the heginning. Secenee is constantly pushing back her lime of primordial data, but it is hardly probable that the time will over cone when the essence, so to speak, of any manifestation in nature ram be demonstrated. Natures datw, we (an study amd muratel-the origrin of these laws will probably eror romain an musolved mystery. The natme of light is one of these mysteries which can be: approacheal by speculation alone, and as none of the postulates meed be demonstrated, the field for the axereise of the speculative faculty is practically unlimited. Nowton adopted his corpusenlar theory, not because he conld ilemonstrate the existence of the rorpuseles, but because by so doing he thought he was explaining the phenomenn with the least violence to known laws and the sciontifir princijules of the time.

There was one grealt original mind, however, which came after him, that refused to accept any theory on any other man's anthority, however grout that man might be. 'This Was Thomas Young, probably the most universal genius Englam has given to the world. Thomas Young did not. consider the corpuscular theory of light satisfactory, alid proceeded to revive and modify what is alled the undulatory theory, which had been broalded by Ihurgens hefore the time of Sewton. By this theory he was enabled to aceount in at more entistent and satisfirctory manner for some of the manifestations of light than contal be done by the corpuscular theory of Newton. This mululatory hypothesis as promulgated by loung, is the batsis of all modern speculations as to the nature and laws of hight. In rommon with all theories dealing with the risential nature of things, it deaws largely upon our crerlulity, and askis us to aterept as data as many postulates which have nover becm and which ain, from the very nature of the case, never be proven as does the corpuseular thenry of Newton.

In the first place, wo are requirerl to stypnse the existence of an ether which is coextensive with the universe. It fills the interstellar spare to the farthen fixed star, whose distance 
is incalculable, and insinuates itself into the infinitesmally minute interstices of the hardest known substances. It exists alike in a vacuum and in the substance of the diamond. It is of such extreme tenuity, that a mass of it as large as the earth weighs only a few grains. It is the least material of all substances, and yet it possesses a tension or elasticity far in excess of any matter of which we have any knowledge.

This is the medium through which that form of force we call light is supposed to act. It has, as you see, no existence whatever as a fact capable of demonstration by any of the ordinary methods of proof. It exists alone in that highest faculty of the mind which, by its creative power, sets man above the beasts of the field-the imagination.

But our task does not end here. We have the medium, but we have not the manner in which this is acted on to produce the effect we know as light. Again the inagination must be brought into action. The mind which first conceived of light as being a force, the result of wave motion, gave us the key which has unlocked some of the deepest mysteries of Nature, and made modern physical science and all that belongs to it, and has resulted from it possible; for the foundation of the physical science of the present day is the fact that all energy is but a mode of motion. I think it can be broadly stated that all forms of energy, whether in the organic or inorganic world, are but modes of motion. The ancient philosopher, when asked to define Life, moved his arms, drew the air into his lungs, and expellecl it, and said, "This is life," meaning that all we knew of life were its phenomena. But he explained better than he was aware of. He expressed thus the idea which underlies the modern concepts of Nature and her laws, that life is motion. Without energy, as expressed by some form of movement, there can be no life; and life is but one form of cnergy, one particular kind of force. All other forces in Nature are likewise but representations of some kind of motion - they are not Things. The whole of the teaching of modern scienee tends to the demonstration of the fact that there are but two Things in nature-matter and its motion. 
Applying this principle to the ether, loung supposed that the light force was due to an unclulatory motion set up in it by the vibrations of the molecules of luminums hodies. It is now a pretty well demonstrated fitct that when bodies get into the condition known als "hot," a change takes place in the ultimate particles of the matter composing them. They are set in vibration. The more heated they beene the more extensive will these molecular vibrations be: and as the space oceupied by the molecules in a state of vibrittion is greater than when they are at rest, the substance when heated is larger than when cool. The motion of these ultimate molecules is communicated to the ether by which they are surromded, and it is set in undulatory motion, just as waves are produced on the surface of water when a body is let fill upon it, which disturbs the relation of its molecules. As the motion of the molecules of the heated body is regular, the wave motion communicaterl to the surrounding ethel will also be regular, that is, the watre will follow each other at regular intervals of time.

$\mathrm{U}_{1}$ to this point everything must be taken for sranted, for, as I have said, not one of the aceepted ficts is capable of experimental demonstration. Acepting this much, lowever, we ean deduce ecrtain latws which are capable of substantiation by experiment, and by them we are able to explain all or nearly all the plienomena of liglit and vision. Thougle we have shown you that light is only a form of force-a mode of motion-it will be more consenient to speak of it as a 'Thing, withunt referenes to the ether or wave motion. Thus, when we saly that light travels at the late of $1 \$(j, 000$ miles per second, we mean that the motion communieated by the luminous body to the ether is folt 156,000 miles away at the enel of a second of time. There are a few fixed law governing the action of light, to which we briefly call your attention, beeause on them depends all our knowledge of the physioluery of vision.

lu the first plaw, we know that light moves instraight lines, and never turns ont of its course unless it meets with sone substance having the property of deflecting it. 'There 
are two forms of deflection. In one the light is thrown back by the surface of the interposing body in the direction from which it came; that is to say, it is reflected. In the other it passes through the body, but its course after its passage is not the same as before; in whieh case it is said to be refracted. It is with this latter we have especially to do in treating of the physiology of vision. Without entering into a detailed consideration of all the laws of refraction, we will state that when the refracting body has a certain form, which we call a lens, all the rays coming from any one point of an object are, after refraction, brought together in another point. Such a lens is shown in the accompanying figure.

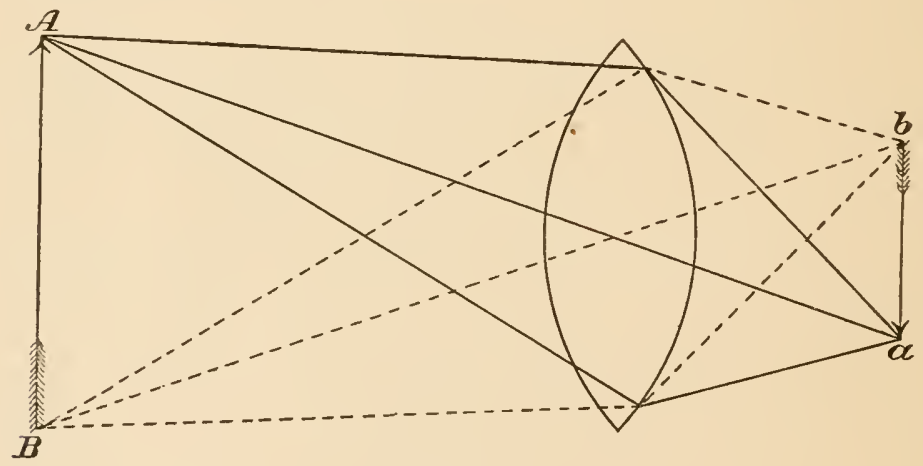

Fig. I.

All rays proceeding from the point $\Lambda$ are, after their passage through the lens, mited in the point $a$, and all rays proceeding from the point $\mathrm{B}$ are, after refraction, united in the point $b$, and rays proceeding from all points between $A$ and $B$ are united at points between $a$ and $b$. The result of this is that in $a b$ we have an image of the object $A B$. There are two peeuliarities of this image to which I want to call your attention. The first is that it is much smaller than the object $A B$, and the second is that it is turned upside down. Now, when we eome to regard the eye as an optical instrument, we will find it to differ in principle in no essential particular from this simple lens. The whole function 
of the ege, from an optical point of view, is to form at smatl, dearly detined, but imverted inmere of externat objects on the expansien of the optic nerve. We will now proceed to

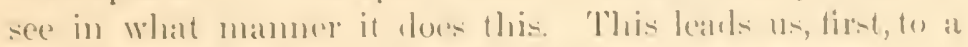
brief deseription of the general anatomy of the eye.

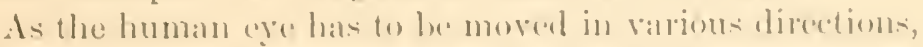
independent of the movements of the head, it must be more or lesestobular in thape. It is thus allowed to lit more easily in the bung orbit in which it is encatsed, and the $-i x$ muscles which move it can more reatily control its motions. The ball of the eye is a hollow ghole antaining the leneses necessary for produring images of external objects and the expansion of the optic nerve on which these images are to fall.

There are certain physical eonditions which have to be fultilled in order that the image produced by any optical apparatus shall be elear and listinct. We will take the photographer"s camerat as an illustration. In the first platee we fincl that the whole anplatatus is encared in a box for the protection of the more essential parts. Wir observe further that this box is linest with black in order that no light shall be reflected from its sides that will mar the distinctness of the image forment hy the lens. The lens is plated in front, and at the batek there is a sereen of gromol-ghas on which the inatge formen by the lens falls. When sitting for your photograph you will aloo have noticen that the operator was at great pains to properly focus the instrunent so that the image should be clearly formen on the gromel-erlas plate at the baek, and if you take the pains to examine his instrument you will find just helinel the lens a blark diaphragm with a rircular hole mueh smather than the lens. 'This lat-

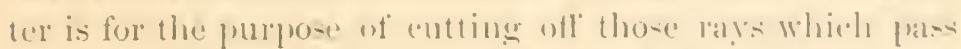
through the parts of the lens near the abese. These lays, unless the lens is ground in the mont alecourate manner, ardel nothing to the distinetmens of the imatere, but, on the contrary, detract from its clearness of ontline.

Ill these enditions are carefully fulfilled in the eye, ats you will see by reforenee (1) the alecemplanying diagram. 


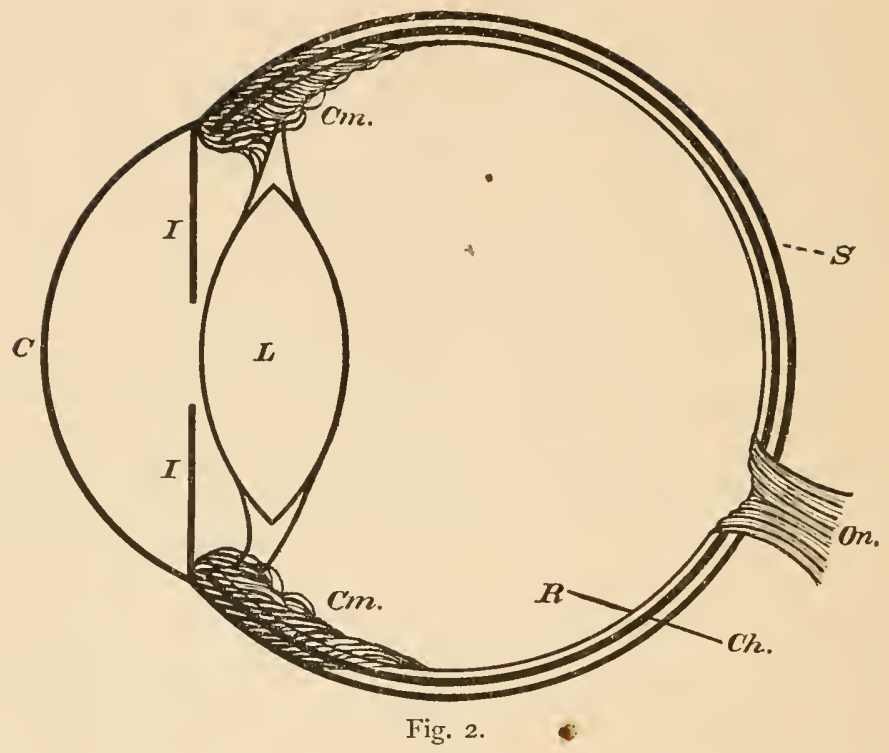

You have in the first place the outer box or shell in the sclerotic coat, $(\mathrm{S}$, ) which is a tough membrane forming the posterior four-fifths of the ball. The anterior', one-fifth, is formed by the cornea, $(\mathrm{C}$,$) which is only a continuation of$ the sclerotic with the remarkable and highly important difference that it is transparent. This cornea being a curved surface, acts upon the light in the same manner as the lens in Fig. 1, and forms one of the two refracting surfaces which produce the images of objects.in the external world upon the expansion of the optic nerve (On) at the back of the eye called the retina, (R.) The other refracting body is the crystalline lens, (L.) The iris (I) represents the diaphragm, and the hole in it is the pupil. The choroid coat, $(\mathrm{Ch}$,$) while holding the greater part of the blood-vessels$ which nourish the eye, also contains a large quantity of pigment, which serves the purpose of the black lining of the photographer's camera. We have thus all the essential parts of a perfect optical instrument, and by the large majority of persons the eye is considered the most nearly perfect of all instruments of its class from a merely physical 
stamelpoint. This is, howerer,at great crror. Considered as an optieal instrument. Where function it is to form the elearsest posible imagere, it is defortive in almost all its parts, atud

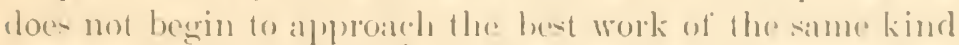
as done ly man. Helmfolt\%, the great Cieman physicist, hats said that if all eptician were to semel him an instrument

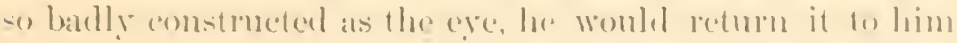
with a screre reprimand for his carelessness. But wo must bear in mind that the eye is all organ of sense as wedl at at1 optical instrument, anml with all its defeets, is cal ablule of rentdering us most aflicient servine.

As I have sidid. the function of the ege propere is to form

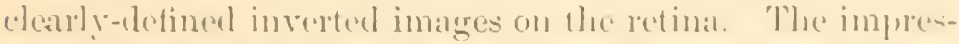
-ion or changer frodued by this intige are convereal to the

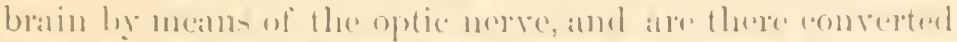
inte a rensation. I conlused image will caluse al contived semsation, and a clearly-defined image al corresponding sensation. It is therefores of the highest importance that we alwars halreretinal images whose outlines are shapp and distinet. This is very easily areomplisherl when the object and the retina ocenpe certain relative positions to cald other. It is one of the law of opties that when the objeret is at a cortain distane (within specified limits) from the lens the imate will be furmed at a certain distance from it on the other sille. If the distance of the object is clusugecl. the distane of the image from the lens will also be altereal.

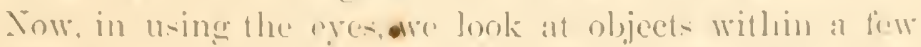
inche of 11 s and also at these at immense distances. Thu lange of areommodation, as it is callecl, extenets from four inche from the ege to infinity. If we are to have elearly actinesl image of all whects in this extensive lamere some rlange must take phase in the are corresponding to the

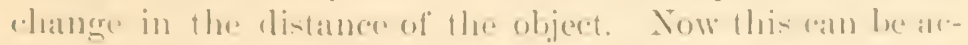
complisherl in oine of two wals-cither by a change in the distance between the lens and the retina, or by an increase in the eurvature of the refracting surfices. The first of then annot be readily aceomplished, becaluse the rye ean-

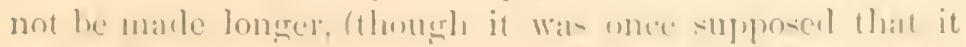


could.) The adaptation or accommodation of the eye, therefore, for distinct vision at different distanees is affected by the other method; that is, by a change in the curvature of one of its two refracting surfaces. It has been abundantly demonstrated by observation that this change is effected by an increase in the curvature of the crystalline lens, brought about by the action of a muscle situated on the interior of the eye called the ciliary muscle, (Cm, Fig. 2.) By the contraction of this muscle the lens is rendered more convex, and objects lying nearer the eye have their objects formed more clearly on the retina. A reference to the diagram (Fig. 3) will show how this is accomplished. When the object is situated at $A$ the image is formed on the retina, $R$, at $a$, when it is at $B$ it is formed behind the retina at $b$. In order, therefore, when the object is at $B$, to have its image at $a$, the lens, $\mathrm{L}$, must be made more convex, as shown by the dotted line.

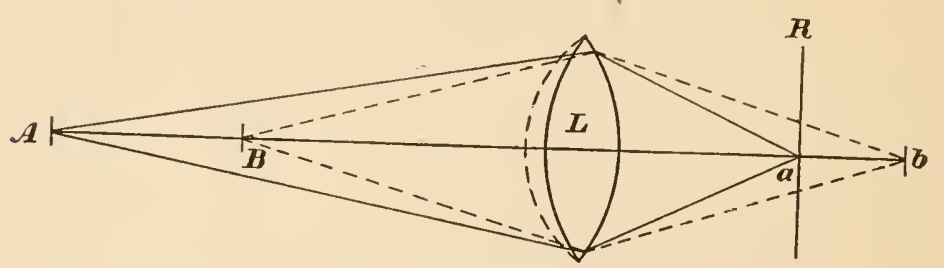

Fig. 3 .

It is this failure of the power of accommodation or adaptation of the eyes to objects close at hand which constitutes presbyopia or old eyes. With trancing age the ciliary muscle becomes stiff and less powerful, and the lens becomes harder and alters its shape less readily, and the consequence is that near vision is rendered less perfect. This is remedied by plaeing in front of the eye a lens which represents the power that has been lost by the crystalline lens. Quite the contrary of the generally accepted belief the eye does not become materially flatter with age.

We have now the image of the external objeet pictured clearly and distinctly upon the expansion of the optic nerve at the bottom of the eye, and with this the whole of the function of the eye as an optical instrument is ended. 
In a general way the eye is comsidered by the large majority of persoms as being the organ of vision, whereats, in trutl, it is only one of the organs concernerl in bringing alwut the semsition of sight. Thr eye maty he anatomically in a perfectly healtly endition, amel the imares of objects

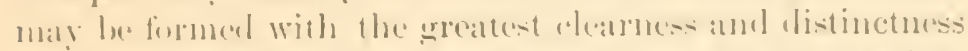
an the retinat, and, yet, the power of secing he wating. 'Phr image furment on the retina produces only an impressim. and this mast he ennverted into a susalim betore the

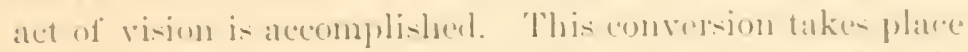
in the hrain. That there is a certain portion of the brain

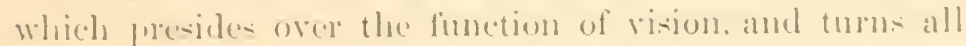

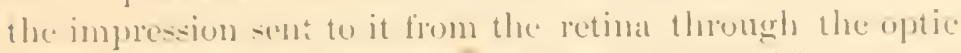

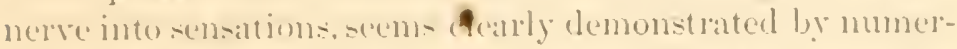
ous experimentio on the lower animals. The eye, therefores, i- only une of the instruments of vision.

Let $u=$ mow proceed to inculue what it is we learn by the abet of -eoing-what knowledge of the external world is bromglit to the mind through the medium of the eye. IT learn, first, the jo-ition of ubjects in space: thejr distance

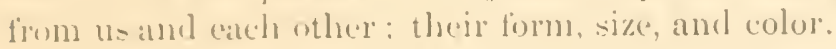

It may le premiserl that rery little of our knowledere obtained in the sen-e of rision is furnished alone by the imase- formes on the retina. In the development of the intellecet the s'nses of sight and tench go hand in hand. ln filct some recent -perulations seem to point to the faret that sight is only a highla developerl sense of touch. Be that ats is ma! this important fict is clearly atablished, that the sen-e of sight is an exlueated sense. It is not inborn: it i- not instinctive, at least, in the higher forms of

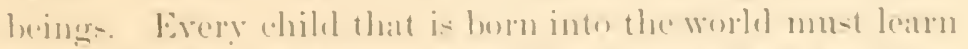

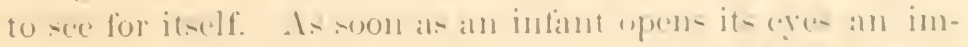
age is formed on its retina, but that comvers to it - younger mime no definite knowledere excepte probably, as to outline. suppose. for cximple, a lattle, with a ring at one end, and a ball at the other, is hell hefore it. The imatse of this objeet is formed un the retina, but it is mp-ille down, as are all retinal images. How then is the ehild to learn the true re- 
lation of this object to itself? This is a question which puzzled philosophers for a long time, and many explanations were given to account for it. By some it was supposed that in some way the image was "righted" before it reached the retina, by others, it was thought that it was turned right side up on its passage from the retina to the brain. But it is by no means neessary to assume any such mysterious processes. The explanation, when we once find it, is simple enough. The image, as we have before remarked, is undoubtedly formed upside down on the retina. But we must bear in mind that this image only produces an inpression-the interpretation of this impression is made by the brain through the faculty we call the judgment. Now the judgment is often the resut of several impressions, received, it may be, from several different sources. In the case of the rattle, the impression made by the image must be verified by the impression of touch. The infant reaches out its hand and finds that the globular end of the rattle corresponds in direction to its feet or downward, while the ring end corresponds to an upward direction or towards its head. It does not make any difference that the lower or round end of the image corresponds to the upper part of the object, and vice versa. The position of the retinal image is a matter of no importance, so long as the judgment, guided by touch, places the object in its proper relation with the individual and surrounding objects. Physiologists call this placing of objects properly in space the "law of projection," which, being interpreted, means that all impressions made on the upper parts of the retina are "projected" or referred downward, and all impressions made on the lower parts of the retina are projected upward; and as the relative position of the objects in the external world are in 110 wise affected by their inverted images on the retina, no confusion can arise.

The same principle applies when we judge of the distance and size of objects. The size of a retinal image gives us no idea whatever of the size of the object or its distance from us. These two ideas are inseparably connected in the 
mind. The distance of an olject from us grives us important clata for forming judgment as to its size and the sime of it if known, emables us to form an idea of its distance. You will readily see the truth of this, when gom know that a five cent piece, held a fow inches from the eye, forms as laree a retinal image as the sum which is many millions of miles further ofl. Plyysiologists womld tell you that they both subtend the same visual angle. so it we wish to have a definite idea of the actual size of an olject we must know its distance from us ; and, on the other hand, in order to judire of the distance of an object, hy the size of the retinal image, we must know its size as compared with other objects. In the julgment of distanee, however, there are other factors not to be overlooked. One of the most important of these is what is called the "muscular sense." In looking at oljects close at hand we bring into play the accommodation of the eye which, as I have alleady told you, is hrought about by the action of the ciliary muscle. 'The nearer objects are to us the stronger must be the arction of the muscle in order that we see distinctly, and we come naturally to associate a strong effort of the aceommodation power with nealness of the object. The amount of convergence of the two eyes, which is necesily in olrler that both be fixed mpon the same object, also furnishes us with inportint knowledge of the distance of objects from us.

We come now to consider one of the most remarkable at tributes of objects, a knowledge of which is griven us through the eye. We allude to that wonderful quality called color. In the striet sense of the worrl, however, no object is colorel. ('olor is a property of light, while those objects which appear to us colored simply decompose the light falling on them into its diflerent color constituents, sending to the ere some one or more and absorbing the others. For ordinary purposes, however, it is more ronvenient to ronsiler rolor as belonging to the object, but we must bear in mind, at the same time, that each color is represented physically ly a certain number of vibrations of the luminiferous ether. Thus, 451 million million vibrations of the ether in a 
second of time represent the color we call red, while 789 million million vibrations correspond to violet, and so on. In object we call red, therefore, sends to us from the white light falling upon it those waves of the ether which make 451 million million vibrations per second. All the other wave lengths of the ether are lost, and most probably by having their motion converted into a molecular vibration of the substance of the object.

When we call to mind the great number of separate colors and the infinite rariety of their shades, which we recognize as distinct sensations, we at once appreciate the extraordinary delicacy of perception by the visual apparatus.

The satisfactory explanation of color perception has always been among the most difficult problems with which the physiologist has had to deal. The theory on this subject which has held the longest sway over the largest number of minds is that of Young, as revived by Helmholtz. Until within the last few years fe or no physiologists had the temerity to doubt the sufficiency of this hypothesis.

This theory starts out on the basis that there are three fundamental or primary colors, by the proper admixture of which all other colors and shades of colors can be produced. It is now the popular opinion, which was formerly upheld by scientific anthority, that these so-called primary colors are red, yellow, and blue, beeause from a mixture of pigments of these colors the painter can produce a large number of the colors he finds of use in the practice of his art. When, howerer, we come to deal with the pure colors of the spectrum we find that these are not the fundamental colors. It lias been found that from the mixture of spectral red, green, and violet, all the other colors of the spectrum ean be produced, and, also, that when these colors are mixed in due proportion white is the result. For this reason, red, green, and violet have been accepted as the primary colors by most modern scientists.

Newton believed that the particles representing the individual colors (according to his emission theory) affected the retina "according to their nature and bigness," but Young 


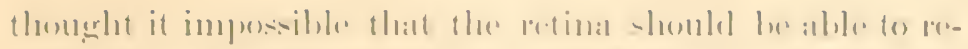

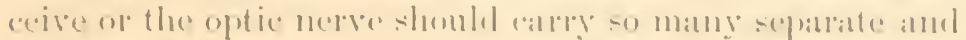

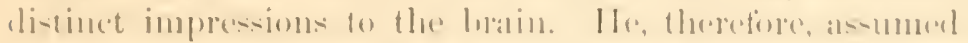

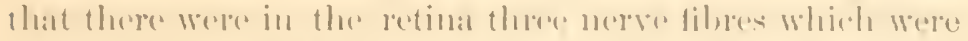

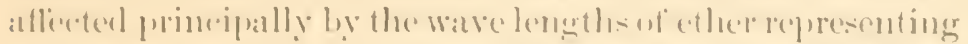

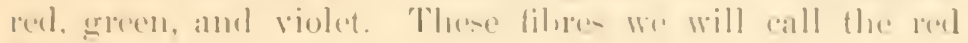

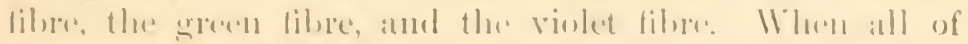

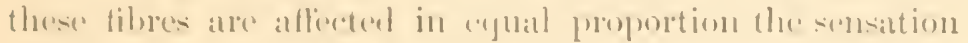

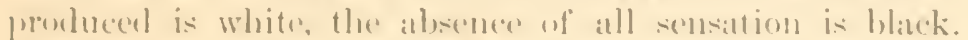

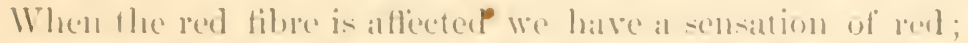

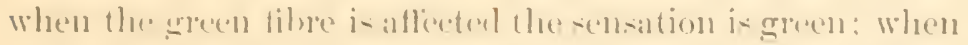

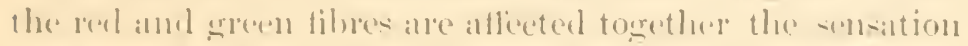

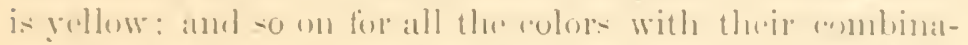
lions amel shades. Now this is all rergs simple and plau-i-

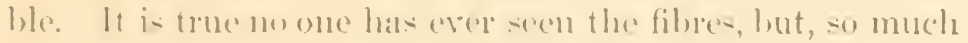
lass to he taken for eranted in this departument of seciontific investigation. that this point might realily be eoncederl if there were no other obstaleles in theway of an aleceptance of the theory. Searly all the phenomena of eolored vision ean be acrounted for on this hypothesis if we -o modify it as to allow wf some ation on loth the gueen and violet fibre- by the rent rays and some action on the arrecu hy the red ame rioled. and on the violet by the reel and green. For

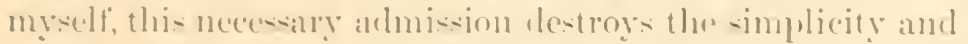
beauty of the hypothes. for I hold that the plenomente of vision, when theroughly molerstuot. will he found to be extremely simple in their challetel and in kephing with the known laws of light and it-antion on simple botics.

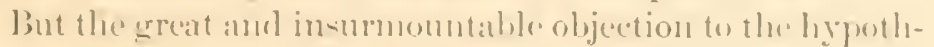

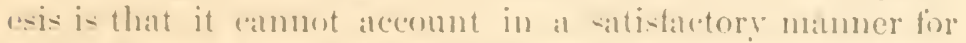
all the phenomena of (o)lor-blindur... An acerptable theory in reararel to the finnetion of an orgatn in health must atceount also for all the deramgements of that fimetion.

Withont entrering into amy details, it may lu briefly statted that there are some phemomenat presenterl hy the color-hlimet, which cammot he satisfactorily explanined hy the YoungHolmholt\% hypothesis. Physiologrists are. therrefore, broming dissatisfied will it, and are serking for ond which shall 
be more in keeping with known facts, and more in accordance with operation of analogous functions in the human body.

The theory of Prof. Hering, of Prague, has received most attention from those who have been bold enough to reject the hypothesis of Young.

This theory presupposes the existence in the retina of three chemical substances, which, on account of their presumed functions, are called the red-green substance, the blueyellow substance, and the black-white substance.

An action of light on the red-green substance, which tends to decompose it, produces red; while an action which tends to regenerate it produces green. I decomposing action of light on the blue-yellow substance causes a sensation of yellow; a regenerating action, the sensation of blue; while a destruction of the white-black substance produces white, its regeneration black. According to this theory there are three pairs of opposing colors, (including white and black,) and the fundamental colors are four, red, green, blue, and yellow, and the so-called complementary colors are in reality antagonistic. Thus you see Hering's theory is more complicated than that of Young, likewise demands the acceptance of unproved and unprovable postulates, and makes even greater draughts upon our scientific faith. It has this advantage over its rival, however, that it explains in a much more satisfactory manner some of the phenomena of color-blindness.

The fundamental wbjection to this theory, as to that of Young-Helmholtz, is that it presupposes the existence of new tissues, the like of which are not found in any other part of the human body, and novel reactions of these tissues to light. It may be accepted as a law of universal application that Nature always works in the simplest manner possible, and we have no right to suppose that the function of vision forms any exception to the rule. Is it possible to account for the perception of colors in a simple and direct manner? I think it is, and that, too, without doing any violence to laws, the existence of which lias been estab- 
lisheel by proof as positive as science can furnish us. I have endeavered to elo this in a patper real befure the Philosophical society of this eity, in December, 1850.

It would not le pertinent, at this time, in enter into an claborate exposition of this theory. Let it suffice to say that the two findamental filwte on which it is based are: 1st. The evidence which comparative anatomy and physiology fumish that the cye is but a highly specialized nerve of common sensation. It is a lact whirh has been thoroughly wetl estahlished hy observation that certain of the lowes animals are aflected by light over the whole cxtent of their external surfice. As we asecud higher in the scale of exintence the diflerentiation of function becomes sreater, anul while the grosser effects of the ether vilsation ares still felt in the form of heat on the surface of the body, the finer vibrations are appreciated only in certain restricted localities known as cees; for it is a fact which is elisputed, 1 think, by no one that heat and light are both due to vibrations of the sime ether, differing in decree only, and not at all in kind.

Prof. Prever, of Jenal, hals, within the last few months, arlvancerl rery similar views, and shows that the sense of heat and the sense of eight hear a very strong analogy to cach other. The sicond finet is the reaction of simple substances to light, as manifestal by a change in their molecular structure. It hats long been known that certain colors have grater dhemical powers, for instance, than others. The so-ralled atrinic power of blue or violet is greater than that of yellow. This is only a short method of stating the fact that the change in the molecular structure of the aflected body is much greater by light rays of short-wave lengths than it is by light bay of longer-wave lengths. The aletion of light on the metil silenium, and on other substances used in the ennetruetion of thr photophone, is an example more to the proint. Sot only is the eleetrie conductability of these substanes merlified ly slight changes in the inlonsity of the light wares. but Prot. lecil has fomed that this

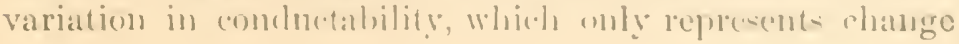


in molecular structure, is also different for the different colors. Moreover, the effect of this change in molecular structure is conveyed to great distances through other media, and there makes itself manifest under the same or some other form.

It is thus evident that in the inorganic world the light rays do produce different affects, as manifested by molecular change, according to their different wave-lengths. We have only to apply this law to the action of light on the retina to have a theory of colors at once simple, and strictly in accordance with known principles, and without the necessity of inventing new tissues or extraordinary reactions of tissues to light. In this theory rariation in sensation will have its basis, not in complexity of tisue, but solely in the varying action of the affecting agent.

In accordance with this hypothesis we have only to suy)pose the retina to be a body whose molecular structure is so delicately fashioned as to allow it to respond promptly to the slightest variation in the wave-lengths of light rays. We know that up to a certain point we can discriminate between fine shades of intensity of light. The educated eye of an artist can detect as minute differences in shading as he can in colors. This we must suppose is due to the judgment which has been educated to discriminate between small differences as to quantity, and there can be no reason for not supposing that we can learn in like manner to distinguish between small differences in quality as manifested in the slight alteration in the molecular arrangement of the retina brought about by the different colors. Every impression, thercfore, produced by each color will be conveyed independently of other impresions to the brain, and will there be tumed into a distinct and individual sensation. But even in this theory there is no necessity for supposing that all the color sensations are primary. We can have here, as in the other theories, a mixture of sensations in the production of some colors, and the numerous combinations which are known under the name of secondary colors. Purple, for example, will be the sensation resulting from a combi- 
nation of the two sensations of red and blue. The same holds true for the hromes and the varions other tints of that orrler. The rombination, homerer, is masle in the haim and not in the rotimat.

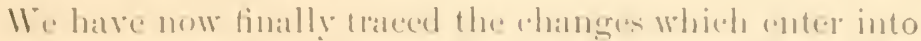

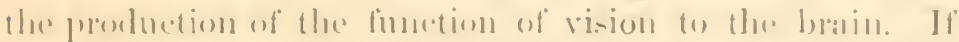

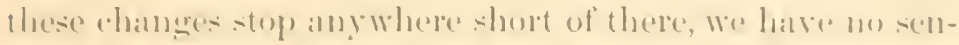
-ition. no light. In fart, it is not vision alt all. for it is llu braiu which orermules all, and tran-forms impresions into

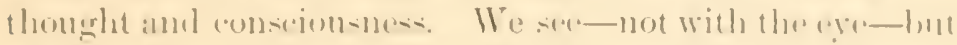
with the hrain-the ere heing only ane of the instrumentwhich the brain use to hring to it knowlederent the change which take place in the onter worlel. 'Phis knowledge it

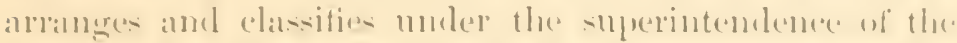

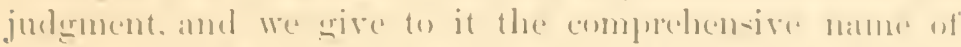

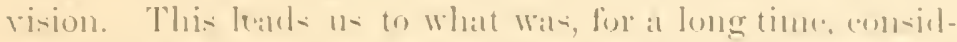

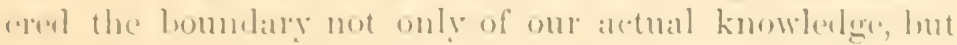

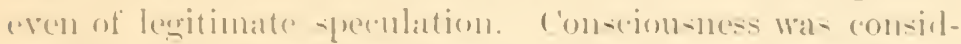

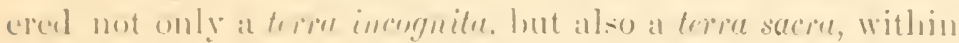

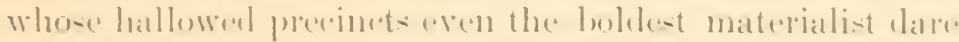

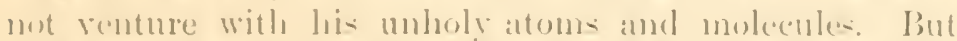

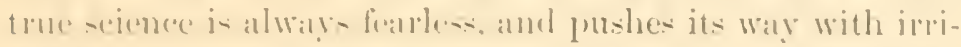
sintable formes into arery aremue where honest investigation uffer-for it- lalore the -mallent morlicum of new truth.

Inatumieal soivene has traced. by its mmmerous amel paltient diseretions. the optic nerve to its termination in a reptain portion of the hain. As mothing in the working

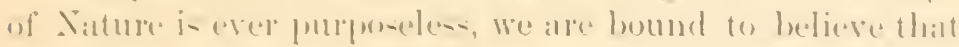

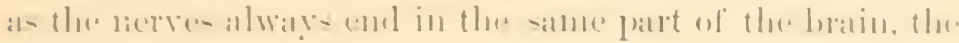
brain in that immonliate vicinity must have mertion with tram-frommtion of light waves intu vi-ion.

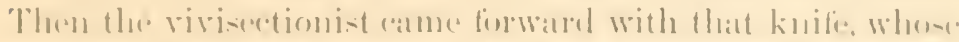

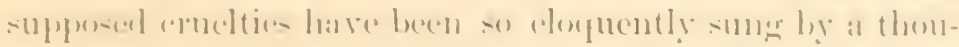
- atul - tion of the brain from the living ereatume, and the animal lereame (ompletely hlinel. Thus one more -tolle of truth was aleled to the stowly grmwing temple of human knowl-

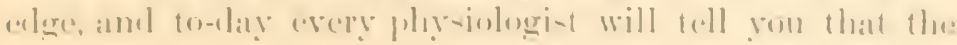


sense of vision resides in the cortical substance of the posterior cerebral lobes.

But the human mind, ever unsatisfied with its present knowledge, inquires still further, and asks what are the alterations which take place in that particular portion of the brain when the changes wrought by the light waves on the retina are brought to it through the medium of the optic nerve?

Let us, for a moment, look at it dispassionately and without prejudice, as becomes all seekers after the truth. Let us remember in the first place that we have been all the while dealing with matter. The object to be seen is material, the ether, if it exists, must be material; and we know that the optic nerve and retina are matter, and the brain is a substance analogous to these in anatomical structure.

If we take a self-luminous body as the object, we know that molecular change, in the form of motion, forms the first link in the chain of sequences of which we spoke at the outset of this lecture as necessary for the function of vision. These motions are communicated to the surrounding ether, and by it are carried to the retina. Have we any right to suppose that the molecular motion stops there? Certainly not. There is no fact yet demonstrated which militates against it, and in this hand to hand warfare of Science against the hidden secrets of Nature we claim all to be for us which is not positively against us. On this principle, therefore, we are amply justified in assuming that the ether has only been the medium of transference of molecular motion from the body to the retina. This motion is then transferred through the optic nerve to the demonstrated center of vision in the brain. Does molecular change in the form of motion end even then? Having followed it thus far we can see no satisfying reason why it should. And the last link in the chain which is discernable by our short-sighted vision is a change, manifested by a form of motion in the ultimate molecules of the brain. How this motion of the molecules is converted into consciousness is a problem for the solution of which we have not even the 
rudiment of a fardenty. We only know that the plienomenon began as motion, and that as motion it ensled. But berounlah, bevond-is an impenetrable darkness. Wo emerged from an eternity of ignomanee, we chel at the brink of an ctemity of the unknowable. In the infintesmally short span betwen these a wo mighty cternitice we are permitted to examine into the workings of Siture's latwe fo follow ont their relattions to earch othere, and apply them, as far as we are able, to the explatuation of the phenomena ly which we ale surroumled: lout of the origins of these latw: we are, as ecien-

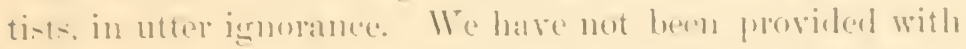
a power to grasep at aven the hecriming of an idea which would lead us norarer a solution of these problems than we now are. Anel als at the beginning sor at the cucl. 'There are some things which are not only unknown but unknowable. It is utterly in possible that we can ever know low light walve or onuml waves are eonverted by the material (1) wan of the hrain into eonsciousnes: and thought. 'That this is areomplished he the hrain we know, and that it is throurd at change in its molecular strueture ashits harelly of a doubt, but there we must pause. We have reached the linits of our po-ible knowlerlge, and from any attempt at penctrating the darkness berond eren the imagination shrinks, nverwhelmed by the enciousness of its ntter puwerle--ne-s and incapacity.

Ind now, larlies and gentlemen, we have finished all we dreigned to tell you of what we know of one of the most important and womberful faculties with which we alle enduwed, and we have also given you some conception of the amount we do not know, and from the very nature of things (an never know. This latter, as complared with the former, is immense, but when we come to ansider how wonderful and surprisingly beantiful it all i- we cam only be glad that we are permitterl to know and enjoy as much actual knowledge as we do. I could have confimed mysedt, in thase remarks, to a description and experimental demonstration of some of the beartiful laws of light and vision which science has unraveled out of the eternal mystery, and we conld have 
boasted of the numerous secrets wrested from nature's hidden store-house of fact: by the patient and persistent inquirers in this department of scientific investigation. But true rejence nover exalts itself-is never pufferl up. It is as diligent in seeking out error as it is in finding a new fact. It holds no opinion to be final. The mind of the true seientist is always in a plastic condition, ready to take that form and shape which well-founded data warrant, and is ever willing to change it as the facts rlemand. T'he scientifie gentlemen who have precelled me in this course of lectures have laicl before you knowledge gained from many widely-differing fields of research, but they have never insisterl on the acceptance of a single opinion that was not laid in facts, or was not in strict accordance with well-demonstrated laws. Theories and hypotheses are, it is true, not to be discarded because in the present imperfect state of human knowledge positive ideas are often impossible, but only that one should be accepted which comesnearest to the truth as we know it. Dogmatism and bigotry should find no place in the intellectual make up of the scientific mind. And if I understand aright the purpose of these Saturday scientific lectures, it is not only that you shall become acquainted with the discoveries and advances of modern science-most of which you could learn by a study of books and the reading of the scientific periodicals of the day-but that you might feel and inderstand the attitude of science towards man and his intellectual and moral advancement. The time was when seience was considered the greatest enemy of mankind, when scientists were imprisoned and put to death, and to seek the truth as it was to be found in Nature was considered blasphemy. But the new rat is dawning, and it is the scientist who has opened up the way. The watchword of the hour is Truth! and to whom is this more lear than to the man of science. His whole life is spent in an untiring search after it. The objective point of his every action and thought is the truth. He never fears what effect any new fact may have upon any preconceived opinion, however dear it may be to him. He only asks, is it true? The truth in nature is the idol of 
his atferdions, and he loves it with a love surpassinge that of

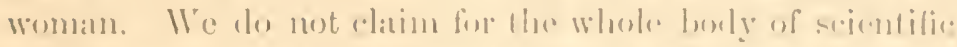
men stels single-minteduese of purpose, but we do clatim

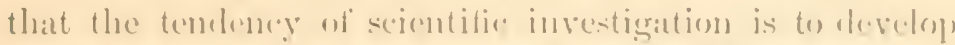

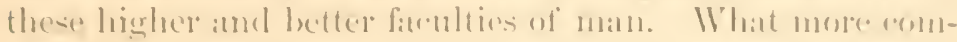

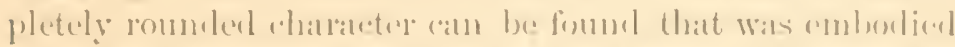
in him whose recent death hatrentried a sense of irreparable loss to the beate of the whole civilized world. In after agen when the worlel make 11 , its roll of great and perfect men, the name of (Charles leobert Darwin will be formel high on the list. Ineliflerent tos the scotls and jeers of his detriketors, he kept his age single to the eternal rerity of Nature. With that he was ("ontent, and in it he fomml his all-sullicient remard.

And when a few dars areo he was calried to his last resting place in the matrolom of Englamel's great deat, and pliced ly the side of lier immortal Newton, science might justly consider that her hone of trimmph haid eome, and that she had won the recognition she clains. That the man whose theory on its fir-t pronmlgation wats emen-idered a lyword of reproalde, should hatre his name mentioned with reverence, and his greatness and worth acknowledger from places which demonmed lum but twenty rears ago, is a -pectitele which is withent a parallel in the history of sciences.

It may he truly with of him, at one of our prets liats said of our belovent Wyman. that it wais his hight purvilene-

.. To fecl my-terion - Nature eser new,

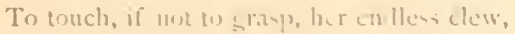

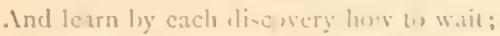
To wolen knowlerl, e and encup the praince Wi-cly (1) teach, becsu-e mork wire (1) learn;

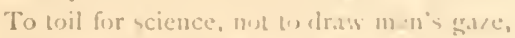
But for her lise of self aluial atcru;

That uch a man c ull tyring from our ilecings, Fans the sul's nubler faith until it hurn." 






RETURN TO the circulation desk of any

University of California Library

or to the

NORTHERN REGIONAL LIBRARY FACILITY BIdg. 400, Richmond Field Station University of California

$\overline{4} \quad$ Richmond, CA 94804.4698

ALL BOOKS MAY BE RECALLED AFTER 7 DAYS

2-month loans may be renewed by calling (415) $642 \cdot 6753$

1-year loans may be recharged by bringing books

- $\quad$ to NRLF

- Renewals and recharges may be made 4 days prior to due date

\section{DUE AS STAMPED BELOW}

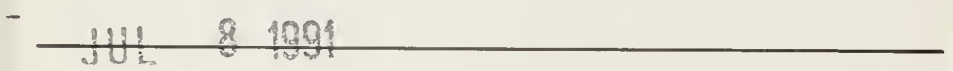

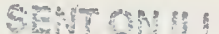

$-$

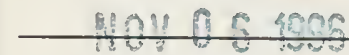

$-$

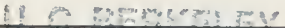

$-$

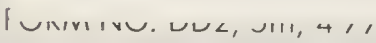



